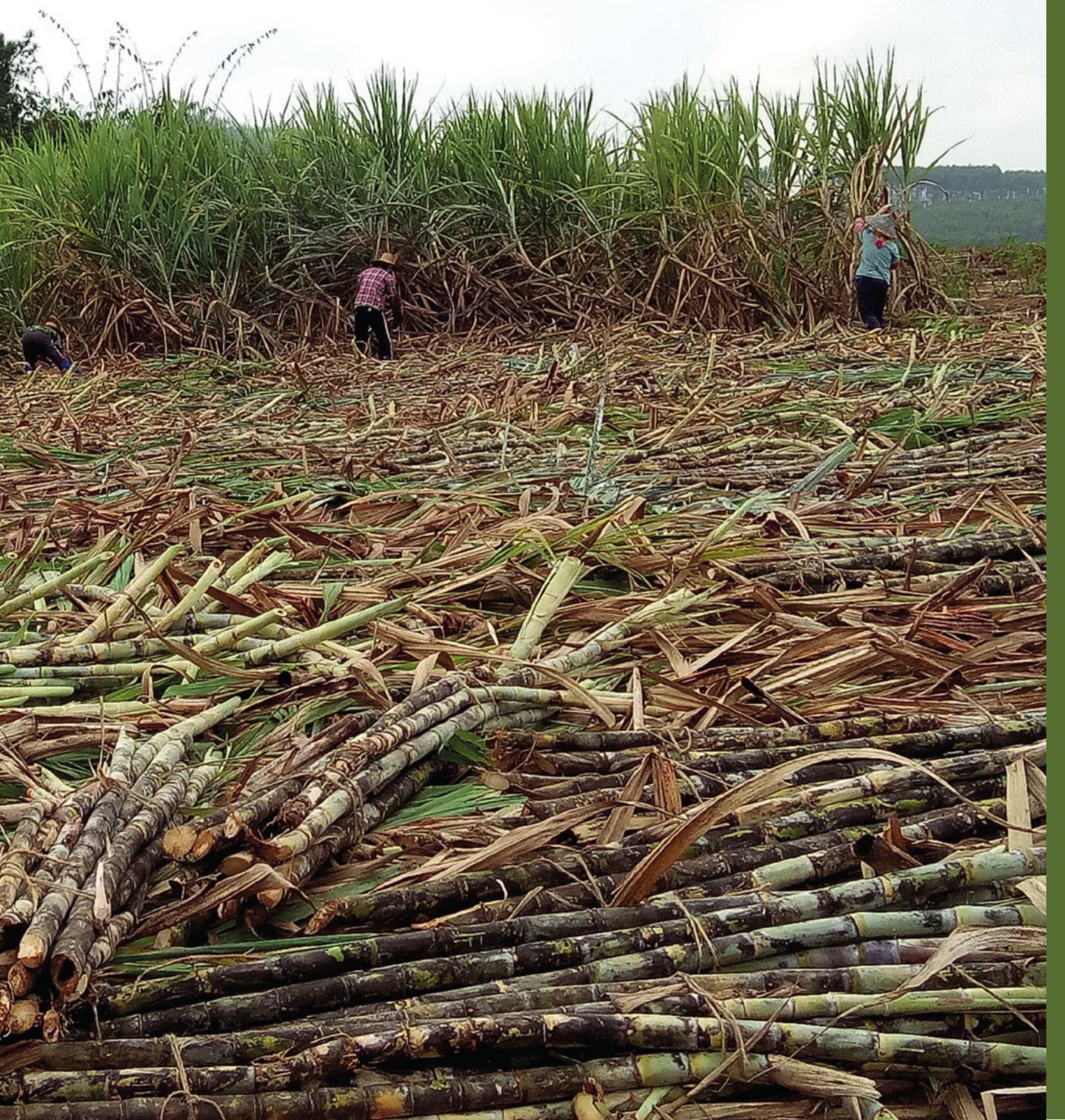

\title{
THE STATE, CAPITAL AND PEASANTRY IN THE AGRARIAN TRANSITION OF CHINA: THE CASE OF GUANGXI SUGARCANE SECTOR
}

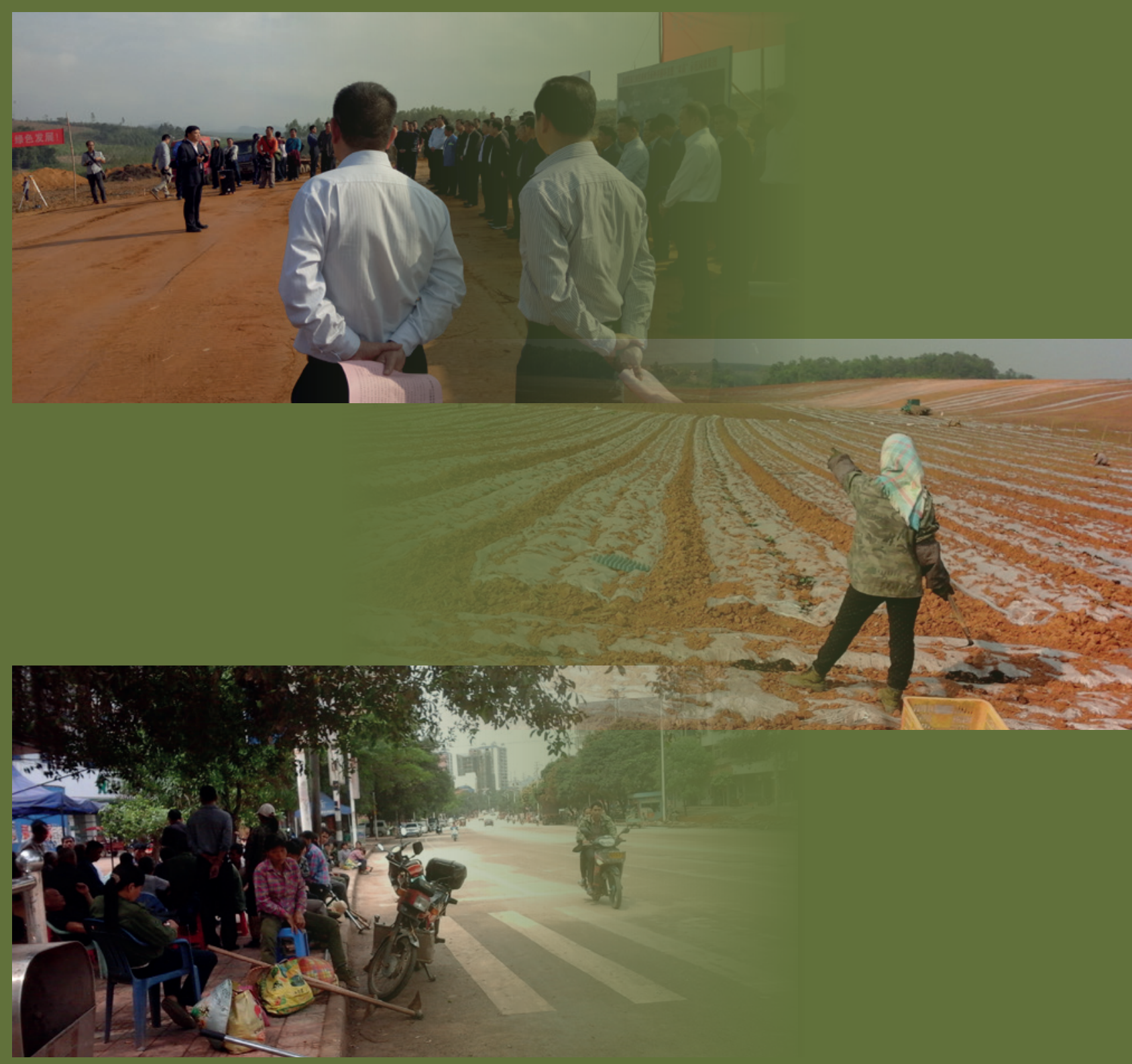

JIN ZHANG 


\section{Propositions}

1. China's oversea expansion is related to market share, not resource extraction (this thesis).

2. Agro-technologies benefit agro-companies but hurt peasants (this thesis).

3. China's food self-sufficiency is economically inefficient.

4. Privatization leads to poverty.

5. Skewed sex ratio has little impact on gender inequality.

6. Doing a $\mathrm{PhD}$ lowers job security.

Propositions belonging to the thesis entitled:

"The State, Capital and Peasantry in the Agrarian Transition of China: the Case of

Guangxi Sugarcane Sector"

Jin Zhang

Wageningen, $8^{\text {th }}$ April 2019 
The State, Capital and Peasantry in the Agrarian Transition of China:

\section{The Case of Guangxi Sugarcane Sector}

Jin Zhang 


\section{Thesis committee}

\section{Promotor}

Prof. Dr J.D. van der Ploeg

Emeritus Professor of Transition Processes in Europe

Wageningen University \& Research

Prof. Dr S.M. Borras

Professor of Rural Development, Environment and Population Studies

International Institute of Social Studies, The Hague

\section{Co-promotors}

Prof. Dr Huifang Wu

Professor of Sociology

China Agricultural University, Beijing, China

\section{Other members}

Prof. Dr W.J.M. Heijman, Wageningen University \& Research

Dr N.B.M. Heerink, Wageningen University \& Research

Prof. Dr Jingzhong Ye, China Agricultural University, Beijing, P.R. China

Dr Heather X.Q. Zhang, University of Leeds, UK

This research was conducted under the auspices of the Wageningen School of Social Sciences. 


\title{
The State, Capital and Peasantry in the Agrarian Transition of China:
}

\section{The Case of Guangxi Sugarcane Sector}

\author{
Jin Zhang
}

\section{Thesis}

submitted in fulfilment of the requirements for the degree of doctor at Wageningen University by the authority of the Rector Magnificus, Prof. Dr A.P.J. Mol, in the presence of the Thesis Committee appointed by the Academic Board to be defended in public on Monday 8 April 2019 at 4 p.m. in the Aula. 
Jin Zhang

The State, Capital and Peasantry in the Agrarian Transition of China: The Case of Guangxi Sugarcane Sector

162 pages.

$\mathrm{PhD}$ thesis, Wageningen University, Wageningen, the Netherlands (2019)

With references, with summary in English

ISBN: 978-94-6343-425-6

DOI: https://doi.org/10.18174/471122 
To my beloved parents

此书献给我挚爱的父亲和母亲 



\section{Table of Contents}

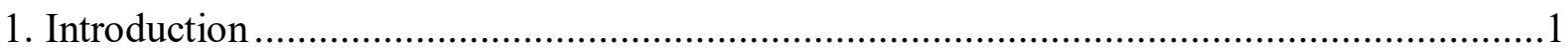

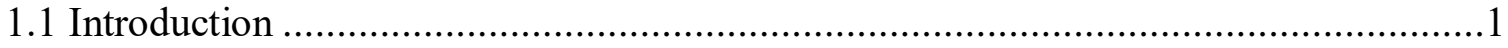

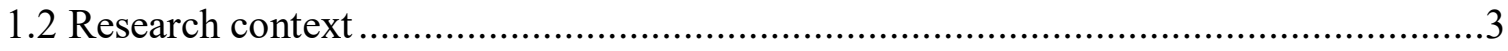

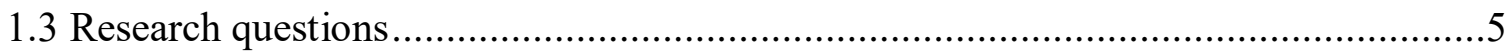

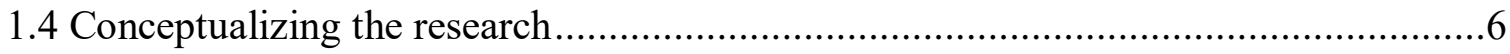

1.5 The analytical framework and methodology ................................................ 10

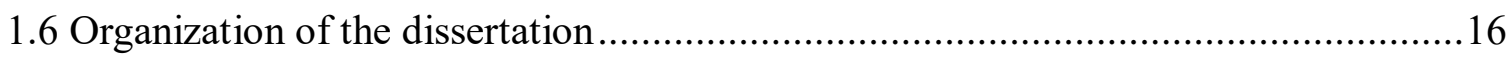

2. Getting the Data Right: Main Trends in China's Agriculture and Food Sector .................19

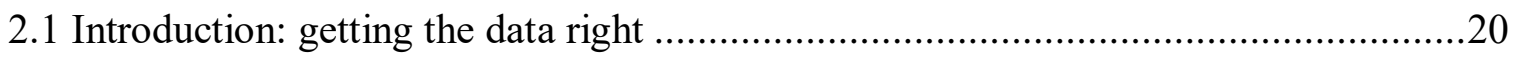

2.2 Agricultural production modalities and the agrarian transition in China ...................22

2.3 Changes in agricultural production factors and China's role in the global food market .28

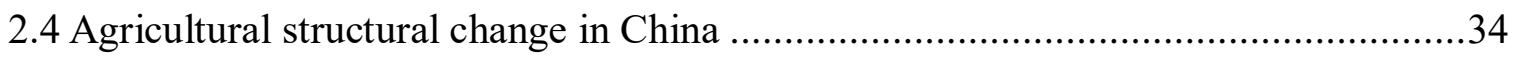

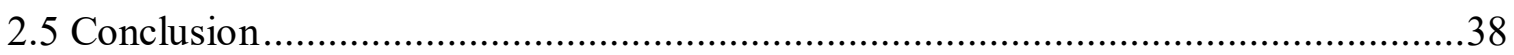

3. Agrarian Change and the Pursuit of Self-supplied Food Security in China ....................39

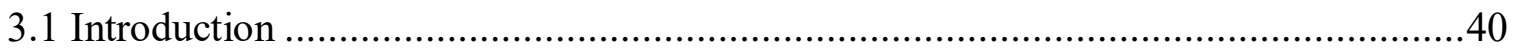

3.2 The new socio-economic challenges to China's food security strategy ....................41

3.3 The historical transition of agriculture and food governance in China: The sugarcane

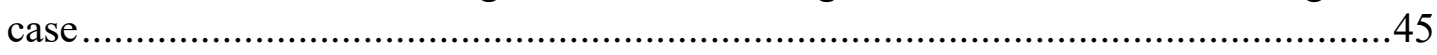

3.4 A reflection on the agricultural production path and agrarian class dynamics...........51

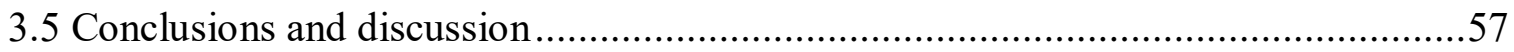

4. Three Strategies of Capital Accumulation in China's sugarcane sector: A Technological-

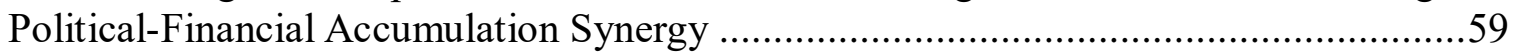

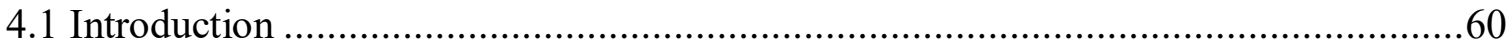

4.2 Recent changes in Dongmen Town's sugarcane production sector..........................62

4.3 Agro-technification: cost-shifting and the redistribution of harvests ......................64 
4.4 Food politicization: the state and agro-food capital nexus......................................68

4.5 Land swindle: land consolidation activities for obtaining agricultural resources .......73

4.6 Conclusions: an accumulation synergy and the food security issue .........................76

5. Repeasantisation despite Labour Commodification: the Case of Seasonal Migrant Cane Cutters in China

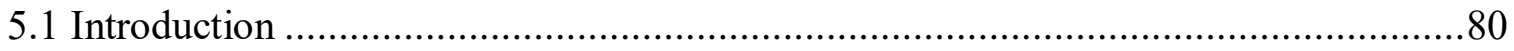

5.2 The history and geography of sugarcane production region and seasonal cane-cutters' migration

5.3 The newly emerged labour market and labour relations in Fusui ............................89

5.4 Interdependency between rural communities and the new threat...........................94

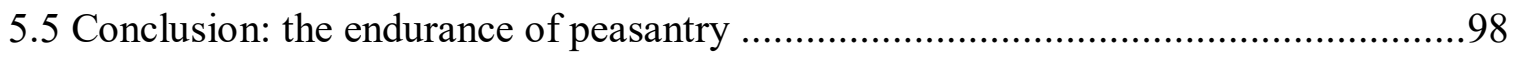

6. Rural land institutions in China: present and future developments............................. 101

6.1 Introduction: the theoretical debate on rural land institutions in China....................102

6.2 Continued and increased land conflicts among individual households ...................108

6.3 Toward corporate farming: the "double constraint" and the economic-environmental crisis

6.4 The trial of agricultural cooperatives: an alternative way under the current land system?

6.5 Conclusion: reflection on the land policy design in China

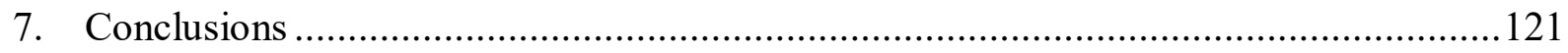

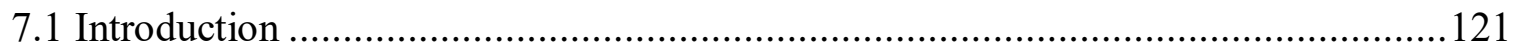

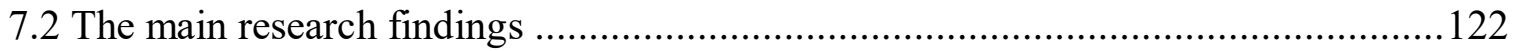

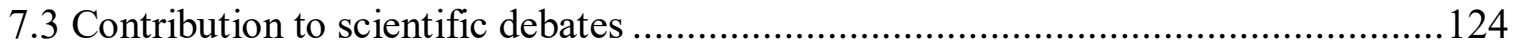

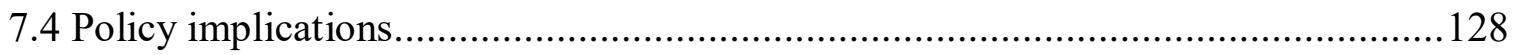

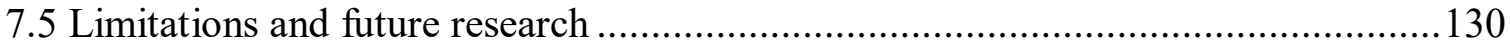

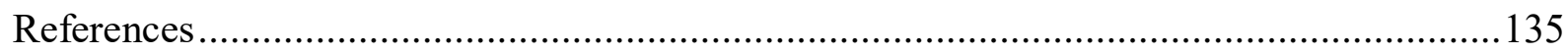

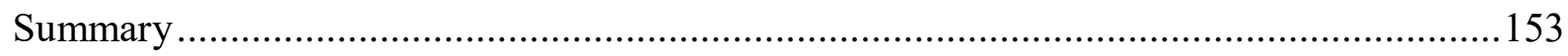




\section{Introduction}

\subsection{Introduction}

China has made great advances in domestic agricultural production and rural income since the Rural Reform in the early 1980s, when the Household Responsibility System - as the institutional foundation for family-based farming - was established to replace the People's Communal System (Van der Ploeg and Ye 2016: 1-4). The gross output value of agriculture, including farming, forestry, animal husbandry and fishery, increased from 192.26 billion CNY to 9699.53 billion CNY between 1980 and 2013. In the farming sector alone, the gross output value rose from 145.41 billion CNY in 1980 to 5149.74 CNY in 2013 (data from National Bureau of Statistics of China). Regarding rural poverty, the official report indicates that the poverty-stricken population in rural China reduced by 700 million from 1978 to 2014, with poverty incidence decreasing by $90.3 \%$ (Zhang 2015).

Nevertheless, new challenges to the domestic food supply have emerged in recent decades. Population growth and a shift to a more "affluent" diet ${ }^{1}$ pose new questions for food demand in terms of amount, quality and variety. Meanwhile, the impacts of the global agricultural products market following China's accession to the WTO on its domestic agricultural production are increasingly visible and deepening. The gap between growth in domestic food demand and constraint of domestic food production is undermining China's food selfsufficiency. As the World Bank reported, 'the food self-sufficiency rate fell below 98 percent in 2010, while that for grain alone fell to 92 percent in 2010 and to 88 percent in 2012 ... soybean imports reached 58.3 million tons in 2012. China has also shifted from being a net exporter of corn in the early 2000s to an importer in 2010, with a net import of 5.2 million tons in 2012 ...imports of sugar, edible oil, dairy products, pork, beef, and mutton have grown to 3.7 million tons, 9.6 million tons, 6.2 million tons (fresh milk), and 0.7 million tons (pork, beef, and mutton), respectively, in 2012' (World Bank 2014: 25). These challenges are pushing the Chinese government to adjust its food security policies.

The macro background of China's agriculture and food sector results from the application of the national strategy of food security. This national strategy is a collection of specific policies for maintaining food self-sufficiency in China. It is very well explained by a media article, which describes how 'China's agricultural sector is supported by a number of policies that are collectively designed to achieve a food self-sufficiency objective. The objective stems from the Chinese Government's view that China's food security is best maintained by meeting its domestic food demand with domestically produced food and minimising its reliance on international markets' (The Poultry Site 2014). Grain self-sufficiency has been a national policy since the Mao era, but food security for a broader range of agricultural products was

\footnotetext{
1 Guo, Mroz and Popkin's study has shown that through the mid-1990s Chinese consumption of meat, edible oils, sugar, eggs, fish and fruit (to a lesser extent) increased while the consumption of cereal and vegetables remained constant. See Guo, Mroz and Popkin's article 'Structural change in the impact of income on food consumption in China, 1989-1993', 2000, Economic Development and Cultural Change.
} 
emphasized as a national strategy for the first time at the Central Economic Working Conference in $2013^{2}$.

Under the new framework of the food security strategy, crops with significance for basic social demands, e.g. grains, sugar crops, oil crops and cotton ${ }^{3}$, are assigned specific production goals. The goals include, but are not limited to, the following: for grains, the total sowing acreage should be maintained at 1.65 billion mu, including 450 million $\mathrm{mu}^{4}$ for paddy production, 330 million mu for wheat production, 500 million mu for maize production, 140 million mu for soy production and 230 million mu for tuber crops. In the case of oil crops (excluding soy), sugar crops and cotton, the expected crops and their related planting acreages are 100 million mu for rape, 70 million mu for peanuts, 21 million mu for sugarcane, 3 million mu for beet and 50 million mu for cotton. Finally, the central government also plans 320 million mu of land for vegetables and 60 million mu for forage crops (Ministry of Agriculture of the PRC 2016). Comparing with the current farmland use for different crops, there is an urge to increase the cultivation acreage of soy, sugar crops and cotton at the expense of crops that do not serve basic dietary needs, such as maize ${ }^{5}$.

The remarkable growth in the gross production value of the Chinese agricultural sector during the past three decades has relied to a large extent on Chinese farmers' shift to high-value farm products, which has been explained by Huang Zongzhi as the 'hidden agricultural revolution' in China. Huang argues that rapid income growth turned the Chinese diet from a previous ratio of 8:1:1 (grains:vegetables:meat) to a current ratio of 4:3:3. The structural change of diet further induced structural change in agricultural production, that is, farmers tend to produce more high-value products, such as vegetables, fruits, meat and aquaculture products. The change to producing high-value farm products has generated more income for farmers in return. Farmers are not keen on low-value products, especially labour-land intensive lowvalue products like soy and oil crops (Huang et al. 2012).

Therefore, the mismatch between what farmers prefer to produce at the micro level and what the state expects to obtain from domestic agricultural production at the macro level is the entry point of this research. From this point, this study tries to explore the agrarian change that is shaped by both top-down state intervention policies and farmers' strategies at the grassroots. With this research target, the study applies rural sociological approaches and agrarian political economic perspectives to examine the dynamic process in the production of one particular crop in China-sugarcane. There are both theoretical and empirical reasons to choose sugarcane as the research objective, which I will explain together with the specific research context on sugarcane production in the next section.

\footnotetext{
2 Takungpao. Food security became a national strategy. Available from: http://finance.takungpao.com/q/2013/1214/2106135.html[in Chinese] [accessed on $5^{\text {th }}$ April 2018]

3 Cotton is not food crop but it is one of the crops with significance for basic social demands.

41 hectare equals $15 \mathrm{mu}$.

5 These crops are not mentioned in this document, but include fruit, herbs, tea and tobacco.
} 


\subsection{Research context}

The largest sugarcane- and sugar-producing region in China is Guangxi province, located in the southwest of China, on the border with Vietnam (see figure 1). The full title of Guangxi province is Guangxi Zhuang Autonomous Region, and it is where $87.8 \%$ of the total Zhuang ethnic people in China live. However, Han people still dominate the population - making up about $62 \%{ }^{6}$ of the residents in Guangxi province.

Although the sugarcane production in Guangxi can be traced back to the early 1900s (Xu 2007), its cultivation has only seen a rapid expansion in the past two decades (see figure 2). The sugarcane expansion that started in the 1990s was the result of a series of policies at that time. One was the "east sugar going west" policy, which was part of the regional development plan by the Chinese government. The south-eastern coastal area (Guangdong province and Fujian province) was earmarked by the central government to develop the manufacturing industry, but the sugar industry is tightly linked with agriculture which demands substantial land and labour. The second was the privatization and contracting out of state-owned industry in the 1990s. The sugar industry was denationalized during this period. This led to a large amount of private capital coming into this industry, which stimulated production capacity. Third was the "foreign capital bring-in" policy that follows the Reform and Open-up. This policy promoted a foreign direct investment rush in the Chinese industries, including the sugar industry (Luo 2009). After fifteen years of fast development, the sugar industry has become one of the main industries of the Guangxi economy ${ }^{7}$. It involves 12 million cane peasants, which are about one third of the rural population in Guangxi (Duan 2016). Guangxi also produces more than two thirds of the total sugar output inside China ${ }^{8}$.

Figure 1. The geographical location of Guangxi province in China and towards the Southeast Asian countries

\footnotetext{
6 Guangxi Government website. http://www.gxzf.gov.cn/zjgx/gxrw/qhrk/201402/t20140211_428687.htm [in Chinese] [accessed on 6th April 2018]

7 National Bureau of Statistics, 2005. 'The main features, problems and development potential of the Guangxi industrial economy', available from: http://www.stats.gov.cn/ztjc/ztfx/fxbg/200506/t20050609_15610.html [in Chinese] [accessed on $1^{\text {st }}$ October 2018]

8 Ministry of Commerce of the People's Republic of China. The sugar yield of Guangxi is over $66 \%$ of the national sugar output. Available from: http://www.mofcom.gov.cn/aarticle/resume/n/201206/20120608186352.html [in Chinese] [accessed on 6 ${ }^{\text {th }}$ April 2018]
} 


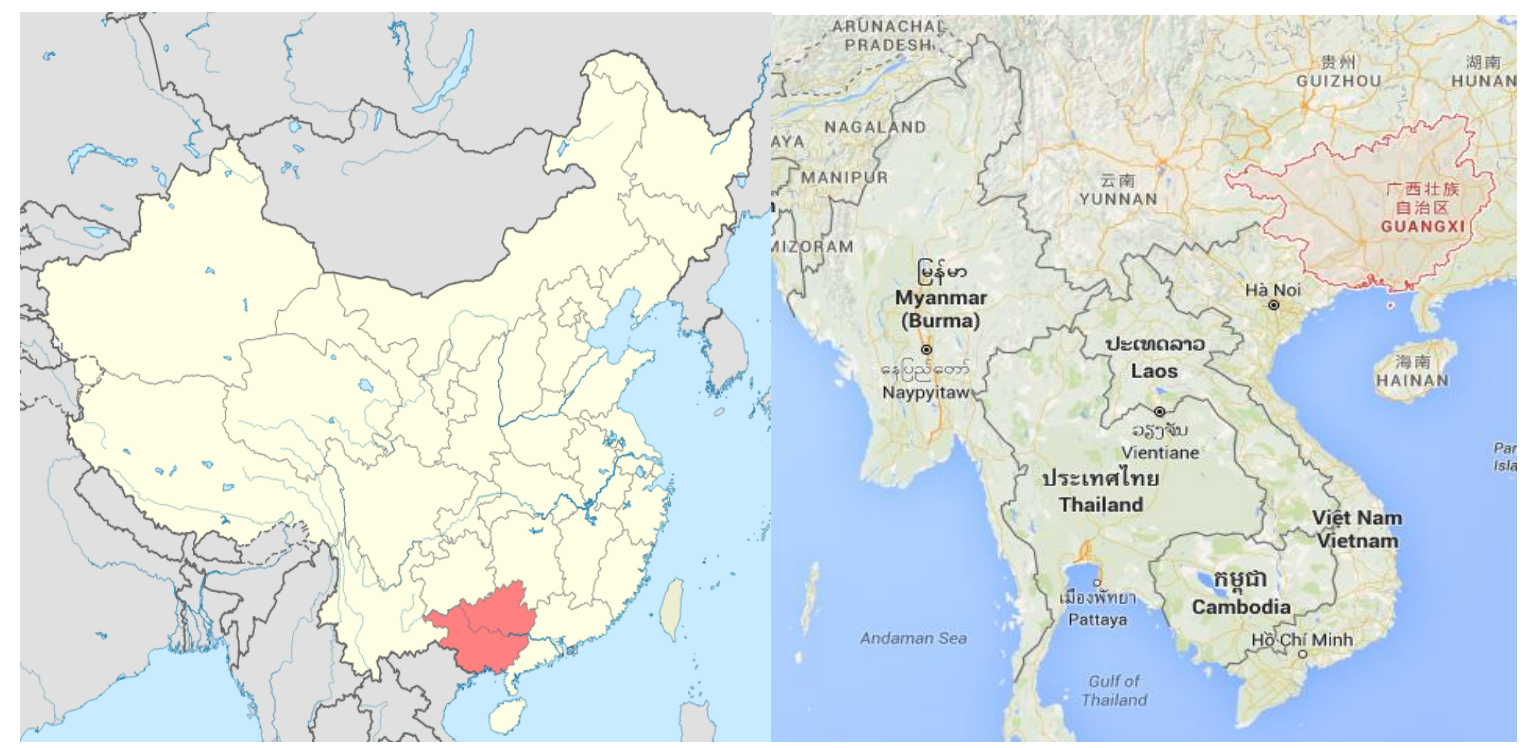

Data source: The map on the right is drawn from Google's picture library; the map on the left is designed by the author using Google Maps.

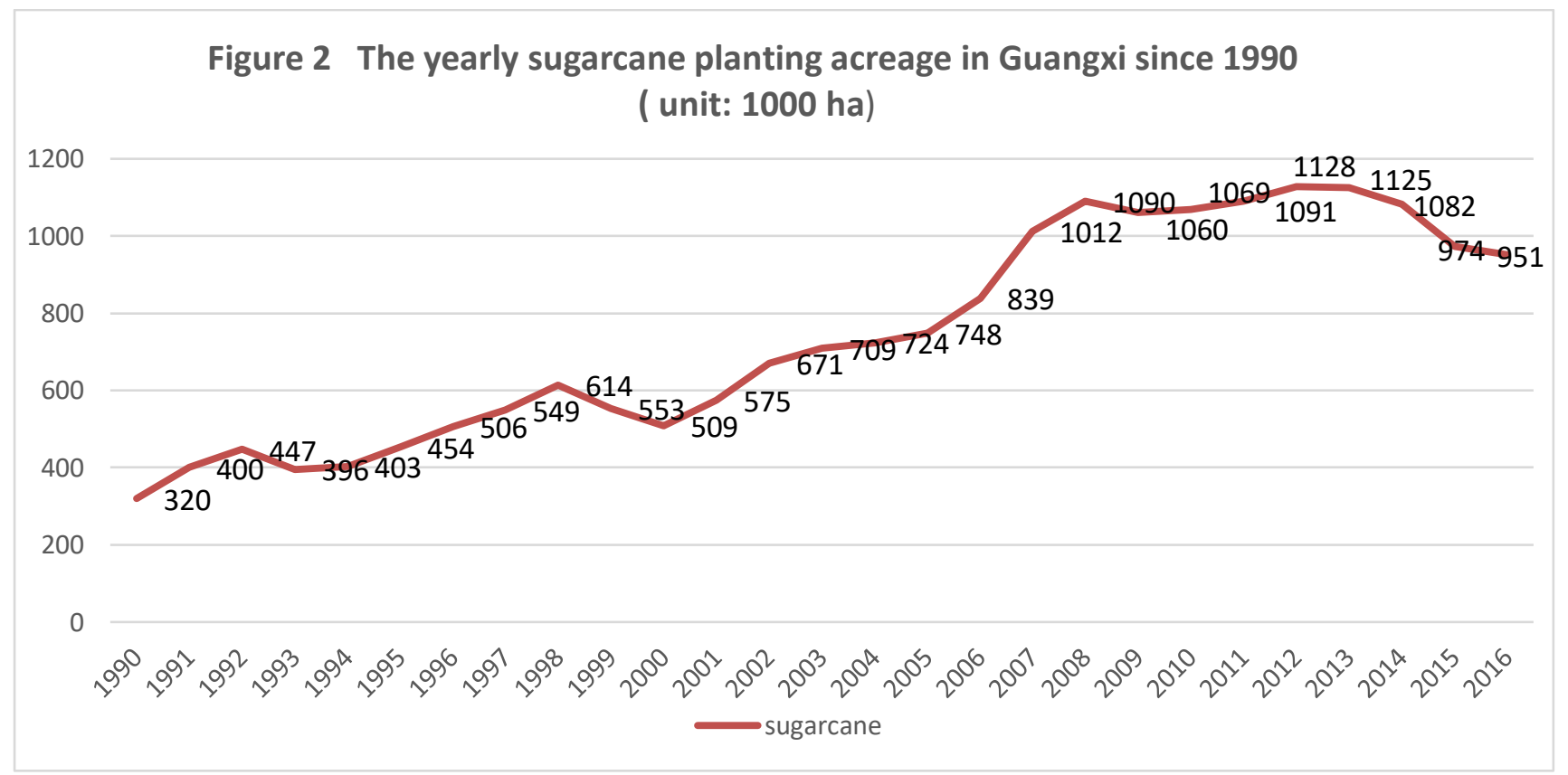

Source: National Bureau of Statistics of People's Republic of China:

http://data.stats.gov.cn/easyquery.htm?cn=E0103

The first dip in sugarcane planting acreage in 2012 can be observed from Figure 2, and this downtrend is slowly continuing. The reduction of sugarcane land has both internal and external causes. The internal cause is that sugarcane is a land-labour intensive crop and the land and labour prices are rising inside China. Thus, farmers in Guangxi province have turned to growing other high-value crops, such as watermelon and citrus fruits. The external cause is that the sugar price in the global market is much lower than the domestic one, which has led 
to increased sugar imports by Chinese food or other sugar-demanding companies. To prevent this downtrend of sugarcane production, and in order to protect the domestic sugar industry, the central government and the Guangxi government together launched a "double-high" sugarcane project. "Double high" means high yield and high sugar content of sugarcane. The main goal of this project is to build a modern sugarcane production zone of a minimum of 5 million mu in Guangxi province by 2020 , to guarantee the raw material supply in the domestic sugar industry (Guangxi Government 2013).

The "double-high" project shows that the central and provincial governments try to maintain sugarcane production in order to protect the domestic sugar industry and ensure domestic sugar supply security. As a result, the recent sugarcane production in Guangxi province has seen state and large capital moving in, large enterprises being set up, and new technologies being brought in. This seems like a top-down, one-sided imposition on sugarcane production with inevitable transition to capitalist agricultural production. However, the farmers in Guangxi have adopted a different strategy to face the sugar price crisis, namely they have tended to stop growing sugarcane.

The discrepancy between the sugarcane project intervention and the trends in farmers' crop preference has brought new dynamics to Guangxi agricultural production. Therefore, this research tries to explore the interactions between the structure and agency in this dynamic transition of the Guangxi sugarcane sector.

\subsection{Research questions}

Based on the research problem outlined above, the central research question in this study is as follows:

How does small-scale peasant farming in the Guangxi sugarcane sector contribute to and get affected by the state's sugar security strategy, and what are the socio-economic implications of the development and expansion of the sugarcane sector on peasant farmers?

Specifically, the thesis tries to explore the five sub-questions:

- What is the current systematic situation of the Chinese agro-food sector, including domestic agricultural production, domestic food consumption and Chinese and global food trade?

- What are the agrarian changes brought about by governmental intervention projects for the pursuit of self-supplied food security in China (the sugar sector as the case study)?

- How does the agro-food capital renew its accumulation strategies under the national sugar security strategy?

- Does the (cross-border, cross-region) migration of cane cutters signify a capitalist process in agriculture or have another socio-structural significance?

- Does the new land usufruct-rights registration policy promote land tenure security in China, and facilitate domestic sugarcane production? 
The first question tries to systematically explore the general trends in China's current agriculture and food sector. Following this overview, the second question examines what the agrarian dynamics are, when the general trends encounter the Chinese government's selfsupplied food strategy. The last three questions are about the dynamics in capital accumulation, labour forms and land institutions, which constitute the classical analytical framework of 'capital-land-labour' in agrarian studies. The purpose of these three questions is to understand whether a transition to classical capitalist agriculture is taking place in the Chinese sugarcane sector.

\subsection{Conceptualizing the research}

The sugarcane boom since the 1990s and the current dip are the result of complex socialeconomic changes in Guangxi's agricultural sector. To understand the transition, this section elaborates on the historical stages of Guangxi's sugarcane production since the 1980s by examining capital sources, land policies, agricultural production modalities, labour migration, and government interventions.

China entered a planned economy era in the 1950s. Like all other economic sectors, the sugar industry was completely controlled by state-owned capital. It was not until 1992 when Deng Xiaoping gave his influential "South China Tour" speech that the "bring-in" strategy (opening the domestic market to foreign capital investments) began to thrive. At the same time, the institutional reform on privatization and contracting out of state-owned industry took place. In Guangxi province, the status of the state-owned sugar industry was interrupted, and many sugar mills were transferred to private capital (both foreign and domestic) from the early 1990s (Luo 2009). Since then, foreign and domestic private capital have both played an important role in the Chinese sugar industry.

Nanning East Asia Sugar Group is the largest foreign investment sugar company inside China. It is a subsidiary company of Thai capital - MitrPhol Sugar Group. MitrPhol Sugar Group is the largest sugar and bioenergy producer in Asia (Guangxi Nanning East Asia Group website). Yangpu Nanhua Sugar Group is the largest sugar producer owned by domestic private capital inside China. During the 1990s and 2000s, the two companies controlled most of China's domestic sugar-related businesses, including sugar manufacturing, sugar refining and sugar marketing. Although some state-owned sugar companies still existed in these decades, state-owned capital in the sugar industry dramatically declined.

From the early 2010s, the domestic sugar industry has been in crisis due to the price competition pressure from the global market and the increased land and labour prices inside China. Having learnt a lesson from the soybean crisis (Yan et al. 2016), the Chinese government has reacted promptly to the potential sugar crisis. As part of the sugar security strategy, state-owned capital was returned to the sugar industry. The two largest state-owned agribusiness companies, COFCO and Bright Food Group, extended their business to the sugar industry, both inside and outside China. As early as 2009 Bright merged with the largest sugar 
company in Yunnan province ${ }^{9}$. Later Bright continued its acquisition strategy in Guangxi province. Compared with Bright, COFCO is more externally-oriented. Since 2011, COFCO bought out Australia's Tully Sugar and the sugar factories of Noble Agri in Brazil.

Meanwhile, it expanded its business in sugar refining and marketing.

The roles of state agribusiness in China have been analysed by Mindi Schneider. She argues that 'although the corporate operations are expanding, the state continues to play a central role in determining the course of market expansion and the destination of profits, sometimes through corporate control' (Schneider 2017: 6). She also shows that state agribusiness influences both national- and global-level developments. On the externally-oriented activities, Hofman and Ho point out that China's offshoring agricultural activities have relevance to its domestic food demands, but this is not the main reason for them. They argue that China's fast economic development has put rising pressure on its domestic natural resources but meanwhile made it a main player in the global economy. With the guidance of the state's 'going global' strategy, many Chinese companies have engaged in offshoring, ranging from energy and mining to finance and real estate. In this research, COFCO's and Bright Food Group's entrance in the sugar industry, both inside and outside China, is considered as one intervention mechanism of the national food security strategy.

Table 1. The main sugar companies in Guangxi, year of foundation and capital property

\begin{tabular}{|c|c|c|}
\hline Main sugar companies in Guangxi & Founded & Capital property \\
\hline Nanning East Asia Sugar Group & 1993 & Foreign capital (Thai) \\
\hline YangpuNanhua Sugar Group & 2002 & Domestic private capital \\
\hline $\begin{array}{l}\text { Guangxi State Farms Sugar } \\
\text { Industrial Group }\end{array}$ & $\begin{array}{l}\text { Existed before the } 1980 \mathrm{~s} \text {, but } \\
\text { mainly developed since } 2000\end{array}$ & State-owned capital \\
\hline Guangxi Feng Sugar Group & 2001 & $\begin{array}{l}\text { 2001-13 domestic private capital } \\
2014 \text { merged by state-owned capital }\end{array}$ \\
\hline Guangxi Nanning Sugar Group & 1999 & State-owned capital \\
\hline $\begin{array}{l}\text { COFCO TunheCo. Ltd } \\
\text { (Guangxi sugar companies) }\end{array}$ & 2010 & State-owned capital \\
\hline Guangxi LaibinEastSugarCo. Ltd & 2003 & $\begin{array}{l}\text { Domestic private capital equals } \\
\text { GuangxiLaibin Government capital }\end{array}$ \\
\hline
\end{tabular}

9 Souhu Business news. Bright acquired Guangxi Feng Sugar Group, Yingmao Sugar is going to an IPO. Available from: http://business.sohu.com/20141204/n406637694.shtml [in Chinese] [accessed on $10^{\text {th }}$ April 2018] 
Table 2. State-owned agribusinesses and their expansion in the sugar business in recent years

\begin{tabular}{|c|l|l|}
\hline $\begin{array}{c}\text { State-owned } \\
\text { Agribusiness }\end{array}$ & Time & Expansion activities (acquisition or new-built) \\
\hline \multirow{4}{*}{ COFCO } & 2011 & Australian Tully Sugar \\
\cline { 2 - 3 } & 2014 & Sugar mills of Noble Agri. in Brazil \\
\cline { 2 - 3 } & 2014 & $\begin{array}{l}\text { China National Sugar \& Alcohol Group (the largest sugar } \\
\text { seling and marketing company in China) }\end{array}$ \\
\cline { 2 - 4 } Bright Food Group & 2014 & $\begin{array}{l}\text { Caofeidian Sugar Refinery (large sugar refinery for } \\
\text { imported raw sugar) } \\
\text { Yingmao Sugar Industry Company (the largest sugar } \\
\text { company in Yunnan province) }\end{array}$ \\
\cline { 2 - 3 } & 2009 & Guangxi Feng Sugar Group \\
\cline { 2 - 3 } & 2013 & Yunnan Yingmao Sugar Refinery Project \\
\hline
\end{tabular}

Land policies have changed across the whole of rural China since the 1980s, including Guangxi province. The rural reform set up the household responsibility system (HRS) as the basic land institution in rural China. Based on the HRS, small household farming became the dominant mode in Chinese agricultural production, including sugarcane production. Since 2008 land transfer became popular in the land policy discourse as well as in practice (Ye 2015). The direct impact of land transfer is the increase of large-scale farms based on land concentration. In the sugarcane sector, the number of small household cane producers declined, while corporate plantations and entrepreneurial farming emerged in the Guangxi sugarcane production.

The change in farming modalities was also facilitated by the change in the government strategies on sugarcane production. In the early 2000 s the "cane-area system" was introduced by the Guangxi government. The basic idea of this "cane-area system" is to make sure that individual small households produce sugarcane, and that sugar companies purchase sugarcane. But due to the sugar price crisis since 2012, a substantial amount of farmland in Guangxi province has been converted to growing watermelon, eucalyptus and banana (Borras et al. 2018). Therefore, from 2013 the "double-high" sugarcane project was introduced as a solution to confront the situation of continuous reduction of sugarcane land. This project accelerated the pace of land transfer and facilitated the emergence of corporate farming in the sugarcane production zone, since large-scale farms for sugarcane production can get subsidized by the government (Guangxi Government 2013).

Labour migration is also a key issue regarding the agrarian change in the Guangxi sugarcane sector. The rapid wage increases in urban manufacturing and service industries attracts young rural labourers away from farming, which causes a relative labour shortage during the cane 
harvest season. However, the labour-shortage problem is quickly solved by the cheaper labour supply from Vietnam ${ }^{10}$, as well as from the more remote areas of neighbouring provinces inside China, such as the Yunnan and Guizhou rural areas ${ }^{11}$. But with the introduction of the "double-high" project, large sugarcane plantations were set up through land transfer in some villages. When the village land was concentrated in the large plantations, the problem shifted from labour shortage to labour surplus. Since the plantations promised to give priority to the villagers whose land was leased to them, the previous cane-cutting peasants are now struggling to make their livelihoods.

The conceptual framework for the analysis of the agro-food sector in China is based on the food regime approach by Friedmann and McMichael. They argue that a food regime is the analysis that 'links international relations of food production and consumption to forms of accumulation broadly distinguishing periods of capital transformation' (Friedmann and McMichael 1989: 95). There are two characteristics that distinguish the conceptualisation in this research from a food regime analysis: first, food regime analysis holds a global perspective while this research mainly focuses on China; second, food regime analysis is a historical analysis of capitalism, but Chinese history, especially in terms of agricultural production, cannot be simply considered as capitalism. Therefore, this research uses the term 'periodisation of agrarian change' instead of 'food regime' to refer to the conceptual framework of the Chinese agro-food sector since rural reform.

The preliminary description of the research context can be condensed into a periodisation of agrarian change in Guangxi sugarcane sector. Each period has a different political and economic context for agriculture production, ranging from government intervention, agricultural capital and land policies to production modes and labour dynamics. I summarize the conceptual analysis in table 3 .

Table 3. The periodisation of Guangxi sugarcane production since the Rural Reform

\begin{tabular}{|l|l|l|l|}
\hline Periodisation & Post-rural reform & Fiscal reform & Post-WTO \\
\hline Nationwide standard & $1984-1993$ & $1994-2002$ & 2003 \\
\hline $\begin{array}{l}\text { Specific to Guangxi's } \\
\text { sugarcane sector }\end{array}$ & $1984-1993$ & $1994-2012$ & $2012-$ \\
\hline $\begin{array}{l}\text { State strategy for } \\
\text { sugar supply security }\end{array}$ & $\begin{array}{l}\text { "Grain-sugarcane } \\
\text { barter policy" } \\
\text { (focus on domestic } \\
\text { production) }\end{array}$ & $\begin{array}{l}\text { "east sugar going } \\
\text { west" policy } \\
\text { (focus on domestic } \\
\text { production) }\end{array}$ & $\begin{array}{l}\text { State-owned } \\
\text { agribusiness } \\
\text { companies "go-out" } \\
\text { strategy (turn to using } \\
\text { global resource); } \\
\text { The government(s) } \\
\text { ensure a minimum }\end{array}$ \\
\hline
\end{tabular}

10 Yunnan Sugar website. 2012. Border Vietnamese actively help border Chinese cut sugarcane. Available from: http://www.ynsugar.com/Article/ZXZX/chanqu/201203/33939.html [in Chinese] [accessed on 11 ${ }^{\text {th }}$ April 2018]

11 Fangchenggang Daily. 2015. Cutting sugarcane. Available from: http://www.fcgsnews.com/news/lswh/20152-16/65887.shtml [in Chinese] [accessed on $11^{\text {th }}$ April 2018] 


\begin{tabular}{|c|c|c|c|}
\hline & & & $\begin{array}{l}\text { level of domestic } \\
\text { production }\end{array}$ \\
\hline $\begin{array}{l}\text { Capital in Guangxi's } \\
\text { sugar industry }\end{array}$ & State-owned capital & $\begin{array}{l}\text { Mainly foreign and } \\
\text { domestic private } \\
\text { capital; } \\
\text { Little state-owned } \\
\text { capital }\end{array}$ & $\begin{array}{l}\text { Foreign capital } \\
\text { remains; } \\
\text { Domestic private } \\
\text { capital shrinks; } \\
\text { Fast expansion of } \\
\text { state-owned capital. }\end{array}$ \\
\hline $\begin{array}{l}\text { Government } \\
\text { intervention }\end{array}$ & $\begin{array}{l}\text { Award grain for } \\
\text { sugarcane }\end{array}$ & "Cane-area system" & $\begin{array}{l}\text { "Double-high" } \\
\text { sugarcane project }\end{array}$ \\
\hline Land institution & $\begin{array}{l}\text { Household } \\
\text { responsibility system }\end{array}$ & $\begin{array}{l}\text { Household } \\
\text { responsibility system }\end{array}$ & Land transfer \\
\hline Production mode & $\begin{array}{l}\text { Small-scale household } \\
\text { farming }\end{array}$ & $\begin{array}{l}\text { Small-scale household } \\
\text { farming }\end{array}$ & $\begin{array}{l}\text { Corporate plantations } \\
\text { and entrepreneurial } \\
\text { farms }\end{array}$ \\
\hline Labour issue & Family labour & $\begin{array}{l}\text { Rural-urban migration } \\
\rightarrow \text { left-behind labour } \\
\text { and cross-border } \\
\text { labour migration }\end{array}$ & $\begin{array}{l}\text { Decrease in labour } \\
\text { demand; } \\
\text { Livelihood crisis for } \\
\text { previous cane-cutters }\end{array}$ \\
\hline Small-scale peasants & $\begin{array}{l}\text { Prefer to produce } \\
\text { grains }\end{array}$ & $\begin{array}{l}\text { Prefer to produce } \\
\text { sugarcane }\end{array}$ & $\begin{array}{l}\text { Prefer to produce } \\
\text { fruit, eucalyptus, etc. }\end{array}$ \\
\hline
\end{tabular}

Gong from one period to the other as indicated in table 3, there are shifts at different levels and regarding different dimensions. These shifts together refer to the change from one regime to another regime. And although these shits are interacting with the global economy, their gravitational centre clearly resides in China. In the chapters to come, I will especially discuss the post-WTO period with the focus on land, labour and capital, and how they are institutionally tied together.

\subsection{The analytical framework and methodology}

Central to this research is the discrepancy between the state's sugar security strategy and the changed crop preference among small farmers in Guangxi province. The aim of this research is to explore agrarian change resulting from two contradictory yet interlocking processes. They are the control over agricultural production by the state and the peasants fighting for autonomy. The analytical framework of this research can be seen below (figure 3). The driving forces are the national food security strategy that is manifested by top-down interventions, and the small farmers' strategies that represent the bottom-up influences in agricultural production. The interaction between the two processes leads to agrarian change through multiple specific mechanisms, including capital accumulation, land policies, farming 
modalities, labour forms and local-government interventions. Finally, these mechanisms in agrarian change have different impacts on national food security, agricultural production and rural livelihoods, which correspond to the sannong issues in China: 农业, 农民, 农村.

Next to the important theoretical issues, this research also has methodological advancements. It deals with the analytical approaches that are usually considered as contradictory with each other, they are: micro analysis versus macro analysis, actor-oriented analysis versus structural analysis, rural sociological approach versus agrarian political economic perspective. Through this research, I will argue that one does not exceed the other, they are complementary in rural studies.

Figure 3. The analytical framework of this research

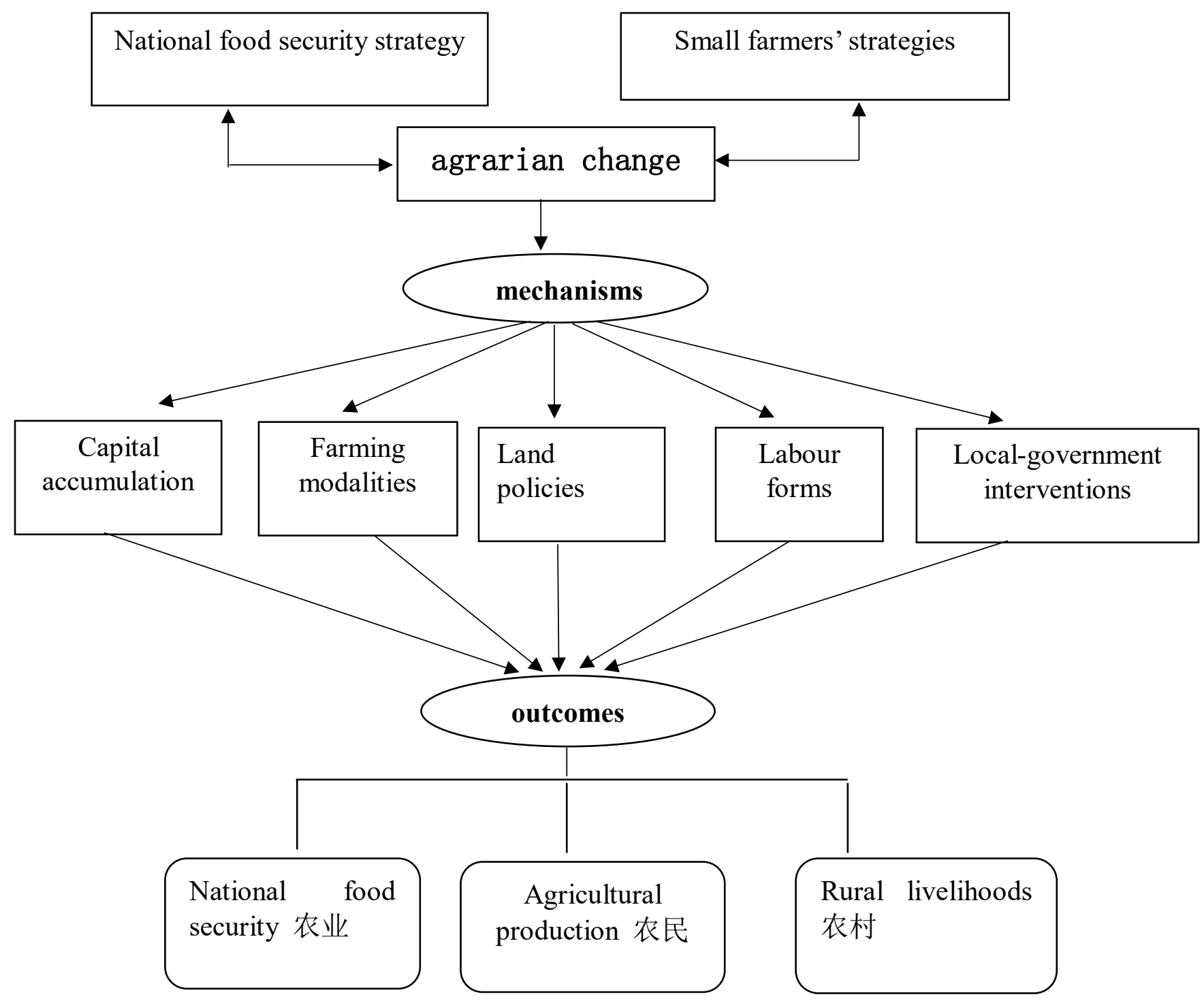

While the analytical framework has shown the systematic relations of the research topics that are critical to the research questions, the methodology of this research further indicates what types of data are needed to unravel these questions. As Gregory argues, 'Methodology brings 
together and links the underlying philosophical and conceptual bases of a study with appropriate techniques... Methodology is a meta-level issue about fitting techniques to research questions, rather than simply learning a method' (Gregory et al. 2009: 457). According to the research questions, there are two main parts of data collection. The broad socio-economic context of the agro-food production (especially the sugar industry) in China requires a systematic analysis using secondary data, including national policies, government documents, statistical reports, media articles/news, company data, etc. The dynamic situation of the sugarcane production and rural livelihoods in Guangxi province requires first-hand fieldwork data. Given the characteristics of this research, I chose to do a case study with social-anthropological methods, e.g. in-depth interviews, group interviews, oral history, participatory observation and repeated visits.

Figure 4. The methodology schema of this research

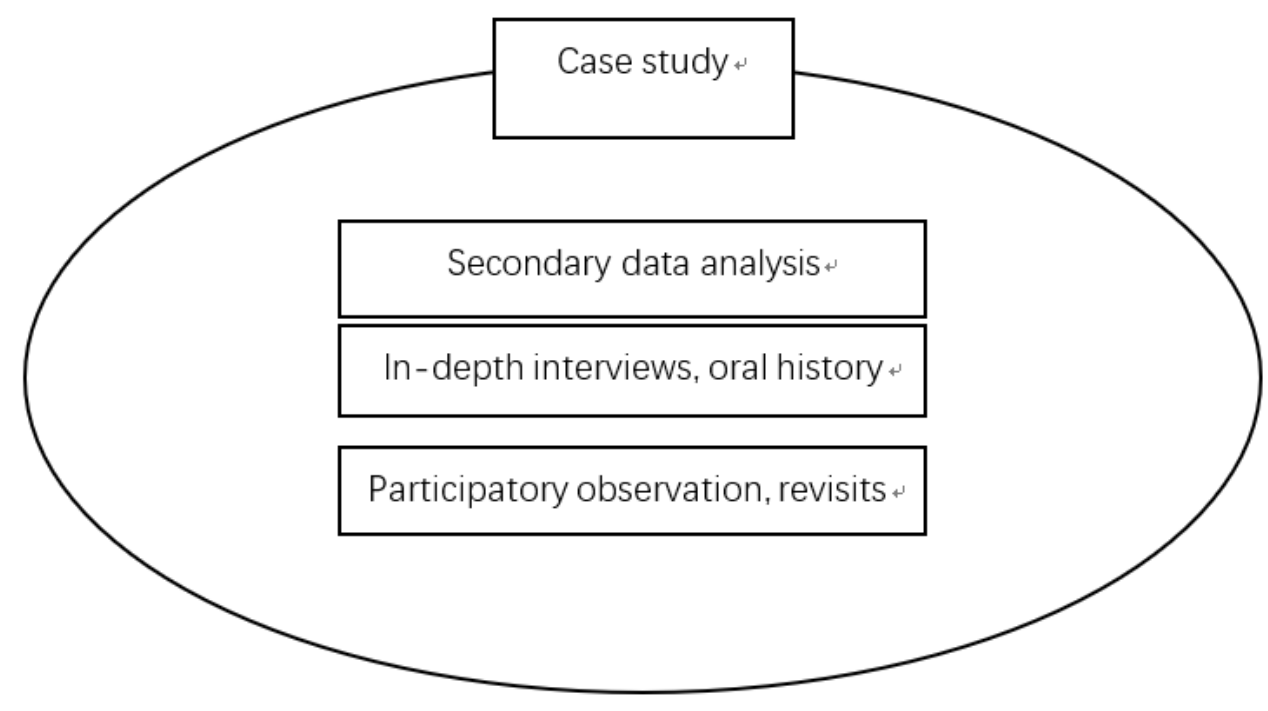

\section{Case Study}

This study applies a case study to understand the dynamics in the Guangxi sugarcane sector. According to Ragin, 'boundaries around places and time periods define cases' (Ragin and Becker 1992: 5). Almost all the cases in social studies have their theoretical or methodological implications. "Cases are "made" by invoking theories, whether implicitly or explicitly, for justification or illumination, in advance of the research process or as its result' (Ragin and Becker 1992: 121). In this study, the case is a rural town named Dongmen in the main sugarcane production zone of Guangxi province.

Dongmen is a typical rural town in the main sugarcane production zone of Guangxi, where local peasants' livelihoods heavily rely on growing sugarcane. There are 15 administrative villages and 47,000 residents inside Dongmen. It is under the jurisdiction of Fusui county in Guangxi province, located in the border area between Southwest China and North Vietnam. Sugar manufacturing is the main industry in Fusui county and therefore it is also the main 
beneficiary of governmental fiscal revenues. The total farming land ${ }^{12}$ in Dongmen town is around 200,000 mu, of which $189,000 \mathrm{mu}$ is cultivated for sugarcane.

Dongmen-Nanhua Sugar Company - one of the many affiliated companies of Nanhua Sugar Industry Group - is located in Dongmen town. This company has played an important role in the local sugarcane production in the past decades and recently it also fully engaged in the implementation of the government's "double-high" sugarcane project. Furthermore, some private urban capital has flown into sugarcane production in the town. Large-scale land transfer and land concentration have been achieved and several sugarcane plantations have been set up, owned by the farming companies. Therefore, the dynamics of large outsidecapital investment in sugarcane production in Dongmen challenge its tradition of smallhousehold sugarcane production, which makes it a good research spot to unravel the research questions.

Figure 5. The geographic location of Dongmen town

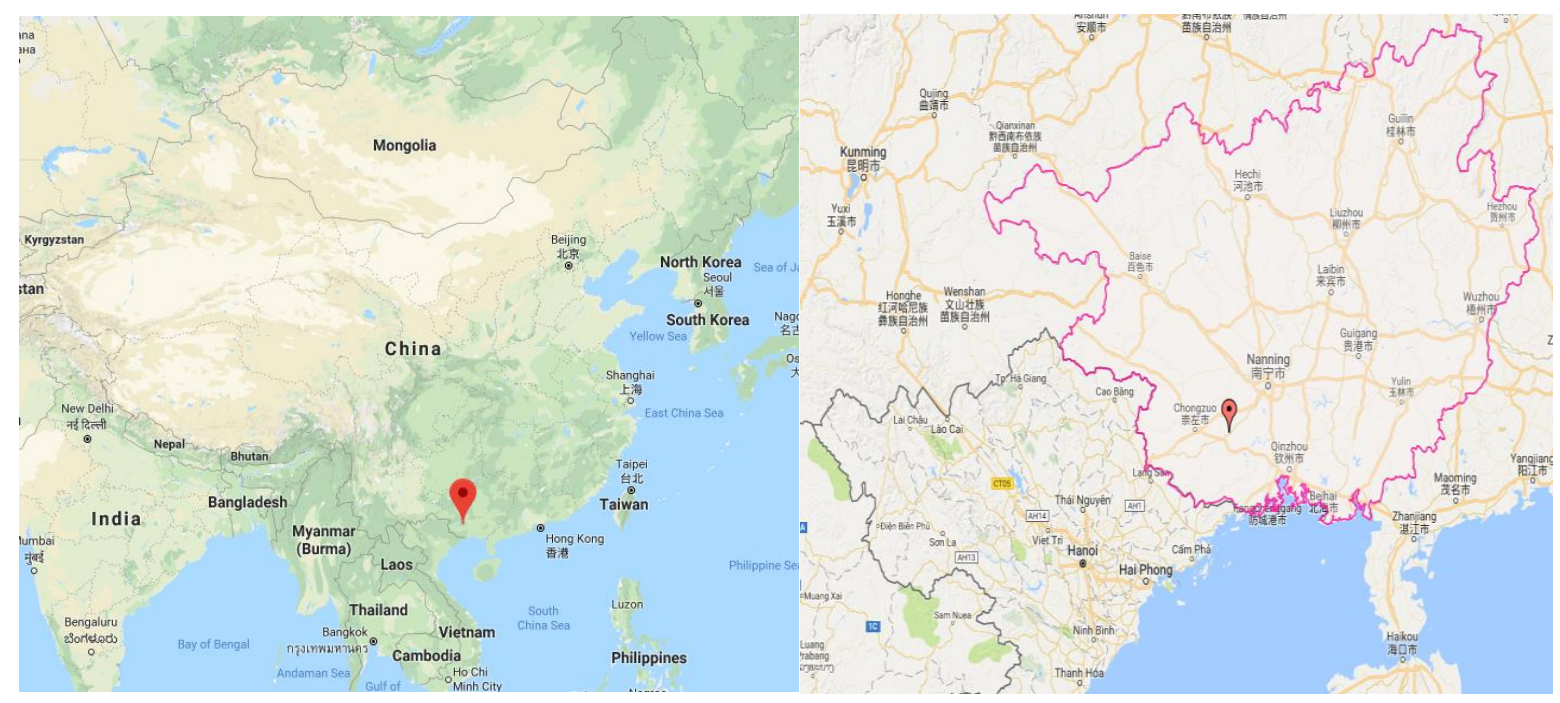

\section{Secondary Data Analysis}

As the research questions include the macro-level analysis of the political-economic contexts and the historical changes of sugar industry development, this research requires collecting and analysing secondary data, including national policies regarding agriculture and food, relevant research and media reports, and statistical data collected by local governments.

'Secondary data can include any data that are examined to answer a research question other than the questions for which the data were initially collected' (Vartanian 2010: 3). Below I list the types of secondary information that need to be collected and analysed (table 4).

\footnotetext{
12 In China, rural land is categorized by and regulated for different usages, e.g. farmland, forest land, construction land, etc. Legally, forest land cannot be used for farming, and vice versa.
} 
Table 4. The questions and the required secondary data

\begin{tabular}{|c|c|c|c|}
\hline $\begin{array}{l}\text { General } \\
\text { question }\end{array}$ & Sub-questions & Information & Source \\
\hline \multirow{6}{*}{$\begin{array}{l}\text { What are the } \\
\text { changes in } \\
\text { sugarcane } \\
\text { production in } \\
\text { Guangxi } \\
\text { province since } \\
\text { the Rural } \\
\text { Reform, and } \\
\text { why? }\end{array}$} & $\begin{array}{l}\text { The global } \\
\text { context? }\end{array}$ & $\begin{array}{l}\text { China's sugar trade in the } \\
\text { global market }\end{array}$ & $\begin{array}{l}\text { Literature and statistical data on Chinese } \\
\text { and global sugar trade after China's } \\
\text { accession to the WTO }\end{array}$ \\
\hline & \multirow{3}{*}{$\begin{array}{l}\text { The national } \\
\text { political- } \\
\text { economic } \\
\text { context? }\end{array}$} & $\begin{array}{l}\text { The influence of China's } \\
\text { development strategy on the } \\
\text { sugar industry }\end{array}$ & $\begin{array}{l}\text { China's national "bring-in" and "go-out" } \\
\text { economic policies, regional development } \\
\text { plans, and other governmental documents. }\end{array}$ \\
\hline & & $\begin{array}{l}\text { The increased sugar } \\
\text { demand in China }\end{array}$ & Government reports and statistical data \\
\hline & & $\begin{array}{l}\text { China's sugar supply } \\
\text { security strategies }\end{array}$ & $\begin{array}{l}\text { Grain-sugarcane barter policy in the 1980s; } \\
\text { "East sugar going-west" policy; } \\
\text { State-owned agribusinesses' "go-out" } \\
\text { strategy }\end{array}$ \\
\hline & \multirow{2}{*}{$\begin{array}{l}\text { The local } \\
\text { context? }\end{array}$} & $\begin{array}{l}\text { The role of local } \\
\text { government }\end{array}$ & $\begin{array}{l}\text { Fiscal reform and the administrative } \\
\text { institutional system in China }\end{array}$ \\
\hline & & $\begin{array}{l}\text { The transition of crop } \\
\text { planting in Guangxi }\end{array}$ & $\begin{array}{l}\text { Documents on land use and management } \\
\text { over time from the local government }\end{array}$ \\
\hline
\end{tabular}

In-depth interviews

This research focuses on the socio-economic relations and changes of rural production under the new agro-food policies in China. It requires profound understanding of the interests of and relations between different participants involved in the sugarcane sector. Therefore, qualitative data is more suitable for the research purpose. For qualitative data, in-depth interviews are demanded. 'In-depth interviews are interviews in which participants are encouraged and prompted to talk in depth about the topic under investigation without the researcher's use of predetermined, focused, short-answer questions' (Given 2008: 422).

Regarding the dynamics of the five research objectives that indicate agrarian change in China and the implications on peasants, this research involved a collection of semi-structured interviews, including individual interviews and focus group discussions. The individual interviews have three categories of informants: peasants, government officials and the managers of sugar companies. Focus group discussions have been conducted, especially with peasants, because they allow researchers 'to learn about participants' perspectives by listening to their conversations [which] makes focus groups especially useful for hearing from groups whose voices are often marginalized within the larger society" (Given 2008: 352). Furthermore, focus group discussions can sometimes reveal direct conflicting perspectives and lead researchers to study some unexpected topics. The plan for the research sample is summarized in table 5 . 
Table 5. List of interviewees and the specific research methods

\begin{tabular}{|c|c|c|c|}
\hline Respondents & Categories & Semi-structured interviews & $\begin{array}{l}\text { Focus group } \\
\text { discussions }\end{array}$ \\
\hline \multirow{3}{*}{$\begin{array}{l}\text { Government } \\
\text { officials }\end{array}$} & Province & $\begin{array}{l}\text { Agricultural Bureau: } 1 \\
\text { Land Resources Bureau: } 1 \\
\text { Industry and Business Administration } \\
\text { Bureau: } 1\end{array}$ & -- \\
\hline & County & $\begin{array}{l}\text { Agricultural Bureau: } 1 \\
\text { Land Resource Bureau: } 1 \\
\text { Industry and Business Administration } \\
\text { Bureau: } 1\end{array}$ & -- \\
\hline & Township & $\begin{array}{l}\text { Agricultural Bureau: } 1 \\
\text { Land Resource Bureau: } 1\end{array}$ & \\
\hline $\begin{array}{l}\text { Sugar } \\
\text { Companies } \\
\text { and } \\
\text { Sugarcane } \\
\text { plantation }\end{array}$ & Fusui County & $\begin{array}{l}\text { East Asia Sugar Company: } 1 \\
\text { Nanhua Sugar Company: } 1 \\
\text { COFCO Tunhe Co. Ltd.: } 1\end{array}$ & -- \\
\hline \multirow[t]{2}{*}{$\begin{array}{l}\text { Village } \\
\text { informants }\end{array}$} & Village cadres & $4-7$ & -- \\
\hline & Peasantry & $\begin{array}{l}\text { Cane farmers: } 15 \text { in each key village } \\
\text { Migrant cane cutters: } 15-20 \text { in total }\end{array}$ & $\begin{array}{l}5 \text { groups of migrant } \\
\text { cane cutters; } \\
10 \text { groups of cane } \\
\text { farmers (can be divided } \\
\text { according to gender, } \\
\text { age, and farming } \\
\text { acreage); }\end{array}$ \\
\hline $\begin{array}{l}\text { Other } \\
\text { relevant } \\
\text { informants }\end{array}$ & $\begin{array}{l}\text { Middle-men } \\
\text { between cane } \\
\text { peasants and } \\
\text { sugarcane buyers; } \\
\text { Banana or other } \\
\text { cash-crop investors; } \\
\text { Workers in the local } \\
\text { sugar factories }\end{array}$ & $\begin{array}{l}\text { Uncounted. But through the fieldwork, } \\
\text { it turned out that this group of } \\
\text { informants provided much useful } \\
\text { information. }\end{array}$ & -- \\
\hline
\end{tabular}

Participatory observation and repeated visits 
Participatory observation allows researchers to understand nonverbal attitudes and unspoken activities. 'If the 'interview society' 13 is still the dominant societal model, the recent sudden increase of ethnography can be explained with the hypothesis that we are entering into an 'observation society', a society in which observing (as interviewing) has become a fundamental activity, and watching and scrutinizing are becoming important cognitive modes alongside the others, like listening, feeling, hearing and eavesdropping, typical of the 'interview society', (Gobo 2011: 25). Most of the time, social relations, changes of peasant farming and the activities of sugar companies cannot be comprehended through face-to-face interviews due to interviewees' unwillingness to discuss these issues publically or just everyday life in rural societies. Thus, the research analyses the social structure and dynamics through participatory observation. It is an efficient way to enrich the empirical observation in sociological studies.

Understanding the socio-economic changes in rural society requires long-term fieldwork. However, sometimes one-time, long period fieldwork is not efficient, especially in cases where social processes or events are ongoing. Therefore, I divided my fieldwork into three periods between 2014 and 2017, and each time I spent 2-3 months in the field. The fieldwork lasted about 8 months in total.

\subsection{Organization of the dissertation}

The thesis comprises seven chapters. Following the introduction, there will be five chapters respectively answering the five research questions and a general discussion as the final chapter. The interrelations of the five research questions have been discussed in the third section, so I will not repeat here. The following chapters are:

Chapter 2 discusses the main trends in China's agriculture and food sector: the multiple farming modes and their inter-relations; the international food trade between China and the global market; the structural change in diet and the land-labour price change. The chapter tries to understand the influence of these changes on the agricultural structure in China.

Chapter 3 explores agrarian change brought about by the state's pursuit of self-supplied food security. It first systematically explains the causes of the Chinese government's concern around the national food security issue. By looking into the sugarcane project, it shows the implications of the current food security strategy on agricultural production, peasant livelihood and rural society.

Chapter 4 presents the accumulation strategies of agro-food capital under the national sugar security strategy. It examines three parts: the new technologies in cane farming and cane processing sectors; the interaction between sugar companies and the Chinese government to

13 Interview society suggests 'a research program transcending the specifics of interviewing as a research method, or of narrative analysis, to focus attention on biographical work in general' (Silverman and Atkinson 1997: 306) 
restructure domestic sugarcane production; and the speculative activities on land concentration in the context of "double-high" sugarcane project.

Chapter 5 deals with the issue of seasonal migrant cane cutters in the Guangxi sugarcane production region. It analyses the shift of geographic regions of cane cutters, the process of different labour forms, and the interdependent relation between cane farmers and cane cutters.

Chapter 6 discusses the rural land institution in China. The chapter starts with current theoretical debates on the land tenure issue in rural China, and then explores the empirical results of the latest round of farmland registration work in the country. It ends with an analysis of the possibility of applying two different land institutions in China.

Chapter 7 summarizes the research findings, reflects on the methodology, and discusses the implications of the research for Chinese agricultural policymakers. Moreover, this chapter provides a systematic discussion on transitional rural China. It points out that key problems in the Chinese "three rural issues" have changed, and that new challenges have emerged. 


\title{
2. Getting the Data Right: Main Trends in China's Agriculture and Food Sector
}

\begin{abstract}
This chapter has three parts. The first part discusses the multiple agricultural production modalities that currently can be observed in China. By analysing the complexity of the existing modalities, it will be shown that agricultural production in China still relies strongly on peasant farming. The second part explains that China's relation with the global food market is influenced by the domestic agrarian change. This implies that China's overseas agricultural investment and the domestic agrarian situation should be studied together instead of being separated from each other. The third part focuses on the internal changes of the agricultural production in China. Based on the thesis of 'hidden agricultural revolution' as elaborated by Philip Huang, it is argued that dietary transition indeed plays a critical role in the restructuring of the agricultural production in China. But this is only an exogeneous driving force. The endogenous drivers of structural change in agricultural production is the rapid increase in land rent and labour costs in China. Agricultural structural change is a process of mutual interaction between the exogenous conditions and the endogenous conditions.
\end{abstract}

Key words: agriculture, food, China, agrarian transition, land, labour 


\subsection{Introduction: getting the data right}

In current literature on China's agriculture and food sector one can distinguish three main foci. The first focus highlights the oversea impacts. Since the global food price spike in 2007/08, much literature on a global land rush and on agricultural investments has been published. Herein China attracted much attention due to its large consumer population, evolving dietary structure and rapid industrialization. This literature refers to the double role of China in the global booms. The first role includes acting as a large buyer. China is the largest soy import country due to the traditional Chinese diet custom and the recently increased demand for meat. Today more than 80 percent of the nation's soy consumption is imported, and this occupies around 60 percent of the total global soy trade volume. The increasing demand for soya in China is the main driving force behind the widespread planting of soya in South America, where 'soy is the monoculture starlet of the agro-export model' (Oliveira and Schneider 2016). This is also the case with oil palm. According to the statistics, China is the single largest global buyer of palm oil. The import quantity of palm oil increased fivefold from 1996 to 2007, and this stimulated the expansion of monocrop production of oil palm in Indonesia and Malaysia (Borras et al. 2012). In addition, the sugarcane boom in Thailand, Cambodia, and Myanmar in recent years has close relations with the increasing demand for sugar in China, the tremendous sugarcane crushing capacity of sugar mills located along the southwest border of China as well as with the political economic changes of sugarcane production inside China (McKay et al. 2016). The same goes for the "sustainable reforestation" across Southeast Asia: 'a vast 300,000 ha of land in Cambodia, which was allocated for eucalyptus plantation to produce pulp for export to China' (Borras and Franco 2011). Second, China is a direct investor in overseas agricultural production and land resource. It is reported that China's land investments in Africa, including private entities, were aimed to produce jatropha, sugar, and maize, most of which can be used for food, feed as well as biofuel (Bräutigam and Zhang 2013, Von Braun and Meinzen-Dick 2009, Hall 2011). Different from the understandings on China as a large buyer, some literature does not claim that China is currently food insecure. Instead, they argue that China's overseas land acquisitions could be related with the expected food or energy shortages in the future that could emerge as consequence of climate change or sudden shocks in the global economy (Von Braun 2008, Duggan and Naarajärvi 2015, Sun 2011). Without making a close examination of China's domestic agricultural production, the literature assumes that China has to supply its domestic demand with global resources currently or in the future. As a result, investment in foreign countries comes to the core as being of strategic importance (Cotula et al. 2009, Zoomers 2010).

Opposite to the first approach, the other two blocks of literature focus on the changes within China's domestic agricultural production. One block of literature is headed by Philip Huang, who argues that the agrarian change of the past thirty years in China is a 'hidden agricultural revolution' that has 'capitalization without proletarianization' as special characteristic. According to Huang. the Chinese 'hidden agricultural revolution' is different from the classical western concept of 'agricultural revolution', which is exemplified by the English agricultural 
revolution in the eighteenth century and the 'green revolution' in India and Latin America during the 1960's and 1970's. The Chinese agricultural revolution is, on the contrary, represented by the great increase in total agricultural output which is valued instead of the obvious rise of land productivity or labour productivity. The reason for this phenomenon is that Chinese peasants turned to produce more high-value agricultural products, like meat, poultry, fish, milk, eggs, vegetables and fruits (Huang 2010). Huang believes the change of the Chinese agricultural production structure is due to the fundamental restructuring of Chinese food consumption habits. This revolution is led by Chinese peasant farms that invest more capital and labour into farming, rather than by large capitalist farms. Chinese agricultural production thus grows as a consequence of capital and labour intensification by small family farms (Huang 2011). This process is of capitalization in the sense that the means of production on the Chinese peasant farms are capitalized and meanwhile the farms produce more agricultural commodities for the market. However, this process does not involve many hired agricultural workers, it is characterized as ‘capitalization without proletarianization' (Huang 2012).

The second block of domestic-focused literature is more influenced by the agrarian Marxist perspective. Herein, scholars argue that the capitalization in Chinese agricultural production implies capitalist relations and class differentiation. New institutions for capital accumulation as e.g. cooperatives, family farms and dragon-head enterprises, are emerging from above and below. It leads to a de-peasantization tendency (Yan and Chen 2015). In addition, peasant farming has changed into non-peasant forms of agricultural production even if a rural household is still the production unit. Zhang and Donaldson characterize this as 'from peasants to farmers'. The different types of peasants include commercial farmers, entrepreneurial farmers, contract farmers, semiproletarian farm workers with Chinese characteristics, semiproletarian farm workers and proletarian farm workers (Zhang and Donaldson 2010). As a result, the new agrarian class structure includes five social classes, that is, the capitalist employer class, the petty bourgeois class of commercial farmers, the dual-employment households, wage workers and subsistence peasants (Zhang 2015).

The two blocks of literature aim to explain the agrarian transition inside China by looking into capitalization and proletarianization of agricultural production. However, the former block focuses on the internal changes of peasant household farming. Capitalization was examined within peasant farms, and it means a process of more capitalized means of production but without capitalist relations. The latter block pays attention to the external changes of peasant farming, which means the new actors in agricultural production and the emerging capitalist relations between peasant farms and the new actors. However, neither of the two approaches notice or explain well the changing situation of agricultural production factors in themselves, namely, land, labour, and capital. Besides, responding to the oversea focus thesis, the latter two approaches hardly touch on the domestic agricultural production situation and its interaction with the global market, which can strongly influence the agricultural production structure and modalities inside China. 
In this chapter, I engage with the three foci on agrarian change in China and also the related food security issue ${ }^{14}$. Most importantly, I will try to answer several overarching questions. They are: What are the agricultural production modalities in China, and what can we see from the complexity of the diverse modalities? Is the gap between China's domestic production and its demand for food really so high that it can explain China's land and agriculture investments abroad? What is the relation between the structural change in agricultural production and the restructuring of consumption habits, or more precisely, is the former caused by the latter, as Huang argues?

\subsection{Agricultural production modalities and the agrarian transition in China}

According to Green Book of Rural Area 2014-2015 (农村绿皮书 2014-2015), until 2014, food production in China realized a successive increase during the previous eleven years. In 2014, the gross output of grain was more than 600 million tonnes and the rate of increase was $0.9 \%$ compared to 2013 . The meat production grew by $2.0 \%$ to 87 million tonnes of total output. Cash crops had shown great fluctuation due to domestic price policy adjustments (especially for cotton) and international trade (especially for sugar). In terms of employment, 2014 is the first year in which rural employment was below $50 \%$ of the total working population, but still as large as $49.1 \%$. The proportion of agricultural gross output value in the national economy kept shrinking in relative terms, but just as the Green Book clearly states, the new dynamics e.g. the national demand for agricultural products, the presence of new actors in agricultural production and the emergence of new forms of rural employment, confirm the pivotal position of agriculture for national development. ${ }^{15}$

The Green Book pointed out that new actors in agricultural production have been emerging in recent years. Land transfer is not limited to small-sacle peasant households, but is also open to specialized big households ${ }^{16}$, family farms, rural cooperatives, as well as urban industrial and commercial capital. In some typical land transfer regions, land tends to be concentrated by these new actors in agriculture. According to the Green Book, these new actors contribute to agricultural modernization. They fill the vacancies of farming caused by massive rural labour out-migration, and thus solve the problem of 'who will farm in China' to some extent. At the same time, it is mentioned that land enclosure by an alliance of local governments and industrial and commercial capital poses threats to stable food production and food security in the future.

In the Green Book three points are emphasized. First, food production keeps rising in China but the proportion of agricultural added value in Gross Domestic Product is small and keeps shrinking. Second, the rural population is still large, and agriculture plays an important role in

\footnotetext{
14 There are many definitions of food security by different official or research institutes. In this paper, the terms of "food security/insecurity" are used to refer to the food supply situation at the national level, which is related to the Chinese government's self-food sufficiency goal.

15 Chinese Academy of Social Sciences, 2015.Green Book of Rural Area 2014-2015. Beijing, Chinese Academy of Social Sciences.

16 'Specialized big households' refers to zhuanye dahu 专业大户 in Chinese. It is an old term referring the local big producers since 1980s.
} 
the employment of the national population. Third, new actors in agriculture emerged and gradually form a new structure of agricultural production. The three points raise the following questions: What are the agricultural production modalities in current China; what are the relations between them; and which is the main production modality in Chinese agricultural production?

A report published by Chongqing Survey Team of National Bureau of Statistics ${ }^{17}$ categorizes the current agricultural production actors in China into three types: 'household-led', 'cooperative-led' and 'corporate-led'. This classification is based on the production cost on labour, land, fertilizer, machinery, energy/fuel, and other input factors. However, the three terms are too broad and ambiguous to describe clearly the diversity of production modalities. In this chapter, I decompose the three categories and propose a set of theoretical concepts to build new constellations of the existing modalities in Chinese agricultural production today.

'Household-led' refers to the agricultural production type that is organized by individual households. Here the family is the unit of agricultural production and economic/livelihood calculation. In most cases, the production relies on family labour, but the family can also hire some seasonal or permanent labour. Thus, the 'household-led' type includes small-scale peasant farms and scaled-up family farms (also called specialized big households). The pervasive mode of small-scale peasant farms originated from the Household Responsibility System (HRS) during rural reform in 1980s. The scaled-up family farms have emerged with the land transfer among villagers since 1990s, but the amount of the scaled-up family farms increases fast recently with the government policy on promoting land transfer in rural areas (Chen 2013).

Conceptually, the 'cooperative-led' type still refers to rural cooperatives. However, this type is essentially different from the cooperatives in the 1950's or the People's Commune during 1960's and 1970's in China. The new rural cooperatives emerged especially after the passing of "Law of the People's Republic of China on Specialized Farmers Cooperatives" in 2006, although a certain number already existed before, mainly as pilots. According to the official document, Specialized farmer cooperatives are economic mutual-help organizations that peasants join voluntarily and are managed in a democratic manner by the producers/operators, or by the providers/users of agriculture-related services on production and operation. ${ }^{18}$

The 'corporate-led' type can be divided into two sub-categories. The first one is the 'agriculture industrialized dragon-head enterprises’ (农业产业龙头企业). Dragon-head enterprises have different linking forms with agricultural activities. The three most popular forms are 'company + households', 'company + production base + households' and 'company + cooperative + households'. The development of the vertical integration forms has been discussed by Yan and

\footnotetext{
17 National Bureau of Statistics of China, 2014. Research on the price relations of main agricultural products during production, distribution and consumption. Available from: http://www.stats.gov.cn/tjzs/tjsj/tjcb/dysj/201406/t20140612_567159.html [in Chinese] [accessed on $6^{\text {th }}$ Sept. 2016]

18 Ministry of Commerce, China., 2006. Law of the People's Republic of China on Specialized Farmers Cooperatives. Available from: http://www.fdi.gov.cn/1800000121_23_61763_0_7.html [in Chinese] [accessed on $9^{\text {th }}$ August 2016]
} 
Chen (2013). In the 'company + households' form, the company has the direct contract with scattered peasant households. With regard to the second and third forms, an intermediary agent exists between the company and peasant households. The difference between the two kinds of intermediary agents is that the production base is mostly a block of land that the company leases in to produce the agricultural products, while the cooperative is usually an independent agent owned by the village committee. ${ }^{19}$ The second sub-category is the specialized farming/breeding companies that emerged with the support from the state policy of 'industrial and commercial capital going into countryside', which was approved by the central government in 2013 in the 'No.1 Document'. Among these specialized farming/breeding companies, small or middle ones usually belong to private entrepreneurs while large farming companies are usually financed by large capital groups. However, all of them are directly engaged in agricultural production. The proponents of these agricultural enterprises argue that they bring high-technology and a substantial amount of capital into the countryside and they therefore can raise productivity and contribute to agricultural modernization (Li 2012). The opponents argue that industrial and commercial capital targets land investment rather than agricultural production, which acts as the Chinese form of "enclosure". It not only makes peasants lose land, but also results in a "non-food" phenomenon of rural land since the land investors expect to develop agricultural tourism and real estate in order to generate high profits (He 2014).

Figure 1. Schema of current agricultural production modalities and their interrelationships

19 Huanqiu Website, 2012. Organization modalities of agricultural industrialized operation. Available from: http://finance.huanqiu.com/mba/2012-08/3048672_3.html [in Chinese] [accessed on $9^{\text {th }}$ August 2016] 


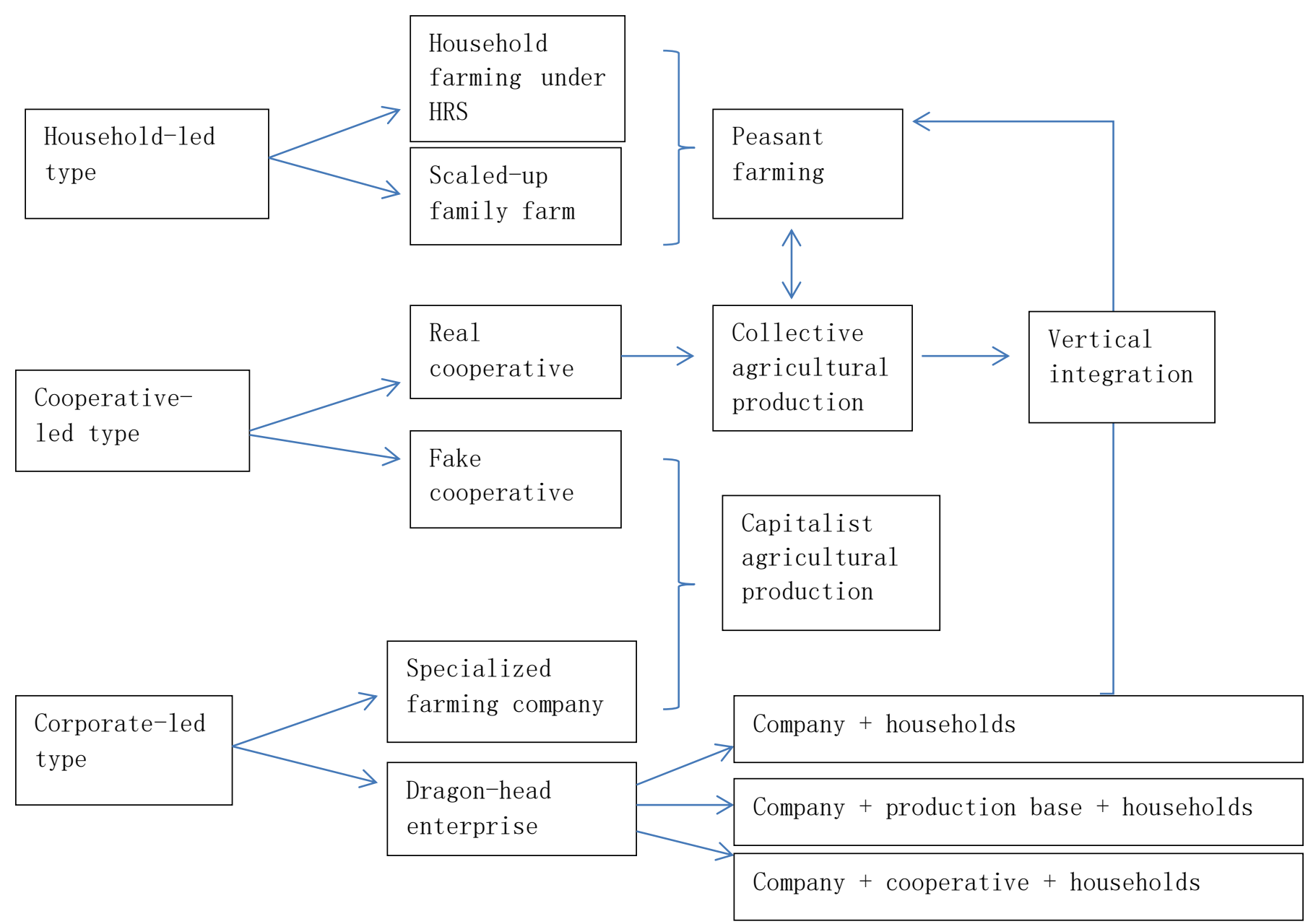

Note: The taxonomy is summarized by the author based on the author's empirical knowledge and theoretical analysis, as well as the relevant second-hand data from academic papers, media articles and governmental reports.

Fake cooperatives refer to the situations that some of the cooperatives are controlled by several rich households or external investors, whereas others are registered mainly to access to the government subsidies (Zhang 2014).

Although pieces of information on the agricultural production modalities can be found from journal articles, government reports or media news, this taxonomy provides a complete summary as well as an analytical tool for the modalities that can be currently observed in China's agricultural production. The evolvement of the agricultural production modalities in China has tight link with the governmental agricultural policies, which is also a critical issue to discuss. However, the limited scope of this chapter does not allow to expand on this topic.

The scheme shows two trends. One trend is the change within rural household farming, which I refer to as internal change. It concerns a scaled-up family farm which has different characteristics from the conventional household farm under the Household Responsibility System (HRS). According to the Ministry of Agriculture, up to 2013, China had around 267.5 million rural households while the number of family farms was 877000 (the data is excluding Tibet Province). This means that for every 1000 regular rural households there were 4.5 scaled- 
up family farms. ${ }^{20}$ The average scale of a family farm is about $200.2 \mathrm{mu}$, nearly 27 times that of the average scale of a regular rural household in China (Qiao 2013). Some scholars interpret the scaled-up family farm as entrepreneurial farming because they rent land, hire labour and produce for nonlocal markets (Huang 2010).

However, the scaled-up family farms are 'simply large peasant farms' according to Van der Ploeg, who considers them as peasant farms because of the following facts: First, most of these family farms are not built on financial capital (i.e. loans from banks), but on household savings. Second, their land is not originating from the free land market where land can be sold out and bought in with a market price. Instead, the land (use-right) owner can take it back. In fact, most family farms gain land through social networks inside their own communities and at a lower price compared to the price in the land transfer market. Third, even if they hire seasonal or permanent labour, the operation of family farms primarily relies on their own labour and techniques. Hired labour is to supplement a shortage of family labour rather than for creating surplus value. Fourth, the mechanism of farming is more based on peasant logic, meaning that they try to control the resource flow and avoid complete commodification in order to reduce their monetary costs. Income mainly derives from their own effort, including the work in the fields, techniques, and management. Fifth, the market is the outlet for their products, which is the characteristic that they share with small-scale peasant farming. Producing for the market doesn't change their way of farming and the market is not 'the ordering principle' for them. Finally, most family farms maintain a scale tailored to what the family can manage- instead of taking expansion as the final goal. In fact, once they expand beyond the scale they can manage, the family farm cannot function well (Van der Ploeg and Ye 2016). The covert change within peasant farming is related to their agricultural activities. Van der Ploeg and Ye point out the new strategies of intensification in small household farming, including labour investment in the resource base, intensifying cropping schemes, embedded specialization, space reorganization and on-farm processing (Van der Ploeg and Ye 2016: 66-79). According to Philip Huang, as Chinese peasants turned to produce high-value products under the 'hidden agricultural revolution', small family farms have become more intensive as far as the use of capital and labour are concerned.

The other trend is about the new actors and relations that are external to the peasant household and which I refer to as external relations. These agricultural actors are cooperatives, specialized farming companies and dragon-head enterprises. Each of them has a different relation with peasant households. While peasant households become members in real cooperatives and organize their production and marketing together, the fake cooperatives and specialized farming companies only need the land from peasant households. In a different way, dragon-head enterprises integrate peasant households into the food industry chain, but let them remain as producers. Clearly, these production modalities are not similar to peasant farming, and they differ from each other with regard to the system of agricultural production. Specialized farming companies and some fake cooperatives (in the sense that some capital owners concentrate land from villagers) organize agricultural production in a capitalist way, which means large-scale

${ }^{20}$ Since the statistical data of family farms does not cover Tibet province, for the percentage calculation the total rural household number should also exclude Tibet province as the corresponding denominator. 
farming, use of financial capital, high investments and new technologies (Van der Ploeg 2013). The real cooperatives are collective-orientated, which is the model of peasant economic organization and opposite to the capitalist organization of agricultural production, as argued by Chayanov (1986 [1925]). The most misinterpreted production modality is the one with collaboration between dragon-head enterprises and peasant households. Most scholars refer to this as capitalization. But here we should distinguish between capitalist production and capitalist penetration into agricultural production. There is a clear tendency of capitalist penetration into agricultural production through the commodification of seeds, fertilizer, pesticides, and standardization of farm products (Goodman and Wilkinson 1987, Sanderson 1986). This capitalist penetration into agricultural production can threaten the autonomy and sustainability of peasant household farming (Van der Ploeg 2012). However, the dragon-head enterprise modality is not a capitalist agricultural production modality since the basic production unit is the family household which is engaged in a peasant way of farming (see figure 1).

Although no statistical data exists on the contribution of capitalist agricultural production (specialized farming companies and fake cooperatives controlled by capital investors) to the national agricultural gross output, there are constantly reports on social media about the underperformance of the large-scale farms. A great number of them are reported to go bankrupt despite substantial government subsidies (He 2014). Meanwhile, it is reported that until 2014, more than 1.4 million rural cooperatives have been built and that the involved rural households are amounting to100 million ( $\mathrm{Li} 2014$ ). However, 80-95 percent of them are considered as 'fake cooperatives' (Liu 2010). The number of real cooperatives is thus very limited. Therefore, even if the agricultural production modalities and the actors of agricultural production in China are diversified, agricultural production still relies on household-led modalities wherein the dominant way of agricultural production is peasant farming. Nevertheless, Chinese agriculture production is very dynamic with regard to internal changes as well as external relations. While Philip Huang focuses on the internal changes of peasant farms and interprets it as 'capitalization without proletarianization' (Huang et al. 2012), Yan and others try to explain the 'capitalist new actors with de-peasantization tendency' by examining the external relations (Yan and Chen 2015).

This chapter argues that there are two concurrent trajectories of agrarian change in China. Firstly, Chinese peasant households are adjusting their farming strategies or changing the production modality (scaled-up and specialized) to accommodate the new markets and other socio-economic conditions. Secondly, whilst new production modalities and new ways of agricultural production are emerging, peasant households are building new relations with external economic organizations. However, to fully understand agrarian transition in China we should not only look into both internal changes and external relations, but also pay attention to the interaction between the two trajectories. The latter is more complicated and important to study. For instance, will peasant farms be able to coexist with capitalist farms in the long run by making use of their respective advantages, or will they compete with each other in the market until one way of farming will decline? How do peasant farms improve or, in what way are they challenged by cooperatives or Dragon-head enterprises? What will be the new relational 
dynamics between capitalist farms, cooperatives, and dragon-head enterprises? All these questions are essential for understanding the Chinese agrarian transition and the future of its agriculture and rural society.

\subsection{Changes in agricultural production factors and China's role in the global food market}

As mentioned in the introduction, research carried out by scholars abroad assumes that China's increasing demand for food-feed-energy is leading to its direct investment in land and agriculture abroad. The agrarian discussions held outside of China have focussed on China's impacts on resource acquirement, local agricultural production, and indigenous livelihoods abroad. But these research on China's overseas agricultural investment seldom looked into China's domestic agrarian transition. Yet, domestic agrarian change is tightly related to China's relation with the global food system. So how do we understand the agrarian transition inside China as well as its agricultural strategy abroad? Relating to this question, it is also important to figure out whether food insecurity is the reason for China's agro-food investments abroad and, whether these investments are directly on land and agricultural production, as both of these assumptions have been demonstrated as true in the land grabbing literature (Brautigam 2015).

According to the official statistical categories, the main agricultural products in China are grain, cotton, oil crops, sugar, wood, fruit, and vegetables. This chapter focuses on the farm products for food and feed, so cotton and wood are not included. The selected agricultural products can be divided into two groups: one group contains low-value agricultural products, including wheat, rice, corn, and soybeans; the other contains high-value products, like oil crops, pork, sugar, fruit, and vegetables. The line charts below show the trends of the annual outputs of these agricultural products since 1990 .

Figure 2. The annual outputs of low-value agricultural products since 1990 (unit: million tonnes). Data source: National Bureau of Statistics of China. 


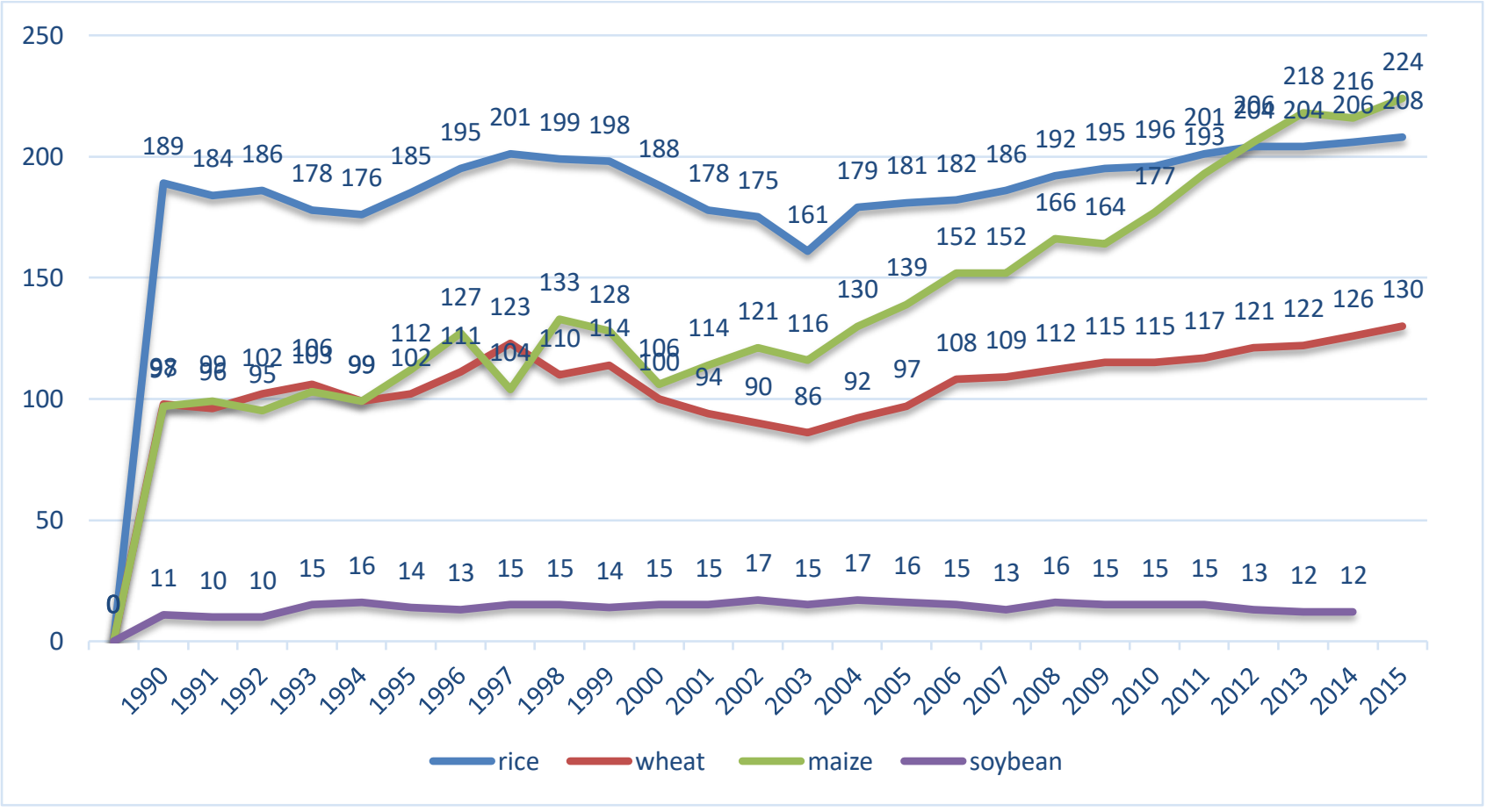

Table 1. The annual import-export volumes of low-value agricultural products in China since 1990 (unit: 10,000 tonnes). Data source: FAOSTAT

\begin{tabular}{|c|c|c|c|c|c|c|c|c|}
\hline & \multicolumn{2}{|c|}{$\begin{array}{l}\text { Rice } \\
\text { (milled equiv.) }\end{array}$} & \multicolumn{2}{|l|}{ Wheat } & \multicolumn{2}{|l|}{ Maize } & \multicolumn{2}{|l|}{ Soybean } \\
\hline & Import & Export & Import & Export & Import & Export & Import & Export \\
\hline 1990 & 5.89 & 32.60 & 1252.73 & 0.32 & 36.88 & 340.43 & 0.09 & 94.03 \\
\hline 1991 & 14.27 & 68.88 & 1236.77 & 0.17 & 0.05 & 778.19 & 0.08 & 110.90 \\
\hline 1992 & 10.36 & 95.28 & 1058.13 & 0.27 & 0.01 & 1034.02 & 12.07 & 65.82 \\
\hline 1993 & 9.62 & 142.04 & 642.39 & 8.69 & 0.03 & 1109.73 & 9.86 & 37.32 \\
\hline 1994 & 5.12 & 144.84 & 729.93 & 10.71 & 0.06 & 874.00 & 5.16 & 83.18 \\
\hline 1995 & 164.03 & 4.63 & 1159.00 & 1.62 & 518.10 & 11.25 & 29.39 & 37.51 \\
\hline 1996 & 76.04 & 25.44 & 824.60 & -- & 44.11 & 15.87 & 110.75 & 19.17 \\
\hline 1997 & 32.62 & 93.33 & 186.06 & 0.07 & 0.04 & 661.73 & 287.59 & 18.57 \\
\hline 1998 & 24.38 & 372.57 & 148.94 & 0.60 & 25.06 & 468.63 & 319.25 & 16.99 \\
\hline 1999 & 16.81 & 269.06 & 44.81 & 0.09 & 7.02 & 430.50 & 431.86 & 20.44 \\
\hline 2000 & 23.86 & 293.38 & 87.60 & 0.25 & 0.31 & 1046.56 & 1041.91 & 21.08 \\
\hline 2001 & 26.91 & 184.76 & 69.01 & 45.48 & 3.61 & 599.80 & 1392.95 & 24.84 \\
\hline 2002 & 23.56 & 196.39 & 60.46 & 68.76 & 0.63 & 1167.35 & 1131.44 & 27.59 \\
\hline 2003 & 25.69 & 258.50 & 42.42 & 223.75 & 0.12 & 1639.95 & 2074.10 & 26.75 \\
\hline 2004 & 75.64 & 88.10 & 723.29 & 78.39 & 0.24 & 231.82 & 2023.00 & 33.46 \\
\hline 2005 & 51.40 & 65.74 & 351.01 & 26.03 & 0.40 & 861.10 & 2659.00 & 39.65 \\
\hline 2006 & 71.82 & 121.84 & 58.41 & 111.41 & 6.52 & 307.05 & 2827.00 & 37.90 \\
\hline 2007 & 47.06 & 130.35 & 8.34 & 233.66 & 3.52 & 491.66 & 3081.72 & 45.65 \\
\hline 2008 & 29.33 & 94.68 & 3.19 & 12.59 & 4.91 & 25.25 & 3743.63 & 46.51 \\
\hline 2009 & 33.27 & 76.21 & 89.37 & 0.84 & 8.36 & 12.95 & 4255.17 & 34.66 \\
\hline
\end{tabular}




\begin{tabular}{lllllllll}
2010 & 36.32 & 59.89 & 121.87 & $<0.01$ & 157.24 & 12.76 & 5479.78 & 16.36 \\
2011 & 57.50 & 48.91 & 124.88 & 3.98 & 175.28 & 13.60 & 5245.29 & 20.83 \\
2012 & 233.44 & 26.66 & 368.86 & 0 & 520.71 & 25.73 & 5838.26 & 32.01 \\
2013 & 223.58 & 45.07 & 550.67 & 0.25 & 326.49 & 7.76 & 6337.78 & 20.90 \\
\hline
\end{tabular}

Figure 3. The annual outputs of high-value agricultural products since 1990 (unit: million tonnes). Data source: National Bureau of Statistics of China.

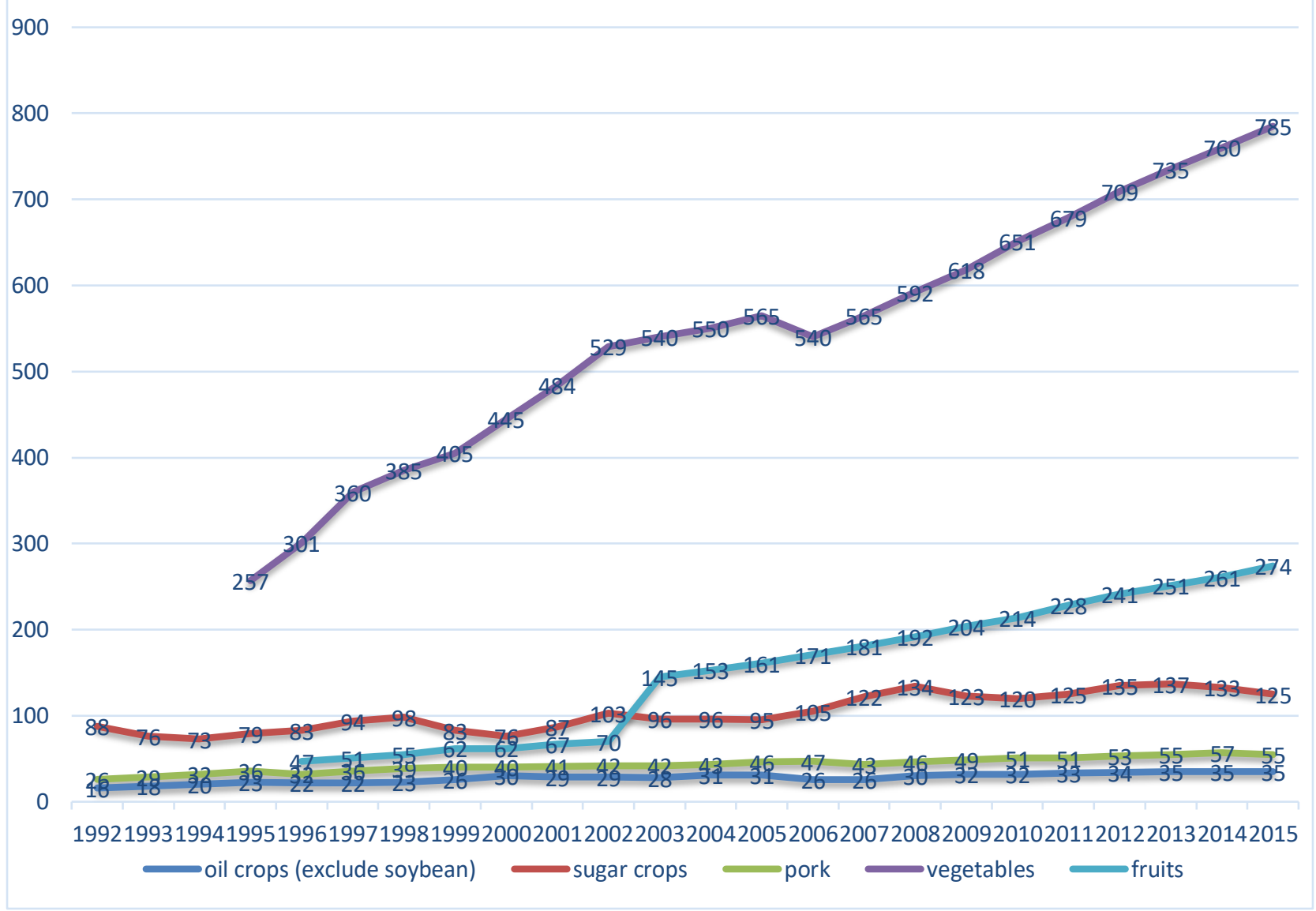

Table 2. The annual export-import volumes of high-value agricultural products since 1990 (unit: 10,000 tonnes). Data source: FAOSTAT, only the figures of edible oil are drawn from National Bureau of Statistics of China.

\begin{tabular}{|c|c|c|c|c|c|c|c|c|c|c|}
\hline \multicolumn{3}{|c|}{ Edible oil } & \multicolumn{2}{|c|}{$\begin{array}{l}\text { Sugar, Total } \\
\text { (Raw Equiv.) }\end{array}$} & \multicolumn{2}{|c|}{ Pork } & \multicolumn{2}{|c|}{$\begin{array}{l}\text { Vegetables } \\
\text { (fresh, nes) }\end{array}$} & \multicolumn{2}{|c|}{$\begin{array}{c}\text { Fruits } \\
\text { (fresh, nes) }\end{array}$} \\
\hline & Import & Export & Import & Export & Import & Fxns & Import & Export & Import & Export \\
\hline 1990 & -- & -- & 114.72 & 61.97 & -- & -- & 0.02 & 27.45 & 0.06 & 0.32 \\
\hline
\end{tabular}




\begin{tabular}{lllllllllll}
1991 & -- & -- & 101.77 & 37.27 & -- & - & 0.02 & 30.53 & 0.02 & 0.18 \\
1992 & -- & -- & 110.34 & 180.84 & -- & -- & 0.09 & 18.35 & 0.04 & 0.49 \\
1993 & -- & -- & 45.38 & 200.93 & 0.003 & 3.80 & 0.21 & 21.46 & 0.21 & 0.27 \\
1994 & 163.00 & 27.03 & 155.79 & 102.65 & 0.014 & 8.33 & 0.32 & 28.99 & 0.70 & 0.64 \\
1995 & 213.00 & 49.60 & 298.75 & 52.01 & 0.07 & 11.81 & 0.49 & 28.41 & 0.98 & 0.82 \\
1996 & 264.00 & 47.35 & 125.91 & 72.06 & 0.05 & 7.45 & 0.63 & 37.05 & 2.33 & 0.88 \\
1997 & 275.00 & 82.29 & 79.02 & 41.05 & 0.006 & 7.40 & 1.29 & 44.71 & 1.09 & 1.23 \\
1998 & 206.00 & 30.92 & 48.70 & 47.26 & 0.09 & 7.58 & 2.17 & 52.44 & 2.03 & 2.31 \\
1999 & 208.00 & 9.66 & 42.16 & 39.85 & 5.84 & 4.36 & 1.44 & 39.12 & 5.21 & 5.67 \\
2000 & 179.00 & 11.15 & 64.76 & 45.04 & 13.61 & 4.64 & 0.81 & 35.87 & 8.96 & 5.40 \\
2001 & 165.00 & 13.40 & 121.44 & 21.21 & 9.43 & 9.63 & 0.26 & 34.39 & 15.49 & 3.22 \\
2002 & 319.00 & 9.74 & 119.36 & 35.34 & 14.49 & 14.20 & 0.13 & 42.62 & 12.90 & 6.53 \\
2003 & 541.00 & 5.97 & 78.74 & 11.12 & 14.91 & 19.23 & 0.04 & 39.52 & 10.97 & 3.22 \\
2004 & 676.00 & 6.52 & 123.08 & 9.19 & 7.05 & 27.63 & 0.08 & 35.06 & 12.90 & 3.69 \\
2005 & 621.00 & 22.52 & 140.60 & 38.86 & 3.10 & 23.23 & 0.42 & 36.27 & 18.33 & 4.99 \\
2006 & 669.00 & 39.92 & 136.99 & 16.69 & 2.38 & 24.93 & 2.12 & 39.12 & 21.81 & 4.56 \\
2007 & 838.00 & 16.63 & 122.57 & 11.93 & 8.54 & 12.17 & 0.07 & 40.59 & 23.10 & 7.24 \\
2008 & 816.00 & 24.76 & 80.15 & 6.29 & 37.31 & 7.41 & 0.05 & 41.88 & 34.81 & 7.17 \\
2009 & 816.00 & 11.40 & 107.73 & 6.91 & 13.50 & 7.83 & 0.14 & 42.68 & 51.59 & 12.83 \\
2010 & 687.00 & 9.25 & 178.36 & 10.22 & 17.63 & 9.99 & 0.06 & 45.26 & 57.57 & 12.12 \\
2011 & 657.00 & 12.16 & 295.03 & 6.41 & 31.68 & 7.16 & 0.10 & 49.18 & 73.82 & 11.90 \\
2012 & 845.00 & 9.95 & 377.51 & 5.08 & 15.43 & 13.22 & 0.03 & 51.52 & 87.74 & 9.76 \\
2013 & 810.00 & 11.55 & 457.52 & 5.15 & 44.30 & 6.76 & 0.02 & 54.02 & 96.54 & 9.20 \\
\hline & & & & & & & & & & \\
\hline
\end{tabular}

From figure 2 and table 1, it can be derived that in the past twenty-two years the rice and wheat annual outputs show a similar trend: great achievements in the 1990's; and rising after a slight decline at the beginning of the 2000's. The trade data show that China has changed its role of rice exporter and wheat importer, and that both the rice export volume and the wheat import volume declined. This reflects the results of long-term government intervention policy that aims to equilibrate the balance of supply and demand of rice and wheat in the domestic market. Maize is probably the fastest growing low-value crop in China as its output has more than doubled during this short period. The trade data also reveal large maize exports in the past, but the export volume has continuously decreased. One reason is that the domestic maize price is protected by the Chinese government and is higher than the global market price. As a result, Chinese maize lost competitiveness in the global market (Chen 2016). Another reason is that the increased maize output can be largely consumed by the growing domestic demand for feed in livestock rearing and for raw material in energy, medicine, chemicals and bio industry i.e. intensive husbandry. ${ }^{21}$ Although there is a rising demand for soy as feed and raw material for industry, the soy production inside China witnessed a continuous decline whilst the soy import volume rose rapidly since 2000 (Yan et al. 2016). It implies that low-value crops that lack government-set prices are not the crop choices of Chinese peasants anymore. This situation also applies to oil crops and sugar, that turned from relatively high-value crops into low-value crops

\footnotetext{
${ }^{21}$ National Bureau of Statistics of China., 2016. Domestic food supply and the trend forecast of 'Thirteenth Five' Period. Available from: http://www.stats.gov.cn/tizs/tjsj/tjcb/dysj/201503/t20150313_693961.html [in Chinese] [accessed on $4^{\text {th }}$ Sept. 2016]
} 
due to the shrinking profit margin between the medium price in the market and the rising labour costs during production. Therefore, we can see in table 2 that the import volume of oil and sugar has kept growing year by year. Just as Huang argued, Chinese peasants turned to high-value agricultural products like meat, vegetables, fruits, etc. Figure 3 shows the dramatic boom of vegetables and fruits production in China, which has also resulted in the noticeable increase in the export of vegetables and fruits. Pork, the most consumed meat in China, also doubled in output in the past two decades, but the volume of imports still went up.

Looking at the domestic output, import and export data of the main agricultural products it becomes clear that China's agro-investments abroad are related to the structural change in domestic production, and not to food insecurity. The grain self-sufficiency rate is sufficiently high in China. The contradiction is between non-grain low-value crops (soy, oil crops, and sugar crops) and high-value products (meat, vegetables, and fruits). Chinese peasants have increased the production of food for both the domestic market and the global market. For the supply of soy, oil and sugar China has increasingly turned to the global market (see figure 4). Therefore, the argument that food insecurity is forcing China to invest in land and agricultural production abroad is questionable. Structural change in domestic agricultural production is the reason why China turned to an overseas agricultural investment. The structural imbalance of Chinese agricultural production therefor cannot be simply equated with food insecurity. Although China's import volume of soy, oil, sugar and other low-value crops is very large, the deficit in the balance of agricultural trade is not remarkable. This is mainly because China exports highvalue agricultural products to the global market. ${ }^{22}$

Figure 4. Depiction of domestic agricultural production trends and the relations between domestic agricultural production and the global food market in the past two decades (based on the figures and tables above).

${ }^{22}$ For instance, in 2014, China imported about 100 million tonnes of low-value crops and products (including grains, soy, vegetable-oil and sugar), with a total value of 59 billion USD. The export value of vegetables, fruits, aquaculture products, herbs, tea and tobacco were 44 billion USD. Data source: Guojia tongjiju. 


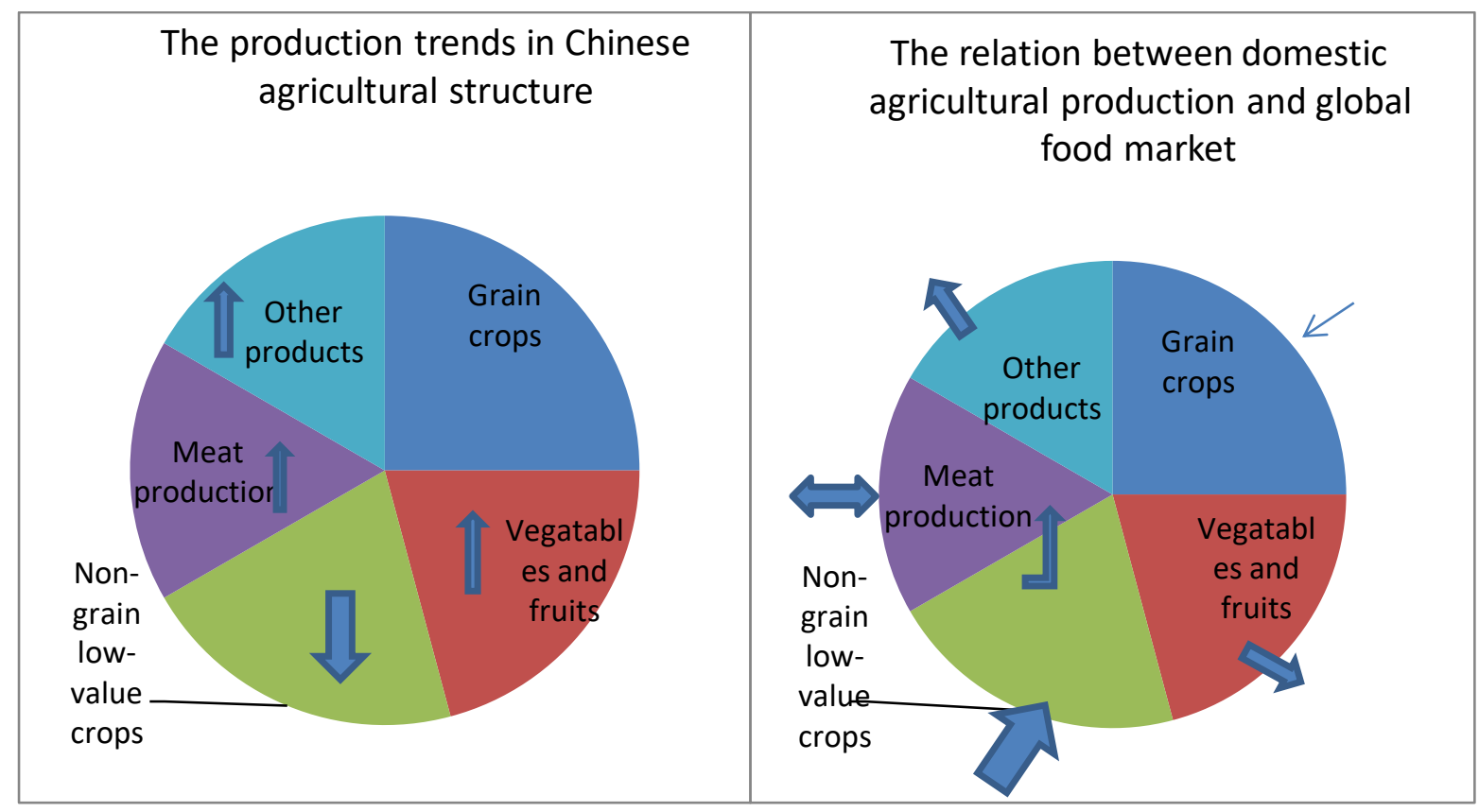

Note: "meat production" includes intensive husbandry and aquaculture; the double-direction arrow in the right pie chart reflects that China imports pork, beef, mutton, and poultry while almost equally exporting aquaculture products. "Other products" mainly refers to other high-value farm products that Chinese farmers produce, including herbs, tea, tobacco, nuts, silk, etc.

The domestic structural change in agriculture pushed China to seek for large amounts of lowvalue crops from abroad, which is the core of the Agricultural 'Go Out' (农业走出去) strategy. But the question is whether China's overseas agricultural investment critically depends on direct investment on land as the land grabbing literature argues. Cotula et al. (2009) explained, acquisition of foreign land for domestic food security is not part of China's mix of policies for national food security. In 2008 a draft policy document drawn up by China's Ministry of Agriculture did advocate the acquisition of foreign land for food security purposes, and the proposal was intensely debated; but finally, it was not adopted because of the perceived high political risks related to dependency on outsourced agricultural production for domestic food security. Hofman and Ho argued that not only the data quality and reliability about Chinese land grabs is problematic, but also China's overseas land-based investments should be understood as 'development outsourcing' - the contracting out of a business function to an external party due to comparative advantages in labour costs or economies of scales (Hofman and Ho 2012).

Although there is still a wide range and rich international debate on the objectives, mechanisms, scope and impact of overseas land-based agricultural investment, it might be argued that the goal of China's overseas agricultural investment is not direct land investment, but to get more secure channels of overseas food supplies and gain global power in the global agricultural commodity trade. Freeman and others pointed out that the Chinese government launched a series of measures to secure foreign supplies for its domestic food demand, among which resorting to the international market and state-supported agricultural project abroad are typical ways (Freeman 2008). On China's overseas state agribusiness, Xu and others argued that the 
China's state-owned enterprises (SOE) had turned into independent market players since the 1990s when the market-oriented reform started (Xu et al. 2014). Since the ABCD food companies $^{23}$ control about 90 percent of the grain trade in the world, and also have great power in the global sugar and oil market (Murphy and Clapp 2012). China is at a disadvantage in the global commodity value chain as a larger buyer. Therefore, China's overseas agricultural investment has been to compete with the global agribusinesses on purchase, processing, trade and transportation. For instance, to expand overseas China's sugar business 'COFCO' took over 'Australian Tully Sugar' and the 'Noble Agri Group' in 2011 and 2014 respectively (Ben 2011, Li 2013, Lin 2014). The sugar business covers a broad range of activities from sugarcane processing to transportation instead of land investment and sugarcane production.

To summarize, the agrarian discussion on China's overseas agricultural investment and its domestic agrarian change should be understood together. China is not a food insecure country currently. The recent increasing imports of agricultural products (mainly low-value products) is caused by domestic agricultural structural change. In addition, China exports high-value agricultural products, like vegetables, fruits, aquaculture products, herbs, tea, tobacco, nuts, etc. China is not a threatening land grabber either. Chinese agribusiness focuses more on food processing and trade rather than on direct investment in land and agricultural production. The controlling of the agricultural commodity chain and the value appropriation by giant global agribusiness in fact demonstrates the "food empire" framework argued by Van der Ploeg (2012), Chinese food companies are just the same as other global agribusinesses.

\subsection{Agricultural structural change in China}

The 'hidden agricultural revolution' mainly refers to the agricultural structural change within China. Its driving force is the transformation of the food demand rather than the factors internal to agriculture (such as seeds, fertilizer, new machinery, etc.). The Chinese diet structure of grains, meat-fish, and vegetables-fruits changed from the traditional 8:1:1 to 5:2:3 in the past thirty years (Huang et al. 2012). The rising demand for meat-fish, vegetables-fruits and their higher value-added properties attracted peasants to produce these products. Huang argues that the change in agricultural production resides in the output value instead of productivity. The output value of meat-fish and vegetables-fruits was about two thirds of the total agricultural output value in 2007 compared with only one sixth in 1978. Besides, these agricultural products boosted the whole output value of agriculture. In 2007, the total output value of agriculture was 5.1 times of that in 1980 (Huang 2012). Many studies reach the same conclusion, i.e. that Chinese dietary food demand has turned to less grain and more meat-fish-milk-vegetablesfruits. Although these studies are from different perspectives, including the rising consumption of meat and milk, nutrition transition, the impact of income on food demand and the tendency of eating outside the home, etc. (Delgado 2003, Du et al. 2002, Guo et al. 2000, Ma 2012). However, the question arises to what extent the product structural change in agricultural production is caused by the exogenous force of the diet structure transition?

\footnotetext{
${ }^{23} \mathrm{ABCD}$ food companies refers to the four giant transnational food companies; they are Archer Daniels Midland, Bunge, Cargill, and Louis Drefus. The four companies dominate the global trade of main agricultural products, like grain, soy, edible oil, sugar, etc.
} 
Table 3. The main food products consumed per capita in the diet structure of urban and rural residents in China since 1990 (unit: kg). Data source: National Bureau of Statistics of China.

\begin{tabular}{llllllllll}
\hline & & Grains & Vegetables & $\begin{array}{l}\text { Veg } \\
\text { oil }\end{array}$ & Pork & Eggs & Milk & $\begin{array}{l}\text { Aquatic } \\
\text { products }\end{array}$ & Fruits \\
\hline \multirow{4}{*}{ Urban } & 1990 & 130.72 & 138.70 & 6.40 & 18.46 & 7.25 & 4.63 & 7.69 & 41.11 \\
residents & 1995 & 97.00 & 116.47 & 7.11 & 17.24 & 9.74 & 4.62 & 9.20 & 44.96 \\
& 2000 & 82.31 & 114.74 & 8.16 & 16.73 & 11.21 & 9.94 & 11.74 & 57.48 \\
& 2010 & 76.98 & 118.58 & 9.25 & 20.15 & 10.40 & 17.92 & 12.55 & 56.69 \\
& 2015 & 101.6 & 104.40 & 10.70 & 20.70 & 10.50 & 17.10 & 14.70 & 56.05 \\
\hline & 1990 & 262.08 & 134.00 & 3.54 & 10.54 & 2.42 & 1.10 & 2.13 & 5.89 \\
Rural & 1995 & 256.07 & 104.62 & 4.25 & 10.58 & 3.22 & 0.60 & 3.36 & 13.01 \\
residents & 2000 & 250.23 & 106.74 & 5.45 & 13.28 & 4.77 & 1.06 & 3.92 & 18.31 \\
& 2010 & 208.85 & 102.28 & 4.90 & 15.62 & 4.71 & 2.86 & 4.94 & 17.18 \\
& 2015 & 150.44 & 93.28 & 5.52 & 14.40 & 5.12 & 3.55 & 5.15 & 19.64 \\
& 2010 & 90.30 & 9.20 & 19.50 & 8.30 & 6.30 & 7.20 & 29.70 \\
\hline
\end{tabular}

Note: This is an estimated table, since only the data of purchased food quantities per capita by the urban residents can be found before 2013. However, the data can still provide the clear trends on diet strucutral change in China.

Table 3 verifies that Chinese food demand has turned to less grain and more high-value added products such as meat, dairy products and fruits. However, the vegetable data seems to not match Huang's argument. The point about vegetables is that although the per capita consumption by both urban and rural residents declined, the fast urbanization and the increased population in China imply that total demand increased. ${ }^{24}$ Thus, the diet structure transition is one reason that drives Chinese peasants to produce more high-value products. However, from the trade data in the third section we have seen that China also exports large amounts of vegetables, fruits and aquaculture products. In addition, Chinese peasants also turned to produce more herbs, tea, tobacco, nuts, silk, etc., which are high-value crops, but have little relation to the dietary structural change in China. Therefore, it is indispensable to look also into the factors within agricultural production that possibly relate to agricultural structural change. In this chapter, I mainly examine the changes in market prices of farmland and rural labour.

In theory, if we want to examine the fluctuation of labour cost in agricultural production, the average wage for hired agricultural workers should be investigated. However, in the context of China agricultural production still mainly relies on family labour, which is non-marketized (see Huang et.al 2012). Besides, the very limited data on wage of hired agricultural labour in certain agricultural activities (for instance vegetables and fruits production) cannot represent the rural labour price in general. In many studies on agricultural productivity or profit efficiency, 'shadow prices' was use as the approach to compensate the implicit price information (Coelli

\footnotetext{
24 The urban population rate went up from $26.41 \%$ in 1990 to $52.57 \%$ in 2012 . In 1990 , the urban population counted 301.95 million people and the rural population 841.38 million. In 2012, the urban and rural population counted respectively 711.82 million and 642.22 million people.
} 
and Rao 2005: 147). Shadow prices refer the generalized profit function incorporates price distortions resulting from imperfect market conditions, and socio-political and institutional constraints (Wang et al. 1996). Thus, another indicator is adopted in this chapter to understand the change of labour cost in agricultural production. Figure 5 shows the average monthly wages of peasant workers between 1993 and 2015. ${ }^{25}$ The average monthly wage of peasant workers signifies the opportunity wage of rural labour in China. The annual data of the average monthly wage of peasant workers indicates that the actual value of rural labour in China is nearly eightfold of that in two decades earlier.

Figure 5. Average monthly wage of peasant workers annually since 1990s. Data source: 'The trends of wage change among Chinese migrant workers: 1979-2010' ${ }^{26}$; and National Bureau of Statistics of China.

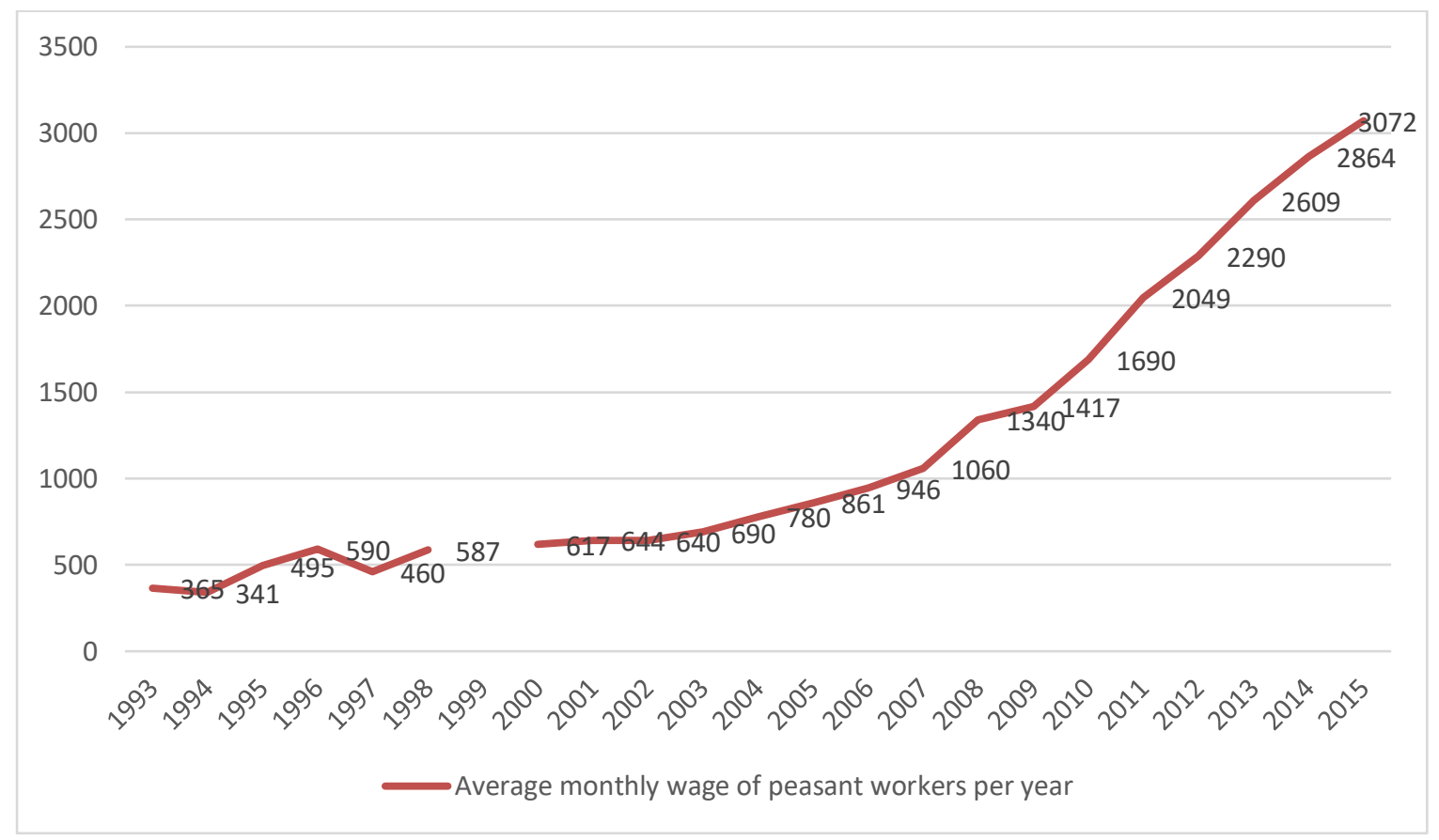

There are no nation-wide statistics on farmland price ${ }^{27}$ due to wide divergences in geographical location, land quality, economic influences and local government intervention. However, official reports and some regional studies have noticed the rapid rise of rental price in the farmland transfer market. As early as 2008 , a report by the Investigation Team of National Bureau of Statistics in Jilin province, already pointed out that the increasing land transfer price

25 The data of monthly wage here is not inflation adjusted. However, Zhang and Clovis argued in the paper titled as "China inflation dynamics: Persistence and policy regimes" that the persistence of the CPI inflation manifests a significant reduction around 1997; since the late 1990s China kept inflation low and stable. Zhang and Clovis, China inflation dynamics: Persistence and policy regimes. Journal of Policy Modeling 32(3), 2010: 373-388.

${ }^{26}$ Lu F., 2012. The trends of wage change of Chinese migrant workers: 1979-2010. Social Science in China, pp. 47-67.

27 There are different types of land in rural China, e. g. rural construction land, requisitioned land for urban uses. The prices for different types of land vary widely. This paper only focuses on the rental prices of the land used for farming. 
started to influence the production costs of crop planting, which became a restrictive condition to the production of low-value crops, like maize. ${ }^{28}$ In the following year, the Investigation Team of National Bureau of Statistics in Fujian province published a report on the situation of rural land transfer in Fujian. It showed that the land transfer price had doubled within a few years. ${ }^{29}$ One media report based on a survey on the land transfer price in Anhui province shows that the land transfer price increased five times between 2003 to 2013 (Zhang 2013). More discussions about increasing land price effects on agricultural production can be found in the media. Since growing grain crops became non-profitable due to high land costs, turning to planting high-value products and rural tourism became popular. 3031

Admittedly, many factors might impact upon the structural adjustment of China' agricultural production. But among theses the prices of the most relative factor (e. g. farmland and rural labour) are strategic, as convincingly argued by Hayami and Ruttan (1985). The increased shadow-prices of rural labour and farmland have driven the peasant households towards an ongoing intensification. They opted to plant the high-value crops, invested in new technologies, buildings and machinery. By doing so they responded on the one hand to the increased prices of land and labour and, on the other, provided the cities with their needed supply of more highvalue food.

Huang did not pay attention to the change of the most important factors inside Chinese agriculture production - the rising market price of land and labour. It is not logical that cropping structural change leads to a change in land and labour prices, but rather it is the opposite. Furthermore, Huang's analysis is limited to the production activities within rural households, which means that he left out the external relations of peasant farms i.e. with new agricultural production actors. With regard to the argument of 'emerging capitalist actors with depeasantization tendency', neither do Yan and Chen pay much attention to the changes of land and labour costs. It is critical to figure out how these new actors in agricultural production could develop with the increasing land rent and labour costs, and which production modality is able to succeed and that will last in the long run. As mentioned in the second section, although peasant household farming is still dominant in Chinese agricultural production, this modality is experiencing fundamental change inside and outside its production unit. The key to understanding current agrarian change in China is to examine the internal change of household farming, its external relations with new agricultural production actors and the interactions between the two trajectories.

\footnotetext{
${ }^{28}$ National Bureau of Statistics of China, 2016. Facilitate land transfer and promote working on 'three rural issues'. Available from: http://www.stats.gov.cn/ztjc/ztfx/dfxx/201012/t20101227 35288.html [in Chinese] [accessed on $18^{\text {th }}$ Sept. 2016]

${ }^{29}$ National Bureau of Statistics of China, 2009. Analysis on the situation of rural land transfer in Fujian Province. Available from: http://www.stats.gov.cn/ztjc/ztfx/dfxx/200907/t20090701_34848.html [in Chinese] [accessed on 18 Sept. 2016]

30 Sdnews, 2013. Scaled-up land turns to growing economic crops or tourism, the 'non-grain oriented risk' of land transfer. Available from: http://f.sdnews.com.cn/sdcj/201404/t20140423_1589738.htm [in Chinese] [accessed on $2^{\text {nd }}$ Oct. 2016]

${ }^{31}$ SJZnews, 2015. High land transfer cost challenges the grain farmers. Available from: http://www.sjzdaily.com.cn/finance/2015-04/09/content_2398451.htm [in Chinese] [accessed on $9^{\text {th }}$ Oct. 2016]
} 


\subsection{Conclusion}

This chapter presents a critical analysis of the current agrarian discussion on China. It tries to reinterpret the empirical data and reflect on the theoretical discussions.

This chapter categorized three general types of agricultural production in China - 'householdled', 'cooperative-led' and 'corporate-led' - and distinguished different production modalities in each type. Even though Chinese agriculture still relies on peasant farming, changes within peasant farming, new actors in agriculture production and emerging relations between peasant households and the new actors are shaping a different picture of agricultural and food production in China. Therefore, this chapter argues that it is necessary to look into both internal changes of peasant farms and their external relations with the new agricultural production actors, and to pay attention to the interactions between the two trajectories.

The data on China's domestic production and international trade show that the structural change of domestic agricultural production turned China into a large buyer of low-value agricultural products (like soy, vegetable-oil and sugar) from the global market. However, China cannot be simply labelled as food insecure country currently since it exports large amounts of high-value agricultural products instead (vegetables, fruits, aquaculture products, herbs, tea, tobacco, nuts, etc.). The possible effect of climate change or sudden economic shock on food security might be the concerns of China for its overseas agricultural investment, however, the Chinese overseas agricultural investment so far is not land-focused investment but more on gaining more secure channels of off-shore food supplies and market power on global food trade. Therefore, this chapter suggests that the focus of studies on China's agro-food activities abroad and the domestic agrarian debates can and should be taken together. Relating to the thesis of agricultural structural change in China, Huang only pointed at the exogenous cause - the restructuring of Chinese food consumption. As a complementary argument, this chapter points out the internal production factors of rising land rent and labour price are also important drivers of structural change in Chinese agricultural production.

For the policy makers in China, it can be challenging at this moment to make significant policy design on the agricultural and food sector. Since there are many contradictions emerging in the process, i.e. the contradiction between bring in new actors of agricultural production and ensuring rural livelihood, the contradiction between peasant farms growing high-value products and limiting grain importation, the contradiction between domestic food demand and profitable orientation of agricultural products export, the contradiction between opening to global food market and maintaining stability of domestic food supply, etc. However, the agrarian situation inside China and China's relation with global food market will continue changing, and simultaneously the debates will go on. 


\title{
3. Agrarian Change and the Pursuit of Self-supplied Food Security in
} China

\begin{abstract}
This chapter first unravels the new socio-economic challenges to China's self-supplied food security strategy. It then explores the interaction between agrarian change and the state intervention in agricultural production for achieving the political food strategy. This chapter argues: Firstly, the state focuses on food governance and the interests of large food companies, more than the small-scale peasants' needs for production and reproduction. Secondly, the new intervention project introduced capital intensive production modes, however which should be practically and theoretically distinguished from capitalist production. Thirdly, the centralized and top-down state intervention and capital investment in agriculture are squeezing the social-economic conditions of rural society as a whole instead of differentiating the peasantry. Nevertheless, the peasants involved in the intervention project did make different economic choices. These choices were based on their accessible resources to and the market situation of land, labour and other production factors.
\end{abstract}

Key words: food security, agrarian change, capitalization, peasant farming, class differentiation 


\subsection{Introduction}

In 2016, the Chinese central government introduced a document that outlines a nationwide adjustment of the crop planting structure, entitled 'National Planting Structural Adjustment Plan (2016-2020)'. This document states that the main problem in the current agriculture production has shifted from the insufficiency of total production to the production structural imbalance among crops. Thus, with the exception of wheat and rice, most crops are identified as unable to maintain a production-consumption balance. Maize, vegetables, fruits and tea have rapidly boomed in the past decade, while oil crops, sugar crops and cotton are shrinking in acreage - but with increasing imports from the global food market. To deal with this issue, the document aims to set specific production goals for different crops through regional allocation approach. The goals include but are not limited to the following: For grains, the total sowing acreage should be maintained at 1.65 billion mu, including 450 million mu for paddy, 330 million mu for wheat, 500 million mu for maize, 140 million mu for soy and 230 million mu for tuber crops. In the case of oil crops (excluding soy), sugar crops and cotton, the expected crops and related planting acreages are 100 million mu for rape, 70 million mu for peanut, 21 million mu for sugarcane, 3 million mu for beet and 50 million mu for cotton. Finally, the document also plans 320 million mu of land for vegetables and 60 million mu for forage crops (Ministry of Agriculture of China 2016). To achieve these goals - maintain, raise or reduce the planting acreage of each specific crop - regional allocation is considered. For instance, the central government has decided to resume soy production in the northeast provinces, protect cotton production in Xinjiang province and sugarcane cultivation in Guangxi and Yunnan provinces, reduce maize planting acreage in thirteen northern provinces, etc.

Although this document was issued in 2016, the relevant crop projects have been carried out for several years in practice. Provincial planting projects - with financial and institutional support from the central government - have been set up to achieve the allocated targets. As the new form of state intervention in food production, these projects generate new changes in the Chinese agricultural production and rural development. This chapter aims to explore the interaction between agrarian change and the state intervention in the agricultural production that aims to ensure national food security. The chapter is structured in three parts: First, it will explain the contradiction between new agricultural production trends and the self-supplied food security strategy. Second, it will review the policy transition of state interventions in agricultural production for the national food-security strategy since the 1980s. Third, it will focus on the implications of the recent crop planting projects, especially with regards to the social differentiation in rural China and peasants' economic choices.

This chapter takes the sugarcane project as a case study and uses both statistical data and fieldwork data in the analysis. Statistical data were mainly drawn from official databases, including the National Bureau of Statistics of China, FAOSTAT and other statistical publications. Fieldwork data were collected by the author during three periods of fieldwork in the Guangxi province during 2014 and 2016. In addition, other secondary data from reports, media, news and conference materials were consulted as supplementary information. 


\subsection{The new socio-economic challenges to China's food security strategy}

In the early years of China's accession to the WTO, the Chinese government and academia had divergent predictions about its impacts on the domestic agricultural production and rural livelihood. While many predictions tended to be negative, Jikun Huang and his research team argued the opposite: While imports of numerous land-intensive farm products may well increase, reduced protectionism may also boost output and exports of some labour-intensive farm products in which China still has a comparative advantage (Huang et al. 2007). Chinese farmers could be encouraged to adjust their cropping structure to increase the output and value, even if food prices fell. Therefore, the domestic agricultural production could moderately change under a trade liberalization environment, which mainly result from China's comparative advantages regarding the production of vegetables, fruits, aquaculture commodities and other high-value farm products (Anderson et al. 2004, Huang et al. 2003, Huang et al. 2007). More than a decade later, their prediction has been proven by the agricultural structural change in China.

There is another explanation for the structural change of China's agricultural production. Philip Huang called the recent agricultural structural change in China as the 'hidden agricultural revolution', which was caused by the restructuring of the Chinese food consumption. Put another way, the rising demand of Chinese consumers for high-value agricultural products like meat-poultry-fish-chicken-eggs and vegetable-fruits led to the increased output of these high-value products (Huang et al. 2012). However, Philip Huang over-emphasized the influence of food consumption on the agricultural structural transition, and paid little attention on the dynamics within agricultural activities. The two noticeable endogenous factors - which are also shaping the new trajectory of agricultural production in China - are land rent and labour price (Zhang 2016). This chapter tries to explain the challenges of China's agricultural production change to its self-supplied food security strategy. The price change of land and labour in the domestic market is taken as part of the cause.

The agricultural structural change in China can be observed from two angles: One is the change of land utilization among different crops, the other is the inner structural change of the total agricultural output value. Below I show the changed planting acreage of different agricultural crops since 1982 (Table 1) and the changed composition of the agricultural output value between 1995 and 2014 (Figures 1 and 2). The test years were selected as follows: First, because the Household Responsibility System was carried out nationwide since 1982. Second, because the output value of each specific agricultural crop was only recorded officially since 1995.

Table 1. The planting acreages of different agricultural product categories in 1982, 1992, 2002 and 2012 (unit: 1000 ha)

\begin{tabular}{|c|c|c|c|c|c|}
\hline $\begin{array}{l}\text { Product } \\
\text { categories }\end{array}$ & 1982 & 1992 & 2002 & 2012 & $\begin{array}{l}\text { Rate increase } \\
\text { in thirty years }\end{array}$ \\
\hline
\end{tabular}




\begin{tabular}{llllll}
\hline Grain crops & 113462.40 & 149007.10 & 154635.51 & 163415.67 & $44.0 \%$ \\
Beans (incl. soy) & $\begin{array}{l}8418.80 \\
\text { (soy only) }\end{array}$ & 8983.00 & 12543.10 & 9709.45 & $15.3 \%$ \\
Tuber crops & 9369.87 & 9056.50 & 9881.35 & 8885.89 & $-5.2 \%$ \\
$\begin{array}{l}\text { Oil crops (excl. } \\
\text { soy) }\end{array}$ & 9343.07 & 11489.40 & 14766.30 & 13929.79 & $49.1 \%$ \\
Sugar crops & 1115.60 & 1905.80 & 1871.50 & 2030.44 & $82.0 \%$ \\
Cotton & 5828.40 & 6835.00 & 4184.20 & 4688.13 & $-19.6 \%$ \\
& & & & & \\
Vegetables & 3887.47 & 7031.00 & 17352.93 & 20352.57 & $423.5 \%$ \\
$\begin{array}{l}\text { Fruits and } \\
\text { melons }\end{array}$ & 2434.67 & 6768.90 & 11452.75 & 14548.14 & $497.5 \%$ \\
Tea & 1096.93 & 1084.20 & 1134.24 & 2279.94 & $107.8 \%$ \\
Herbs & 95.47 & 254.00 & 963.91 & 1560.45 & $1534.5 \%$ \\
Forage crops & 1647.47 & 1786.80 & 3013.52 & 2060.81 & $25.1 \%$ \\
Aquaculture* & 3200.65 & 4476.18 & 6814.64 & 6854.40 & $114.2 \%$ \\
\hline
\end{tabular}

Data source: Except for aquaculture, all the figures are drawn from the National Bureau of Statistics of China. The figures on aquaculture are drawn from two data sources: The Thematic Database for Human-Earth System; and China Fishery Statistical Yearbook 1992, $2002,2012$.

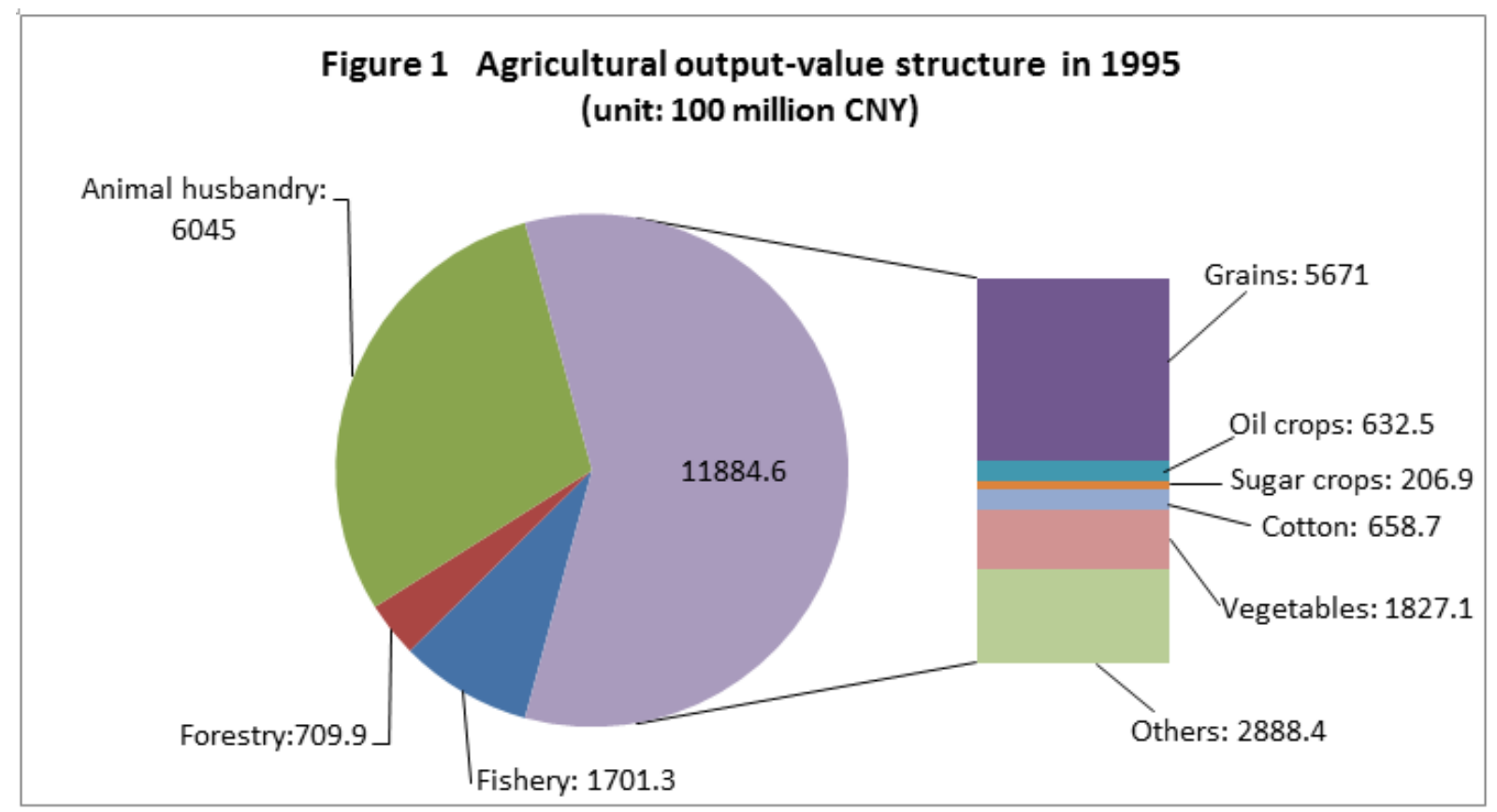

Note: The diagram is produced by the author based on two databases: one is the "Output Value and Income Database" provided by the Department of Crop Farming Administration, Ministry of Agriculture of China; the other is "China Statistical Yearbook 2015". 


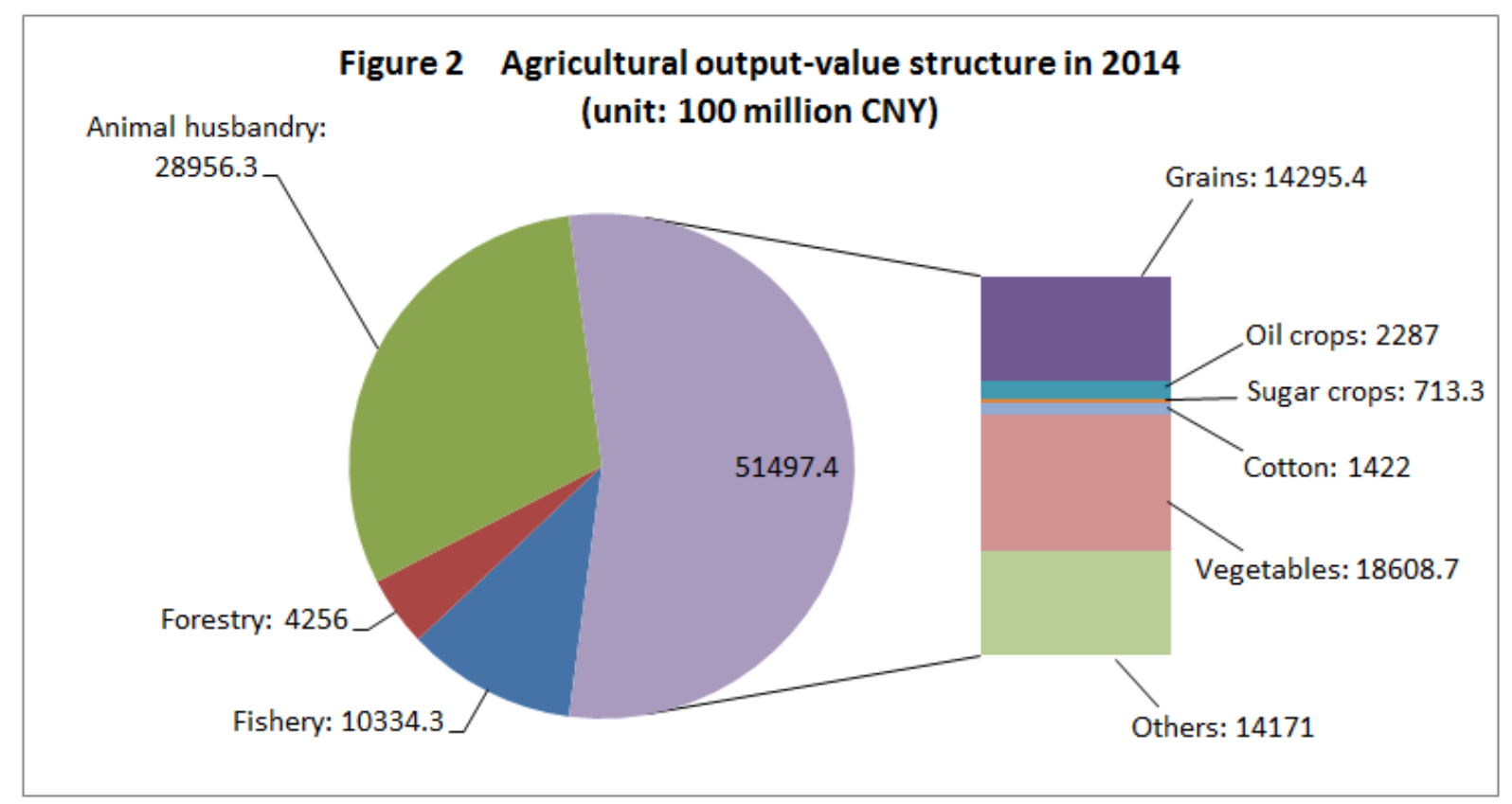

Note: This diagram is produced by the author based on two statistical publications: "China Agricultural Yearbook 2014" and "China Statistical Yearbook 2015".

Based on the data above, one can conclude that, while China's agriculture developed rapidly, its inner structure also changed dramatically. Among the four broad categories of agricultural activities, fishery and animal husbandry witness significant growth. Their output values are 3.8 times and 5.1 times higher than two decades ago, respectively. Within the farming sector, grain production had increased gradually, but its value contribution declined. Moreover, the land expansion for grain means less land being used for beans (especially soy), tuber crops and cotton. This phenomenon was induced by the central government's policy to protect the price of grains. Another remarkable transition is the boom of vegetables, fruits/melons and other high-value crops (like herbs and tea), in both sown area and output value.

Despite the remarkable achievements, there is a potential negative trend in the agricultural structural change: compared with the rising demand in the domestic market, the production of edible oil, sugar, cotton, soy and forage (for feed) has lagged behind. The downtrend in planting acreage of these crops has started in recent years. The most well-known case is soy, whose sown area shrank by 2.5 million ha since China entered the $\mathrm{WTO}^{32}$. In the case of oil crops, sugar crops and cotton, the downtrend has happened nationally but especially in the traditional production zones more recently. The national food security strategy ${ }^{33}$ met new

\footnotetext{
32 The data are drawn from the National Bureau of Statistics of China. http://www.stats.gov.cn/english/

33 The food security strategy is the Chinese central government's political framework on the domestic food production and supply, which consists of policies for maintaining food self-sufficiency in China. This strategy is very well explained by a media article, as follows: 'China's agricultural sector is supported by a number of policies that are collectively designed to achieve a food self-sufficiency objective. The objective stems from the Chinese Government's view that China's food security is best maintained by meeting its domestic food demand with domestically produced food and minimising its reliance on international markets' (The Poultry Site 2014).
} 
challenges regarding the self-sufficiency rates of edible oil, sugar and cotton. In addition, the gap between the declining domestic production of these crops and the fast-rising demand for their processed products keeps growing. This issue has aroused the government's attention, as the import volumes of these crop products increased quickly in the past decade. Figure 3 below shows the import volumes of soybean, edible oil, sugar and cotton since 2002.

Figure 3. Yearly import volumes of soybeans, edible oil, sugar and cotton since 2002

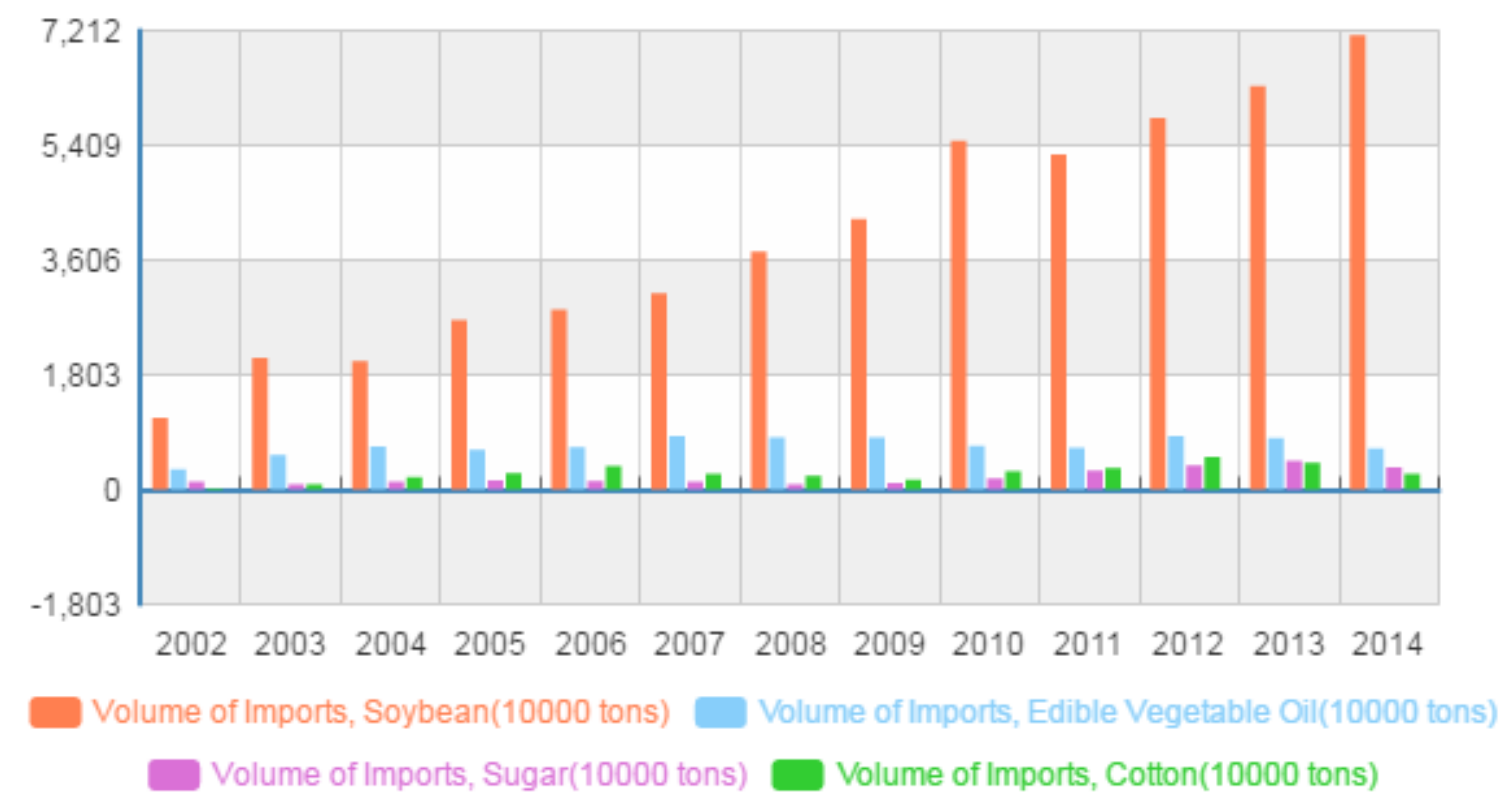

Data source: National Bureau of Statistics of China.

Edible oil, sugar and cotton are viewed by the Chinese government as strategic agricultural products, since their price fluctuation and market supply shortage can cause direct impacts on social stability. Similarly, soy has an importance role in the Chinese traditional diet and is also becoming the main crop for animal feed that indirectly supports the modern diet of the growing Chinese middle class - more meat, less grain (HH Hsu et al. 2001). The Chinese government would, therefore, not expect the supply of these crops to mainly depend on the external market, as that is economically and politically risky.

However, the micro-level farming activities challenge the macro-level national food security strategy due to two factors: The increasing land-labour costs, and the dominant peasant household production mode. Land rent has increased 2 - 5 times in different provinces of China within the past ten years, and labour price increased about tenfold in the past two decades (Zhang 2016). The high land and labour prices make the Chinese peasants reluctant to grow the land-and-labour intensive crops, like oil crops, sugar crops and cotton. This is especially so when considering these crops' moderate prices, which are expected to continue

However, the political framework of 'food security strategy' is not limited to food crops, but also includes the crops with high socio-economic influence such as cotton. 
decreasing because of opening to the global market. As Figure 2 shows, the high-value products - vegetables, aquatic products, or herbs - have been considerably produced.

In the state's view, the dominant production mode of peasant household farming has transformed from a cornerstone of the national self-supplied food security strategy to its barrier. In the 1980s, each peasant household prioritized grain production for their own subsistence and the national tax in kind. In certain regions where the natural conditions are suitable for oil crops, sugar crops or cotton, the government encouraged peasants to grow these crops and bartered for these products with grain. Through this family and state collaboration model, China has maintained its food self-sufficiency in the past thirty years. Since the new millennium, China abolished the agricultural tax and gradually opened its agriculture and food sector to the global market. While the tax abolition changed the previous peasant-state relation regarding the national food supply, the opening policy has put the Chinese peasants in the new situation of producing for the market. Far from being destroyed by the liberal policies, Chinese peasants have been very active in the market. They have adjusted their crop choices and farming plans according to the market prices of land, labour and crops, as proven by the emerged structural change of the agricultural production.

Therefore, opening the domestic food supply to the global market, the increasing domestic land-labour costs and the dominant production mode of peasant farms have driven the Chinese agriculture toward a trajectory of labour-capital intensification and high output-value oriented production. However, this transition of agricultural production mismatches with the political security of national food self-sufficiency, which is the strategy firmly stated by the Chinese central government. Thus, it should be understood that the contradiction between the agricultural production and the national food security goal in China is actually defined by political considerations and interventions instead of the changed socio-economic conditions.

\subsection{The historical transition of agriculture and food governance in China: The sugarcane case}

In the aforementioned context, a national planning on crop planting structural adjustment was proposed and then quickly carried out by the central government as the new intervention approach to ensure food self-sufficiency. As a result, a batch of crop planting projects were set up in different provinces. These projects aim to guarantee the production of the targeted crops in their traditional production zones through supporting large-scale mechanized plantations. The new food-security program deviates from the previous family-state collaboration model, and from the dominant peasant-household production mode. This chapter takes the sugar supply and sugarcane production as an example to look at the historical transition of agriculture and food governance in China.

Since the establishment of new China, a state-planned economic system was implemented. The sugar industry, as any other economic sector, was completely controlled by the state. All the sugar mills were state-owned, and sugarcane was supplied through production quota allocation system among collective production teams. At that time, feeding the stomach was 
the first goal of all farming activities. Sugar production was low, and sugar consumption was not common in Chinese people's daily diet (Si 2004). At this period, China's main food security issue was food shortage. The national-wide famine was due to the country's ideological antagonism with western countries and the broken relation with Russia during the 1950 s and 1960s. China's food trade relations with the external food market were not clear because of missing official data. Therefore, China was also left out from the geographical map and theoretical framework of the global food regime analysis (see Friedmann 1982, Friedmann and McMichael 1989).

It was not until the early 1980s - when the reform and opening-up policy were introduced and the Household Responsibility System (HRS) was set up - that the economic institution and started to change. However, the pattern of state-driving primitive accumulation did not change, in the sense that sugar mills were still state-owned. In this stage, sugar supply and sugarcane production were influenced by two intervention policies: "east sugar going west" and "grain-sugarcane barter". The "east sugar going west" policy was a regional development program, part of the central government's national development plan. Before the 1990s, Hainan, Guangdong and Fujian provinces were the main sugarcane production zone. Since the reform and opening-up, the southeast coastal area was designated as the special economic zone that would develop a labour-intensive manufacturing industry to attract foreign investment (Jiang 2008). The land in these provinces thus became scarce and expensive, and labour price became relatively higher than the inland area because of increasing job opportunities in factories. Since sugarcane is a land-and-labour intensive crop, the central government decided that the remote and poor southwest provinces like Guangxi and Yunnan should take over responsibility of domestic sugar supply. Thus, the sugar industry and sugarcane production transferred from the coastal region to the inland provinces where land and labour were cheaper.

The "grain-sugarcane barter" policy was then introduced as a complementary measure to motivate the peasants in the Guangxi and Yunnan provinces to grow sugarcane. Under HRS, land was distributed to individual households. Sugarcane production was no longer ensured through assigning production targets to the collective production teams. But individual households in the poor regions still gave the priority to growing grains, beans and tuber crops to maintain self-subsistence. It is reported that, the sugar supply could not meet the increasing demand in China in 1980s. Before 1988, the average yearly sugar consumption per capita was less than 3 kilos, and not everyone could access to sugar (Jiao 2012). To encourage peasants growing sugarcane, the state guaranteed that cane peasants would get an equivalent in grain. The basic idea of "grain-sugarcane barter" policy was to reward cane peasants with certain amounts of grain based on specific exchange rates which varied across provinces (State Council 1981). For instance, the Guangxi provincial government could get 400 kilos of grain from the central state when it produced one tonne of sugarcane (Jiao 2012). But those 400 kilos of grain were not fully distributed into the hands of the cane peasants, since the local governments extracted a certain portion for local grain reserves. In fact, Guangxi peasants could only receive a maximum of 110 kilos of grain when handing in one tonne of sugarcane (Guangxi government 1981). 
Nevertheless, the two intervention policies did guarantee the sugarcane supply and sugar production in China during the 1980s and early 1990s. There were two direct results: The first is the geographical relocation of sugarcane production inside the country - that is, the Guangxi and Yunnan provinces became the new sugarcane production zones. The second is that, while small-scale peasant household farming was admitted and respected by the state, the peasants themselves were economically squeezed by the state-led primitive accumulation.

There are a series of changes in the socio-economic environment since the 1990s, as the Chinese government took efforts to boost and liberalize the domestic economy. The first was to further show its belief and effort on foreign direct investment. The landmark event was Deputy Chairman Deng's inspection speech in south China, which showed the Chinese government's determination towards an opening reform and a market economy. The second step was the reform of the state-owned enterprise system, which opened some previous statecontrolled economic sectors to private/foreign capital (Lin et al. 1998). The third change was the fiscal and tax reform between the central and local governments. The basic idea of the financial reform is that the central government started to control the superior tax resources and at the meantime cut off the financial support for the local governments. It turned the local governments into 'local state corporatism', which refers to the strong incentives received by the local officials to pursue local economic development (Oi 1992). The three institutional changes transformed the pattern of capital accumulation in China. It is no longer the rigid state-driving primitive accumulation, squeezing peasants with direct administrative commands, but a market-based capital accumulation with government interventions.

Sugarcane, as was the case for other industry-related crops (cotton, oil crops and soy), experienced a boom period from the mid-1990s to the mid-2000s. Since the 1990s many stateowned sugar mills were acquired by foreign or domestic private capital (Luo 2009). For instance, the Thai MitrPhol Sugar Group, which is the largest sugar-and-bioenergy business company in Asia, merged five state-owned mills in the Guangxi province in 1993 and established the Nanning East Asia Sugar Company. This company gradually developed into the largest sugar company in China (see Baidu Baike ${ }^{34}$ and the Guangxi Nanning East Asia company website ${ }^{35}$ ). Later, the Yangpu Nanhua Sugar Company - owned by domestic private capital, and having developed the same way - became the second largest sugar related business company in the country. The public-to-private ownership transformation stimulated the Chinese sugar industry.

The other reason for the sugarcane boom is that the third regime of ensuring sugarcane production was set up during this phase. This was a market force and administrative regulation combined regime, which featured two policies - the "cane area regulation system" and the "cane pricing mechanism". The cane area regulation system was first designed to balance the competition and market share among the sugar companies. An equally important effect was that it was also a protectionist regulation for the local fiscal revenue. According to the official document, the sugarcane production zone in Guangxi was distributed to different

\footnotetext{
${ }^{34}$ Guangxi Nanning East Asia Sugar Group. Baidu Baike. Available at: http://baike.baidu.com/link?url=mBV2OXyBHSi5YcYF9naQKL1zWmsLyW2HM0myj2CVlHdzaZvrOrPkvUOy895JSegt_15eYbRTx7SiGU0EepG8a $\left[i n\right.$ Chinese] [accessed on the 26 ${ }^{\text {th }}$ July 2016]

${ }^{35}$ Guangxi Nanning East Asia Sugar company website: http://www.easugar.com/en/about_1.php [accessed on $26^{\text {th }}$ July 2016]
} 
sugar companies by demarcation (Guangxi Government 2002). In each area, the peasants are required to sell their cane to the assigned sugar company. Trans-area selling and purchasing are banned, except for some special agreements approved by the local government. The sugar companies deliver purchase vouchers to the peasants within its designated area as the agreement of trading between the two parties. The private selling of sugarcane without purchase vouchers to outside sugar companies is considered "illegal" 36 . Peasants who did so would be penalized by having their sugarcane impounded or receiving very few vouchers in the coming year. This system has a remarkable effect on the sugarcane expansion, since it provides the fixed channel of selling and purchasing sugarcane - the cane sown area in the Guangxi province soared from only 320, 000 hectares in 1990 to more than 1 million hectares in 2010, almost tripling in two decades ${ }^{37}$.

In terms of the cane pricing mechanism, every year Guangxi government sets a basic procurement price for sugarcane according to the sugar market situation, but the final sugarcane price is determined by the fluctuation of sugar price. For instance, in 2014/15, the basic procurement price of sugarcane was 400 yuan/tonne, which was linked with the sugar price of 5160 yuan/tonne ${ }^{38}$. But the actual purchasing price of sugarcane would increase by $6 \%$ of the increment of sugar price in the market. If we substitute $\mathrm{X}$ and $\mathrm{Y}$ for the actual cane price and the actual sugar price, then the relationship between the two prices would be $\mathrm{X}=$ $400+(\mathrm{Y}-5100) * 6 \%$. The price mechanism stabilizes the cane purchasing price each year, mitigating the peasants' worry about market risk. At the same time, it is the sugar companies that can generate large profits from eliminating price competition and maintaining stable resource supply. The price mechanism has effectively boosted the domestic sugarcane production and sugar industry. However, it also features significant inequality: First, the basic procurement price set by the government is low, approaching the production cost that increases year after year. Second, it is reported many sugar companies defaulted on the cane payments. $^{39}$

Since the mid-2000s, the rapid increase of domestic land rent cost and labour price again challenge the production of these land-labour intensive crops. In the sugarcane sector, the crisis started from 2012. Tables 2 shows the output value and production cost of sugarcane in China in the past six years. As it can be seen, the production cost of sugarcane increased by $30 \%$ between 2011 and 2014.

Table 2. Comparison of values and costs of sugarcane production in China in the last decade (unit: kilo per mu, or yuan per mu)

$\begin{array}{llllll}2009 & 2010 & 2011 & 2012 & 2013 & 2014\end{array}$

36 The discourse used by the local government and the sugar company when describing the situation.

37 The figures are obtained from the National Bureau of Statistics of the People's Republic of China: http://data.stats.gov.cn/easyquery.htm?cn=C01

38 Guangxi Price Bureau. Emergency notification on sugarcane purchasing price, issued in 2014/15. Available from: http://news.static.gsmn.cn/201412/03/106.000043.B7A2.html [In Chinese] [accessed on 27 $7^{\text {th }}$ July 2016]

39 People.cn. The Zuojiang sugar company's cane payment in arrear lawsuit ended. Available from: http://gx.people.com.cn/n2/2016/0801/c368791-28760165.html [in Chinese] [accessed on 28th July 2016] Yunnan sugar website. Guangxi cane peasants dun for default payments from the sugar company. Available from: http://www.ynsugar.com/Article/ZXZX/chanqu/201404/42459.html [in Chinese] [accessed on 28th July 2016] 


\begin{tabular}{|c|c|c|c|c|c|c|c|}
\hline \multicolumn{2}{|c|}{ Output } & 4738.99 & 4746.83 & 4710.21 & 5028.81 & 5177.72 & 4798.11 \\
\hline \multicolumn{2}{|c|}{ Output value } & 1517.44 & 2167.88 & 2327.06 & 2384.91 & 2294.58 & 1965.71 \\
\hline \multicolumn{2}{|c|}{ Total cost } & 1168.70 & 1382.01 & 1626.54 & 1978.96 & 2177.77 & 2115.76 \\
\hline \multirow{5}{*}{$\begin{array}{l}\text { Production } \\
\text { cost }\end{array}$} & Total & 1029.30 & 1221.09 & 1448.63 & 1786.52 & 1953.60 & 1881.39 \\
\hline & $\begin{array}{l}\text { Materials } \\
\text { and service } \\
\text { cost }\end{array}$ & 516.19 & 584.73 & 664.46 & 765.04 & 800.15 & 747.69 \\
\hline & Labour cost & 513.18 & 636.36 & 784.17 & 1021.48 & 1153.47 & 1133.70 \\
\hline & $\begin{array}{l}\text { Family } \\
\text { labour }\end{array}$ & 261.99 & 311.69 & 383.60 & 545.16 & 604.38 & 618.04 \\
\hline & Hired labour & 251.19 & 324.67 & 400.57 & 476.32 & 549.07 & 515.66 \\
\hline \multirow{3}{*}{ Land cost } & Total & 139.33 & 160.92 & 177.91 & 192.44 & 224.17 & 234.36 \\
\hline & Rented land & 6.28 & 7.70 & 8.35 & 11.37 & 16.17 & 19.03 \\
\hline & $\begin{array}{c}\text { Self-owned } \\
\text { land }\end{array}$ & 133.05 & 153.22 & 169.56 & 181.07 & 208.00 & 215.33 \\
\hline \multicolumn{2}{|c|}{ Cash cost } & 773.66 & 917.10 & 1037.38 & 1252.73 & 1365.39 & 1282.38 \\
\hline \multicolumn{2}{|c|}{ Labour income } & 743.78 & 1250.78 & 1253.68 & 1132.18 & 929.19 & 683.33 \\
\hline \multicolumn{2}{|c|}{ Net profit } & 348.74 & 785.87 & 700.52 & 405.95 & 116.81 & -150.04 \\
\hline
\end{tabular}

Data source: Compendium of source materials from the national survey of costs-incomes of agricultural products $(2014,2008)$

Given the falling profit from growing sugarcane and the land-labour price change, peasants try to find new strategies of balancing land-labour input and farming income to maintain their livelihood. According to the field observations, there are three main strategies they can make use of. One strategy is turning to high-value products, including watermelon, citrus fruits, sisal, tea, ginger, olive fruit and leaf mustard. These crops are labour-intensive, but their market prices are much higher than sugarcane. The second strategy is to return to traditional crops, like cassava, maize and beans. While growing high-value products involves with high risk due to market fluctuations, the traditional crops guarantee relatively stable income. More importantly, these traditional crops need relatively little labour. The third strategy is planting eucalyptus instead of growing farm crops. As eucalyptus hardly needs labour, peasants can convert their farm manpower into wage labour. This strategy changed the reality of increased labour price from an unfavourable condition for farming to an advantage for making a living. However, the dynamic relationship between eucalyptus and sugarcane is much more complex than only land and labour input (see Borras et al. 2018, Xu 2018).

The crop choice adjustment goes against the interests of domestic large sugar companies, as well as the state's strategy regarding sugar supply security. More specifically, according to the cane price mechanism, the purchasing price for cane is only linked with the sugar price in the market. Nevertheless, the business field of large sugar companies is quite broad. The products from sugarcane include sugar, pulp, electricity, bio-fertilizer, fodder, ethanol, monosodium glutamate, bio-chemicals, etc. Moreover, the large sugar companies also have their own businesses, such as logistics, labour service, agricultural machinery and food science research. Thus, the reduction of sugarcane production threatens the large sugar companies' entire 
business chain. For the state, it is an economic issue of protecting the domestic sugar industry from being destroyed by the global market. But, to a greater degree, it is also a political issue of ensuring the domestic sugar supply to maintain autonomy in international relations and domestic social stability. Therefore, crop choice is not simply a household-level economic issue that relates to peasant livelihood. It strongly impacts upon the accumulation process of agro-food capital and the political governance system of the state. In this sense, the large sugar companies and the Chinese government share the same goal - ensuring that enough land is cultivated with sugarcane.

From this idea, the "double-high" sugarcane project was launched. According to the yearly government documents, the overall project goal is to maintain the current sugarcane production acreage and lower sugarcane production costs. A main project task is to develop 5 million mu of modern sugarcane plantations in Guangxi. The actors to be subsidised by the project include: Sugar companies that possess large cane plantations, farming companies, sugarcane production cooperatives, and large households/scaled-up family farms (Guangxi Government 2013, 2014, 2015). Specifically, the eligibility for getting subsidies is above 200 mu of sugarcane land, which is nearly ten times as much as the average scale of peasant farms in the Guangxi province. Land transfer and concentration then became popular under the project. Another significant change is that the state-owned capital returned to the sugar industry after twenty years' withdrawal. The agribusiness accumulation and state food governance are completely integrated in this form.

This section has chronologically described four intervention regimes on domestic sugarcane production. The transition of intervention regimes is not only the result from policy adjustments, but also influenced by a series of changes in the market situation, the pattern of capital accumulation, the state's agricultural development philosophy and anticipation of peasant decision over time, the main implication of the 'food security'. Table 3 summarizes four periods of the agricultural and food production intervention and some directly related agrarian changes in China in the past half century based on the sugarcane case.

Table 3. The periodization of state intervention in agriculture and agrarian changes in China

\begin{tabular}{|c|c|c|c|c|}
\hline & $\begin{array}{c}\text { People's commune } \\
\text { period }\end{array}$ & Post-rural reform & $\begin{array}{c}\text { Fiscal reform and } \\
\text { foreign capital } \\
\text { "bring-in" policy }\end{array}$ & Post-WTO \\
\hline Period & $\begin{array}{c}\text { Before the early } \\
1980 \mathrm{~s}\end{array}$ & $\begin{array}{c}\text { early 1980s to early } \\
1990 \mathrm{~s}\end{array}$ & $\begin{array}{c}\text { early 1990s to mid- } \\
2000 \mathrm{~s}\end{array}$ & since the mid-2000s \\
\hline $\begin{array}{c}\text { General market } \\
\text { situation }\end{array}$ & $\begin{array}{c}\text { Planned economy; } \\
\text { no formalized } \\
\text { domestic food } \\
\text { market and trade }\end{array}$ & $\begin{array}{c}\text { Controlled domestic } \\
\text { food market and } \\
\text { trade }\end{array}$ & $\begin{array}{c}\text { Administratively } \\
\text { intervened domestic } \\
\text { food market and } \\
\text { trade }\end{array}$ & $\begin{array}{c}\text { Capital-force } \\
\text { intervened domestic } \\
\text { food market and } \\
\text { trade; }\end{array}$ \\
\hline Capital property & State-owned capital & State-owned capital & $\begin{array}{c}\text { Dominated by } \\
\text { foreign capital and } \\
\text { domestic private } \\
\text { capital; }\end{array}$ & $\begin{array}{c}\text { Foreign capital } \\
\text { remains; } \\
\text { domestic private } \\
\text { capital shrinks; }\end{array}$ \\
\hline
\end{tabular}




\begin{tabular}{|c|c|c|c|c|}
\hline & & & $\begin{array}{c}\text { State-owned capital } \\
\text { declined }\end{array}$ & $\begin{array}{l}\text { revival of state- } \\
\text { owned capital }\end{array}$ \\
\hline Intervention regime & $\begin{array}{c}\text { Assigning } \\
\text { production targets to } \\
\text { collective production } \\
\text { teams }\end{array}$ & $\begin{array}{l}\text { "East sugar going } \\
\text { west"; } \\
\text { "grain-sugarcane } \\
\text { barter" policy }\end{array}$ & $\begin{array}{c}\text { Cane area system; } \\
\text { cane price } \\
\text { mechanism }\end{array}$ & $\begin{array}{l}\text { "double high" } \\
\text { sugarcane base } \\
\text { project }\end{array}$ \\
\hline $\begin{array}{l}\text { Government } \\
\text { perception on } \\
\text { agriculture and } \\
\text { peasants }\end{array}$ & $\begin{array}{l}\text { Collective } \\
\text { agricultural } \\
\text { production }\end{array}$ & $\begin{array}{l}\text { Recognized the } \\
\text { function of } \\
\text { individual, small } \\
\text { household farming }\end{array}$ & $\begin{array}{c}\text { Relied on small } \\
\text { household farming }\end{array}$ & $\begin{array}{l}\text { Turning to large- } \\
\text { scale, mechanized } \\
\text { agriculture production }\end{array}$ \\
\hline $\begin{array}{l}\text { The main } \\
\text { implications of "food } \\
\text { security" }\end{array}$ & $\begin{array}{c}\text { The problem of low } \\
\text { agricultural } \\
\text { productivity and } \\
\text { output }\end{array}$ & Food self-sufficiency & $\begin{array}{l}\text { Food self-sufficiency } \\
\text { and rural income }\end{array}$ & $\begin{array}{l}\text { The contradiction } \\
\text { between peasant } \\
\text { livelihood, state food } \\
\text { governance and } \\
\text { agribusiness } \\
\text { accumulation }\end{array}$ \\
\hline
\end{tabular}

In a historical retrospective of the agro-food intervention regimes in China, one cannot avoid referring to Bruno Benvenuti's analytical framework - the 'Technological-Administrative Task Environment' (TATE). TATE is composed by the many institutions surrounding the agricultural sector (banks, agribusinesses, providers of services, extension agencies, state agencies, farmers' unions, etc.). These institutions increasingly prescribe and control the professional role of agricultural producers. It is indeed an 'environment' that specifies what is to be done, how it is to be done, at what time, in which sequence, for what kind of reasons, how it is to be monitored and evaluated, etc. Such a prescription mostly (or even completely) occurs through technical and administrative specifications. These are seemingly neutral Benvenuti argued, in this respect, that 'technology operates here as language', telling farmers what to do. Evidently, TATE is not a static phenomenon, but constantly changing (Benveuti 1975). In this respect Frouws argued that "change in the economic organization of agriculture implies changing roles for the economic actors involved, and also entails change in the meaning and sense of farm labour, 'produced' through the interlocking strategies and intentionalities of these actors (food manufacturers, input suppliers, farmers, retail corporations, finance and assurance companies) and the administrative rules that define the modalities of 'responsible', 'good', 'valuable', 'sustainable' agricultural practice” (Frouws 1997: 86). TATE offers a useful perspective to understand how external socio-economic structures influence the agricultural development path and farm practices. At the same time, Benvenuti also emphasized the agency of the peasantry. This can involve radical rural resistance, but more commonly manifests as peasant households adjusting their livelihood strategies through resource reorganization.

In the next section, I will discuss the influence of the most recent intervention regime on current agricultural production and the economic choices peasants made under this context, which also leads to a reflection on rural class dynamics.

\subsection{A reflection on the agricultural production path and agrarian class dynamics}


The post-WTO agricultural intervention regime has a kaleidoscope effect, the impacts being multi-dimensional - economy, society, governance, rural politics, rural culture, livelihood, etc. Moreover, the results are heterogeneous. Therefore, it is far beyond the scope of this chapter to explain them all. Instead, this chapter focuses on the project implication on the agricultural production path and agrarian class dynamics in rural China.

The "double-high" project attracted various types of capital, in two different ways. First, the project work is capital intensive. It involves building large farms and field roads, introducing improved cane varieties and large machinery, and constructing modernized irrigation system. Second, the ample governmental subsidies for the project is another attraction to capital holders. The subsidies include 1300-1500 yuan/mu for land consolidation, 300 yuan/mu for cultivating an improved sugarcane variety, $1540 \mathrm{yuan} / \mathrm{mu}$ for irrigation development, etc. As a result, the dominant pattern of peasant household farming in cane production was disrupted, and new modes of capital-intensive cane production emerged.

Capitalist plantation is only one of the capital-intensive production modes. Since 2013, the Kaili farming company successively developed eight large sugarcane plantations in the sugarcane production zone of the Guangxi province under the "double-high" project. Among the eight, two cane plantations are in the Fusui County - the largest cane producing county in China. One plantation is $6800 \mathrm{mu}$ in the Dubang hamlet ${ }^{40}$ and the other one is $6300 \mathrm{mu}$ across the Pabai and Palou hamlets. The plantations have realized sugarcane monocropping, planting mechanization, drip irrigation with integral control of water and fertilizer, and pesticide spraying by $\mathrm{UAV}^{41}$. Currently, the company is pursuing harvest mechanization, which is still in test because of the unfavourable natural conditions. Most of the cultivated land in the two hamlets were transferred to the company. Only the hilly or low-lying land, was left to the peasants themselves. The company hires villagers for the daily plantation work, but the labour demand is very limited outside the crushing season.

Different from the company mode, cane production cooperatives were also set up in some villages with the administrative instruction and financial support of the local government. The cooperatives in the Qulu and Gengfeng hamlets are two typical cases. The sugarcane production is as similarly mechanized and modernized as the company plantations. But there are several differences between the two modes: First, peasants exchange their land for the shareholdings of the cooperative economy, and their income is not offered as land rent but determined by the cooperatives' profit. Second, the cooperatives took over the members' land unconditionally, including the poor-quality land. Thus, the cooperatives try to make use of the unfavourable land by planting citrus trees on the hilly land and growing vegetables in the lowlying land. Third, the peasant income and the cooperative economy are bound up with each other. Thus, instead of sugarcane monocropping for labour cost reduction - as the company plantations did - the cooperatives need to diversify farming activities to generate more gross

\footnotetext{
40 In China, a village is a regional collection of several hamlets, which is administratively defined by the government. Due to the scattered residence of the Guangxi province, even a hamlet can cover broadly. 41 Unmanned aerial vehicle.
} 
value and working opportunities. Those activities include livestock breeding, forage processing, fruits and vegetables cultivation.

The third organizing mode is a quasi-cooperative one, which the peasants call as household joint farming. This mode is resulted directly from the land consolidation and re-allocation work that was carried out by the government to resolve the land fragmentation problem caused by the HRS. With the strong financial support of the "double-high" project, the local government implemented land levelling and re-allocation in many villages. As a result, in these villages, each household received a piece of non-scattered and relatively flat land which is equal to the sum of their previous, disconnected plots. The government therefore encouraged the community to mechanize the process of sugarcane planting and harvest together. Even so, a peasant household is still the independent farming unit and owns the autonomy to make farming plans. In this case, most households still intercrop sugarcane with watermelon and cassava to maximize earning from the land.

The fourth mode is the specialized, enlarged and entrepreneurial family farm. The officially defined family farms are above $200 \mathrm{mu}$ - the minimum requirement in the "double-high" project. Family farms are developed by individual households through a loan from the bank or the sugar company. They are also characterized by monocropping, mechanization and profit maximization. The difference between the entrepreneurial family farms and the company plantations is not only land scale, but also their relationship with the sugar company and the local villagers. As the company plantations control large resources (land and sugarcane), they have the economic power to negotiate with sugar companies for priority when receiving vouchers, transporting, asking for material support or cost compensation, etc. However, most entrepreneurial farms depend on the sugar company for either financial or social relation support. Regarding the relationship with the local villagers, the agricultural company has the social responsibility - pushed by the communities - to offer work opportunities to the local villagers first. This hiring relation has become the typical feature of the wage-labour based capitalist agricultural production mode. However, the entrepreneurial family farms have no such social pressure on labour employment. They choose cheaper workers, such as Vietnamese cane cutters, or sometimes their relatives or acquaintances who are not local residents. The hiring relation in the case of family farms is mostly seasonal and sometime kith-and-kin related. Thus, it has not completely developed into a capitalist hiring relation.

Therefore, the direct result of the "double-high" project is that it promoted capital intensive farming. Capital intensive farming should be distinguished from capitalist agricultural production. As Bernstein emphasized, the key to understand agrarian change is to 'investigate(s) the social relations and dynamics of the production and reproduction, property and power in agrarian formations...' (Bernstein 2010: 1). Since there is no capitalist hiring relation generated within the other capital-intensive farming modes - cooperative farming, peasant household joint farming, or entrepreneurial farms - it cannot be argued that Chinese agriculture is developing towards capitalist production. Yan and Chen have argued for the capitalist tendency of Chinese agricultural production from the capital accumulation perspective (Yan and Chen 2015). However, the penetration of capital control in agricultural production should be better understood as the process of commodification in agricultural 
production and the imbalanced power relation in market economy rather than agricultural capitalism, which implies a particular social relation in agricultural production. Van der Ploeg further pointed out that '[we cannot] view capitalism as the central nervous system of society as a whole, a view that implied that all activities (all production and all marketing) should be understood as capitalist' (Van der Ploeg 2016: 107). In fact, the cooperatives, peasant household joint farming and entrepreneur farms have production and social relations that are very different from the company plantations in terms of means of land concentration, labour regimes and mechanisms of wealth distribution. See table 4 below for an overview:

Table 4 Production and social relations of the capital-intensive production modes

\begin{tabular}{|c|c|c|c|c|}
\hline & $\begin{array}{l}\text { Company } \\
\text { plantation }\end{array}$ & $\begin{array}{c}\text { Peasant } \\
\text { cooperative }\end{array}$ & $\begin{array}{l}\text { Peasant household } \\
\text { joint farming }\end{array}$ & $\begin{array}{c}\text { Entrepreneurial } \\
\text { family farm }\end{array}$ \\
\hline Production unit & Company & Cooperative & Household & Household \\
\hline Production target & $\begin{array}{l}\text { Pure profit } \\
\text { maximization } \\
\text { maximition }\end{array}$ & $\begin{array}{l}\text { Gross income } \\
\text { maximization }\end{array}$ & $\begin{array}{l}\text { Gross income } \\
\text { maximization }\end{array}$ & $\begin{array}{c}\text { Pure profit } \\
\text { maximization }\end{array}$ \\
\hline $\begin{array}{l}\text { Means of land } \\
\text { concentration }\end{array}$ & Land transfer & $\begin{array}{c}\text { Land as } \\
\text { shareholding }\end{array}$ & Land re-allocation & Land transfer \\
\hline Labour regime & $\begin{array}{l}\text { Hired-labour } \\
\text { based }\end{array}$ & $\begin{array}{l}\text { Membership } \\
\text { labour based }\end{array}$ & $\begin{array}{c}\text { Family labour } \\
\text { based }\end{array}$ & $\begin{array}{l}\text { Seasonal hired } \\
\text { labour and kith- } \\
\text { and-kin labour } \\
\text { based }\end{array}$ \\
\hline $\begin{array}{c}\text { Mechanism of } \\
\text { wealth distribution } \\
\text { to peasants }\end{array}$ & Land rent & Profit sharing & Farming income & $\begin{array}{l}\text { Profit from } \\
\text { farming }\end{array}$ \\
\hline
\end{tabular}

As capital-intensive farming does not imply a full transition of social relations in agricultural production, then what is the essential change towards capital-intensive farming? Van der Ploeg has provided a perspective for analysing the material aspects of the production and distribution processes in the agro-food sector, which is interconnected with and complementary to the social relation analysis of producing and marketing agricultural products. He argued that the main questions that need to be asked are: 'What are the main resources? How are they developed? How are they converted into products? And how are these products channelled to consumers?' (Van der Ploeg and Ye 2016: 108). From the material conversion perspective, the farming activity under the "double-high" project is changing from a household self-provisioning, ecological capital based, and human-nature interactive process to a money capital intensive, financial debt (or governmental subsidies) dependent, natural resource controlling and speculating set of activities (Van der Ploeg and Ye 2016: 85-129).

One's understanding of the agricultural production path directly influences the analysis of class dynamics and politics in rural society. Agrarian Marxists see the agrarian change through a perspective that fits all new phenomena into the capitalist system. They argue that

\footnotetext{
42 In this chapter, I apply the terms used by Chayanov in his book of "The theory of peasant co-operatives". In the modern economics terms, 'pure profit' refers to marginal product value; 'gross income' refers to total product value.
} 
peasantry can be differentiated into capitalist farmers who reproduce themselves as capital, and medium/poor farmers that cannot reproduce themselves without selling their labour force (Lenin 1982, Bernstein 2010). Thus, the current agrarian change in China can be explained as a significant trend of class differentiation - capitalist employers, petty bourgeoisie/commercial farmers, dual-employment households, wage workers and subsistence peasants (Zhang and Donaldson 2010, Zhang 2015). Others point to the depeasantization tendency in the capitalization process of agricultural production (Yan and Chen 2015). Based on a different epistemology of China's agricultural production transition, this chapter holds a challenging opinion on the class differentiation analyses. In particular, it issues questions on two aspects: First, to what extent can the class differentiation that the Marxist scholars argued reflect the economic status and living level of peasant households? Second, to what extent may the class differentiation have link with the political appeals in rural society? The basic argument here is that, if the class differentiation cannot reflect the real economic status and the political choices of the peasantry, the defining of class groups is lack of validity. Thus, it is necessary to consider the peasant choices under the "double-high" project to fully understand the dynamics of rural economy and politics in China.

In the Palou hamlet, where a company plantation is located, most households own more land compared to other rural communities - above $50 \mathrm{mu}$. The families with fewer members and less economic pressure prefer to lease their land to the plantation because the considerable land rent can well support their daily living. In contrast, those families faced with more economic burdens (such as more children, children's education cost, marriage savings for sons, medical costs for elderly parents, etc.) are negative towards land transfers. They not only make the best use of their own land, but also tend to lease in land with low rent ${ }^{43}$ to gain more earning from farming. In the Shuangjun hamlet, whose community land is limited (with an average farmland per household of $5 \mathrm{mu}$ ), the villagers have engaged in non-farming work in cities or nearby towns since 1990s. Their land was levelled and concentrated under the "double-high" project and they run a joint farming mode to save labour from farming activities. In the Qurong hamlet, where the average land per household is moderate (the majority households own 10 to $30 \mathrm{mu}$ land), the village continues the tradition of reciprocal labour. Every year, eight to ten households organize a mutual-aid team during the crushing season to solve the labour demanding problem of the cane harvest. In this way, they gain income from their own labour. Moreover, due to the appropriate farm size, this hamlet experiences little out-migration. In contrast, the number of migrant families in the Palou and Shuangjun hamlets is remarkable. In the Qupo hamlet, a natural village close to the town centre, many households leased out land and opened family-run workshops (such as peanut oil extraction, noodle shop, etc.). Land income is the initial capital for their small business and most of them still rely on land rent to release cash flow pressure.

Based on these cases, some reflections can be drawn on the dynamics of rural society: First, the households that own more land comparing with their actual farming capacity choose to lease out land instead of accumulating land and capital to become "rural capitalist", which is

\footnotetext{
43 They pay low rent to get land because either the land is out of the flat and irrigated area, or the land lease agreement is arranged through a kith-and-kin relationship.
} 
due to less drudgery consideration but also highly contributed by the increasing land rent in China. Second, the households that have less land either seek for non-farming income or lease in land to expand and intensify farming activity. Between the two choices, demographic situation, technical skills and the tradition towards migration are the determinant factors. Third, In the sugarcane sector, seasonal labour is the main form of wage labour, permanent labour is rare. The hiring decision depends on the ratio of the number of working family labourers and the scale of cultivated land. Small farms without effective labour also need to hire labour. Thus, hiring labour cannot be simply taken as a criterion to distinguish class groups among the peasantry. Fourth, considering the HRS land institution in China, the peasants who stop farming are neither the poor proletariat nor the rural capitalist. They may act as local traders, shop owners or urban workers. But land value is still indispensable in supporting their livelihood. Fifth, the choices of leasing in/out land, hiring/selling labour, engaging in/abandoning farming are changing all the time among peasant households, according to the land rent, labour rent and food price on the market. A static classification of rural classes is unreliable. Moreover, the class groups argued by Zhang hardly reflect the peasant households' income level, but also are lack of relevance to an analysis of peasant resistance. This leads to the last reflection, namely that - although there are different economic interests and different livelihood strategies among peasant households in the "double-high" project - the fundamental economic and political appeal is the autonomy of land use rights ${ }^{44}$. By autonomy of land use right, this chapter refers the free choice of peasants, within legal boundary, on whether and when to lease out their land, what to grow on their farms. From the small land owners to the big land holders, Chinese farmers strive for land benefits based on the market situation, which can only be realized when peasants can decide what to do with land by themselves. The current main problem in rural China is less related to internal class conflicts and more related to the local villagers' efforts against external interventions.

In the case of rural China, the Household Responsibility System of the early 1980s distributed land to rural households in a relatively equal way ${ }^{45}$. Peasants make crop choices according to the (land-, labour-, product-) market situation. The crop planting programme is considered by the central government as the solution to the contradiction between the national food governance, agro-capital interests and the small-scale peasant household farming during the process of further liberalization of China's agricultural and food markets. However, the nature of these planting project plans is that the state and agro-food capital need land to prioritize the production of certain crops, which would, in turn, lead to cheap market prices. For this reason, the peasant household is not the ideal unit for agricultural production. Large investments on land concentration and machinery are the central task of these crop projects, and they are beyond the economic ability of individual peasant households. Instead of generating peasant differentiation, the project interrupted (to some extent) the expanded reproduction of the peasants who owned more land, since those peasants chose land rent and less drudgery. It also

\footnotetext{
44 In China, peasants only own land use right, the land ownership belongs to rural communities.

45 Unequal land possession currently exists in rural China, complicating causes and impacts. I will discuss the land issue in another chapter, but, for now, the majority of Chinese rural households possess a certain amount of land.
} 
had negative impacts on the relatively less landed households who wanted intensive farming by themselves because land rent cannot support their livelihood.

It is thus plausible to claim that the "double-high" project has resulted in neither income polarization nor class differentiation among the peasantry of the Guangxi province. Instead, it is a forceful top-down flow of governmental interventions and industrial-commercial capital into rural China. This flow is changing the current agricultural production paradigm and mode in China. Faced with top-down political and economic forces, even the cyclical demographic differentiation among the peasantry tends to be vague. In other words, the socio-economic space of the agrarian society in China is suppressed by the current consortium of administrative power and agro-capital. In this process, the cane peasants had diversified reactions - depending on their own resource situation (valid family labour, land scale, working skills, social relationships, etc.) - in order to achieve the optimal choices for their livelihoods. However, they all put land right autonomy as the bottom line for taking political actions. The agrarian Marxists' so-called differentiated class groups tend to ally with each other to fight for land benefits. The agrarian transition initiated from above turned land property and land right into the focus topic in rural society. Land issues have again become the core of agricultural production in China in this new historical phase. But the current agrarian change in China is a complex of on-going trends of agro-food governance, agricultural production paradigms, agricultural production modes, land property, labour regime and agro-capital accumulation in the changing food market situation.

\subsection{Conclusions and discussion}

This chapter first analysed the current challenges in domestic agricultural production to the national food security strategy in China. Using the sugarcane project as a case study, it documented the historical transition of China's intervention regimes in agricultural production for its food-security strategy. Finally, it reflected on the impacts of the current intervention project on agricultural production paths and rural society. While the accession to the WTO and the rising prices of land and labour in the domestic market have transformed the Chinese agricultural production into a 'capital-labour dual intensifying family farm(s)' based trajectory (Huang 2011), the state intervention of food security and the capital interest in agricultural and food industry are shaping a different production trajectory - in particular, large-scaled industrialized production for certain "needed" crops of cheap market prices. The post-WTO intervention regime is creating capital-intensive production modes with and without capitalist relations. Under the top-down agricultural project, peasants have different economic choices, which are based on their accessible resources and the concrete market situation of land, labour, food and other elements.

I argue that, with China's new agricultural production intervention policy, class differentiation among the peasantry is actually diluting, since the current agricultural program was not designed for individual peasant households. What should be clarified here is that no class differentiation among peasantry does not mean no class dynamics in rural society. For instance, the sugarcane project has shown that a new form of class contradiction between 
local peasants and intrusive agro-capital has emerged. In this sense, the autonomy of land use right has become the realistic basis of political process in rural China.

Finally, in terms of labour hiring in agricultural production, Zhang argues that family farming in China is undergoing a fundamental transformation because it 'is no less capitalistic than corporate farming organized by agribusiness using wage labour' (Zhang 2015: 362). This chapter holds a different understanding: hiring labour is not the defining attribute of capitalistic farming. Instead, the principles of distinction are whether the agricultural production activities rely on permanent employment relation, and whether the production process with hired labour is aimed at profit maximization or income maximization. In the sugarcane production case, large plantations and most peasant farms hire labour during harvest season and sometimes in the planting process. The peasant households hire labour due to a shortage of valid family labour and the lack of available advanced tools, which can be observed from the aging labour in rural society and the low level of mechanization in sugarcane production in China. For company plantations, the entire operation process is based on the employment relation to pursue profit maximization. In contrast, the peasant households still arrange farming activities according to the family's ecological and economic resources, and their goal is to maximize farming income. When it comes to the practical process, hiring labour is a way to compensate the shortage of family labour or expensive machines. As Wang argued in the Punjab state case, the 'consumptive utilisation of hired labour' by women and elderly people in farming activities to substitute their physical shortcomings is different from the 'productive utilisation of hired labour' in capitalist family farms for expanded reproduction (Wang 2009). Thus, labelling farming with hired labour as capitalistic farming might be simplistic. That being said, one must acknowledge that some expanded family farms are emerging that share many characteristics with corporate farming. This new agricultural production mode can be referred to as entrepreneurial farming, but the survivability of entrepreneurial farms needs further research and time to test. 


\title{
4. Three Strategies of Capital Accumulation in China's sugarcane sector: A Technological-Political-Financial Accumulation Synergy
}

\begin{abstract}
Capital accumulation in the agro-food sector displays new characteristics in modern society. By means of a case study of China's sugarcane sector, this chapter identifies three capital accumulation strategies that recently emerged. The first strategy is the redistribution of costs and benefits between farmers and companies through the introduction of new technologies which is known as agro-technification. The second strategy is termed food politicization and relates to the profound restructuring of both sugarcane production and the sugar market through massive state intervention. The third strategy is land swindle, namely the conversion of land from a means of production into an object of speculation. Following a discussion of the three strategies by drawing on developments in China's sugarcane sector, this chapter argues that these new capital accumulation activities will render national and transnational food systems more fragile and unsustainable. Moreover, it argues that classical agrarian analyses defining accumulation as a land-labour-capital triangular relation cannot explain the current capital accumulation in agro-food sector. Instead, a new triangular technologicalpolitical-financial synergy more aptly describes recent developments in the agro-food industry in general.
\end{abstract}

Key words: Capital accumulation, agricultural technology, food politics, land consolidation, China 


\subsection{Introduction}

\section{The general debate on capital accumulation in agrarian society}

Capital accumulation is currently a key driver of agrarian change across the world, as the result can be observed that agribusinesses have gained more power in every process of agricultural production and food supply. Although agrarian Marxists and pro-peasant intellectuals have different views on agricultural development, the fate of rural society, and the prediction of peasant differentiation, they all focus on capital accumulation in the agrofood sector. Classical Marxists tend to concentrate more on capital accumulation in the agricultural production sector. According to Marx, the first capitalists were landowners who expropriated land from peasants; primitive accumulation refers to the process of separating the producer from the means of production, thereby producing capital (Marx 2010 [1887]). Large farms (also referred to as "capital farms" or "merchant farms") could only be defined as truly capitalist in cases where farmers exploited wage labour to a greater extent and where the financial capital of the farm could accumulate ${ }^{46}$ (Marx 2010 [1887]). Lenin further developed the argument of capital accumulation in agricultural production and emphasized the potential crisis of peasant differentiation in rural society (Lenin 1982: 130). According to Lenin, the renting of land for commercial farming, the necessity of employing numerous farm labourers, and the generation of spare cash for farm improvements demonstrate capital accumulation by affluent peasants (Lenin 1982).

Kautsky, on the other hand systematically analysed the relations of capitalism and the peasantry in modern society, expanding the previous Marxist explanation of capital accumulation driven by agricultural production activities. He recognized the functionality of peasant farms in the capitalist economy; their "underconsumption" and "excessive labour" formed the basis of accumulation in capitalist agriculture and industry (Kautsky 1988 [1899]). On the one hand, peasant farms are "production sites" for labour that capitalist farms and industry require. Conversely, surplus value is extracted from peasants through technological packages, credits, contracts, as well as through the control of modern storage, transport and retail outlets by agro-industrial capital (Kautsky 1988 [1899]).

Kautsky's understanding of capital accumulation is not far removed from that of pro-peasant intellectuals (e.g. Chayanov and Shanin) who disapprove of the trend of capitalist class differentiation on peasant farms. He pointed out that capitalist profit extraction is made possible by upstream and downstream activities in the food supply chain, as well as by the credit system. Chayanov and his predecessors on the other hand did not explain capital accumulation to a great extent, but their work on peasant co-operatives show that the capitalist economy squeezes peasant farms through market specialization, machinery and science, processing, transporting, and retailing. In their view, a peasant cooperative is the best organizational system to compete with and to protect peasant farms from capitalist agriculture and industry (Chayanov 1991 [1927]).

\footnotetext{
46 According to Marx, other historical circumstances led to the rise of capitalist farmers in England. These circumstances include the progressive fall in the value of precious metals/money, the continuous rise in the price of all agricultural produce, and lowered wages. All these changes generated more profits for farm owners.
} 
Goodman et al. (1987) offered a systematic analysis of the industrial appropriation of rural production processes, exploring how industrial capital created accumulation sectors by restructuring the pre-industrial rural production process, including changes to agricultural equipment, processing, food manufacturing, and distribution. They contend that the replacement of labour and natural materials with machinery, fertilizers, hybrid seeds and agro-chemicals are two stages of appropriation entailing a different mode of capital accumulation. In addition to describing the means of value appropriation by agro-industrial capital, Van der Ploeg (2009) argues that today's giant food corporations never produce value; instead, they simply appropriate value produced by farmers through reorganizing the production process.

\section{The debate on capital accumulation in the Chinese agrarian society}

The debate on capital accumulation in the agro-food sector has turned out to be key to understanding agrarian change in China. Huang argues that small-scale peasant farms are the main force behind the massive increase in the total agricultural production value over the past three decades in China. Moreover, the diet structure transition and increased food consumption will ensure that peasant farms will survive and further develop by producing high-value agricultural products and by intensifying labour and capital on their farms (Huang 2010, Huang et al. 2012). Following this argument, Huang points out that profit extraction from peasants is taking place in the trading and food processing sectors instead of through farming activities (Huang 2012). In other words, capital accumulation takes place outside the farm, while value extraction occurs in the upstream and downstream agricultural supply chains.

Conversely, another group of scholars discuss the capitalization of agricultural production in China. Yan and Chen examine the dynamics of capital accumulation in rural China, arguing that accumulation in agricultural production is leaning towards capitalization and depeasantization. Top-down accumulation works through "dragon-head" enterprises by vertically integrating farmers in the industrial system; that is, farmers become contract producers. Accumulation can, however, also happen from below through the scaling up of family farms (Yan and Chen 2015). Echoing Yan and Chen's argument, Sun refers to peasant differentiation in a rural town in southern China. According to him, several capitalist agricultural enterprises emerged due to land consolidation encouraged by the local government. The result is that small-scale peasants lease out their land and labour on large farms (Sun 2015).

The debate on the capitalization in China's agriculture and food sector following the aforementioned two classic traditions in agrarian studies is of great significance for understanding the relation between capital and peasantry in the agricultural modernization process. However, current studies on accumulation in the agro-food sector are also limited to two theoretical trajectories. One theoretical stream focuses on accumulation within agricultural production - the emergence of capitalist farms and the agricultural labour force. The other concerns capital accumulation by agribusinesses by making peasant farms the object of value exploitation.

The new accumulation strategies in China's agro-food sector 
The discussion in this chapter is based on the two perspectives of capital accumulation in agro-food production. Through an in-depth case study of the sugar industry and the sugarcane production sector in southwest China, new accumulation strategies in the agro-food sector could be observed. The current accumulation activities in China's sugarcane production sector and sugar industry have blurred the boundary of the two analytical viewpoints, giving rise to the identification of three distinct accumulation strategies: agro-technification, food politicization, and land speculation.

First, agro-technification refers to the acceptance and application of new technologies in the sugarcane production process. Sugar companies guide sugarcane farmers to accept new seeds and film-mulching techniques in cane production, and to apply new technology in the extracting process to obtain more valuable products from sugarcane. The introduction of new technologies has created a restructuring of costs and benefits to be shared between the sugar companies and cane farmers. Second, food politicization refers to extensive state intervention in the food market. The Chinese state emphasized the political significance of sugar in its national food security strategy. Thus, Chinese sugar companies can rely on state power to continue further accumulation activities through direct resource redistribution and administrative intervention in trade. The third strategy is land speculation. Within the sugarcane-planting project, which is guided by the governmental ideology of agricultural modernization, land is used by speculators as a material medium to raise capital through the modern finance system.

The following sections elaborate on the three accumulation strategies. The analysis is based on empirical data collected during three periods of fieldwork between 2014 and 2016 in Dongmen Town, a sugarcane-growing town in southwest China, which is briefly introduced in the following section.

\subsection{Recent changes in Dongmen Town's sugarcane production sector}

Dongmen Town is one of the typical rural towns in China's sugarcane production zone where local peasants' livelihoods heavily rely on the growing of sugarcane. It is under the jurisdiction of Fusui County in Guangxi Province, located on the border of southwest China and Vietnam. Sugar manufacturing is the mainstay industry in Fusui County and therefore it is also the main source of governmental fiscal revenues. The total farming land ${ }^{47}$ in this town amounts to around $200,000 \mathrm{mu}^{48}$, of which $189,000 \mathrm{mu}$ is used for sugarcane cultivation.

The popularity of growing sugarcane dates back to the turn of the century, when several changes in the region's social-economic background occurred. Firstly, sugar mills changed hands from the state to private capital, bringing them with greater capital investments required to update the crushing and refining equipment of the sugar mills. As a result, the crushing capacity of the sugar mills was augmented. Secondly, due to the increased demand for sugarcane, an administrative regulation system locally called the "cane zone system" was

\footnotetext{
${ }^{47}$ In China, rural land is categorized by and regulated for different usages, for example farming land, forest land, or construction land. Legally, forest land cannot be used for farming activities, and vice versa.

${ }^{48} \mathrm{Mu}$ is a Chinese measurement unit, with 1 hectare equalling $15 \mathrm{mu}$.
} 
introduced to direct sugarcane selling and purchase activities according to zones. An official document (Guangxi Planed Economic and Trade Commission 2002 [No. 560]) shows that the sugarcane planting area in Guangxi Province is divided into different zones, with each zone having only one assigned sugar mill. Trans-zone selling and purchasing activities have been banned, except under some special circumstances where the local governments give permits. The initial goal of this system was to avoid economic and social instabilities that might be caused by intensified competition among the sugar mills related to purchasing sugarcane. On the other hand, the sales channel of sugarcane is secured and therefore peasants prefer to grow sugarcane instead of other crops. The third and most important reason for an increase in the popularity of sugarcane growing is China's increasing demand for sugar, which has led to a price boom of both sugar and sugarcane on the domestic market.

Generally, a sugarcane zone covers five to eight rural towns, depending on the crushing capacity of the sugar mill. Dongmen Town is part of the largest cane-planting area in the cane zone of the Dongmen-Nanhua Sugar Company. This sugar company is one of many affiliated companies of the Nanhua Sugar Industry Group, which includes all types of businesses relating to sugar across seven Chinese provinces. Within Guangxi Province alone it owns 15 affiliated sugar companies. Given the fact that the sugarcane selling and purchasing channels are targeted under the cane zone system, the relation between cane peasants and sugar companies bears semblance to contract farming. However, the key difference is that peasant households still have the autonomy to switch to other crops whenever they desire to, since no real contract exists between them and the sugar company. Therefore, since 2012, when a drop in the sugar price on the global market heavily influenced the domestic sugar market, peasants gradually turned to growing other crops.

As a response to the low motivation for growing sugarcane among peasants, the Guangxi Province government launched a five-year "double-high"49 project in 2013, which fits into the central government's national food security and agricultural modernization framework. According to official documents, the project aims to develop 5 million mu of sugarcane production land to meet large-scale ${ }^{50}$ and mechanized production standards, lead to improved cane varieties, and include modernized irrigation systems (Guangxi Government 2013 [No. 36], 2014 [No. 15]). Under the well-funded project, large governmental subsidies are invested in land consolidation activities, large agro-machinery, improved varieties of cane seed, specific agro-technical materials, and modern irrigation techniques including drip irrigation, underground irrigation, and water-fertilizer-integrated irrigation.

Due to the project, two trends in sugarcane production are evident in Dongmen Town. Firstly, the farming company appeared on the scene and developed large sugarcane plantations. The plantation built up by the Kaili Agricultural Investment Company ${ }^{51}$ in 2014 covers 6,300 mu of farmland across two villages and involves nearly 180 households. In fact, with the support

\footnotetext{
49 "Double-high" refers to a high sugarcane yield and a high sugar content.

50 The minimum land scale according to the "double-high" project is $200 \mathrm{mu}$.

51 Agricultural investment companies or farming companies refer to the companies that emerged recently in China with the policy support as 'industrial and commercial capital going to the countryside'. These companies transfer land of rural households and directly engage in agricultural production activities.
} 
of the "double-high" project, the Kaili Agricultural Investment Company has invested in several large plantations in other sugarcane production zones in Guangxi Province. Secondly, the sugar company has become the intermediary body between the local government and farmers. Government subsidies for "modernizing" sugar production, including for improved varieties of cane seed, agro-technology, and large agro-machineries, are administered through the sugar company.

Consequently, two main modes of sugarcane production currently exist in Dongmen Town: sugarcane production by the massive number of small farming households, and that of the emerging large-scale plantations. The farms ${ }^{52}$ owned by peasant households and operated mainly by family labour range in size from $20 \mathrm{mu}$ to around $120 \mathrm{mu}$, but the newly-built cane plantations invested in by the farming company usually cover thousands of mu of farmland. Skilled labourers needed for operating machines are hired all year around on the plantations. Within this context, the following sections will discuss the new strategies of capital accumulation in the agricultural production sector, as has recently occurred in China.

\subsection{Agro-technification: cost-shifting and the redistribution of harvests}

The relation between technology and capital accumulation in agriculture has been widely discussed in the social sciences. Kenny (1986) documented the evolving university-agroindustry relation in terms of the development of modern biotechnology, focusing particularly on how the agricultural sector has become one of the main sectors for biotechnology application. Companies invest in biotechnology research in order to conceive new products and techniques (such as technology stimulating superovulation in cattle farming and plant diagnostic technology), which can open new markets and create significant profits.

Seed is the most noticeably commodified natural material in farming activities. Kloppenburg (1988) reviewed the history of the way in which the biotechnology industry has established the plant breeding business and gained control of seeds, pointing out that the objective of modern plant breeders is to produce new seed varieties that can be sold at a profit, instead of aiming to reach some sort of social optimum. This reveals the imperative of profitability in a capitalist system. The most elaborate explanation of modern technology and capitalist development of agriculture comes from Goodman and Sorj (1987), who argue that the industrial appropriation of the rural production process (mechanical, chemical and genetic innovations) and the industrial substitution of rural products (large-scale food processing and preservation processes; artificial raw materials) are the two patterns of capital accumulation in the modernization process of the agro-food system.

These studies explain how modern companies, by applying new technologies based on scientific research, attempt to capitalize the agriculture production and food processing sectors. Put differently, industrial capital accumulates through creating new technological

\footnotetext{
52 The discussion centers on land used for agricultural farming activities only; land used for forestry activities is excluded.
} 
products for agricultural and food production. The wider impact of this process on peasants is the rising cost of food production. Shiva (2000) states that:

....as farming is transformed from the production of nourishing and diverse foods into the creation of markets for genetically engineered seeds, herbicides, and pesticides... as farmers are transformed from producers into consumers of corporatepatented agricultural products...the global economy becomes a means for the rich to rob the poor of their right to food and even their right to life (Shiva 2000: 7).

This section further explores capital accumulation through science and technology in the agro-food production sector, which relates not only to the commoditization of agricultural inputs, but also to the unequal bearing of the increased cost of applying technology in agricultural activities and the unequal sharing of increased harvests between peasant farming and the food industry as a result of the application of new technologies. The former can be referred to as "cost-shifting" by food companies and the latter as the "redistribution of harvests" between peasants and food companies.

China's "double-high" project aims to achieve a high sugarcane yield on farms and a high percentage of sugar content in sugarcane primarily by means of improving sugarcane varieties and through the introduction of new film-mulching technique. The Chinese government stipulates that subsidies are to be made available only in cases where all the above-mentioned standards are met (Guangxi Government 2014 [No.89]). Peasant farms are excluded from the massive project subsidies due to their farm size and mechanization level. Nevertheless, they were strongly advised by the sugar company and the local government to use the improved cane varieties and to apply the film-mulching method. Agricultural technicians from the government or the sugar company organized training sessions to convince peasants of the benefits of the new seeds and film-mulching method.

However, new seeds and mulching technologies are costly. Traditionally, cane farmers have a stockpile of cane seeds and only purchase seeds when their stores have been depleted.

Switching to new seeds entails great capital expenditure for peasant farmers, which implies an increase in production costs. In the 2013/2014 financial year, the market price of the improved varieties of cane seed was 470 yuan/tonne, while that of the traditional varieties was 440 yuan/tonne ${ }^{53}$. The cost of film mulching is also quite substantial. Sugarcane requires 2.5 to 3.5 kilograms of plastic film for one mu of land, and the film price amounts to 25 to 35 yuan per kilogram. Hence, the material cost alone is around 90 yuan per mu, which does not include the cost of mulching activities by either tractor or labourer.

To push for the change, the sugar company and the local government resorted to both economic incentives and administrative means. As an economic incentive, the sugarcane company offered peasants 30 yuan per tonne more for the improved seeds as compared to the price of regular cane varieties, while peasants who applied for the film-mulching technology could receive a subsidy of 60 yuan per mu from the second year of the ratoon cane. 53 The cane seed and the cane sold to the factory fetch similar prices in the same year. Besides, one mu of land
requires 0.8 tonnes of cane seed. 
Administratively, local government control has ensured that regular sugarcane varieties have gradually dropped off the market; film-mulching technology was propagated by the local government as part of their political agenda.

The four improved varieties of cane seed that are offered 30 yuan more per tonne of the purchasing price by the sugar company are GT 29, GT 42, YT 93/159, and LT 05/136. According to the official report, the new varieties are-compared with CK 22, the most popular traditional cane variety - early to mature and lodging-resistant. They also have higher degrees of sugar content, and three out of four varieties have relatively higher yields according to tests. Because of the harvest being earlier due to the Early-to-mature cane, the production is, in sugar factories, immediately efficient, whereas with the traditional cane variety the sugar factory would run inefficiently during the first month(s) given the little quantity of sugar cane available.Besides, the lodging-resistant character is developed for harvest machines suited for large cane plantations.

These measures have had remarkable outcomes. According to the local government, in the past decade the adoption rates in Dongmen Town of improved seed varieties and filmmulching technology exceed $50 \%$ and $80 \%$, respectively. Cane farmers believe that they can have a better harvest by investing in the new seeds and film-mulching technology, as promised by the agricultural experts and technicians. Plausibly, cane from improved varieties can fetch a higher price and film mulching also increases yield. However, the new technologies enable the redistribution of costs and benefits among the sugar company and the cane farmers.

The pursuance of a higher sugar content or higher cane yield is complex, since the sugar company and cane farmers have different desires in this respect: the sugar company wants a higher sugar content rather than simply a higher yield, because it gains profits from sugar extraction, but has to pay for sugarcane by weight. For cane farmers, a high yield is desired. The sugarcane variety database of the Guangxi Academy of Agricultural Sciences together with reports provided by the Guangxi Science and Technology Department show that the cane yields (tonnes/mu) of these improved varieties range from lower to a bit higher (maximum $+11 \%$ ) as compared with CK $22^{54}$. However, the quantity of sugar extraction from one mu of land (tonnes/mu) can increase from $14 \%$ to $21 \%$ when the improved varieties are applied (GAAS 2012, Huang et al. 2016). Linking up increased rates of yield and sugar extraction with market prices clearly shows who profits from the change. In the 2013/2014 financial year, the average sugar price was 5,700 yuan/tonne and the corresponding sugarcane price was 470 yuan/tonne for the improved sugarcane varieties. Even if we choose the highest increase rates for both cane yield and the expected quantity of sugar, peasants would only receive an additional $232.65(=470 * 4.5 * 11 \%)$ yuan/mu, while the sugar company would receive an extra $598.5(=5700 / 2 * 21 \%)$ yuan $/ \mathrm{mu}^{55}$

\footnotetext{
54 The yield increase rate of GT 29 is lower than that of CK 22.

55 The average cane yield for peasant farms is 4.5 tonnes/mu. On average, 8 tonnes of sugarcane can yield 1 tonne of sugar, which means that producing 1 tonne of sugar requires two mu of land for sugarcane growing.
} 
However, the costs of the changeover to the improved varieties are incurred at the peasant household level. Scientific knowledge of the film-mulching technology was distorted when introduced to the cane farmers. Film mulching increases yield only for the first-year cane seedling, while cane farmers were told that the primary advantage of using film-mulching technology is an overall increased yield. The logic is that the ideal environment created by covering cane seed with film can speed up the germination process and produce strong seedlings. The cane density in a piece of land is finalized in the first year and will not see obvious change in the following years. In the years afterward, the main function of film mulching is to increase the sugar content instead of boosting the yield. However, the agricultural technicians misleadingly informed cane farmers about the yield-increase effect when promoting this technology. Besides, the subsidy from the sugar company covers less than two-thirds of the material cost of film mulching and is only assigned from the second year of the ratoon cane. Therefore, while the cane farmers bear the increased cost of the new technology, the sugar company secretly gains more benefits.

The second objective of harvest redistribution through technology is to produce multiple products from sugarcane. With technology development, the agricultural product processing industry can cover a wide range of business fields. Traditionally, the products derived from sugarcane crops have been limited to food, fodder, wood, wool, and fibre. However, recently the high-value products extracted from agricultural crops have come to include bioenergy, electric power, pharmaceuticals, cosmetics, chemicals, and organic fertilizers. Borras et al. refer to crops with such character as 'flex crops and commodities', which include 'crops and commodities that have multiple uses (food, fodder, fuel, industrial material) that can be, or are thought to be, flexibly inter-changed' (Borras et al. 2014). However, here the term "all-in-one crops" is used, because these crops are not in an either-or relation, but coexist. For instance, sisal can be transformed into fibre, saponin, cosmetic ingredients, and medicine components.

The "all-in-one" economic benefits are determined not only by the character of the crops, but, more importantly, by high technology. Currently, most crops can be processed into multiple products through one processing line, and sugarcane is a typical crop for deriving maximum economic benefit. The sugar company obtains two primary products after crushing the cane: molasses and bagasse. Sugar, the main product, is first cleared from molasses. In the next step the "waste molasses" are fermented into monosodium glutamate, yeast, a nutrient medium, lysine, and other acids. Bagasse is used primarily as a fuel for operating the entire processing line, but only part of the total amount of bagasse is used for this purpose; a large amount of bagasse is also used for generating electricity and producing pulp. Furthermore, the sludge left from the burning of bagasse is turned into organic fertilizer for crops and sold back to peasants. While it is difficult to calculate the total value of the by-products from one tonne of sugarcane, it is clear that these by-products are mostly high-value products, for instance, monosodium glutamate is around 15 yuan/kilo, bagasse-based organic fertilizer is around 200 yuan per truck (around 10-13 tonnes). 
Given that sugarcane can produce so many high-value products, it is surprising to see that the purchase price of sugarcane is only determined by the market price of sugar ${ }^{56}$. From 2012 onwards, the sugar price both on the global market and on China's domestic market has fallen. As a result, the basic purchasing price of cane dropped from 500 yuan/tonne in the $2011 / 2012$ financial year to 400 yuan/tonne in the 2014/2015 financial year. The low cane price made cane farmers' life more difficult, considering the money inflation in the economy and the increased costs of cane production. According to the data from National Survey of Cost-Incomes of Agricultural Products in 2014, the cash income generated by growing sugarcane was +683.33 yuan/mu, but the net profit was -150.04 yuan/mu (CSMNSCIAP $2014)^{57}$. While cane farmers suffered from the low cane price due to the stagnation of the sugar market, the sugar company still maintained the entire industrial chain by lowering the cane purchase price and gaining substantial profits from by-products. Therefore, sugar companies attempt in different ways to prevent farmers from resorting to other crops. The basic problem in the technology promotion is the unequal distribution between the cane farmers and the sugar company regarding the increased production cost and gained harvests. It is clear that agricultural technification has become a covert way of capital accumulation that shifts the technological cost to farmers and the gains to food processing companies.

\subsection{Food politicization: the state and agro-food capital nexus}

Clapp and Fuchs (2009) advanced the literature on food governance with their analysis of the relationship between agri-food corporations and food governance. They proposed an instrumental-structural-discursive framework to identify the political role and the power construction processes of transnational corporations in the arena of global food governance. Their work is critical for understanding the interaction between the global food system and transnational private capital. To some extent, their explanation corresponds to Harvey's accumulation analysis of the "transnational capitalist class" in the neoliberal global economy (Harvey 2003: 183-189). However, this global political economic view of agri-food corporations does not fully explain the political and economic processes related to food governance at the national level.

This section thus aims to understand how agro-food capital and the state interact to shape a certain framework of food governance at the national level. This includes two guiding questions: how do agro-food corporations make use of state power in order to continue accumulation activities at both the national and transnational level; and how can the state reinforce its political power related to national food governance through its support of accumulation activities of agro-food capital? This section shows the allied strategy of capital accumulation and state governance in the neoliberal economy era. This must be distinguished

\footnotetext{
56 A price linkage mechanism has been applied for many years on the sugar and cane market in Guangxi Province. The government sets a basic purchasing price for cane based on a predicted market price of sugar every year. The fluctuation linkage rate is $6 \%$, which means that the final purchasing price of cane can increase or decrease by $6 \%$ of the actual market price of sugar.

${ }^{57}$ The net profit is the margin between cash income and the market price of family labour and self-owned land. It is a way of looking at whether growing a particular crop is profitable by comparing the value of the crop, land, and labour in a certain economic market.
} 
from the state-driven accumulation for economic development - the so-called developmental state (Johnson 1999).

In the case of China, the transition of the two historical stages started in the 1990s, when the Chinese economy entered into a privatization and liberalization stage as the result of the "open-up" policy and domestic economic reform. However, the power of both international financial capital and domestic private capital were submissive to the Chinese state in performing their economic activities (Harvey 2007: 122-123). In the sugar industry sector, the decisive change took place in 1993 when the Thai MitrPhol Sugar Group acquired five stateowned sugar mills in Guangxi Province and founded the Nanning East Asia Sugar Company in China. The company expanded rapidly and soon became the largest sugar producer in China. In addition, the Yangpu Nahua Sugar Group was officially registered in Hainan Province in 1997 by domestic private capital and later expanded its activities to Guangxi Province and other provinces. Therefore, over the past two decades, private corporations have dominated the Chinese sugar industry, although a few state-owned farms are still engaged in sugar production activities.

The Chinese sugar market was further liberalized after China accessed to the WTO in 2002. China's accession agreement stipulated that, following the phase-in period of six years, the sugar import quota would be over 1.9 million tonnes, and the in-quota tariff and out-quota tariff were set at $15 \%$ and 50\%, respectively (World Trade Organization 2001). It is clear that the low sugar import tariffs pushed the Chinese sugar sector into the liberal global market. This is even clearer when making a comparison between China's conservative import tariffs for grain and the high sugar import tariffs of most member countries forming part of the $\mathrm{WTO}^{58}$.

The hasty opening of China's sugar market to the global sugar market with its low import tariffs did not immediately show a negative impact on the domestic sugar industry after the end of phase-in period, because the global food market encountered dramatic price increases at the time (in 2007 and 2008) (Von Braun 2008). However, with the waning of the global food price crisis, the competitive disadvantage of domestic sugar companies came to light. From the 2010/2011 season onwards, the domestic sugar price has declined over six years due to the excess supply in the global sugar market. The low sugar price led to the bankruptcy of small private sugar companies as well as to a substantial reduction in the sugarcane planting area. Thus, capital in the Chinese sugar industry was facing an accumulation crisis.

The countermeasure strategy of these sugar companies was to shift the problem onto the political agenda. Originally, "food security" in China was equated to grain security. As Ghose (2014) indicated, cereal grain production was prioritized in the restructuring of the agricultural sector during China's economic reform period in the 1980s (Ghose 2014). In 1996 Chinese Premier Li Peng, at the second World Summit on Food Security, promised that

\footnotetext{
${ }^{58}$ It is reported that the average sugar import tariff of WTO member countries is $97 \%$. The average index among developed member countries, developing member countries and the underdeveloped member countries are respectively $122 \%, 55 \%$ and $167 \%$. A report from CI Consulting, "Adjustment of sugar import tariff came into focus". Available from: http://www.ocn.com.cn/jinrong/201609/bbpof29104133.shtml [accessed on 22 ${ }^{\text {nd }}$ March 2017] [in Chinese]
} 
China would rely on domestic resources to achieve mainly grain self-sufficiency. To this day, the grain self-supply strategy is the national guiding policy for agricultural production ${ }^{59}$. Furthermore, cotton and oil are also considered as strategic goods in the Chinese agro-food policy discourse. Sugar was never considered a dietary product of political significance.

The enduring sugar price fall drove sugar companies to lobby the Chinese central government since 2012. They argued that sugar should be prioritized alongside grain, cotton and oil in the national agro-food security strategy. Sugar security is about the domestic sugar supply and the sugar or sugar-based food industries, but it is also directly related to the income of China's 40 million sugarcane farmers (Ministry of Agriculture of the PRC 2014). Sugar companies' lobbying efforts were successful and garnered the attention of the central government. Under the instruction of the State Council, an official document titled "Development Plan for the Main Sugarcane Producing Area (2015-2020)" was issued in 2015. The document clearly states that from that point onward, the development of the domestic sugar industry would form part of the national food security strategy framework. As with many agricultural projects, substantial investments were made in infrastructure, science-technology, and machinery in the sugar and sugarcane production sector (National Development and Reform Commission 2015). Following this idea, a "double-high" project was launched. The project contains four components: land consolidation, improved cane varieties, mechanization, and irrigation infrastructure. For the modules relating to new seeds and machines, sugar companies carried out the application of governmental subsidies to project practices. Clearly, the project brought direct benefits and power to sugar companies.

Besides directly allocating resources to sugar companies, political influence also spans business and trade activities. Sugar import regulations faced change: before 2010, the annual sugar import volume at 1.95 million tonnes was within the official quota of the low-tariff rate $^{60}$. From 2011 onwards, the yearly import volume of sugar increased rapidly: from 2.92 million tonnes in 2011, to 3.75 million tonnes in 2012, to 4.55 million tonnes in 2013, to 3.48 million tonnes in 2014, and, finally, to 4.84 million tonnes in $2015 .{ }^{61}$ By 2015, imported sugar thus comprised more than one-fourth of the total domestic sugar supply, and this proportion keeps rising due to the low price of raw sugar on the global market. Initially, the China Sugar Association devised regulations for domestic sugar refineries regarding the restriction of the import volume of raw sugar (Yunnan Sugar Web 2014). However, the commercial rules were not capable of controlling the profitable sugar trading business. By late 2014, the central Chinese government introduced a new registration system for sugar import that is applied with the high-tariff rate (Reuters 2014). Although the Commerce Ministry did not publicly motivate the reason for the introduction of the registration system, it is clear that this new system can buffer against sugar imports.

\footnotetext{
59 QStheory. 2015. Analysis of China's food security and supply-demand condition. Available from: http://www.qstheory.cn/economy/2015-02/15/c_1114379549.htm [accessed on 30 ${ }^{\text {th }}$ March 2017] [in Chinese] 60 According to the China-WTO agreement, Chinese government implies low-tariff rate (15\%) to the import quota of 1.95 million tonnes and high tariff rate $(50 \%)$ without the quota.

61 The data is from National Bureau of Statistics of China.
} 
The sugar companies further argued that control of sugar importation was necessary but not sufficient, since the low import tariff was the main problem; the global average for sugar tariffs is $97 \%$, while the Chinese sugar tariffs is $15 \%$ for quota import and $50 \%$ for out-ofquota import (Dominique 2015). Thus, the Guangxi Sugar Association in 2016 officially applied for an investigation into the damaging effect of sugar importation on the domestic sugar industry. The Ministry of Commerce then commenced with an investigation into the sugar tax; as a result, the current China-WTO agreement on sugar tariffs was adjusted (Ministry of Commerce, PRC 2016). Hence, after obtaining subsidies in the production sector, the sugar companies successfully received support from the state to intervene in trade activities. However, the "from-capital-to-the state" intervention approach is only one of two components of the state-capital interactive process.

The other constituent of the state-capital interaction is the "from-the state-to-capital" intervention, which operates through the expansion of state-owned food enterprises. While the state can reinforce its political power on food governance through its support for domestic food companies, private capital investment cannot always adhere to the national food security plan. Therefore, state-owned food enterprises started to encroach on the sugar business when the domestic sugar market crisis began. COFCO and the Bright Food Group are two such state capital-controlled food companies ${ }^{62}$. In 2009, the Bright Food Group acquired a 60\% share of the Yingmao sugar company - the largest sugar company operating in Yunnan Province (the second largest sugar-producing province in China), which was previously fully financed by foreign capital ${ }^{63}$. The Bright Food Group then continued its acquisition strategy and merged with the Guangxi Feng Sugar Company - a large private sugar company in Guangxi Province - in 2014. COFCO on the other hand since 2011 more aggressively asserted its dominance through business acquisition or new projects. Table 1. shows their development trajectories in the sugar industry.

Table 1. Chinese state-owned agro-giants and their expansion in the sugar sector in recent years

\begin{tabular}{|c|l|l|l|}
\hline $\begin{array}{c}\text { State-owned } \\
\text { agro giant }\end{array}$ & $\begin{array}{l}\text { Acquisition } \\
\text { period }\end{array}$ & Name of merged/newly-formed sugar companies & $\begin{array}{l}\text { The previous } \\
\text { capital owners } \\
\text { or new projects }\end{array}$ \\
\hline \multirow{2}{*}{$\begin{array}{c}\text { COFCO } \\
\text { (-TUNHE) }\end{array}$} & 2011 & Tully Sugar Limited & Foreign capital \\
\cline { 2 - 4 } & 2011 & $\begin{array}{l}\text { COFCO sugar manufacturing company in Guangxi } \\
\text { Province }\end{array}$ & Newly built \\
\cline { 2 - 4 } & 2014 & Caofeidian Sugar Refinery & Newly built \\
\hline
\end{tabular}

62 COFCO belongs to the Central State-owned Assets Supervision and Commission (the Central SASAC), while Bright Food Group is under the Shanghai State-owned Assets Supervision and Commission (the Shanghai SASAC). Information from their websites: http://www.cofco.com/cn/index.html; http://www.brightfood.com/cn/about.aspx?Class_ID=11 [accessed on 11 $1^{\text {th }}$ May 2017]

63 Yunnan website. 2009. Bright Food acquired 60\% stake of Yunnan Yingmao Sugar Company. Available from: http://finance.yunnan.cn/html/2009-08/19/content_876476.htm [accessed on 11 1 th May 2017][in Chinese] 


\begin{tabular}{|c|l|l|l|}
\hline & & (largest sugar refinery of imported raw sugar) & \\
\cline { 2 - 4 } & 2014 & Sugar mills of Noble Agri Limited in Brazil & Foreign capital \\
\cline { 2 - 4 } & 2014 & $\begin{array}{l}\text { China Huafu Trade \& Development Group Corp } \\
\text { (responsible for the national sugar reserve) }\end{array}$ & State-owned \\
\cline { 2 - 5 } & 2014 & $\begin{array}{l}\text { Sugar business module in China National Sugar and } \\
\text { Alcohol Group Corp } \\
\text { (the largest sugar sales and marketing company in China) }\end{array}$ & State-owned \\
\hline $\begin{array}{c}\text { Bright Food } \\
\text { Group }\end{array}$ & 2009 & $\begin{array}{l}\text { Yingmao Sugar Industry Company } \\
\text { (the largest sugar company in Yunnan Province) }\end{array}$ & $\begin{array}{l}\text { Foreign capital/ } \\
\text { domestic } \\
\text { located }\end{array}$ \\
\cline { 2 - 4 } & 2014 & $\begin{array}{l}\text { Guangxi Feng Sugar Company } \\
\text { (one of the largest sugar companies in Guangxi Province) }\end{array}$ & Private capital \\
\hline
\end{tabular}

Note: The table is synthesized by the author based on information from the COFCO and Bright Food Group websites and from various news reports.

The direct result of the state-owned capital expansion has been the tendency toward stateowned capital monopoly in the domestic sugar industry. COFCO and the Bright Food Group quickly secured positions at the top of the list of sugar-producing companies in China. Besides, the stated-owned sugar companies are assigned $70 \%$ of the low-tariff import quota ${ }^{64}$. Moreover, COFCO controls most of the domestic sugar marketing channels. This change also led to the restructuring of capital power in the sugar industry and trade; that is, the rise of state-owned capital and the decline of foreign and domestic private capital. In turn, capital structural adjustment in the sugar industry sets the ground for the "double-high" sugarcane project. As the manager of Dongmen-NanHua sugar company said:

We (as domestic private capital) respond to the governmental policy and positively get involved in the "double-high" project. We also contribute to the national sugar security goal. COFCO and other state-owned sugar companies are more active in the project because they have abundant capital from the state. Besides, it is their responsibility to achieve sugar security goals. However, the East Asia Sugar Company is not participating well in the sugarcane project. They do not follow the instructions of the government about investing in land consolidation and sugar plantations. This is because the boss is Thai; he is not Chinese. (personal interview, 2 January 2017)

In both the "from-capital-to-the state" and the "from-the state-to-capital" interventions, agrofood capital cannot continue its accumulation activities without the support of the state. Similarly, the state cannot ensure its political authority and economic security without

64 According to the sugar import regulation of the Ministry of Commerce, PRC., 70\% imported sugar with low tariff is distributed to state-owned enterprises. 
collaboration with capital groups. By framing the stagnation of domestic sugar production as a national food security problem, private capital acquired both natural resources and governmental subsidies to fund its activities. Conversely, through its support for the agro-food companies, the state can ensure that its strategy targeted at national food governance is carried out. In countries like China, the state can govern the domestic agricultural production and food industry through specific market activities - by using state-owned capital to interfere in the agro-food sector.

\subsection{Land swindle: land consolidation activities for obtaining agricultural resources}

Building modernized sugarcane plantations is one of the principal objectives of the "doublehigh" project that aims to reduce the sugarcane production cost as well as to ensure a stable sugarcane supply to the sugar mills. According to the government, four actors in the sugarcane sector are eligible for governmental subsidies if they expand cane plantations beyond $200 \mathrm{mu}$. They are: sugar companies, agricultural investment companies, cooperatives, and scaled-up family farms (Guangxi Government 2014). For these actors, merging pieces of land owned by scattered peasant households is key for engaging in farming activities and accessing agricultural subsidies. However, land consolidation by agricultural investment companies shows the aggressive accumulation strategy of taking advantage of the agricultural subsidy system. This accumulation activity can potentially undermine national food security and the livelihoods of local peasant households.

Land consolidation undertaken by agricultural investment companies is usually a swindle game rather than a production activity. To understand this, it is necessary to reflect on the development of the Kaili Company ${ }^{65}$. Due to the domestic sugar industry crisis, sugar companies and local governments were put under pressure from corporate profits and tax revenues in the 2010/2011 crushing season. Seizing the opportunity, Huang, the initiator of the Kaili Agricultural Investment Company, promoted the mode of large plantation production to the local government, which reported to the Guangxi provincial government that this mode of production is the solution to local economic hardship. The provincial government further developed the idea into a blueprint of the so-called "second prosperity of the sugar-cane industry", which fits into the sugar security plan of the central government. Therefore, corporate plantations became the main highly subsidized production mode in the "double-high" sugarcane project. Having gained policy support, the Kaili Company started land consolidation activities. Land consolidation is based on land (operation right) transfer under the Chinese Household Responsibility System; that is, renting land from the farmers. Between 2013 and 2016, eight sugarcane plantations have successively been created in the cane production zone in Guangxi Province (see Table 2 below). In fact, the sugarcane plantation in Dongmen Town is only one of the eight cane plantations under the operation of the Kaili Company.

\footnotetext{
65 Since the agricultural investment companies are very sensitive about their background and other information, the author had tried very hard to get a credible and complete picture of Kaili Company. The author stated the situation of data collection here in case there is any minor unmatched description in the chapter.
} 
Table 2. The expansion of sugarcane plantations implemented by the Kaili Company

\begin{tabular}{|c|c|c|}
\hline $\begin{array}{l}\text { Location of cane } \\
\text { plantations }\end{array}$ & Acreage of each expanded plantation & Completion year \\
\hline Zhanjiang & $4,000 \mathrm{mu}$ & 2013 \\
\hline \multirow{3}{*}{ Nanning-Wuming } & $3,450 \mathrm{mu}$ & \multirow{3}{*}{2013} \\
\hline & $8,000 \mathrm{mu}$ & \\
\hline & $3,700 \mathrm{mu}$ & \\
\hline Liuzhou & $600 \mathrm{mu}$ & 2014 \\
\hline \multirow[t]{3}{*}{ Chongzuo-Fusui } & $\begin{array}{l}\quad 6,800 \mathrm{mu} \\
\text { (Palou-Pabai plantation, in Dongmen } \\
\text { Town) }\end{array}$ & 2014 \\
\hline & $6,255 \mathrm{mu}$ & 2015 \\
\hline & $4,200 \mathrm{mu}$ & 2016 \\
\hline
\end{tabular}

Source: Data obtained from an interview with one of the managers of the Kaili Company. Some of the plantation acreages are approximate figures.

The accumulation mechanism is very bold. According to one key interviewee ${ }^{66}$, the Kaili Company is, like any other agricultural investment company, a "fund-extracting company". The company registered itself without substantial capital; on the contrary, it was founded for raising capital. According to the subsidy rule of the "double-high" project, one can get 2,478 yuan/mu construction cost from the government for establishing a modern sugarcane plantation. Thus, the Kaili company can receive $(4000+3450+8000+3700+600+6800+$ $6255+4200) * 2478=$ = 91,698,390 yuan for its eight plantations. Moreover, to achieve government performance and accomplish the local targets of the "double-high" project, the local government placed pressure on the sugar companies and the banks to provide loans to the Kaili Company with very low interest rates. The known amounts are 12 million yuan from the Dongmen Nanhua Sugar Company and 10 million yuan from the Nanning East Asia Sugar Company. The loan amounts from the local China Agricultural Bank are not clear. According to information from another key interviewee, the government sponsored a substantial part of the input cost of the plantations. The Guangxi Sugarcane Research Institute offered free cane seeds to the Kaili Company and the government also subsidized large agricultural machines and other production materials (like pipes and plastic films). As the interviewee said, 'Kaili started with very little money, but now it has already 100 million in assets.' (personal interview, 23 December 2016)

The land consolidation activity is unsustainable in many respects: First in terms of the impact on the local economy, land transfer and concentration placed pressure on the local villagers' livelihoods and income and caused tensions. The villagers have doubts about the Kaili Company as regards its capacity to pay the land rent and its capacity to complete the contract period. The tension around land rent caused real conflicts in the summer of 2016 when the local villagers did not receive land rent from the Kaili Company at the agreed time. They protested in front of the building of the Kaili Company and at the township government's office. When they received no response, they forcefully stopped production activities in the

66 Since the topic of land speculation is very controversial, the interviewees asked for full anonymity. 
plantation and locked the gate of Kaili's machinery storage facility. After two months, the Kaili Company paid the villagers after the county government pushed the local China Agricultural Bank to offer a loan to Kaili. However, because of the conflict, the plantation missed sugarcane's best growing season. The doubt about whether Kaili can abide by the contract has not yet resulted in any action, but the villagers remain worried about it. Almost every interviewed farmer echoed the words of one farmer, who said:

Who knows, one day the boss may take the money and run away and leave the chaos to us. If it happens, we will get nothing from the land for the next two to three years, because it will take at least two years to redistribute the land to each household. (focus group interview, 2 January 2017)

Second, unemployment is a feature of the local societies where cane plantations are established. Gambling became more popular in the local societies due to high unemployment rates, and gambling groups can be found at every corner in these villages. Since the large plantations can only hire a very small number of labourers, the majority of the villagers that rent out their land have become unemployed. Most of the local villagers have been farmers for their entire lives and have little working experience in cities. As several young men said,

We have no college diploma, nor professional skills; who will hire us? We tried to work in cities before, but we spent more money than we earned. So, our parents asked us to come home and grow sugarcane. But since we rent out our land, we just wait for the land rent and enjoy life. (personal interview, 26 December 2016)

Contrary to those who spent their time gambling, the families with greater economic burdens to bear, such as to ensure their children's education, arrange filial marriages or combat serious diseases, seek additional income sources. These villagers are mostly opposed to land transfer and the Kaili Company, since they can benefit more from self-farming than from land leasing. They are anxious and resentful about the current situation and the future. One of these farmers said that

...compared with the land rent, I can get a double to triple the income from the land if I work hard by myself. Now I have to go to our county centre to look for jobs. I will do anything that people offer me-I will become a guard or dustman, etc. I am old; it is not easy to find [a job]. But I have two children who are of schooling age." (personal interview, 28 December 2016)

The third unsustainable aspect is the countereffect of large-scale land transfer on national food security. The key issue here is productivity. The government and the Kaili Company claimed that modern cane plantation could increase the sugarcane yield, so that it can lower sugarcane production costs. However, the cane plantations did not provide evidence of higher yields over the past two years. The average yield in the cane plantations was less than 4 tonnes/mu, while the average yield of small farmers is 4.5 tonnes/mu. The manager of the Kaili Company blamed the local villagers' protest action for the low yield in the cane plantations. But, as the local farmers explained, 
...even if there has not been an interference, this mode does not work well. The plantation workers only spray pesticide and weed at the outer part of the cane field; they do not go inside the field. No one works as hard as for their own farm. (focus group interview, 2 January 2017)

Another issue relating to productivity is the output per unit of land. Before the land transfer, farmers intercropped sugarcane with watermelon. Per mu of land, farmers on an annual basis can produce on average 4.25 tonnes of sugarcane and 2.5 tonnes of watermelon. Although the farmers didn't intercrop watermelon in the entire cane field, $30 \%$ to $70 \%$ of the land was planted with the two crops, depending on each household's farming plan. However, monocropping is the popular planting system in the plantations, while the average yield is even lower than that of small farmers. Even if the cane plantations can achieve their yield goal of 6 tonnes/mu - a difficult feat given the current situation - it is still uncertain which farming methods can produce more food. While small farmers choose intensive farming to increase production for an increased income, plantations search for profits based on large-scale land and rough farming ${ }^{67}$. The yield of a particular crop in the plantation mode may but not automatically be higher, but small farms produce more diverse farm products within in their limited land plots. Accordingly, the project goal of achieving food security is seriously challenged by its unrealistic method.

This accumulation mechanism is based on resource extraction, including financial resources and natural resources. It is detrimental to both the national food security plan pursued by the Chinese government and the livelihoods of the local villagers. Furthermore, this accumulation activity is turning into a serial and trans-border land occupation action. Speculators accumulate their initial large capital by extracting agricultural funds in China, where the government currently subsidizes large-scale agricultural production due to the high domestic land and labour prices. But after obtaining the funds, speculators can shift the plantation business to neighbouring countries, where land and labour prices are low. In the meantime, they can declare their limited liability companies inside China bankrupt. As stated by two key interviewees, the boss of the Kaili Company is searching for sugarcane locations in Cambodia, Thailand and Myanmar. In fact, the latest news from the informants residing in Dongmen Town in 2018 reveals that the Kaili Company is bankrupt and that its leader currently resides in Myanmar.

\subsection{Conclusions: an accumulation synergy and the food security issue}

This chapter discussed three strategies of capital accumulation that can be currently observed in the agro-food sector in China. New technologies restructure the distribution of costs and benefits between food companies and farmers. State intervention provides the ideal socioeconomic context for capital to continue its accumulation activities. Land speculation is the

\footnotetext{
67 Rough farming refers to the farming strategy that uses more land but less labour to produce food (it can reduce production costs when the labour price is relatively higher than the land price in the market). The term is borrowed from the concepts 'large and rough farming' and 'small and fine farming' by Huang Zongzhi in Is "family farms" the way to develop Chinese agriculture?. Open Times, 2014 (2).
} 
most unsustainable and fraudulent way of capital accumulation and resource extraction from both nature and financial funds is destructive to the agricultural population and its activities.

Benvenuti argued that the agricultural sector has been shaped by many institutions, including state agencies, agribusinesses, banks, and service providers, and the agricultural producers who live in such an "environment" have been directed what, how, when and why their activities should be conducted. This situation of recent agricultural production echoes the theoretical model of 'Technological-Administrative Task Environment' (TATE) (Benvenuti 1975). The accumulation strategies discussed in this chapter have echoed the TATE analysis. New technologies and state intervention create a new environment in which farmers and nature have lost their prominence in agricultural production. Rather, the new environment takes agricultural production as the process of capital accumulation and state governance, and the activities of the governments and companies have shown an accumulation synergy.

This chapter attempts to show how the new accumulation strategies work; how the strategies defy food security and rural livelihoods; and how the strategies destroy the sustainability of nature and society. By showing that large-scale, modernized sugarcane plantation cannot guarantee sugar supply security in China, this chapter argues that national food security should not be equated with the production security of each individual crop. Even at the domestic production level, national food security is an entire production system of various crops, including vegetables, fruits, tea, and other non-staple products. In terms of food security, domestic production is only one of the influential factors. There are other factors, such as: food import sources, food storage systems, and the food consumption habit. In addition, social and natural sustainability should be considered when the state pursues its national food security plan. A food production system based on capitalist agricultural production modalities is likely to be ineffective and unsustainable. Food production may be better off relying on the moderate family farming pattern, which returns farming to individual households and rural society. 


\title{
5. Repeasantisation despite Labour Commodification: the Case of Seasonal Migrant Cane Cutters in China
}

\begin{abstract}
Contrary to the prevailing argument that agrarian wage labour is signalling proletarianization of the labour-selling peasants, this paper argues that the engagement in wage-labour might be as well a mechanism of repeasantization. It examines repeasantization from three angles by drawing on the case of cane cutters in South China: Firstly, the paper focuses on the geographical regions from which cane cutters came and shows that there are shifts since 1980s. These shifts relate to the fact that the labour-selling peasants obtain enough income to invest in their own farms and consequently refrain from migration. Secondly, the paper reflects the evolvement of the labour process and compares several types of labour forms regarding to cane cutting, and shows that the cane-cutters are typically relating to the labour market through patron-client relations. Thirdly, the paper considers the social organisation of farms, showing that the specific agrarian calendars of cane farmers and migrant cane cutters strongly complement each other. This allows the cane cutters to engage in both subsistence farming and wage work. However, this interdependence has been interrupted by the land concentration and industrialisation of farming due to the emergence of large cane plantations - with cane cutter peasants being more vulnerable than cane farmers to this transition.
\end{abstract}

Key words: repeasantisation, commodification, wage labour, patron-client relations, China 


\subsection{Introduction}

Commodification of labour in agricultural production is one of the most important topics in the field of agrarian studies. The increases in agricultural wage labour are commonly considered as a signal of proletarianization of the peasantry (also described as depeasantisation) (Bryceson 2000). This argument assumes that peasants lose their land so that they have to engage in wage labour. This proletarianization is perceived and represented as accumulation process that unavoidably moves into one direction. However, today there are more peasants that engage in both farming activities and wage work. This paper, therefore, tries to understand the relation between commodification of labour and the process of re-peasantisation.

Repeasantisation essentially refers to the re-emergence and/or strengthening of peasant agriculture. Van der Ploeg (2013) identifies two dimensions of repeasantisation: first, the creation of new peasant units by certain land institutions or social movements; and, second, the strengthening and/or reinstitution of peasant farming practices, for example through the recent revitalisation of the peasant farming model in western Europe. Huang et al. (2012) on the other hand refer to the 'familization' of farming in China that describes another dimension of repeasantisation, pointing out that 'the family farms had developed into entities that combined powerfully agricultural production with household industry, by the use of cheaper auxiliary household labour - in cotton (spinning and weaving) and silk (silk-worm raising and silk reeling)' (Huang et al. 2012, 22). To understand how repeasantisation could go along with labour commodification, we should retrospect the debates on labour commodification.

The origin of the discussion on the commodification of labour can be traced back to Karl Marx, who, in explaining the expansion of the capitalist farming system in England, distinguished two stages in the historical development of agricultural wage labour. The first is the pre-capitalist stage when 'wage labourers of agriculture were partly peasants, who made use of their leisure time by working on the large estates, and partly an independent, special class of wage labourer, relatively and absolutely few in numbers. The latter were also in practice peasants, farming independently for themselves, in addition to their wages...' (Marx 1976, 877) The second is the capitalist farming stage. Following the usurpation of common lands in England, masses of impoverished rural people were forced to work for wages in the enlarged farms, while these farmers accumulated capital by exploiting wage labour (Marx 1976, 905).

Soviet Union leader Vladimir Lenin generalised Marx's explanation by equating the commodity economy to capitalism, arguing that economic activities in peasant society are subjected to the logic of capitalism. He also argued that the commodification of production leads to peasant differentiation - a polarisation of the rural bourgeoisie and wage workers (Lenin 1982, 130-139). However, Bernstein argued that polarisation of the peasantry is not likely to occur rapidly due to evidence of the long existence of the tradition of combining selfemployment and wage employment. Yet he also pointed out that migration for wage employment was the only option for small-scale farmers who were 'locked into' commodity relations, since they were dependent on the sale of their labour power to meet their personal daily needs (Bernstein 2010, 101-111). 
While the class differentiation perspective offers some strong arguments, the alternative theory on patron-client relations has also been influential in the field of agrarian studies. A number of scholars have shown that peasants engage with patrons for their own security or benefit. Wolf focused on the empowering potential of peasants engaging with their powerful counterparts, contending that 'sharing resources within communal organisations and reliance on ties with powerful patrons were recurrent ways in which peasants strove to reduce risks and to improve their stability' (Wolf 1969, 279). Scott in the 1970s developed this argument into the theory of 'moral economy' in the peasant society, arguing that the theories that rely on the notion of surplus value expropriation are less likely to be an adequate guide when compared to the subsistence test in studying peasant experiences. For peasants, the "safety-first" principle seems to regulate their behaviour and particularly their level of political engagement. For this reason, Scott observed that labour exploitation without rebellion seems to be a common occurrence in agrarian societies (Scott 1977, 1-12). From the economic rationality perspective, Rao pointed out that patron-client relations in the rural labour market benefit both employers and employees, since it reduces transaction costs (Rao 1988). When patron-client relations are strong, labour is referred to as bonded labour since the client is tied in many ways to the patron.

The two fields of investigation discussed above reveal that the issue of whether bonded labour is embedded in or impedes the capitalist system's functioning remains debated. Soiffer and Howe documented changing patron-client relations in a rural town in Brazil at different points in time. They argued that the patron-client complex is not a simple remnant of the past, but rather is a structural feature of a part of the current social formation-rural elite-mass relations commonly exist in the pre-capitalist stage, but finally transit to capitalist modes of production (Soiffer and Howe 1982). Other scholars hold the opposite thesis on the relationship between patron-client relations and capitalism. Brass (2003) and Banaji (2010) both agree that bonded labour is needed and reproduced by capital and is well embedded in capitalism. However, they have diverging views on the issue of free/unfree labour. Brass distinguishes wage labour into free and unfree forms. Bonded labour, in his opinion, is unfree labour, as capital creates this form of labour relations to deproletarianise the peasantry and stifle class consciousness and agency (Brass 2003). Banaji repudiates the distinction between free and unfree labour, insisting that the use of labour is correlated to modes of production in complex ways. According to Banaji, free labour is not a precondition for capital accumulation and there is no dichotomy between free and unfree labour in terms of capitalist relations of exploitation. He argues that the unfree labour is a 'disguised' form of capital accumulation while the 'essential formality of freedom' in Marx’s discourse is its 'deceptive appearance' (Banaji 2010).

Many other scholars in rural studies further explored the relationship between wage labour and capitalism. Some even went beyond the agrarian political economic debate and searched for an altogether new approach to understand the wage labour issue. For example, Lerche argued that patron-client relations go hand in hand with the class-caste struggle. Bonded labour relations hardly hamper collective initiatives among the landless, but the political dominance of landed groups can suppress social resistance among the landless (Lerche 1995). Building on Lerche's argument of replacing the free-unfree dichotomy with a continuum of unfreedoms (Lerche 2011), Guérin points out that bonded labour is the form of cheap labour of a specific regime of 
accumulation characterised by market expansion, labour shortages, governmental programs and the consumption of labourers (Guérin 2013). Using the Global Production Network (GPN) framework which visualises value, power and embeddedness in capitalist production processes, McGrath explains that by constructing a racialised image of migrant workers from 'poor' regions allow buyers to devalue and underpay labourers. In this process, the state plays a central role in maintaining the production network. McGrath concludes that devaluing labour (racism) and state governance are the two main characteristics of producing cane workers in Brazilian ethanol production (McGrath 2013).

In the Chinese context, bonded labour through debt or slave labour scarcely exists, but the inclination of peasants to combine subsistence farming with labour selling is easily observed in China's rural society. The manufacturing industry absorbs a large share of the total peasant labour force in China, but an undetermined number of peasant workers are still paid for agricultural activities. However, scholars diverge on the extent of wage labour employment in China. Huang et al. (2012) calculated ${ }^{68}$ the rate of hired labour as part of the total labour input in Chinese agricultural production, arguing that hired labour comprises between 3 to 8 per cent of total labour input in the agricultural sector. They term the phenomenon of increasing capital input $^{69}$ per unit of land without simultaneously contracting wage labour 'capitalisation without proletarianisation' (Huang et al. 2012). While Huang et al. try to catch the general picture of the whole rural China, Yan and Chen more focus on the uprising capitalist dynamics in the Chinese agriculture - accumulation from above by dragon-head enterprises, accumulation from below with the development of extended family farms, and accumulation from above and below in the rush of building rural cooperatives. They indicated that wage labour employment in the enlarged 'family farms' totals about 28 per cent excluding short-term labour, which is far higher than the estimate of the overall households by Huang et al. Accordingly, they conclude that the Chinese agricultural sector is turning not only to capitalisation, but also to capitalism, with a trend of depeasantisation (Yan and Chen 2015).

This paper engages with the theoretical debate on wage labour in agriculture and its relation to agricultural capitalism, while its focus is not to what extent China's agricultural sector relies on wage labour due to difficulties in obtaining comprehensive information on migrating (seasonal) wage labourers and on employment rates of the wage labour force for large-scale and smallscale farms. 'Hiring in of labour takes a wide variety of forms and extends to a genuinely broad range of producers, even to those with holdings as small as 2 hectares in some areas... [which reflects] the fact that at the lower end of the agricultural scale the cultivation process tends to be labour-intensive' (Astorga Lira and Commander 1989, 778). This paper aims to contribute to this debate by showing that wage labour in agriculture does not necessarily imply depeasantisation. Instead, it might very well be a strategic mechanism in more comprehensive processes of repeasantisation.

\footnotetext{
68 They used the data of 'annual national survey of costs and incomes for different farm products, based on detailed annual sampling of 60,000 farm households in 1,553 counties throughout China', Huang et al. 2012, pp:5.

${ }^{69}$ Capital refers here to financial input in materials, facilities and techniques.
} 
Therefore, this paper holds a historical-geographical perspective to examine the changing cropping schemes and migration decisions of different types of peasants (selling labour or not) in China's cane production sector. In section 2 it discusses two interlinked albeit geographically separated processes in 1990s: the peasant-managed development of farms in southern China that includes the ongoing adjustment of cropping schemes for better income, and the repeasantisation of peasant workers resulting from the labour commodification process through the development of personally-owned farms with earnings obtained from cane cutting following seasonal migration. Section 3 closely examines the labour process and labour forms in the sugarcane production. It argues that wage labour relations can be either capitalist or patronclient (non-capitalist) according to the specific employment modes, while the patron-client employment is more popular in the cane production area. Following this argument, section 4 further explains how the interdependent farming calendars of cane farmers and cane cutters indicates the repeasantisation trend, and how the recent government interventions in agricultural production threatens this trend as well as peasant livelihoods.

\subsection{The history and geography of sugarcane production region and seasonal cane- cutters' migration}

The development of the sugar industry in China and the migration history of sugarcane cutters have shown a complex set of interlocked processes (see the flowchart blow). The paper argues that: First, state policy of moving sugar industry is a key factor, but it crucially depends on peasant livelihood strategies operated in different provinces of China. Second, the shift of sugar industry opens a new labour market in southwest China (even at international level), which does not materialize into a dominance of free wage labour, instead it generates a patron-client labour relation.

Figure 1. The interlocked processes in sugarcane production and labour migration 


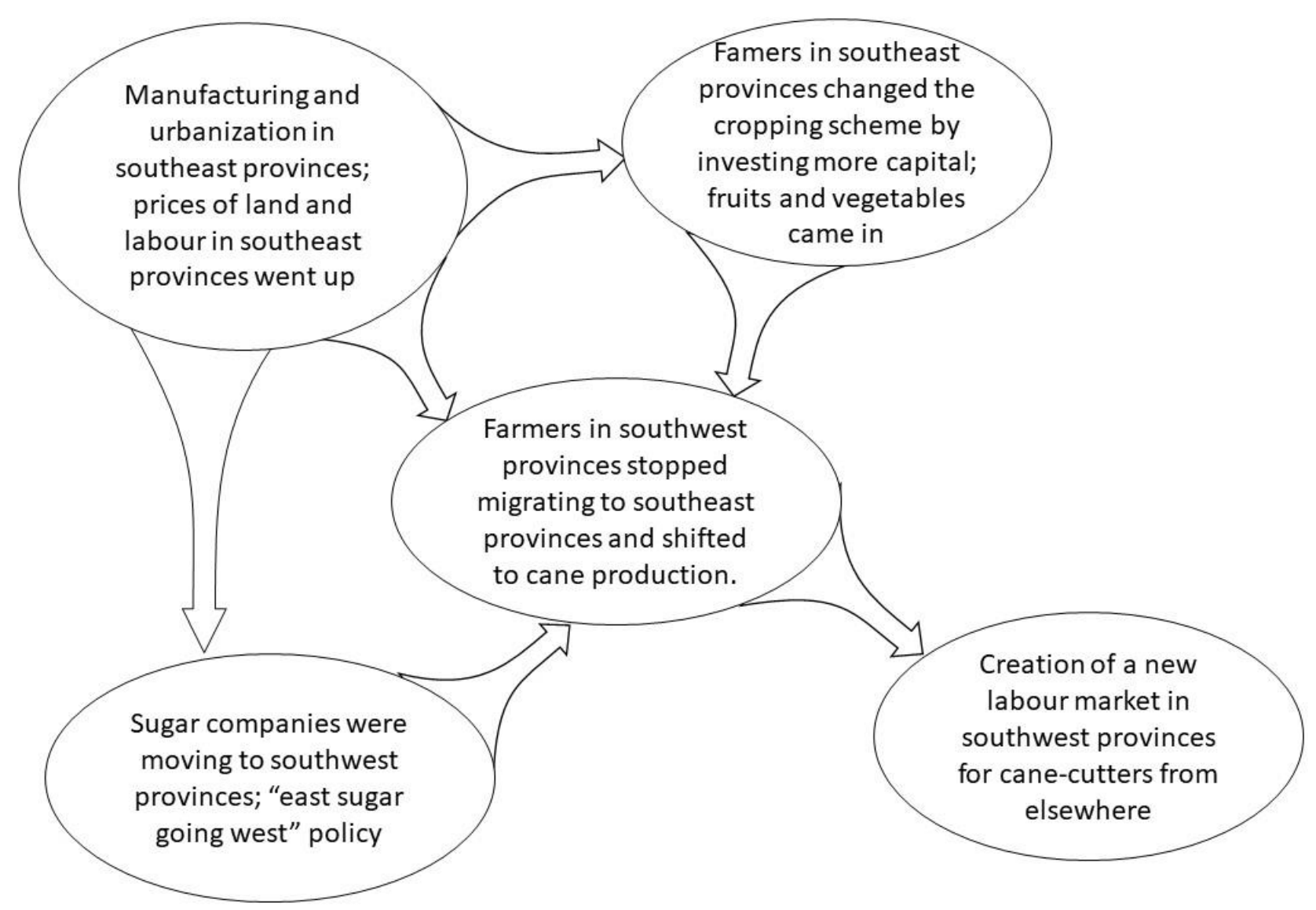

Source: Author's own compilation

The geographical shift of sugarcane production

From the 1980s, the location of China's sugar industry has started to shift. Before 1980, the main sugarcane production zone was in the southeast of China, which includes the provinces Guangdong, Fujian and Hainan (pink zone in Figure 2). However, in the late 1980s, the Chinese government formulated an intervention plan for the sugar industry as part of China's regional economic development strategy. The plan entailed the regional adjustment of the sugarcane production zone, called "east sugar going west" project (Ynsugarnet 2007). At the same time, China's favourable stance toward foreign direct investment led to the boom of the manufacturing industry in the country's coastal provinces. As a result of these developments, the sugar industry gradually shifted to China's southwest region, more specifically to Guangxi ${ }^{70}$ and Yunnan provinces (blue zone in Figure 2) (Luo 2009).

Figure 2. Depiction of the location of China's sugar industry before the 1980s (in pink) and its current location (in blue).

70 Guangxi is short for Guangxi Zhuang Autonomous Region. 


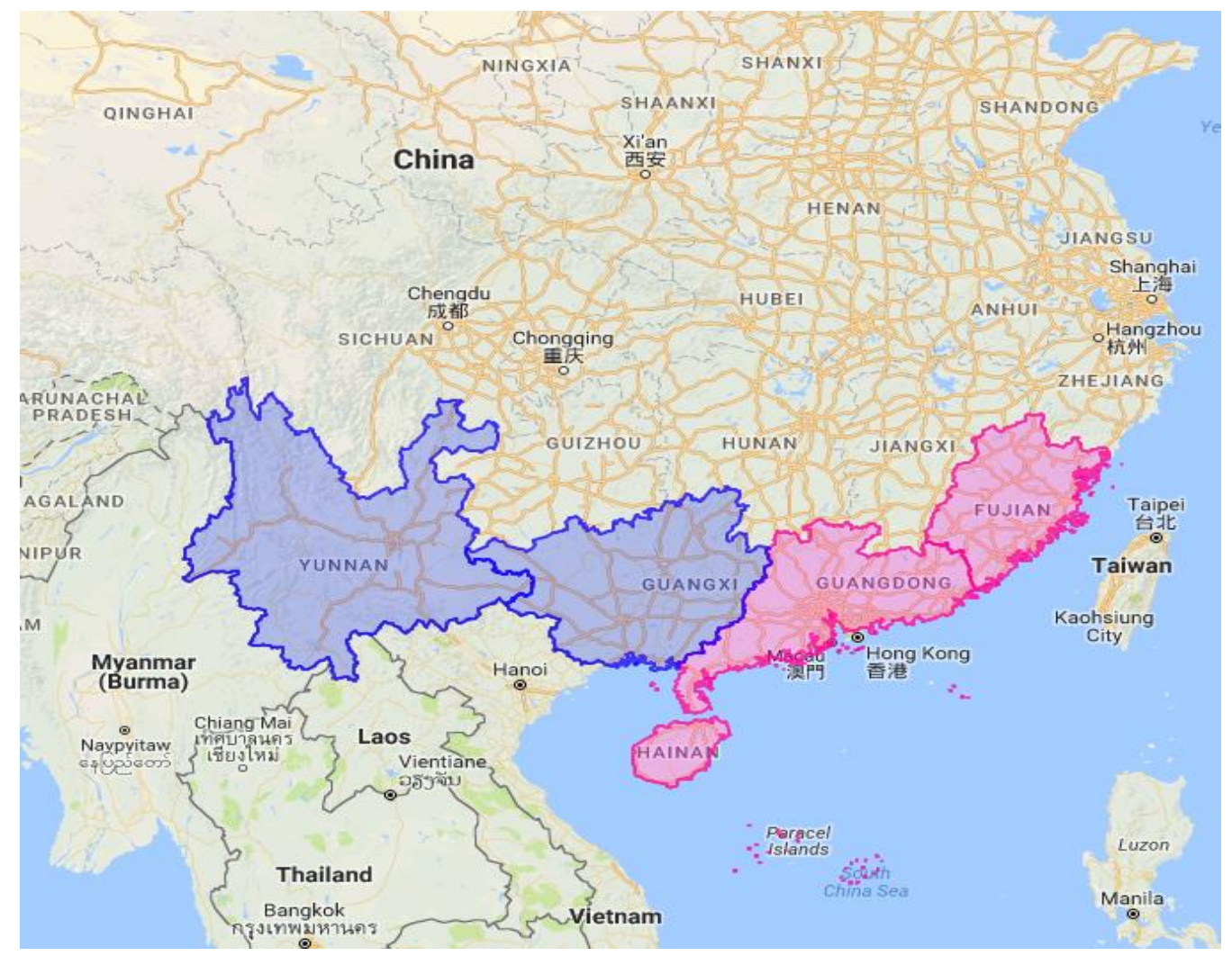

Source: Author's own compilation.

This paper argues that the "east sugar going west" occurred partly through the implementation of China's regional economic development strategy, additionally to the policy, this shift was based more on economic developments related to peasant-managed agricultural development in southeast China. Peasant managed development includes intensification, capitalization of peasant farms, and on the whole a strengthening of peasant farms and an improvement of peasant livelihoods.

The retreat of the sugar industry from the southeast provinces started in the 1990s and is still ongoing. The decrease of farmland acreage in Guangdong, Fujian and Hainan is closely connected to the retreat. At the macro level, the rapid urbanisation in the coastal provinces has meant the absorption of a substantial amount of land and labour into the manufacturing and service industries ${ }^{71}$. Land and labour have become scarce in these provinces, leading to an increase in market prices for these resources. Moreover, this study shows that at the micro level, cane farmers found that while the returns of growing sugarcane could not follow the increases in the market value of their own labour and land, the cost of living and other production factors (like fertilizers, pesticides and the hiring of seasonal labour) also increased. As a result, cane farmers invested in crops with a higher market value, such as fruits, vegetables, tea, tobacco

\footnotetext{
${ }^{71}$ It is critical to mention that urbanisation and peasant-managed development are not contradictory. Peasantmanaged development refers to the situation where the dominant production mode is run by peasant households. This production mode is opposite to feudal/slavery farming, capitalist farming, collective farming, and so on. Although urbanisation can possibly decrease the number of peasant units in rural society, it is not definite. Besides, the emergence of urban farming shows the combination of urbanisation and peasant-managed development.
} 
and herbs. This change in crop preference is reflected in changes in the sowing areas of farm crops in the three provinces during the past two decades (Table 1). The sowing areas for sugarcane drastically decreased and those of fruits and vegetables increased sharply in the period 1990 to 2010. Consequently, sugar companies were forced to withdraw from the three provinces and search for new production areas for sugar.

Table 1. Changes in the sowing areas of fruits, vegetables and sugarcane in Guangdong, Fujian and Hainan provinces between 1990 and 2010 (unit: hectares)

\begin{tabular}{|l|l|l|l|l|l|l|l|l|l|l|l|}
\hline & \multicolumn{9}{|l}{ Guangdong Province } & \multicolumn{3}{l|}{ Fujian Province } & \multicolumn{3}{l|}{ Hainan Province } \\
\cline { 2 - 10 } & 1990 & 2000 & 2010 & 1990 & 2000 & 2010 & 1990 & 2000 & 2010 \\
\cline { 2 - 9 } & 644,730 & 1001,560 & 1081,300 & 298,400 & 559,190 & 536,150 & 36,670 & 141,090 & 174,540 \\
\hline Fruits & & & & & & & & & \\
\hline Vegetables & 517,330 & 1010,100 & 1179,790 & 248,400 & 538,120 & 666,900 & 57,070 & 148,860 & 214,600 \\
\hline Sugarcane & 290,600 & 178,080 & 154,860 & 49,900 & 14,400 & 9,850 & 86,900 & 61,770 & 60,050 \\
\hline
\end{tabular}

Source: National Bureau of Statistics of China. http://data.stats.gov.cn/english/index.htm.

The change reflected in the macro data is the result of the cumulative process of crop choice adjustment by tens of thousands of smallholders due to reasons discussed above. This process that occurred in the three provinces is a type of peasant-managed development. Peasantmanaged development has several characteristics. First, intensified farming activities and upgraded planting systems instead of the expansion of the farming scale allow farmers to retain active engagement in the market through 'entrepreneurship' (Van der Ploeg 2016, 96). Second, investment in new crops, in most cases funded by household savings rather than bank loans, reduces the burden of risk in comparison to that for entrepreneurial farms ${ }^{72}$. Lastly, peasantmanaged development relates to the strengthening of the peasant farming mode. As Bissonnette and Koninck explain, rural labour shortages exert an upward pressure on wages due to continuous urbanisation and industrialisation, which is adverse to large-scale plantations. Meanwhile, capital becomes more accessible and infrastructures are improved in rural areas, allowing smallholders to become more involved in agricultural production (Bissonnette and Koninck 2017, 4).

The dynamics in the new sugarcane production zone

In the 1980s, peasants from Guangxi, Yunnan and Guizhou provinces migrated seasonally to the southeast provinces to work as wage labourers, such as cane cutting. When the sugar industry moved to these provinces in 1990s, local peasants caught up the market opportunity and started to grow sugarcane. Meanwhile, they stopped producing the traditional crops as maize, rice and cassava, and most importantly they ceased seasonal migration. A fast process of reclaiming virgin land and building up a reciprocal labour form followed in the new

72 For a detailed discussion of the difference between farmers with entrepreneurship and entrepreneurial farms in 'China's peasant agriculture and rural society', see Van der Ploeg (2016). 
sugarcane production zone, which quickly brought substantial wealth for the local villagers who were migrant labourers before. With the expansion of sugarcane land in the new sugarcane production zone, reciprocal labour could not satisfy the labour demand, and wage labour was needed again. The interviews about cane cutters in Fusui, Guangxi province shows some characteristics of the seasonal migration.

Interviews with cane farmers revealing cane-cutters' migration history ${ }^{73}$ have shown that three waves of migration of cane workers occurred in Fusui County (red pin in the map) - the largest sugar-producing county in China currently. The first group of cane cutters arrived in Fusui County in the early 1990s from the Dahua, Du'an and Mashan counties (purple pins). In the late 1990s, cane cutters came mainly from the western counties in Guangxi Province such as Tiandeng and Daxin (green pins). In that period, the number of seasonal workers from Dahua, Du'an and Mashan decreased dramatically. Since the mid-2000s, the number of intra-provincial wage labourers dropped off, while the labour demand in the sugarcane production zone increased. This time cane cutters came from northern Vietnam and the marginal regions of Yunnan and Guizhou provinces in China (beige pins).

Figure 3. An overview of three waves of cane cutters in Fusui County, Guangxi, China

73 Since no official records of the migration of cane cutters can be found, the author used group interviews and key informant interviews to understand the migration history of cane cutters in Fusui County. 


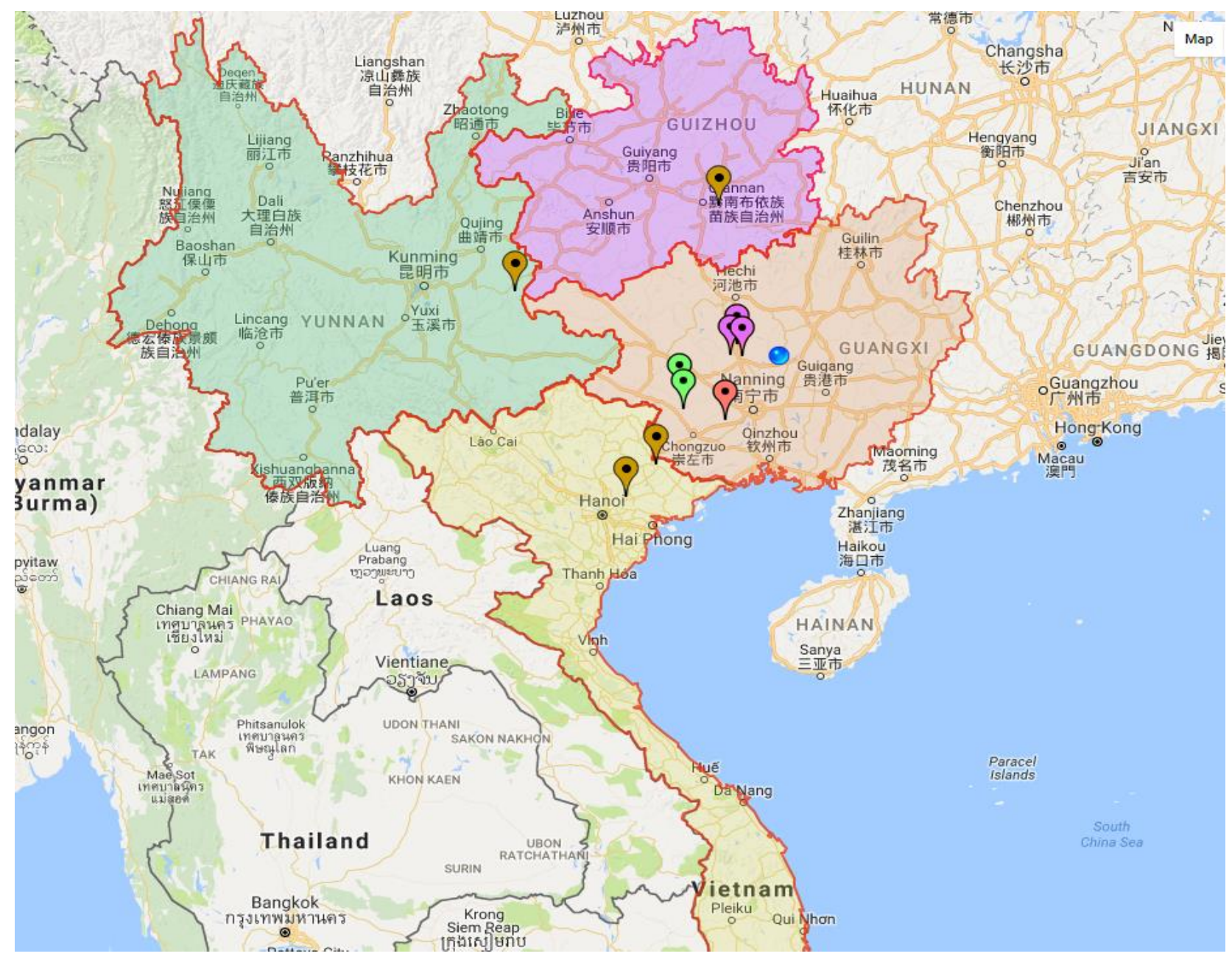

Source: Author's own compilation.

Regarding the link between agricultural commercialisation and the development of the migrant labour market, Lira and Commander in their study of Mexico argued that the growth of the capitalist enterprise consolidated regional and sectoral disparities in Mexico. Through increasing labour flows, enterprises favourably combined their capital and land with those migrants whose main asset is labour. As a result, the cross-region migrant labour market emerged (Lira and Commander 1989, 769). Following this line of argument, this paper focuses on the dynamics of the migration process, that is, it asks why cane workers stopped migrating, while new migrants from other regions took their place. This study sought to unravel this mystery, with Fusui cane farmers explaining that in the early 1990s cane cutters came from the northern neighbour counties and dominated the local labour market because they could offer lower wages than local labourers. After nearly a decade, most of the cane cutters gained savings from the heavy labour work to invest in building new houses or expanding their own farming activities. Meanwhile, they gradually demanded higher wages due to their decreased willingness to do hard physical labour. Peasants from the poor western counties then took over the work by accepting lower wages. After another decade, these peasants also realised substantial improvements in their livelihoods, and accordingly they increased their labour prices as well. As a result, workers from more remote and impoverished areas like northern Vietnam and Yunnan and Guizhou provinces in China took their place. 
The combination of utility-drudgery balance influences peasants' decisions regarding the necessity of migration and self-farming, although the theory was originally to explain the farming decisions of family farms (Chayanov 1966). Migration occurs when poor peasants cannot support their livelihood or maintain their farms through the subsistence farming and have extra labour to sell. Agrarian Marxists tend to argue that migration is a permanent reality among medium-scale and small-scale farmers (Bernstein 2010, 102-112). However, the empirical data presented in this paper show that the agricultural migration process is periodic and that peasants sell their labour temporarily for the sake of accumulating savings to invest in their own farms. This life cycle of rural individuals transiting from wage labourers to simple commodity producers has been demonstrated clearly by Friedmann (1978), who pointed out that because of demographic pressure (more sons in a rural family), wage income is collected for the expanded reproduction of simple commodity farms, that is, to build up a new household farm for the extra son (Friedmann 1978). For the cane cutters, investing in their own farms is one way of doing this, but setting up other non-agricultural business in rural society is another way.

\subsection{The newly emerged labour market and labour relations in Fusui}

This section further examines the newly emerged labour market in the sugarcane production of Fusui County. Three questions are discussed: How did labour become commoditised? What are the forms of wage labour and how great are the differences between them? What are the key factors in promoting the labour hiring process? By answering the three questions, this section seeks to explain the relations between labour commodification and rural production.

\section{Reciprocal labour on the wane}

Sugarcane is not only a land-intensive crop, but also a labour-intensive crop. When sugarcane planting became popular in Fusui County in the late 1980s, the first production problem encountered by the local villages was not related to labour, but to land. Before sugarcane became a popular crop, rice, maize and cassava were the traditional crops grown by the farmers. These crops were subsistence/non-cash crops, and the farmers grew them mainly for their own consumption. Each household retained a balance between the scale of the cultivated land and the food demand of the family. Some of the young rural peasants occasionally migrated for a wage income, for instance working as cane cutters in southeast China. After the sugar industry shifted to their hometown, local farmers rapidly turned to sugarcane production since the market channel was secure and the purchase price was much higher than that of subsistence crops. The strong economic incentive impelled the farmers to reclaim virgin land for sugarcane production. Thus, by the mid-1990s all potential arable land, including hilly or mountainous land, had been completely reclaimed for sugarcane cultivation.

The expansion of sugarcane cultivation brought with it a second problem-labour shortages during the sugarcane harvest season. In early 1990s, seasonal labour shortage was already observable. The labour shortage was the result of various socio-economic factors. The number of labourers declined after the One-Child Policy was implemented in China in 1980. The Nineyear Compulsory Education Law introduced in 1986 made schooling compulsory, so that 
adolescents could not labour on family farms. In addition, the more significant seasonal figure of sugarcane production intensified labour demand in local production. The temporal labour shortage could be solved by the rearrangement of the labour force-from family labour to reciprocal labour. Reciprocal labour took place in the form of mutual-help groups in Fusui County, with each mutual-help group usually comprising between 8 to 10 rural households and each household contributing one high-stamina labourer to the work team. Work team in turns harvests sugarcane for each participating household. Regarding to the disparity of the workload among these farms, workdays ${ }^{74}$ would be paid back by the household that had relatively more sugarcane. More specifically, if a 10-worker team worked one day extra for one household, this household had to serve 9 workdays in total—one workday for each remaining household.

Labour commodification in rural production is not simply a story of rich versus poor famers; instead, it developed into a more complex socio-economic situation. Reciprocal labour is a variation of family labour, considering that external labour assistance is exchanged with selflabour work. Under the reciprocal labour system, cane farmers avoided wage expenses and maximised their farming income. Nevertheless, this favourable labour system has gradually disappeared in recent years. As the utility-drudgery balance theory shows, famers choose less drudgery when their income is sufficient for sustaining their livelihood and reproducing their farms (Van der Ploeg 2013, 38-40). Cane farmers, after years of self-exploitation for wealth accumulation, preferred to outsource heavy physical work.

However, the determinant cause of pervasively hiring labour is the intensification of farming activities by rural households. Since 2000, the sugarcane-watermelon intercropping system has been introduced by cane farmers in Fusui. Rapidly, the majority of peasant households adopted this system, since growing watermelon can be very profitable in some years and no extra land is required since the seeding and harvesting processes do not interfere with sugarcane seeding and harvesting. The introduction of intercropping changed the agrarian calendar and peak period of labour demand. Watermelon has a short growth period: the planting period is from November to March, and the harvest season is from May to June. November to March is also the harvest season of sugarcane, and watermelon can only be planted after the cane is harvested. The overlapping period made reciprocal labour system problematic, because cane farmers cannot grow watermelon in their own field until they finish the cane harvest work for the group. Besides, every year the watermelon market has shown a transition from high prices in the early harvest season to low prices in the late harvest season. Thus, all farmers using this intercropping system intended to grow watermelon as early as possible. Accordingly, hiring labour became the optimal solution.

\section{Patron-client labour and market labour ${ }^{75}$}

Wage labour manifests itself two main forms: patron-client labour and market labour. The patron-client relationship, according to Scott,

\footnotetext{
74 According to the farmers, one workday equates one labourer working one day in the field.

75 Market labour refers to labour mobilized through the free labour market.
} 
may be defined as special case of dyadic (two-person) ties involving a largely instrumental friendship in which an individual of higher socioeconomic status (patron) uses his own influence and resources to provide protection or benefits, or both, for a person of lower status (client) who, for his part, reciprocates by offering general support and assistance, including personal services, to the patron (Scott 1972, 92).

Market labour on the other hand refers to a different employment relationship whereby employers and employees choose each other in the free market. In Fusui County, the two labour forms co-exist during the cane harvesting season, allowing for a comparison of these two labour forms co-occurring in one socio-economic context.

The geographical origin of labourers is the first observable difference between the two forms of labour. Workers from Vietnam and the mountainous area of Yunnan and Guizhou provinces mostly engage in patron-client labour, while labourers in the market are from local regions, for instance some villages inside Fusui County or neighbouring counties. The degree of distance and familiarity to the cane-producing villages affects decisions related to the type of labour engaged in. Workers from Vietnam and the Yunnan and Guizhou provinces are considered "outsiders", so building and maintaining connections is critical for them to secure employment initially and retain employment on the long run. Besides, due to the long distance travelled between work and home, these workers prefer more stable and secure working conditions. In this sense, the patron-client labour form is the optimal choice. On the other hand, native workers are familiar with the local society and building connections is not a priority. In fact, they try to avoid acquaintance relations in order to bargain freely for wages. As a result, the labour market is resorted to as the space where free deals can be made. In addition, unlike a fixed contract period for the whole harvest season in the patron-client relationship, labourers on the market can enter or exit the market at free will. Because of geographical proximity these farmers enter the labour market when they have extra time and return to their own production activities when necessary.

The second difference between the two forms of labour is the process of building labour relations. Market labourers are organised loosely, using bargaining as a tool for securing employment. Labour markets are usually found in rural town squares, and these peasant workers flock to these squares on a daily basis to seek employment. Employers requiring labourers also arrive early in the morning to look for groups of workers, usually consisting of 8 to 10 people. They negotiate the payment on the spot since the labour price in the market constantly changes according to the labour supply-demand situation, the cane quality of the employers, the conditions of the cane field, and so on. ${ }^{76}$ The labour agreement usually lasts one to five days according to the cane quantity of the employer. After completing the work of this employer, peasants return to the labour market to search for other employment.

The forming process of the patron-client relation is more structured. Brokers in many studies about patron-client relations play the role of mediating contact between distant workers and employers. They are responsible for the labour grouping and labour supply to the employers,

\footnotetext{
${ }^{76}$ Cane quality and field conditions can influence the working speed of cane workers, which is related to their payment. The poorer the quality and condition, the higher the price the cane workers ask.
} 
as Breman's study of the cane cutters in India has shown (Breman 1978). In Fusui County, however, the broker system does not really exist: workers from Vietnam, Yunnan and Guizhou form work teams within their own villages and travel in groups to the cane-producing area. Usually one person acts as the representative of each group, communicating with cane farmers about wages, working conditions, lodging, and other logistics. On the patron side, a household with more sugarcane usually prefers to host a work team for the entire harvest season. Apart from its own farm, the host family helps the work team to seek for tasks from other households. The host family charges the borrower households a hosting fee for hosting the workers, usually between 50 and 100 yuan for each borrower household.

The labour price is remarkably different between the two forms of labour. Workers resorting to patron-client relations is much cheaper than the labourers resorting to the market. In the 2015/16 season, the payment for distant workers under patron-client relation was 1 to 1.2 yuan per bundle $^{77}$, while in the labour market local workers charge above 1.5 yuan per bundle. The wage gap is the result of the different working environments. In the patron-client relationship, the host family provides free lodging, coordinates work tasks, and provides a guarantee of employment to labourers. Therefore, the workers get stable, continuous payment with low transaction costs. Conversely, workers in the market either travel to the market spot every day or live in rental houses close to the market. Thus, transport or housing costs are unavoidable. Short work contracts are made with different employers separately, which may lead to unemployment at intervals. Put another way, while labourers arrange work tasks by themselves, they have higher transaction costs. Accordingly, they ask for higher wages.

Patron-client relations in agricultural society are mutually beneficial to labourers and employers. The payment for market labourers is higher due to the lack of familiarity and uncertainty from both sides. While patron-client relations can raise job security and earnings for the clients while enabling patrons to reduce supervision costs and avoid the higher costs of resorting to the open market (Rao 1988).

\section{The social context of patron-client labour relation}

Of the two forms of wage labour, labour based on patron-client relations is dominant in the Fusui sugarcane sector. Dongmen Town, the largest cane-producing town in Fusui County, absorbs 5,000-6,000 cane cutters every cane harvest season, of which only 20 per cent are sourced locally and the remainder originates from northern Vietnam. Cross-border agricultural labour in many studies has been taken as the result of economic disparity between two regions (see Grasmuck 1982). Economic background is certainly one reason for international labour migration, but it is not the complete explanation especially for international rural-to-rural migration. This paper thus explores on the institutional context that supports the cross-border migration of agricultural labour.

Geographical proximity provides the possibility of labour movement, but cultural-historical links are the social basis of seasonal migration. While in Guangxi Province 87.8 per cent of the

\footnotetext{
77 Bundle is the unit that is used in the payment for cane cutters. After cutting cane and cleaning leaves, the workers bundle up cane stalks. A standard bundle weighs around 15 kilograms.
} 
population comprises people of the Zhuang ethnic group, in Vietnam, the Nùng and Tày people, closely ethnically related to China's Zhuang people, reside especially in the northern provinces, with a total population of around 1.9 million $^{78}$. They speak the languages of the Tai family with variations, and they share the same customs. In general, people in this region, whether in northern Vietnam of southern China, share a long history and to present have strong crossborder marital relations. This allows for easier communication between Vietnamese labourers and cane farmers in Guangxi Province in comparison to communication with Chinese workers from other provinces such as Yunnan and Guizhou.

The rise of high-tech communication tools provides the material basis of the patron-client labour migration. Rapid development of information and communication technologies has great influence on agrarian change. Borras points out that the cheap access to international cable channels, internet, text messaging and audio-video conferencing not only has facilitated labour flows, but also has innovated the agrarian movements (Borras 2009). In the Fusui sugarcane sector, mobile telephony plays an important role in maintaining patron-client relationships. The cheap price of mobile phones has increased the number of mobile phone users in rural China as well as in Vietnam. Chinese cane farmers and Vietnamese workers can easily communicate by mobile phone. They discuss the details of their work contracts through mobile phone, including the number of required workers, work period, rates, lodging, transportation, and so forth. After the contract content is agreed and arrangements made, Vietnamese workers travel to the host family in China. Year after year they keep contact through mobile phone, building trust and maintaining their relationships.

Tolerance to the illegal migration by the local government forms the institutional basis of crossborder migration. The entrepreneurship of local governments plays a critical role in the local development in China since the period of fiscal reform in 1980s. Local governments have shown many characteristics of business corporations, leading to a new institutional development called local state corporatism (Oi 1992). Based on Oi's concept, some researchers further explored the specific performance of local state corporatism in different regions. Murphy (2000) explains how returning migrants have become part of local state corporatism and made the natal communities more conductive to business. Zhan (2015) argues that local state corporatism considerably depends on land revenues obtained through the conversion of rural land to industrial land.

Local state corporatism can operate in different forms. In the Guangxi sugarcane sector, the nonfeasance of the local governments is one form of conducting corporatism. Nonfeasance refers to the fact that local governments acquiesce to illegal cross-border labour migration. The Vietnamese cane cutters in Fusui have no legal working permits. Due to the geographical proximity, they come to Guangxi only by crossing a river or a mountain where border checkpoints do not exist. The local government is cognisant of the situation and ignores the illegality of the migration process and subsequent activities. The reason, according to a local officer, is that farmers will stop growing sugarcane if there are no enough cheap labourers, and

\footnotetext{
78 The number was calculated by the author based on data from the webpage titled 'Vietnam's Ethnic Minorities', available from: https://vwam.com/vets/tribes/nothern.html
} 
as a result the local government will lose its revenue source if local sugar companies cannot make profits. This chain of causality pressurises the local government to ignore the law and work in concert with the sugar companies and cane farmers.

The cultural-historical bond, telecommunication development and institutional localism construct the social context of cross-border migration of cane cutters. The process of rural labour migration is never a simple economic phenomenon. A political economy perspective can help to understand the economic incentive of wage labour in rural production, but it cannot show the social institutions that support the international rural-to-rural migration. This paper suggests that an in-depth process analysis of labour migration is essential to understand labour relations and agrarian change.

\subsection{Interdependency between rural communities and the new threat}

\section{Interdependency between rural communities}

The approach of 'new economics of labour migration' (NELM) analyses migration decisions as 'part of family strategies to raise income, obtain funds to invest in new activities, and insure against income and production risk' (Taylor 1999, 64). Proponents of this approach argue that migration influences agricultural production on both the short and long term. More specifically, the reduction of labour may have a negative impact on short-term production while on the long run remittances from migrants can be invested in household resources and other production activities (Taylor 2003). However, NELM focuses on rural families with permanent migrants. The examination of the seasonal migration of cane cutters in this study has shown that temporary migration bears no negative impact on the agricultural production of cane cutters; rather, it results from the interaction of complementary agrarian calendars.

The household plans of engaging in crop planting are critical for understanding labour hiring and labour selling. In Fusui County, typical household planting plans make provision for sugarcane-watermelon intercropping. A typical annual planting calendar of cane can be viewed

in Table 2, which shows that cane farmers are engaged in agricultural activities for most of the year (except for the period August to October). Because two processes occur in parallel in the winter months (November to March), wage labourers are hired in this period to help with the multiple farming activities. The peasants who work as cane cutters have different yearly plans of crop planting, also planting different types of crops, such as paddy rice, lychees, maize and soy. Tables 3 and 4 show the farming schedules of Vietnamese farmers and Chinese farmers from neighbouring counties, since they have their own plots of land back home. As the tables show, the winter period is the slack season of both Vietnamese and Chinese farmers from other counties. Besides, their farming activities are not as intensive as those of cane farmers. Accordingly, these farmers tend to sell their labour during the cane harvesting season. Migration during the slack season has nearly no impact on their own farming activities. Instead, the wage income they generate can help these households to obtain a better cash flow for their daily subsistence, to allow for enlarged consumption, and to invest in agricultural production.

Table 2. The annual harvesting schedule of cane farmers in Fusui County 


\begin{tabular}{|l|l|l|l|l|l|l|l|l|l|l|l|l|}
\hline & Jan. & Feb. & Mar. & Apr. & May & Jun. & Jul. & Aug. & Sep. & Oct. & Nov. & Dec. \\
\hline Sugarcane & & & & & & & & & & & & \\
\hline Watermelon & & & & & & & & & & & & \\
\hline
\end{tabular}

Note: Watermelon seedling transplanting

Watering/weeding/fertilization/pesticide

Sugarcane harvest (cultivating new cane) Weeding/fertilization/pesticide Watermelon harvest

Table 3. The annual planting calendar of Vietnamese farmers in northern Vietnam

\begin{tabular}{|l|l|l|l|l|l|l|l|l|l|l|l|l|}
\hline & Jan. & Feb. & Mar. & Apr. & May & Jun. & Jul. & Aug. & Sep. & Oct. & Nov. & Dec. \\
\hline Paddy & & & & & & & & & & & & \\
\hline Lychee & & & & & & & & & & & & \\
\hline
\end{tabular}

Note: First-season paddy Second-season paddy Fertilization/pesticide Lychee harvest

Table 4. The annual planting calendar of the Chinese farmers from other counties

\begin{tabular}{|l|l|l|l|l|l|l|l|l|l|l|l|l|}
\hline & Jan. & Feb. & Mar. & Apr. & May & Jun. & Jul. & Aug. & Sep. & Oct. & Nov. & Dec. \\
\hline Maize & & & & & & & & & & & & \\
\hline Soy & & & & & & & & & & & & \\
\hline
\end{tabular}

Note: Soy Maize

Many class-perspective scholars have taken labour employment as a signal for the agricultural capitalisation and proletarianisation of labour-selling peasants (see Bernstein 2010, Zhang 2010, Yan and Chen 2015). However, as Worby contests,

we should abandon the wish to see the mere presence of wage-labour as a sufficient sign of agrarian capitalism, just as it is necessary to forego the desire to view collective or co-operative labour forms as a sign of some lost egalitarian ideal (Worby 1995, 24).

Worby realized, from his study on wage labour and class formation in Zimbabwe, that cotton farmers may accrue surpluses of grain and cash by occasionally hiring casual labour, but it is not oriented at accumulation. Instead, the employment relation helps to generate the required amount of cash for the wage workers (Worby 1995). Stated differently, it is mutual help mediated through money in rural societies. A similar principle underlines the relationship between cane farmers and cane cutters in China.

The Chinese cane farmers accumulated their wealth from previous years of working on farms with family labour (or reciprocal labour). When the employment relationship emerged, it 
increases the income of the cane-cutting households. The economic disparity between the two regions is the precondition of the employment relationship, which does not make the employment relationship exploitative. There are several reasons for the regional economic disparity: First, cane and watermelon produced by cane farmers are high-value products while maize and soy grown by the cane-cutting peasants are low-value products. Second, the market prices are strongly influenced by the different economic levels between regions. The north Vietnamese economy is weaker than the southwest Chinese economy. As a result, even lychee, a high-value product, cannot sell high price in the Vietnamese market.

The development of banking system in rural China also plays a critical role in the emergence of wage labour relations. In Fusui County, a "sweet loan" was introduced to cane farmers several years ago - a banking system based on collaboration between the China Agricultural Bank and sugar companies whereby cane farmers are encouraged to get bank loans, with sugar companies deducting the exact loan amount from the earnings of cane farmers after every harvest season. Under this banking system, sugar companies can mitigate the pressure from turnover of capital for production; at the same time, cane farmers also have better cash circulation. This system has enabled cane farmers to employ seasonal workers in the season before they are paid by sugar companies. Therefore, the existence of employment relations in current rural society is far beyond the class differentiation thesis.

The link between cane farmers and cane-cutting peasants reveals the strong internal network within rural societies that confronts the deteriorated external environment. Globally, the expansion of the market has turned farmers into commodity producers, while their daily subsistence has to be purchased by cash. The seasonality of farming determines that farmers can only get paid after each harvest season, and the long periodicity usually causes farmers to experience difficulties related to cash flows before selling their products. This is exactly the problem of Vietnamese farmers since they can only get income once a year after the lychee harvest $^{79}$. Cane farmers fare relatively better, receiving an income twice annually from both sugarcane and watermelon harvests and accumulating savings after many years of selfexploitation and good harvests. Besides, cane farmers are also supported by the banking system, which effectively eliminates pressure on their cash flow. Therefore, a complementary relationship has emerged: lychee farmers need to earn wages by selling labour, and cane farmers want less drudgery and hire labourers. The consumption on leisure from cane farmers then becomes the source of wage income of lychee farmers. With this socio-economic link, Chinese farmers and Vietnamese farmers have built a social network supporting the sustainable farming practices and livelihoods.

The interdependency of rural communities is the engine that synchronises the processes of repeasantisation and labour migration. Thus, maintaining this interdependency and balance in rural society is critical for sustainable agricultural production and livelihoods. However, the recent admittance of industrial-and-commercial capital in agricultural production in China has threatened this socioeconomic network in the countryside.

\footnotetext{
79 The north of Vietnam is hilly, so lychee is the main crop of the Vietnamese farmers. Rice production is limited and mainly for own consumption.
} 
The entrance of large capital into the sugarcane production industry follows a particular policy trajectory. In 2013, the Chinese government encouraged urban industrial-and-commercial capital to invest in agriculture through a shift of investment to the countryside (Yan and Chen 2015). In the sugarcane sector, a specific project aimed at modernising sugarcane production through building large-scale sugarcane plantations with the standards of specialisation, mechanisation and intensification was established in 2013 (Guangxi Government 2015). This project got two types of capital to into the sugarcane sector: capital in the form of substantial governmental subsidies, and urban private capital. However, since small-scale sugarcane farmers were not part of the project vision, they were excluded when the two forms of capital together shifted the system's nature from dependence on small-scale production to a capitalised plantation production mode.

Hence, large sugarcane plantations are the result of industrial capital entering into sugarcane production. In Fusui County, several plantations were already built while new plantations are under construction currently. These plantations try to reach the standards of modernisation required by the government by means of the implementation of intensive monocropping, mechanisation, integral-control irrigation systems, and the use of technology for amongst others the surveillance of plant growth by Unmanned Aerial Vehicles. Extensive capital investment and subsequent modernisation of the farming system was supposed to lower production costs (especially labour costs), raise yields, and generate more profits.

The direct impact of large cane plantations is that it broke the previous social-economic interdependency between the labour-demanding villages and labour-selling villages. As a result, the livelihoods of both cane farmers and cane-cutting peasants have been endangered. New cane plantations meant that the main production means of the cane farmers-land-was occupied by outside companies. This was possible by means of a land (use right) transfer from rural communities to outside investors. While land transfer, whereby cane farmers lease their land to plantation companies at market prices seems voluntary, the strong policy influence and pressure from local government created an enabling environment for this process. Cane farmers came to the realisation that large cane plantations had put them out of work-which led to migration to cities, since only a few farmers could secure non-agricultural jobs locally.

Meanwhile, cane-cutting peasants faced even more severe impacts on their livelihoods. The first consequence of the establishment of large cane plantations was that jobs as seasonal cane cutters and watermelon pickers were no longer available, since cane plantations apply standard monocropping modes of production, whereby watermelon is no longer cultivated. In addition, land transfer contracts stipulate that plantation companies should give preference to local farmers in providing employment, which means the migrant cane-cutting peasants have less chance to get employed. Cane-cutting peasants moreover have little chance of securing other forms of employment to compensate for this loss, particularly because of the absence of additional skills - they can only sell their manpower. While the small group of Chinese cane cutters could find other seasonal work in the agricultural sector or beyond, the large group of 
Vietnamese cane cutters would face significant challenges in securing wage jobs. This transition severely constrains the livelihood choices of the cane-cutting peasants.

The entrance of large capital into the sugarcane production sector has borne negative effects for the local societies. It has shattered the network of rural communities and has destroyed the sustainability of the rural production and livelihoods. More importantly, to date it has not increased cane yields or generated greater profits than small-scale farming methods. The expected yield of 6 tonne/mu did not materialise, instead, it ends with the actual average yield of 4 tonne/mu being even lower than the yield of 4.5 tonne/mu achieved by small-scale sugarcane farmers. While the reasons for the suboptimal production are complex, conflicts between companies and local villagers and the low efficiency of plantation workers ${ }^{80}$ are the most oft-cited reasons for low yields in the new sugarcane plantations.

The strategy of developing large plantations is also unsustainable. First, substantial capital investment is required for the modernisation process, so that plantation companies would be placed in a precarious financial situation following the depletion of their government subsidies. Second, decreases in production costs did not realise due to the rugged landscape constraining the use of machines, thereby sustaining the manual harvesting system. Although the seeding process is mechanised, energy costs are an additional expense in sugarcane production. Therefore, although the project of building large cane plantations is currently a threat to peasant farming, its future of sustainable development is in question. Just as Chen showed in her study, when capital failed in operating large plantations, family farming will take place again (Chen 2016).

\subsection{Conclusion: the endurance of peasantry}

This paper explained five interlocking processes of peasant-managed development and repeasantisation within the trend of labour commodification in rural China. The paper shows that, first, farmers from China's southeast region switched from sugarcane to high-value crops, which led to the relocation of the sugar industry to the southwest China; second, the farmers in China's southwest who were previously seasonal wage workers caught up the market opportunities that the sugar industry relocation offered and turned themselves into cane farmers; and, third, the rises of new waves of migration of sugarcane cutters in Fusui county clearly show how rural-to-rural migration cycles wax and wane. Moreover, the shifts of the sugarcane production region and the geographical origins of cane cutters have shown the economic vitality of peasant-managed development and the process of repeasantisation. Small or medium farmers would invest their earnings generated through migration-related wage work in their own farms or in other kinds of non-agricultural production activities in the villages. Once their own production activities could support their household needs, they would cease migration.

\footnotetext{
80 Farming work is difficult to monitor and measure. When farmers work for themselves, they put more effort into working out the details. The employed workers in plantations lack motivation to do hard physical labour. But in Fusui County, the banana plantations introduced a "contracting-out system" with employees. This system has shown high efficiency and better results in terms of employment relations in plantations.
} 
Through a detailed analysis of labour processes, this paper concludes that labour commodification is not merely an economic process, but also includes historical, cultural and institutional dimensions. The development of telecommunication technology did not promote the form of free labour in the market. Instead, it strengthened patron-client relations. In addition, this paper also explored the production and livelihood link between cane farmers and canecutting peasants. It argued that an internal network among rural communities forms the socialeconomic basis for sustainable rural production and sustainable livelihoods. However, the intervention of external industrial-or-commercial capital into agricultural production can weaken such social-economic bonds and threaten sustainable ways of living in rural societies.

The existence and resurgence of household-based farming have shown the endurance of peasantry as a way of life. The recent "contracting-out system", referring to the management mode where large plantations contract out production work to individual households, further demonstrates the irreplaceability of peasant farming. This system has proven to be more efficient and to produce better outputs. Agrarian scholars of the Marxist tradition argue that labourers in this form is semi-proletarian or even entirely proletarian in character, concluding that family farming is not an alternative to agrarian capitalism (see Bernstein 2006, Zhang 2010, Yan and Chen 2015). This paper argues the opposite: that the capitalist mode of agriculture (usually in the form of large plantations) seldom functions well in terms of efficiency and sustainability in agricultural production as well as livelihood guarantee of rural residents. However, once large capital dominates the means of production or resources, it can only rely on family farming to generate profits. The question is not whether family farming is the alternative to agrarian capitalism, but whether our government and society should allow large capital to extract profits from family farming. Put another way, large capital never produces any value in the contracting-out system, but by controlling rural resources it occupies part of the wealth produced by drudgery and the self-exploitation of family farmers. To summarise, capital investment in rural society can be allowed, but should undergo critical examination when it involves direct farming activities. 


\title{
6. Rural land institutions in China: present and future developments
}

\begin{abstract}
The registration of rural land usufruct rights in China in 2013 has led to the reopening of a debate on the way in which the country's rural land tenure system should be organized. In my research area-Dongmen Town of Fusui County in Guangxi province, the registration of rural land usufruct rights has shown strong influence on different modalities of sugarcane production. This chapter first reviews three approaches related to China's rural land tenure system: the privatization of the land tenure system, its nationalization, and the strengthening of the current Household-contract Responsibility System. The second part then examines the impact of the new registration of rural land usufruct rights on agricultural production and rural society in Dongmen Town. The research shows that the new registration of rural land usufruct rights not only failed to improve the current state of affairs characterized by ownership disputes and distribution conflicts within rural communities, but also created new problems related to large-scale land transfers to capital holders external to rural communities. In the third section, this chapter distinguishes capital concentrations and cooperative models in the sugarcane production in Dongmen Town and discusses each of them. It argues that while the current land system has facilitated capitalist concentrations in agricultural production, the establishment of cooperatives might be an alternative way of scaling up agricultural production in China.
\end{abstract}

Key words: land institution, land tenure, China, privatization, cooperatives 


\subsection{Introduction: the theoretical debate on rural land institutions in China}

Institutions, according to Douglass C. North, are 'the humanly devised constraints that structure political, economic and social interaction. They consist of both informal constraints (sanctions, taboos, customs, traditions, and codes of conduct), and formal rules (constitutions, laws, property rights)' (North 1991: 97). Many institutions, particularly at the macro level, are consciously designed and constructed in response to perceived needs and according to normative deals (Ritzer and Ryan 2010: 321). The conceptualization of institutions differs across academic disciplines. In agrarian studies, land institutions usually refer to the sets of rules that govern land tenure, land use, land circulation and other land-associated activities. In practice, both formal institutions (e.g. land titles) and informal institutions (e.g. customary tenure) have a significant impact on land activities and agricultural production. Since most theories on land institutions are straightforward and formalized, the primary debate related to institutions has focused on the effects of certain land institutions on different socio-economic settings (Deininger and Feder 2001).

The latest round of the confirmation, registration and certification of usufruct rights pertaining to agricultural land (land registration work in short) in China has taken place since 2013. This land registration policy was introduced due to the increasing popularity of land transfer in rural society under the current rural land system - the Household-contract Responsibility System (HRS). The HRS, officially introduced in 1982 and nationally implemented in 1983, signifies the end of collective farming. Under the HRS, rural communities ${ }^{81}$ collectively own land and are in charge of contracting out usufruct rights to individual households within the community. The distribution of land was supposed to be egalitarian under the HRS; that is, land was intended to be distributed to households according to the number of family members in each household. ${ }^{82}$ The usufruct rights that are contracted out to individual households are called 'land contractual rights' by the Chinese government. Land transfer in rural China refers to the transfer of 'land contractual rights', since land ownership cannot be exchanged or traded by the Constitutional Law of China. According to an agricultural minister, 35\% rural land had been leased out by the original rural household contractors by the first quarter of $2017 .{ }^{83}$

Nationwide, land transfer started in the early 2000s and sped up around the middle 2000s, when the central government introduced a series policy documents to promote land transfer. These include 'Measures for the administration of circulation of rural land contracted management rights' issued in 2005, 'Property law of the People's Republic of China' issued in 2007, which ensures legal protection for the contractual rights of rural residents, and

\footnotetext{
81 During the collective farming period, it was production teams that possessed the ownership of rural land in law. Production teams disappeared with the abolishment of collective farming. And the Chinese government has not changed the law on rural land ownership. Therefore, in common sense, rural land ownership belongs to rural committees.

82 The land distribution rule was egalitarian when the HRS was introduced in 1981. However, many rural communities did not regularly organize land redistribution based on demographic changes. Thus, currently land is not equally distributed within rural communities.

83 CCTV news. http://m.news.cctv.com/2017/03/07/ARTImE317VsbqJ8MNqLhLt4g170307.shtml?winzoom=1 [in Chinese] [accessed on $15^{\text {th }}$ Jan. 2018]
} 
'Decision of the Central Committee of the Communist Party of China on several big issues on promoting the reform and development of rural areas' issued in 2008, in which land transfer and the scaling up of farm sizes are emphasized. While the HRS is based on small-scale, noncommercial farming, these policies show a clear preference for land transfer and scaled-up farms that can be operated by specialized big households (专业大户) and other private owners or rural cooperatives. Therefore, Chinese scholars and government officials have different views of the rural land system and agricultural production modalities.

The discussion began with the observed problems of the HRS. According to Feng (2004), the economic problems of the HRS are related to a low income and heavy tax burden for farmers, caused by small-scale, scattered farming practices and a lack of farmers' organizations or unions to negotiate taxes or fees with the local government ${ }^{84}$. He and Liu (2009) pointed out other problems related to the HRS - the decentralization of rural management and the disempowerment of village committees, which create problems for systematic planning of rural development and the organization of community activities. Other problems pointed out by scholars include land fragmentation and low land-use efficiency due to the egalitarian land distribution under the HRS (Prosterman et al. 1996). One of the reasons for rural-urban migration in China is the lack of income from small-scale farming with scattered plots. Meanwhile, massive rural-urban migration has also led to a land abandonment issue (Liu and Ye 2010, Ye 2015). Furthermore, the small land plots stop producers from using modern farming equipment and thus results in a loss of economy of scale (Zhang and Donaldson 2008).

However, the problem discussed most is the lack of tenure security with the current land institutions. Peter Ho argues that land institutional ambiguity ${ }^{85}$ is a deliberate strategy of the central government to allow for the existence of local, informal institutions in land management. Although the ambiguous land system achieved its institutional credibility among Chinese villagers, the institutional ambiguity gives rise to additional problems, such as land conflicts, a lack of stewardship of land, and an increasing number of impoverished and landless peasants (Ho 2005). Tao and Xu (2007) explain that land tenure insecurity emerged due to frequent land reallocation, forced land requisition, and an ongoing rural-urban migration process. Similarly, Ye (2015) indicates that because of land-based development steered by local governments, frequent farmland appropriation activities occur, alongside the resettlement of peasants and the creation of mass landlessness. Meanwhile, the decline in farmland also threatens food security. The frequent reallocation of farmland, Brandt et al. argue, can be beneficial in some respects, but they also noted the inefficiencies caused by the roughly egalitarian way of land distribution (Brandt et al. 2002). Finally, many studies also try to show that the lack of secure and marketable land rights prevents long-term investment in land, productivity improvement, and wealth accumulation among Chinese farmers (Keliang and Prosterman 2007).

\footnotetext{
84 The agricultural taxes and fees were abolished nationally in 2006.

85 Land institutional ambiguity, according to Peter Ho, shows in four areas: '(a) the legal structure of land ownership; (b) the registration of land titles; (c) the organizational reform of the Ministry of Land Resources; and (d) the establishment of a market for rural land lease' (Ho 2005, 12).
} 
Following discussions on the rural land institutional deficiencies, scholars and policy makers turned to explore the possibilities of changing or supplementing the current rural land tenure system in China. Three approaches exist for the studying of the land tenure system. First, the privatization of land ownership is regarded. Second, the nationalization of land property is scrutinized. Lastly, the strengthening of current land tenure security based on the HRS is a key focus. Ideas and proposals diverge widely for each approach.

Scholars supporting privatization, mostly with a neo-classical or neo-institutional economics background, include Chinese scholars such as Hu Xingdou, Yang Xiaokai, Zhou Qiren, Qin Hui, Dang Guoying, Wen Guanzhong, Xu Chengguang, Zhang Wuchang, and some western experts on rural China, for example Scott Rozelle. The main arguments they put forth are that private land property is the solution for current land tenure ambiguity; that property rights can effectively protect farmland from being illegally expropriated by local governments or companies; that privatization can secure land tenure and as a result boost agricultural productivity since farmers can make long-term investments; that private property can increase land value and thus can decrease the wealth gap between rural and urban residents; that rural land property can contribute to the self-governance and democracy of the rural society; that private property is the social basis of civil society; and that the Chinese government will have greater integrity and will be less corrupt with respect to private property ( $\mathrm{Hu} 2008$, Yang 1993, Dang 2009, Li et al. 1998, Rozelle et al. 2002, Liu 2012). Sargeson has explained that the strong influence of international agencies has affected the strong voice for individual land property rights arising in China. As he wrote,

for more than a decade advisors from the World Bank, Asian Development Bank, and Washington-based Rural Development Institute (RDI) had been providing Chinese research institutes, including CIRD, with training on land and natural resource legislation, consultancy partnerships, and research contracts (Sargeson 2004: 642).

The nationalization of rural land ownership, on the other hand, actually suggests a permanent tenancy system. Chinese agricultural economist An Xiji in 1988 already suggested this, arguing that land ownership was not clear after the time of people's communes, because people's communes did not exist anymore. Secure land tenure is essential for either agricultural productivity or rural society. The permanent tenancy system is suitable for the Chinese context, since it is a combination of nationalizing and privatizing measures. Under this system, land ownership belongs to the state, so that individuals have no right to sell or purchase land. However, villagers can own permanent usufruct rights of their portions of land. Land usufruct rights can be exchanged in the market as private property (An 1988). Later, some well-known scholars, including Lu Xueyi and Dong Shuancheng, also came to support this policy suggestion. They argued that with the development of the market economy in China, land usufruct rights can be inherited as property and used as shares for rural cooperative economic organizations (Lu 2004, Dong 2008). Dong even predicted that the permanent tenancy system would be effective for population control in rural China because land reallocation would no longer take place according to demographic change, and rural families would be more concerned about the ratio of the number of children to the acreage of holding land (Dong 2008). 
The third approach that centres on the continuity of the HRS is accompanied by a considerable diversity of views. Scholars focusing on this dimension of the land tenure system are opposed to either the privatization of land property or the state's permanent tenancy system. Wen Tiejun points out that land is not only a 'production resource', but also a 'subsistence resource' for Chinese peasants. Rural families can maintain a standard level of well-being with income from farming and migrant work. Since China retains the dual ruralurban household registration system and does not have a well-established social security system for rural citizens, land functions as a social security mechanism for rural families. As a result, Chinese cities are not surrounded by large slums. However, privatization can disrupt this balance and result in social instabilities (Wen 2008, Wen 2009). Similarly, Zhang and Donaldson (2013) argue that land privatization would exacerbate class inequality and social tension in rural China and further weaken farmers' position in dealing with more powerful actors (Zhang and Donaldson 2013). From a different perspective, He Xuefeng discusses the danger of private land property and the significance of maintaining the HRS, indicating that privatization would further destroy the identity of rural communities and moral rules in rural society (He and Liu 2010). The semi-industrial, semi-agricultural working structure created by the HRS has provided cheap labour for the manufacturing industry in China, making China more resilient to global economic and financial crises (He 2012).

Other studies within this approach emphasize the importance of land tenure security, but focus on other solutions to strengthen tenure security while maintaining the HRS. For instance, Wang Hui and others have proved that land tenure security has a significant effect on the quality of rural land rental markets (Wang et al. 2015). Sound rural land markets encourage the division of land, which can boost agricultural production and manufacturing or service industries. The secure land tenure can only be effective with the coordinated reform of the dual rural-urban household registration system (Wang et al. 2011). Similar arguments can be found in the study by Deininger et al. (2014), who argue that land tenure security is a precondition for shifting labour out of agriculture to bring about structural transformation and the continued economic attractiveness of rural areas. To achieve tenure security, land reallocation has to be stopped and land transfer should be made possible (Deininger et al. 2014).

The Chinese central government was inclined to support the third approach; that is, to secure land tenure under the HRS. This led to its recent land registration policy. Since the HRS separated land ownership and land contractual rights within rural land rights when it was introduced in 1982, the new land registration policy aims to differentiate the right of land leasers (land contractual rights) from the right of land lessors (actual operational rights) that developed with the arising of land transfer. ${ }^{86}$ Thus, the new land registration policy distinguishes 'three rights' of rural land: ownership (所有权), contractual rights (承包权), and

\footnotetext{
${ }^{86}$ Contractual right is basically usufruct rights. Operational right is the right of land leasees to work on the land
} after the land being transferred to them. 
operational rights (经营权). ${ }^{87}$ However, the policy's main goal is to certify the contractual rights of the original land contracting households (Wang and Zhang 2017).

The land registration work is carried out based on currently existing land allocation situations under the HRS. ${ }^{88}$ To be specific, local governments measure the land plots of each rural household (including acreage, longitude, and latitude) and register the information in the governmental land management system. Based on the information, each household then receives a certificate of their land plots. The new land registration policy also extends farmers' contractual right to $2057^{89}$, terminates land reallocation inside rural communities during the contractual period, and officialises land contractual information at the household level. By setting up the new mechanism, the Chinese government expects to secure land tenure and facilitate rural land transfer.

Figure 1. Visualisation of the relationship between the HRS and the latest land registration work

87 Other translations: 承包权 as contracted/contracting right, 经营权 as management right.

88 The land allocation situations among Chinese rural communities are significantly different. Some communities had regularly land reallocation, while some never had.

89 The land contractual right has time limitation under the HRS. The Chinese central government first set 15 years for the contractual right when introducing the HRS (1983-1997). In 1998, it extended 30 years longer (1998-2027). With the recent land registration work, the central government promised another 30 years (20282057). 


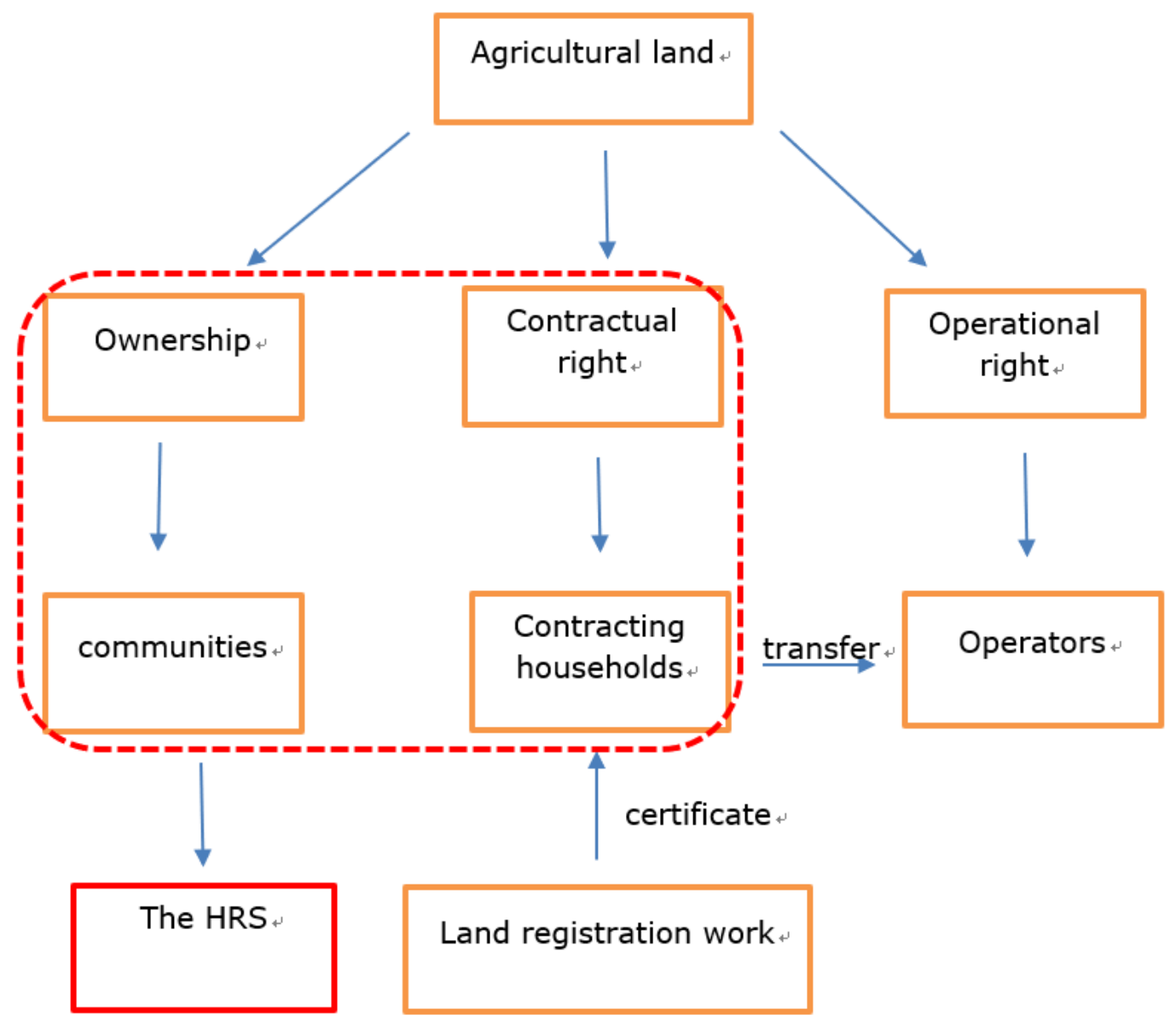

This chapter examines the effects of the latest round of land registration work on increasing land tenure security, the reduction of land conflicts, rural livelihoods, and the promotion of agricultural production. The study was carried out in a rural town in the sugarcane production zone in Guangxi Province. Dongmen Town is under the jurisdiction of Fusui County, located in the southwest of Guangxi Province (see the maps below). Sugar manufacturing is the mainstay industry in Fusui County and therefore it is also the main source of the local fiscal revenue. The total farming land in Dongmen Town is around 200,000 mu, of which 189,000 $\mathrm{mu}^{90}$ is cultivated with sugarcane $(94.5 \%)$. No land reallocation activities have been organized in Dongmen Town after the introduction of the HRS in 1983. There are three specific sugarcane production modalities in Dongmen Town, comprising individual households, corporate farms ${ }^{91}$, and agricultural cooperatives. The new land registration work has different implications for each of the three production modalities.

Figure 2. Maps of the geographic location of Dongmen town in Guangxi Province, China.

\footnotetext{
901 hectare equals about $15 \mathrm{mu}$.

91 Corporate farming (or specialized farming companies) is just one particular type of corporate-led modalities in agricultural production. The other type is the contract farming led by dragon-head enterprise. Due to the contract farming has less implication with the land registration work and land transfer. The chapter thus focuses on the corporate farming
} 


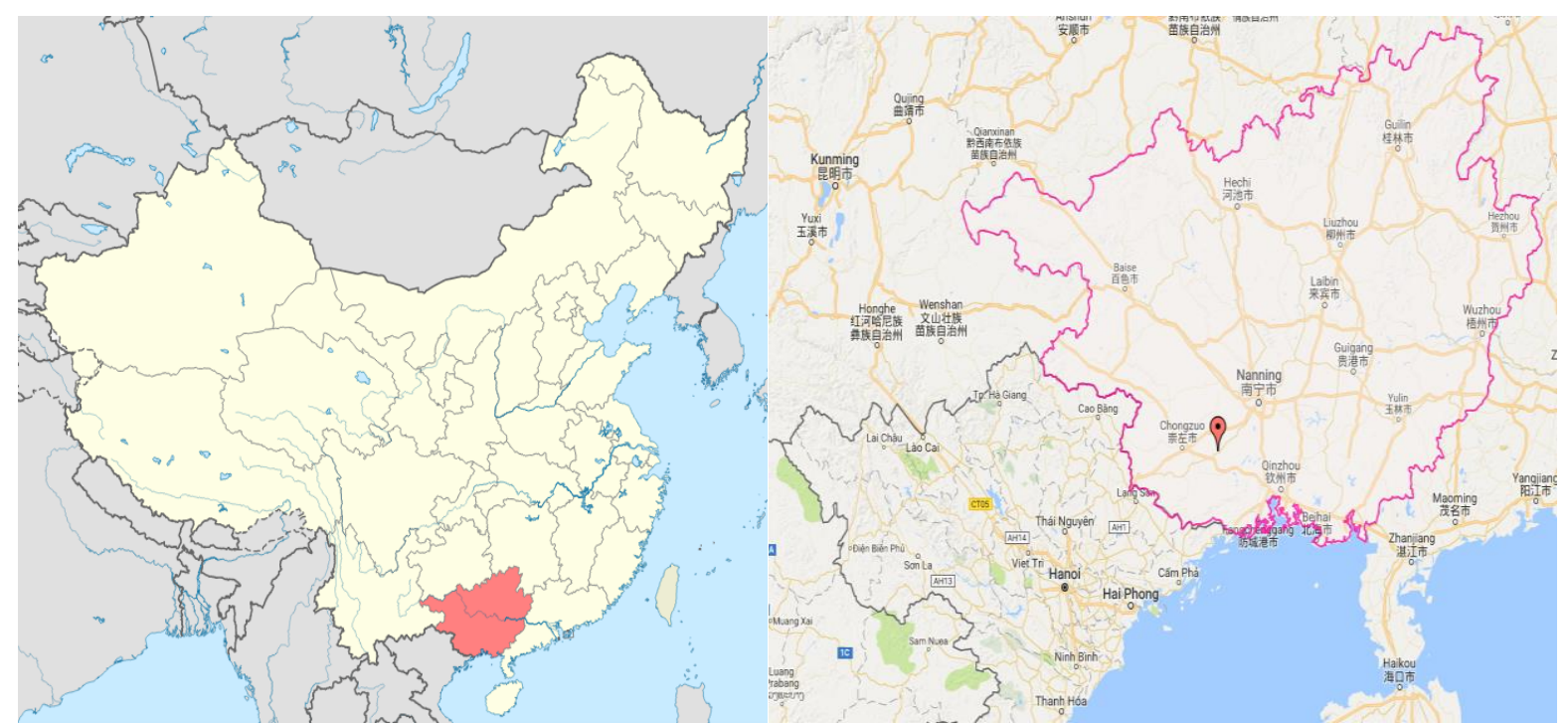

The fieldwork was carried out in Dongmen Town in Guangxi Province in three periods between 2015 and 2017. The data was mainly collected through interviews, participatory observation, and through the study of acquired governmental documents. The following section discusses the implications of land registration work for individual households, largescale land transfers to farming companies, and the trail of rural cooperatives.

\subsection{Continued and increased land conflicts among individual households}

While land possession relations are not always clear in rural China, the fast-developing land rental market drives up land rental prices, stimulating conflict around land benefits within rural communities. Without settling the already exited dispute, the land registration work further exacerbates already-existing disputes.

Under the HRS, land is passed down between generations as an inheritance within rural households. The process of transferring land within families is more of an informal moral convention than a formal legal rule. Interviews with families in Dongmen Town show that elderly parents subdivide their land for their children. ${ }^{92}$ While many specific instances of unclear land subdivision among siblings exist, three situations are the most common. In the first instance, land is not equally divided in terms of quantity, because the quality of different land plots is taken into account in the division process. For instance, one child would get a smaller piece of paddy land while the other would get a bigger piece of dryland. In the second situation, if one child mainly engages in non-agricultural activities (running a grocery store in the village or working as a migrant labourer in a city), he/she would allow the siblings to cultivate more land even though he/she nominally inherits his/her portion of land from the parental family. The third instance refers to the passing down of land to siblings in cases when a child leaves the parental village due to marriage.

92 Dongmen Town did not have land reallocation since the introduction of the HRS. Therefore, the villagers who were born after 1983 have no titled land from their communities. This generation can only get land from the parental generation. 
These unclear land possession relations among siblings in Dongmen Town were not problematic until the development of the land rental market. Before land transfer was marketized in rural society, land was taken as a given resource for family farming instead of a commodity. However, the current situation is vastly different. The land registration work, on the one hand, further enables and inflates the land rental market in rural society; on the other hand, it makes peasants realize the property value of land contractual rights. Land contractual rights can be exchanged in the rental market, and the benefit is substantial. Therefore, conflicts around land possession between sibling families quickly arise in Dongmen Town. These conflicts are so tense that they can act as a barrier to land registration work.

Another complex situation stems from the previous kith-and-kin land transfers that happened before the now-pervasive land commodification process. During the 1990s and early 2000s, some villagers migrated to urban areas. In most cases, these villagers hold land-related contractual rights, but allowed other villagers to cultivate their land for free or in return for a certain amount of grain. These villagers have laboured in cities for many years, and their land has been under other villagers' management for years. Sometimes there is not even a written agreement for the long-time replacement of management. When the land registration work commenced, the non-profitable land transfers faced a crisis. Quarrels or negotiations regarding land possession and land benefits among neighbours and acquaintances also quickly emerged.

While the situations above are related to conflicts over unclear land contractual rights within communities, cross-community land disputes also exist. Unlike the individual conflicts, these disputes are about land ownership. In Fusui County, there are several large state-owned farms. These farms were built during the planned economic period (from the 1950s to 1970s), and the state invested in them due to their important economic function at that time. Thus, when agricultural production in rural communes mainly relied on manpower, these farms were already equipped with modern farming machinery. While these state-owned farms could easily cultivate the land acreage assigned to them, the rural communes did not have the capacity to till all the land they owned because of low labour productivity. Consequently, many rural communes gave permission to the state-owned farms to cultivate the unused land that belonged to the villages. The strong communist ideology during that period led to unclear agreements between villages and state-owned farms. In the 1980s, when the HRS was implemented, and the villages were in the process of distributing land to individual households, state-owned farms turned the "borrowed" land into their own property by registering land ownership deeds at the local government offices.

In Dongmen Town, disputes regarding land ownership are specifically related to a stateowned forest farm. The village committees argue that their previous leaders only allowed the forest agricultural company to use pieces of land, but that they had never ceded ownership. However, the forest farm has not only been operational on these pieces of land for decades, but also possesses land ownership deeds issued by the county government in the 1980s. With the development of the land rental market and the carrying out of land registration work, the dispute regarding the ownership of these land pieces is heating up. For instance, in 2010 two villagers from Palou village were arrested by the local police because 'they occupied the land 
of the state-owned forest farm' according to the police officer. Later, the village committee of Palou tried to take legal action against the farm, but finally capitulated due to pressure from a number of sources, such as lack of money for attorney fee and political sensitivity. In 2015, a violent conflict occurred between Qukan villagers and owners of the forest farm due to a dispute regarding the ownership of over 1,000 mu of farmland.

The second kind of land ownership dispute is related to the land reclaimed by villagers since the introduction of the HRS. The stimulation of the sugar industry in Dongmen Town in the 1980s motivated farmers to grow sugarcane. Sugarcane is a land-intensive crop, but it does not require land of high quality ${ }^{93}$. Thus, farmers were stimulated to reclaim the previous bushland. At present, more than 50\% of rural households have reclaimed land. These land plots are neglected by the current land laws because they emerged after the implementation of the HRS. More specifically, the land was not considered farmland during the collective production period, and accordingly farmers could not attain the contractual rights of these land plots. In fact, the situation is even more complicated. Theoretically, the ownership of the reclaimed land belongs to the villages. However, bushland was generally recognized as an ecological conservation area by the state due to the widespread karst landscape (a landscape that is easy to have water and soil loss) in Guangxi Province. Therefore, although the reclaimed land is part of the collective land, it is uncertain whether the village committees/groups have the right to contract bushland to the villager members for farming.

The land registration work, as mentioned before, only aims to recertify the existing farmers' land contractual rights that are based on the HRS ${ }^{94}$. It definitely is not a recognized breakthrough that reduces land conflicts and helps to clarify unclear land rights in rural areas. The ambiguous land issues, including the ambiguity of land demarcation and unclear ownership, are still problematic. Moreover, the conflicts and disputes will be continuously aggravated by the rising land rental price in the market.

\subsection{Toward corporate farming: the "double constraint" and the economic- environmental crisis}

Farmers' "double constraint" on land contractual rights

The Chinese central government expected that the new land certificates would boost villagers' confidence in land tenure security, so that it could either encourage farmers' long-term investment in land or facilitate their transfer of land operational rights to larger operators. However, the results are not ideal, because land-associated activities are strongly influenced by informal rules, of which local democracy regarding farmers' autonomous rights on land use, land management and land circulation is the most critical.

\footnotetext{
93 Land quality has influence on the yield of sugarcane. But unlike grain crops, sugarcane can grow on poorquality, hilly land.

94 For some areas where land reallocation happened, the registration is based on the most recent land distribution situation.
} 
The Chinese tax-sharing reform in $1994{ }^{95}$ completely altered central national-local fiscal relations. Before the reform, the Chinese fiscal system was highly centralized. All revenues went to the central government and the central government was in charge of national-level budgets (for the civil service, national defence, healthcare, education, etc.) and the expenditures of the local governments. This placed a heavy financial burden on the central government (Wong 2000). With the tax-sharing reform, tax revenues and budgets were separated between the central government and local governments by complex arrangements. However, essentially the profitable revenue sources were collected by the central government. Since then, local governments have been confronted with financial difficulties. This predicament motivated local governments to pursue economic, especially industrial, development in order to gain more revenue, which Oi called 'local state corporatism' (Oi 1992).

In Fusui County, the local government is dependent on the revenue generated by sugar companies, while the sugar companies rely on the local government to stimulate sugarcane production among farmers. During the 2000s, this went well, as the farmers were also driven to invest in sugarcane by the higher sugarcane price as compared to the income that other crops could fetch. Since 2010, however, the domestic sugar industry encountered a crisis due to the falling sugar price resulting from the overproduction of sugar in the global sugar market. The low sugar price led to a low sugarcane price, which dampened the enthusiasm for sugarcane production among farmers. Local farmers gradually turned to more profitable crops, like watermelon, citrus fruits, and eucalyptus. The reduction of the sugarcane supply thus directly impacted the industrial output of sugar companies and the revenues of the local government.

This situation gave rise to what is here called a "double constraint" that farmers in the research area are facing. The first constraint refers to the situation in which farmers do not have the freedom to choose which crops to grow on their own land. This constraint is not a new phenomenon-grain self-sufficiency has been a national policy since the 1950s. During the People's Commune Period, agricultural production was highly centralized, as was the case for other production sectors. Guided by the central government, rural communes did their best to improve grain output. Economic reform in the early 1980s resulted in economic decentralization in China. As a result, the centralized grain production plan was replaced by a localized plan for grain self-sufficiency. This localized plan was called the "governor's grain bag responsibility system", because local governments (especially at the provincial level) were held responsible for their local grain supply-sufficiency (Fang and Beghin 2000). Accordingly, local governments strongly advised farmers to produce grain, sometimes with little consideration of the profitability and regional comparative advantage of grain production (Lin 1992). Since then, local governments have gained the power to influence the farming activities of rural households. 95 Fiscal reform in China commenced in the mid-1980s; the tax-sharing reform in 1994 has the most influence
on the central-local government relations. 
The constraint regarding farmers' crop choice led to a change from the prioritization of grain production to a preference for industry-related crops as a result of the decentralization of the governmental financial system. Since local governments' finances rely on local industry, the administrative influence on crop choice is determined by the type of local industry. For instance, the sugar industry is the sole industry in Dongmen Town. The local government thus encourages farmers to grow sugarcane instead of grain crops. When the sugar market was prosperous, farmers were naturally driven by market profits to invest in sugarcane without needing any administrative guidance. However, some farmers changed to other high-value crops after the sugar market crisis. Thus, to ensure the sustenance of tax revenues from the sugar industry, the local government actively attempts to influence farmers to switch to other crops.

The local government intervenes in the choices of farmers in three ways. First, it disseminates propaganda posters, which can be found everywhere in Dongmen Town. The posters state, for example, that "eucalyptus is poisonous", "eucalyptus destroys our environment", "growing sugarcane is the only sustainable livelihood", and "everyone is responsible for supporting our domestic sugar industry". The second method is ideological education. In this case, the government officers pay visits to farmers who have converted to other crops. These talks are a series of ideological conversations attempting to persuade farmers to return to sugarcane cultivation. The keywords in the conversations include: "Communist Party member", "patriotism", "good citizen", "responsibility towards society", "role model", and "pioneer". Last, local governments place political pressure on farmers, for example by making it difficult for them to get access to governmental services and any kind of resources.

The second constraint of the "double constraint" regards the process of land transfer. Land transfer has becoming attractive in rural society due to ongoing rural-to-urban labour migration, increased land rental prices, and farmers' preference for less drudgery. In Dongmen Town, the demand for land is high. On the one hand, some rural entrepreneurs want to build banana plantations, forage-grass farms, or sisal plantations. On the other hand, the government introduced the "double-high" being reduced. Under the project, the government would subsidize relatively larger sugarcane farms ${ }^{97}$. Nevertheless, even with subsidies, these sugarcane plantations still offer a lower rental price than the other crops' plantations because of the lower profit margin related to growing sugarcane. For instance, banana plantations offer 1,000-1,200 yuan/mu in land rent, while sugarcane plantations only offer 900 yuan/mu. Obviously, farmers prefer to lease their land to be used for other crops' plantations.

Here also, the local government intervenes. With similar intervention methods, the local government recommends that farmers cede their land to the sugarcane plantations. The plantations on which bananas or other crops were grown faced many difficulties due to the lack of support from local governments. For instance, these plantations cannot get permission to grow other crops from village committees, even if the villagers already signed land lease

\footnotetext{
96 "Double-high" refers to a high yield and high sugar content of sugarcane.

97 Farms have to be above $200 \mathrm{mu}$ in size for farmers to get access to subsidies, but regular farms are between 10 and $70 \mathrm{mu}$ in size.
} 
contracts, or plantations have been built, but other important resources, such as water, electricity, transportation (the provision of roads), and natural disaster insurance could not be accessed.

Xianlei Ma and others (2015) distinguished three dimensions of farmland tenure security: legal security, actual security, and perceived security. They argued that legal tenure security in rural China has significantly improved, but farmers still experience substantial insecurity regarding actual and perceived land tenure (Ma et al. 2015). The "double constraint" has shown that even though the latest round of land registration work strengthened land security in rural China, farmers still cannot make a free choice regarding their own land's use and transfer. A well-established land system is essential for increasing tenure security and decreasing land conflicts, but it is not a panacea. Informal institutions related to landassociated activities, such as local democracy, also have strong implications for land management. As Peter Ho suggests, the common ownership of collective property can only be expressed through democratic management by the members of the collective who exercise this form of ownership through democratic procedures (Ho 2005). In addition, this chapter argues, local democracy is critical for agricultural production under any type of land management, no matter whether it relates to collective land management or individual land management.

\section{The economic and environmental crisis after large-scale land transfers}

Unlike the small-scale land transfers within families, large-scale land transfers are mostly related to agricultural companies, called 'corporate farm enterprises' by van der Ploeg and Ye (2016). They name three events that can be currently observed in China, of which one is 'the contractual shift of usufruct rights of the land from peasant producers to newly created, large private farm enterprises' (van der Ploeg and Ye 2016: 107). Although the Chinese government expected to promote land transfer to farming corporations by carrying out land registration work, the current institutions related to land transfer cannot provide a safeguard mechanism to protect farmers' interests and agricultural sustainability.

Local villagers face two main problems after large-scale land transfers. First, they face difficulties in obtaining land rental income from farming companies on time, leading to income uncertainty. The Kaili cane-farming company in Dongmen Town collected 6,800 mu land of around 180 local households. According to the contract, Kaili Company should annually pay land rent (of 900 yuan/mu) to these households. However, the company is continuously in breach of the contract. In 2016, land rent was in arrears by three months, and in 2017, the payment was deferred by 6 months. Protests and conflicts around land rent occurred in these two years.

The payment default stimulated the dispute on land redistribution once the contract between the corporate farm enterprise and villagers ended. Before the land transfer, clear boundaries existed between land plots from different households. After the land concentration, Kaili Company cleared land boundaries and changed the landscape in order to build a consolidated plantation. Although the recent land registration work collected the land information in terms 
of acreage and location from each household ${ }^{98}$, it is much more difficult to redistribute the consolidated land pieces into small plots with the original location (locations are linked to land fertility). The expected contract period between Kaili Company and the local villagers is 15 years, but the contract would be annulled if the company claims bankruptcy. The interviews show that the local villagers keep worrying about the future of land transfer. Their concerns include whether they can reacquire their own land, the duration of the consolidated land distribution process, and the utility of the land after redistribution, as land quality may change due to the industrialization of farming.

The second problem local farmers face after large-scale land transfers is agro-environmental deterioration. In fact, rural land systems always have a significant influence on the status of the agro-environment. When the farming system in China shifted from the People's Commune system to the HRS, environmental degradation occurred swiftly and comprehensively in China because the uncertainty of land ownership resulted in short-term behaviour regarding land use ( $\mathrm{Hu}$ 1997). Dongmen Town had also seen environmental degradation, as the villagers burned forests to reclaim virgin land when the sugar industry was developed. This situation has been under control since the Chinese government made efforts to strengthen farmland tenure security ( $\mathrm{Yu}$ et al. 2003). However, the rapid development of the rural land rental market in recent years made the agro-environment more precarious. Plantations use large amounts of plastic films for mulching and plastic pipes for irrigation, and they do not regularly clear away the plastic waste. Thus, piles of plastic waste cover the farmland all year around.

Although the lack of regulations on environmental care in the large-scale land transfer process is one explanation, the fundamental cause of the environmental crisis after large-scale land transfers is the contradiction between long-term land contractual rights held by rural individuals and the short-term operational rights of corporate farms. To be more specific, external capital-holders invest in corporate farms for the sake of making profits. Long-term environmental quality is not their concern, and they can easily shift locations due to the geographic flexibility feature of agricultural production within a certain region (Tu 2014). In fact, it is less costly and more profitable if the farming business periodically shifts from deteriorated agro-resources to premium agro-resources. Therefore, environmental sustainability is never primarily considered by farming corporations. Moreover, the Chinese government has not introduced any regulations on agro-environmental sustainability for either household farming or corporate farming.

The discussion of the economic and environmental problems following large-scale land transfers has shown that there are still serious institutional defects preventing an effective land rental market that guarantees the interests of villagers (land leasers) and ensures that operators (land lessors) conduct environmentally-friendly farming activities. Instead of merely promoting land transfers and large-scale agricultural production, the Chinese government should either improve land institutions regarding large-scale land transfers or explore feasible

98 The location was measured with longitude and latitude. 
organizational modes of agricultural production that can be made effective under the current rural land system.

\subsection{The trial of agricultural cooperatives: an alternative way under the current land system?}

Chayanov (1991) distinguishes two cooperative models in agricultural production: horizontal cooperatives and vertical cooperatives. According to Chayanov, the horizontal model of agricultural cooperatives, which was suggested by Lenin, is

the concentration of peasant land-holdings into large-scale production units in the form of agricultural collectives of various kinds (in the form of agricultural communes, partnerships and associations for joint cultivation of the land) (Chayanov 1991: 21).

The vertical model of cooperatives suggested by Chayanov is

beginning as a rule with the combination of small-scale producers for the procurement of agricultural means of production, cooperatives very soon turn to the organization of the co-operative marketing of agricultural products which they develop in the form of gigantic alliances combining hundreds of thousands of small-scale producers (Chayanov 1991: 10).

Put simply, vertical cooperatives not only cover the purchasing of production material and the selling of agricultural products, but also involve activities such as processing, transportation, marketing, and warehousing.

Currently, 80-95 percent of the agricultural cooperatives ${ }^{99}$ that can be observed in China are fake cooperatives (Liu 2010). The fundamental difference between the fake cooperatives in China and the real cooperatives that Chayanov explained is their economic structure. Real cooperatives, no matter whether in vertical form or in horizontal form, are economic collectives. In contrast, fake cooperatives in China are basically capitalist concentrations. Fake cooperatives can be further distinguished as either vertical capitalist concentrations or horizontal capitalist concentrations.

Vertical capitalist concentrations take place when cooperatives function as intermediary agents between agri-food companies and farmers. The structure is 'company + cooperative + households', as Yan and Chen argue (Yan and Chen 2013). These cooperatives are usually called producer cooperatives in China. Producer cooperatives emerged soon after the HRS was implemented in the 1980s, and the number of producer cooperatives swiftly increased between 1998 and 2003 (Shen et al. 2005). Producer cooperatives provide agricultural products mostly to wholesale markets, agro-processing firms, and supermarkets (Jia et al. 2012). Some producer cooperatives developed into a more advanced form, which is close to the vertical cooperative model that Chayanov describes. These advanced producer

\footnotetext{
99 In some papers, agricultural cooperatives are also called as 'rural cooperatives', 'farmer cooperatives', 'farmer professional cooperatives', 'farmer economic cooperatives', etc.
} 
cooperatives can bring economic benefits to their members as the result of their function on increasing production and market information accessibilities, especially for small-scale farms (Ito et al. 2012).

Horizontal capitalist concentrations essentially refer to the large plantations that emerge after large-scale land transfers. Private capital-holders invest in land transfer and absorb small land plots from individual households into large plantations. Many of these large plantations are registered as agricultural cooperatives at local government offices. One explanation for the popularity of registering capitalist concentrations as cooperatives in the government system is the substantial governmental subsidies for cooperatives in China. The four diagrams below show the different structures of the four models discussed above. Circles represent individual households; rectangles represent cooperative-like forms (a full line refers to real cooperatives, a dashed line refers to fake cooperatives); and ovals represent companies.

Figure 3. Visualisation of the four cooperative models
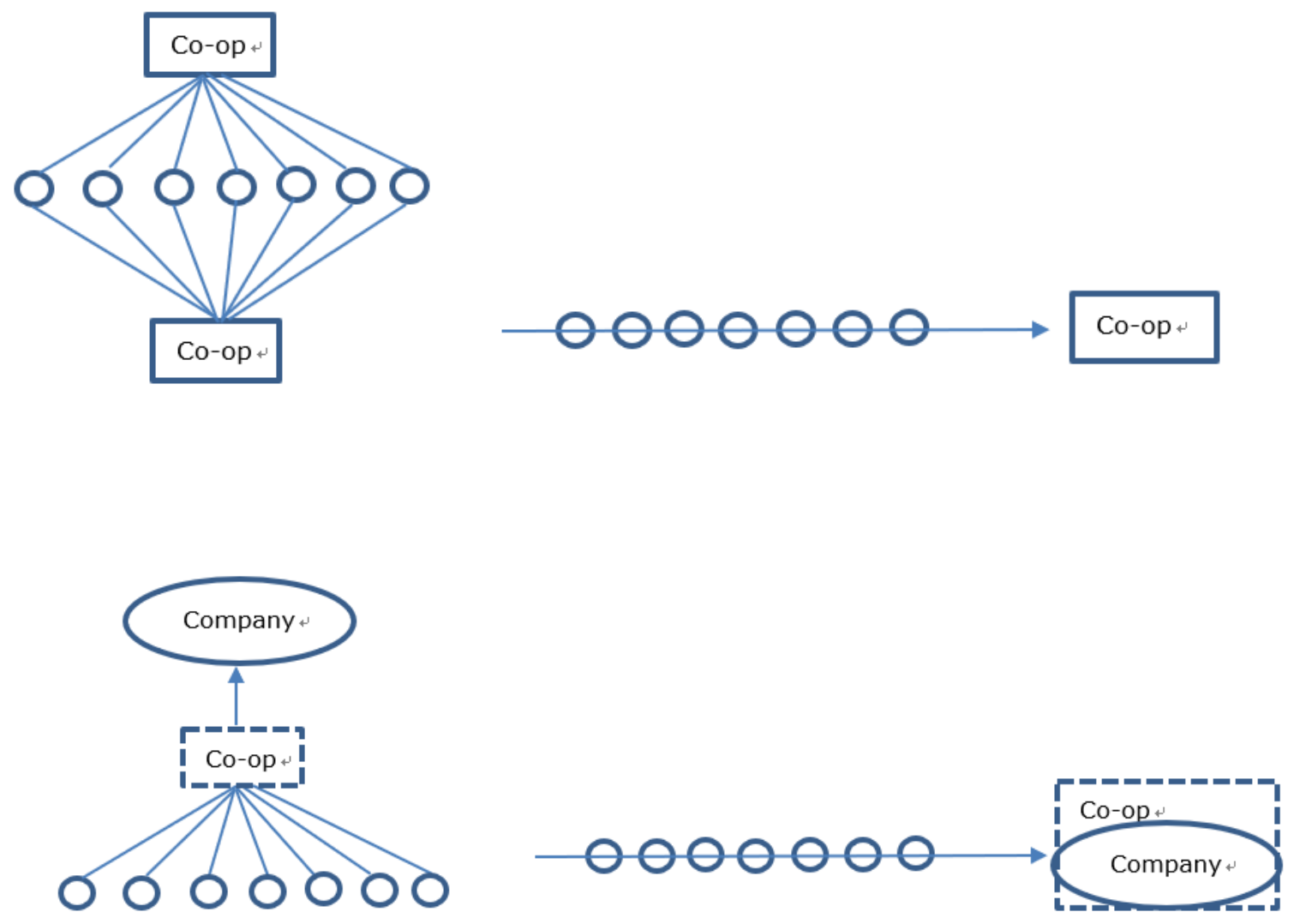

Note: from left above to right below: vertical cooperatives, horizontal cooperatives, vertical capitalist concentrations, horizontal capitalist concentrations)

Since the current land system is pushing for large-scale farming, as the Chinese government intends, the rapid emergence of capitalist concentrations in both vertical and horizontal forms has taken place in China. In Fusui County, the "double-high" project stimulated the increasing 
growth of fake cooperatives. As the chapter has discussed in the sections above, capitalist concentrations in land and agricultural production have negative impacts on rural livelihoods and agro-environmental sustainability. Thus, the question is whether real cooperatives would be the alternative models for scaling up agricultural production under the current land system. The cases of both horizontal cooperatives and vertical cooperatives have been investigated in Fusui County.

In Dongmen Town, horizontal cooperatives have been established in some villages. As part of the local government's land consolidation project ${ }^{100}$, it urged the village committees to mobilize villagers to join cooperatives. Therefore, the initiation of these cooperatives is not completely voluntary, but nevertheless requires the consent of the villagers. These cooperatives are set up horizontally, pooling land as shares and centralizing management structures for sugarcane production. Specifically, a number of villagers hand over their land to the cooperative in order to build large sugarcane plantations which allow mechanical operations. The management committee of each cooperative usually comprises village leaders. Earnings from unified cane production are distributed to participating households according to the size of the ceded land. Land consolidation, levelling and machines are sponsored by the government through its "double-high" project.

As part of the wave of sugarcane production cooperatives springing up across China, one cooperative has upgraded to a vertical setup. Qulu Agricultural Cooperative, located in the neighbouring town of Dongmen Town, is one of the earliest pilot cooperatives in Fusui County. 430 households with in total 3,500 mu of land participate in the cooperative. The management committee of 18 people was constituted by election. As an exemplary model, the local government invested substantially in the cooperative, thereby ensuring its success. As a result, the cooperative expanded its business scope in 2015 from only sugarcane production to provide irrigation services, agricultural machinery services, poultry breeding, transportation, and circulation services by $2017^{101}$. The participating households have land as asset shares, and the villagers can also work for the cooperative business. Qulu Cooperative has been a successful case of the vertical cooperative model, although a large number of governmental subsidies played a crucial role in its success.

To some extent, the current land tenure system does provide the basis for agricultural cooperatives, since land ownership is collective and contractual rights are provided according to private membership. The new land registration system also aids the cooperative establishment by allowing for the measurement of the size of each land plot of individual households. The emphasis on the collective development of agricultural cooperatives alleviates the tension underlying land interest conflicts caused by privatization. Overall,

100 The "double-high" project aims to build 5 million mu sugarcane plantations in Guangxi province that meet the modern agricultural production standards, such as mechanization. Therefore, a project task of a minimum land consolidation acreage has been assigned to each local government in the sugarcane production zone.

101 Qulu cooperative owns two water pumping stations, 21 tractors, 11 cane-reaping machines, and 50 other supporting machines. Reported by the local government: http://www.gx.xinhuanet.com/zt/2017xyji/201707/20/c_1121346494.htm [in Chinese] [accessed on $1^{\text {st }}$ July 2018]. 
agricultural cooperative models have shown its adaptive feature of maintaining the current land system while scaling up agricultural production.

The trial of horizontal and vertical cooperatives in Fusui County also produces negative outcomes, however. First, the establishment of cooperatives is policy-demanding and can place a heavy economic burden on the government. Previous studies have shown that the role of the government is the most important factor in the emergence of farmers' cooperatives in China. The Chinese state had policy support for farmer cooperative since the 1990s, and the 'Law of Farmer Professional Cooperatives' was introduced in 2007. Furthermore, many these cooperatives have subsidies, grants or tax exemptions from the central or local government (Deng et al. 2010, Jia et al. 2012). Second, as Day (2008) pointed out in his study, many of these cooperatives face problems such as top-down administration, a low-entry membership level, inefficient operations, or a lack of democratic management.

Third, horizontal cooperatives may create surplus labour and reduce household incomes. The effects of horizontal cooperatives are differentiated among households. Households with only elderly labourers benefit the most from horizontal cooperatives. However, households with younger labourers are reluctant to join horizontal cooperatives. These households prefer to conduct sugarcane and watermelon intercropping on their land, while large cooperative farms are only specialized in sugarcane monocropping. Furthermore, the failure of collective farming during People's Commune in China stimulated Chinese farmers' doubts of the horizontal cooperative model.

Fourth, it is unclear whether the vertical cooperative model can be sustainable in the Chinese context. Some Chinese scholars have argued that the vertical cooperative model should be institutionalized, comparing Chinese agricultural production conditions-a large population, a farmland shortage-to those of Japan, South Korea, and Taiwan. These scholars have developed a model of vertical cooperative organizations of small farmers (see Wen 2011). However, other researchers question the capacity of Chinese individual households to found cooperative organisations. Since the rural population ratio in Japan, South Korea and Taiwan is less than $10 \%$ of their whole populations while the Chinese rural population ratio is $43 \%{ }^{102}$, Chinese farms are too small in size and weak in economic power (Huang et al. 2012). Furthermore, fragmented, small-scale farming has pushed Chinese rural households to engage in non-agricultural activities. Thus, common interests, social need and internal capital in rural society would be the primary challenges for building vertical cooperatives under the current land system in China.

To summarize, agricultural cooperative models can be an alternative way of scaling up agricultural production, and it fits well with the current land tenure system. However, the weak economic power of Chinese farmers, the large demand for governmental support (both administratively and financially), and the diverse interests among farmers show the difficulties in establishing cooperatives.

102 The rural population ration in China was calculated by the author based on the data from National Bureau of Statistics of China. 


\subsection{Conclusion: reflection on the land policy design in China}

This chapter first reviewed the current policy suggestions on rural land tenure systems among Chinese scholars and then examined the new round of land registration work recently introduced by the Chinese government as a mechanism for securing land tenure, facilitating land transfer, and reducing land conflicts. The results have shown that the new round of land registration work has not only failed to improve the existing situation pertaining to land conflicts and ownership disputes within rural communities, but has also created new problems related to large-scale land transfer to capital holders from outside the rural communities. Finally, the chapter discusses four models of scaling up agricultural production that are currently observable in China: horizontal capitalist concentrations, vertical capitalist concentrations, horizontal cooperatives, and vertical cooperatives. While capitalist concentrations are currently the dominant models, this chapter argues that agricultural cooperatives can be an alternative way of scaling up agricultural production under the current land system in China. However, the lack of an economic basis might be the most formidable challenge in building cooperatives at the grassroots level.

Current land policies in China have been subjected to some misleading ideas regarding agricultural development that causes inefficiency and the further destruction of agricultural production as well as rural development. There is consensus among policy makers, scholars and farmers that the HRS caused land fragmentation and that it is impossible to reconcile new conditions of the developed labour productivity with the limited farming scale in rural China. However, the unsubstantiated idea that large-scale farming is more efficient and productive is pervasive in the design of agricultural policies, evident for example in the direction of industrial and commercial capital flows to the countryside, the facilitation of land transfer, and the subsidizing of large-scale farms. In fact, many studies have shown that the large-scale economy has no advantage over the small-scale economy qua efficiency and other quantitative terms (see Chayanov 1966, 1991, van der Ploeg 2013). As Deininger and Feder (2001) further explained, optimal farm sizes tend not to exceed the scale where family labour is fully occupied in the case where other markets function reasonably well. In cases where the unpaid family labour is not advantageous when it comes to productivity or production costs, the problem is usually that credit and insurance markets, land rental/sales markets, agricultural subsidies, and other markets are distorted by policies (Deininger and Feder 2001: 302-318). In line with these studies, this chapter showed that capitalist concentration in agricultural production, especially the large-scale land transfer from villagers to outside capital-holders, can be destructive to sustainable agricultural production and rural livelihoods.

The chapter also argued that, apart from formal institutions such as national land laws and governmental land regulations, informal institutions are also critical for the land-associated activities. The "double constraint" has shown that local democracy is a key factor in improving land use plans and for the land transfer process. Without a democratic system, local governments could appropriate decision-making power regarding rural land management from rural communities and turn individual land into land resources for 
attracting business. Therefore, the chapter suggested that research on rural land institutions should not be limited to formal institutions such as the land tenure system. Rather, a broad discussion on informal institutions related to land use and management, including the local government system and agricultural production modality, should also take place. 


\section{Conclusions}

\subsection{Introduction}

Food security has always been a critical issue for China. This issue has changed its core composition in the past two decades as the result of new dynamics in domestic agricultural production, structural change in the Chinese diet, and China's accession to the WTO. Meanwhile, the Chinese government has updated its national food security policy, which has greatly impacted on agricultural production and rural society. This dissertation unravels the agrarian change brought about by the most recent food security strategy of the Chinese government by examining the sugar industry and the sugarcane production sector.

Sugar, as a new object in the national food security strategy, has encountered strong state interventions. Recently, sugarcane production in Guangxi province has seen the move-in of state and large capital, the set-up of large enterprises, and the bring-in of new technologies through the "double-high" project. It seems like a top-down, one-sided imposition on sugarcane production, with an inevitable transition to capitalist agricultural production. However, the farmers in Guangxi province have shown different strategies to face the sugar price crisis - the Guangxi farmers have tended to stop growing sugarcane, which has low market value and needs an intensive investment of land and labour. Therefore, the key question is whether the sugarcane production is transitioning to capitalist farming and what role small farmers are playing in the process. This study thus provides a significant contribution to both the theoretical debates and the social-policy domain.

This study employs rural sociological approaches and agrarian political economic perspectives to understand the socio-economic outcomes of the Chinese sugar security strategy. Qualitative data was collected in Dongmen township - one of the most famous sugar-producing townships in Guangxi province - through three periods of fieldwork during 2014 to 2017. The dissertation was organized based on the research line as follows: from the macro-level clarification of the dynamics in the Chinese agro-food sector to the micro-level investigation of the agrarian issues that are related to the sugar security strategy. Chapters 2 to 6 addressed five specific research questions.

Chapter 2 started with an exploration of the main trends in the Chinese agriculture and food sector. The research question was, what is the current systematic situation of Chinese agrofood sector, including the domestic agricultural production, the domestic food consumption and the Chinese and global food trade? This chapter laid the foundation for understanding the following discussion on food policy change, agrarian change, and the interaction between the two changes.

Chapter 3 addressed the question, what are the agrarian changes brought about by governmental intervention projects for the pursuit of self-supplied food security in China (the sugar sector as case study)? It documented the periodisation of the state intervention in the agriculture sector and agrarian changes in China since the 1980s. The chapter then discussed 
the impacts of the recent sugarcane-production intervention project on agricultural production modality, peasant differentiation, and rural livelihood.

Chapter 4 answered the question, how does the agro-food capital renew its accumulation strategies under the national sugar security strategy? This chapter focused on the capital issue in agrarian studies. It presented three accumulation strategies for agro-food capital in the current government intervention project: agro-technification, food politicisation and land speculation.

Chapter 5 focused on the question, does the (cross-border, cross-region) migration of cane cutters signify capitalist labour relations in agriculture production or have another sociostructural significance? This chapter dealt with the labour issue in agrarian studies. The chapter argues that the commodification of labour in agricultural production is more than simply about capitalist labour relations; instead, it could be a mechanism for repeasantisation.

Finally, Chapter 6 explored the question, what are the formal and informal land institutions in China, and how do they influence domestic agricultural production? This chapter examined the land issue in agrarian studies, exploring the implications of the new round of land registration work carried out since 2013. It was chapter argued that land registration and the adjustment of formal titles of land rights tend to be mechanisms to facilitate large-scale land transfer instead of securing land tenure. The chapter also explored the possibilities and challenges of agricultural cooperatives as an alternative model for scaling up agricultural production under the current land tenure system in China.

In this chapter, I will recap the main findings in the five chapters mentioned above, reflect upon the limitations of this study, and present the contributions to the theoretical debates and the policy-making domain. It concludes with a discussion on re-understanding Chinese rural development issues as well as recommendations for future research.

\subsection{The main research findings}

The new dynamics in China's agriculture and food sector

There are two on-going trends in Chinese agricultural production modalities: the first is that the number of scaled-up family farms is growing in the HRS-shaped peasant-farming society, which I call the internal change; and the second is the external relations of peasant farms and the newly emerged agricultural actors, such as cooperatives, farming companies and dragonhead enterprises. There are also two conditions for Chinese agriculture's structural change: one is the rapid increase in land rent and labour price in rural China, which I call the endogenous cause; the other is the structural change in Chinese people's diets - more meat, fish, fruit and vegetables, and less grains - which is the exogeneous driving force. The agricultural structural change can be observed from the crop choice change of Chinese farmers - producing more high-value products, such as livestock/poultry/aquatic products, fruit, vegetables, herbs, tea, etc. As a result, the imports of low-value grain crops have been increasing, which influences China's overseas food strategy. This finding therefore questions 
the popular thesis of China's aggressive profile in global land-grabbing activities due to its domestic food insecurity.

\section{The new predicament of China's self-supplied food security}

Since the 1950s, there have been four state intervention regimes in agricultural production for achieving food security strategy in China-People's Commune period, post-rural reform, fiscal reform and the foreign capital "bring-in" policy, post-WTO period. Peasant farming has played different roles in each regime. The current state perception of "food security" is to secure China's political and economic independence in international food trade relations and to ensure the continuous accumulation of domestic food companies. Therefore, peasant farming is not an ideal mode of production from the perspective of the Chinese government.

This thesis takes the sugar sector as a case study. The new intervention project introduced capital-intensive production modes in sugarcane production in order to guarantee domestic sugar supply and protect the domestic sugar industry. Four capital-intensive production modes emerged in the sugarcane production regions: company plantations, peasant cooperatives, peasant-household joint farming, and entrepreneurial family farms. The top-down intervention squeezes rural society as a whole. However, Chinese peasants have shown strong endurance by making different economic choices under state intervention, which are based on the resources accessible to them, and the concrete market situation of land, labour, food and other elements.

\section{The new strategies of capital accumulation in the agriculture and food sectors}

The sugar-security intervention project brought new opportunities for capital to continue accumulating. However, the three new accumulation strategies are destructive to sustainability in terms of rural livelihoods, agricultural production and food security. Firstly, the application of new technologies shifts more benefits to food companies and more costs to farmers. Secondly, the massive state intervention restructures the sugarcane production and sugar market in China, as well as prospectively impacting global sugar production and markets. Thirdly, the intervention project opens up a new investment market for sugarcane production, which the private urban capital sees as a speculation strategy.

This thesis argues that large-scale, modernized sugarcane plantations cannot guarantee sugar supply security in China. Moreover, the fact that the sugar-security intervention project promotes sugarcane mono-cropping in place of cane-watermelon intercropping means wasted land use. Securing the production of one particular crop cannot achieve the broad goal of national food security. Instead, national food security should be seen as a whole production system of various crops, including non-staple products, at the national level.

\section{Labour Commodification as a mechanism of Repeasantisation}

The seasonal migration of peasants for wage work is part of their livelihood strategy, and is complementary to their farming activities. This type of labour commodification process in 
sugarcane production regions has shown several characteristics: First, the income from wage work is used by the peasants for the development of their own farms (Southwest farmers ceased migration and started growing sugarcane). Second, once the consumption purpose is satisfied, peasants become reluctant to migrate (the three waves of migrant labour in Fusui county). Third, seasonal migration obeys the agrarian calendar of migrant peasants, which shows the strong economic relations between rural societies (the agrarian calendars of cane farmers and cane-cutting peasants). Fourth, rural-to-rural labour migration and the type of employment relations are not only based on economic conditions, but also influenced by historical, cultural and technological aspects (the patron-client relations between cane farmers and cane cutters in Fusui County). These characteristics of rural labour commodification confirm the trend of repeasantisation instead of depeasantisation.

\section{The negative impacts of the new registration policy of rural land usufruct rights}

The new round of land registration policy was introduced by the central government as a mechanism to improve the land tenure security for the sake of facilitating land transfer, since the Chinese government regards large-scale farming as expression of agricultural

modernisation. However, this land policy has had many negative impacts in practice. Among individual rural households, the new land registration work stimulates new conflicts on land benefits between sibling or kith-and-kin families, and it revitalizes previous debates on the unclear land ownership between rural communities. Between rural households and farming companies, the new land registration work did not protect farmers' land tenure security, but instead facilitated the unsustainable large-scale land transfer that has land-grabbing features.

Agricultural cooperatives can be taken as an alternative model for scaling up agricultural production under the current land tenure system. However, the weak economic power of Chinese farmers and the large demand for governmental subsidies proves the difficulties in building vertical cooperatives. The current fast development of horizontal cooperatives in rural China are not efficient in production, or beneficial to rural society.

\subsection{Contribution to scientific debates}

\section{The agrarian change inside China versus China as a land grabber argument}

For a long time, land-grabbing literature took China as one of the leading land grabbers in the global land rush. According to the literature, food insecurity and potential biofuel demand are the main reasons for countries like China to search for direct land and agricultural investment overseas, (Akram-Lodhi 2012, Cotula 2009, Mackenzie 2008, Sommerville et al. 2014, Robertson and Pinstrup-Andersen 2010, McMichael 2013, Zoomers 2010). But quickly some scholars pointed out the unreliability of the data used in this land-grabbing literature. China was over-emphasised or misused in the global land rush by the western media as a way to attract attention (Scoones et al. 2013, Oya 2013). As there is very little reliable data to prove China is a leading land grabber, how should we understand the rising power of the Chinese agribusinesses in the global agricultural and food market? Chapter 1 explained this question by highlighting the domestic agricultural changes. 
Scholars have explored the dynamics in China's agriculture and food sector. Philip Huang argues that the past thirty years in China's agriculture sector have witnessed a 'hidden agricultural revolution', which is represented by the great increase in total agricultural output value instead of the obvious rise of land productivity or labour productivity (Huang 2010). This revolution makes agrarian change in China different from the trajectories in other countries, such as the English enclosure movement or 'green revolution' in India and Latin America. The Chinese agricultural development is 'capitalization without proletarianization', which means Chinese farmers invest more capital in producing high-value products but the employment rate of wage labour is very low. The reason for this phenomenon is that Chinese peasants have started producing more high-value agricultural products, like meat, poultry, fish, milk, eggs, vegetables and fruits. Huang believes that the agricultural structural change is due to the fundamental restructuring of Chinese food consumption habits. This revolution has been led by Chinese peasant farms that invest more capital and labour into farming, rather than by large capitalist farms (Huang et al. 2012).

Based on the previous studies, chapter 2 contributed two main points in understanding the dynamics of China's domestic agricultural production as well as its overseas activities. The first is that the rapid increase in land rent and labour price is the endogenous driver of Chinese agriculture's structural change, complemented with the exogeneous cause of structural change to the Chinese diet. As a result, Chinese farmers began to produce high-value agricultural products. Following the first finding, the second point is related to China's trade in the global agricultural products market. It is shown that while China imports non-grain low-value crops (soy, oil crops, and sugar crops), it exports high-value agricultural products (vegetables, fruit, aquaculture products, herbs, tea, tobacco, etc.). Although the import volumes of soy, oil crops and sugar crops are large, China's deficit in total agricultural trade is not remarkable due to the export of high-value agricultural products. Therefore, the preconception of China being a food-insecure country in the land-grabbing literature lacks solid evidence. China's agricultural 'go out' strategy focuses on getting market channels of demanded crops such as soy, oil crops and sugar crops, instead of direct land investment.

\section{Peasant farming versus capitalist farming}

Belief in the view that Chinese agriculture is moving along a capitalist trajectory has been rising. Zhang and Donaldson examined the labour regimes and class differentiation in China's agricultural production. They distinguished five 'non-peasant forms of agricultural production': commercial farmer, entrepreneurial farmer, contract farmer, semi-proletarian farm workers, and proletarian farm worker. They argue that these labour forms identify multiple pathways of agrarian capitalism and depeasantisation in rural China (Zhang and Donaldson 2010). Correspondingly, Zhang also categorized five classes: the capitalist employer class, the petty-bourgeois class of commercial farmer, two labouring classes of dual-employment households and wage workers, and subsistence peasants. He then argued that the agrarian dynamics drive class differentiation in rural China (Zhang 2015). Yan and Chen studied the accumulation dynamics in Chinese agriculture and argue that the recent development of the new subjects (agribusiness, cooperatives and family farms) in agricultural production shows much capitalist dynamics, and that this process brings the tendency of 
depeasantisation (Yan and Chen 2015). As Bernstein points out, the focus on the agrarian dynamics in China is 'very much in the spirit of Lenin's agrarian studies... which allows for 'exaggeration' (in his term) in order to identify and investigate tendencies and trends that otherwise would remain 'invisible'” (Bernstein 2015: 473).

Chapter 2 and Chapter 3 have different perspectives on the agrarian dynamics in China. While the two chapters agree that the government policies in the past two decades have promoted the emergence of new actors in agricultural production, including dragon-head companies (agribusiness), cooperatives, specialized farming companies and scaled-up family farms, they argue that the new actors have not replaced the dominant model of peasant farming in Chinese agricultural production.

Chapter 2 analysed the different relations between peasant farms and the new actors (see figure 1 in chapter 2) and drew attention to the difference between capitalist production and capitalist relations. While vertical integration of peasant farms by dragon-head companies shows capitalist relations exist in agricultural downstream industry, capitalist mode in agricultural production, as represented by specialized farming companies, is not pervasive in China. The rural cooperatives in China are under different conditions, and it is difficult to discuss at a theoretical level given the substantial number of fake cooperatives. Chapter 3 further distinguishes the conceptual difference between capitalized farming and capitalist farming. While the former refers to capital-intensive agricultural production, the latter indicates capitalist relations, mainly through employment relations, in agricultural production. A detailed analysis of different types of new production modes in Guangxi's sugarcane sector (see table 4 in chapter 3 ) has shown the agricultural intervention policies in China have made Chinese agricultural production more capital-intensive, with a limited degree of capitalist farming.

\section{Repeasantisation versus depeasantisation}

The increase of agricultural wage labour has been argued by many scholars as proof of a trend towards depeasantisation. This argument was established with a wide range of studies, varying from the global-level argument such as that by Araghi (1995) with a historical examination between 1945 and 1990, and Bernstein (2006) on the analysis of 'is there an agrarian question in the $21^{\text {st }}$ century', to local-level studies such as by Singh and Bhogal (2014) about India, by Makki (2012) about Ethiopia, by Paprocki (2013) about Bangladesh, by Córdoba et al. (2018) about Brazil, and by Yan and Chen (2015) about China. However, this argument is being challenged by recent social movements in global agrarian societies.

A number of scholars from various perspectives have argued that peasants in the current capitalist economy are resilient. Van der Ploeg contends the alternative way of farming to capitalist agricultural, which he terms 'new peasantries', in the global south and north (Van der Ploeg 2008). The new peasant rebellions in Latin American countries have shown the global agrarian resistance to the current global food regime which is controlled by international agribusinesses (McMichael 2013). Food sovereignty, agroecology, seed diversity, farmers' rights, fair trade, and other new concepts and social movements also 
facilitate the process of repeasantisation (see Vià 2012, Snipstal 2015, McMichael 2011).

Different from these perspectives, this thesis also contributes to the repeasantisation studies.

While Chapter 2 showed that the "double-high" project did not result in peasant differentiation in sugarcane production area, Chapter 5 argued that repeasantisation also happens along with the labour commodification process. By examining the sugarcane production and the sugarcane cutters in South China, the chapter showed several interlocked processes, including peasant-managed development in Southeast China, migrant workers becoming cane farmers in Southwest China, three migration waves of cane cutters in the logic of utility-drudgery balance, and the interdependent rural societies based on complementary agrarian calendars. Chapter 5 thus drew the conclusions: the agrarian Marxist concept of 'semi-proletarianisation' can be towards repeasantisation instead of exclusively depesantisation, since peasants can invest labour earnings to develop their farms. In this case, market opportunity is a key factor in driving the process.

\section{Land use security versus land privatisation}

In neo-classical or neo-institutional theories, private property rights and competitive markets are the two basic institutions to achieve optimal efficiency in land allocation and land use. The only difference between neo-classical presumption and neo-institutional argument is about the role of the state. The former requires the minimal role of the state in land selling and purchasing process. Only when the market is imperfect, 'the state, as a non-market agency is supposed to intervene to purge these structural and market distorting phenomena' (Atkins 1988: 935). The latter emphasizes the importance of state intervention in the process because of market imperfection, which includes incomplete information, no access to technologies, high transaction costs, etc. For example Lipton criticizes the neo-classic theory, asserting that 'for standard neo-classical economics, rural institutions are "given", "knowledge, organization and technique” remain constant' (Lipton 1993: 641). Neo-institutional scholars argue that institutions should be created to achieve economic efficiency, such as land reforms, green revolution, less urban-biased policy, etc. (Lipton 1977, Griffin 1979). Despite the different opinions on the role of the state, land privatisation with a free land market is considered as the approach to solve many land-related problems, such as land tenure insecurity and use inefficiency.

However, many scholars have shown their concerns about the effects of this approach. Byres argued that the neo-institutional scholars neglected and denied structural change to capitalist economy in developing countries yet this is the crucial means of eradicating massive rural poverty (Byres 2004: 41). According to Byres, large landowners have access to cheaper capital than small farmers in the fragmented capital markets and this allows them to choose more mechanized techniques for more land (Byres 2004: 22). Deininger and Feder also point out that the approach of private property rights with a competitive land market can only be effective with specific preconditions: credit access for small farmers; low transaction costs that means no dualistic distribution of land ownership; regulation on land for agricultural use, an undistorted land sales market; and long-term contracts in the land rental market. But in real 
credit market, the land sales market and land rental market are usually not perfect and may be distorted by government policies (Deininger and Feder 2001: 302-312).

Chapter 6 provided empirical research on the effects of the new round of land registration work for land tenure security. The new land registration work is a pre-step for privatising land contractual rights in China, and is considered as an auxiliary policy to the HRS. The study has shown that the new registration work has not only failed to improve the previous situations characterized by land conflicts and ownership dispute inside rural communities but has also created new problems related to large-scale land transfer to capital holders from outside of rural communities. It argues that apart from formal institutions, informal institutions relating to land tenure, such as local democracy and agricultural production actors, are also critical to land-associated issues.

\section{The methodological implication}

Overall, probably the most important academic contribution of this research is the methodological innovations. The research has shown that the top-down policy interventions cannot produce one-sided results, and farmers have their own strategies which can have bottom-up influences. As a researcher, I examined both the macro-level political-economic structure and the micro-level activities of social actors, and the interaction between the two processes. This research indicates that it is critical to combine actor-oriented studies with political-economic analysis. Even though studies may be generally distinguished as macrolevel or micro-level research, as my future research interests show, researchers must be wary of not neglecting the political-economic structure or the agency of grassroots actors.

\subsection{Policy implications}

Food supply security is a complex issue as it is closely related to agricultural development, rural-urban migration, land systems and other social aspects. So it is important to have a close and accurate assessment of new projects launched by the Chinese government to cope with changes in domestic food production and China-global food trade. Previous studies on China's goal for food self-sufficiency focused on grain, but this dissertation chose the sugar supply security sector, because the Chinese government recently updated the national food security strategy - from grain self-sufficiency only, to the supply security of multiple main agricultural products, including edible oil, sugar and cotton. Thus, this research has strong policy relevance and timeliness.

The "double-high" project seems to be a technological project which brings capital, technologies and new land institutions in sugarcane production, but it also causes a broad range of political-economic changes. The case of the "double-high" sugarcane project presents China's recent agricultural intervention projects of protecting the production of nongrain crops under the national food security strategy. These projects also respond to the 
'Agricultural Supply-side Structural Reform'103 suggested by the Chinese central government, which aims to intervene in the structure of agricultural production in order to achieve supply-and-consumption balance at the national level. The macro-level policy design has a realistic basis, taking sugar, edible oil and cotton as examples. First, the imports of sugar, edible oil and cotton have seen a rapid increase in recent decades, which might suggest China's dependence on the global agricultural products market. Second, the cheap import prices of sugar, edible oil and cotton have severely impacted domestic industries. However, this study has found many problems with this kind of project. The main policy suggestions are listed below.

First, the macro-level food security policy can have a negative impact on rural livelihoods. The 'Agricultural Supply-side Structural Reform' aims to increase the domestic production of sugar crops, oil crops and cotton crops for maintaining a secure level of domestic supply of sugar, edible oil and cotton. However, Chinese peasants become less motivated to grow these crops due to their high demands on land and labour and their low market price. As Philip Huang has already argued, agricultural production in China has grown in a way where Chinese farmers have turned to produce more high-value agricultural products, such as meat, poultry, fish, milk, eggs, vegetables and fruits. And this transition has happened together with capital and labour intensification by small family farms (Huang 2011). Therefore, the macrolevel policy design for food supply security has to some extent conflicted with rural income at the micro level. This research then suggests reflecting on two aspects. The first is the agricultural structural change resulting in the agricultural products supply-and-demand imbalance in China, which, however, should not be recognised as food supply insecurity, as Chapter 2 clearly demonstrated. The second is that if China keeps the current national food security strategy and adjusts the domestic agricultural production structure, it is also important to investigate how to protect the income of agricultural producers at the same time.

The second problem is that the "double-high" project that promotes scaling up agricultural farms can have the opposite effect on the domestic sugar supply security goal. Corresponding to the 'industrial and commercial capital going to countryside', the "double-high" project highly subsidised large-scale sugarcane farms. As a result, private capital holders outside rural communities invested in building up sugarcane plantations. These sugarcane plantation companies are mostly "fund-extracting companies", since these investors built up sugarcane plantations to get substantial project subsidies. The agricultural performance of these sugarcane plantations is not as good as that of small cane producers. As Chapter 4 mentioned, the average yield of the sugarcane plantations is lower than the cane farmers'. Moreover, while most cane farmers have an intercropping system of sugarcane and watermelon, the sugarcane plantations conduct sugarcane monocropping. Another point is the environmentally unfriendly land-use behaviour of these plantations. In the long run, the economic and environmental unsustainability of these corporate plantations can even threaten domestic sugarcane production as well as the sugar supply security goal. Therefore, this study suggests

103 Ministry of Agricultural and Rural Affairs of People's Republic of China. Available from: http://www.moa.gov.cn/govpublic/BGT/201702/t20170206_5468139.htm [in Chinese] [assessed on $4^{\text {th }}$ Sept. 2018] 
that roughly promoting large-scale farms as the method of protecting non-grain crop production is not effective. Including small household producers in the projects to protect non-grain crop production should be considered as an alternative.

Third, new migration phenomena should be taken into consideration by policy-makers. Unlike the most discussed rural-to-urban migration driven by China's industrialisation (this model looks like "demand-pull migration"), this research brings attention to two special types of migration, in Chapters 3 and 5. The first one is "supply-push migration", which refers to the situation when large-scale land transfer happens, and the peasants who do not have land to till cannot get employed locally. This unemployment can turn into what I called the "idleness" phenomenon (see Chapter 3). The problem with "supply-push migration" is that these peasants are passively pushed to migrate, while they do not possess the skills required in industries. This is different from the active rural-to-urban migration in which educated or skilled rural residents seek non-agricultural job opportunities in urban area. This research thus suggests that local governments should be cautious about the negative impacts of large-scale land transfer, and should provide training programmes for unemployed peasants. The second type of migration is cross-border, rural-to-rural migration, which in Guangxi province manifests as Vietnamese peasants working as cane cutters without legal residence permits. The problem with this migration type is that foreign labourers cannot get legal protection due to a lack of legislation. However, this research is aware of the counter-effect of bureaucratic systems, for instance, high fees for legal work permit. Thus, this research suggests that a legal regulation for protecting cross-border labourers while reducing administrative procedures is needed. This can be achieved by setting up a permit-free work zone, for example.

Fourth, clarifying land contractual rights is more urgent and important than certifying land contractual rights. The new round of land registration work is to certify land contractual rights based on the current land allocation situation. However, it neglects the existing problems in land contracting in many rural communities. These problems include land distribution disputes within communities, division conflicts among siblings, unclear kith-and-kin land transfer, reclaimed and untitled land, and land ownership conflicts between rural communities. This research has shown the difficulties in carrying out the new land registration work. Chapter 6 also pointed out that the new land registration work which is promoted by the Chinese government for facilitating land transfer to outside investors has failed to protect land tenure security in rural society. This research shows that the current land system in China has complex institutional relations, such as local democracy and dual ruralurban registration systems. Although there are many aspects to be improved in the current land system, the rural land tenure system is the fundamental issue regarding Chinese agricultural development, rural livelihoods and China's food supply security. This research suggests that resolving the conflicts and disputes about land contractual rights within rural communities is a precondition to continuing the new land registration work.

\subsection{Limitations and future research}

This research has its limitations, which I am fully aware of. The first of these is data limitations. In Chapter 2, the discussion of fast increase in land rent and rural labour prices in 
China lacks accurate statistical data at the national level. This research thus applied some second-hand data from the investigation reports of non-governmental organizations and several provincial governments. Chapter 4 discussed that sugar companies can get substantial profits from by-products while the sugarcane purchasing price is only linked to the sugar market price. The accurate data on costs and benefits of these by-products to the sugar companies cannot be accessed as it is subject to commercial confidentiality. Therefore, the market prices of these by-products are used for analysis. Moreover, the thesis has to use anecdotal data at some points, for instance in Chapter 4, it is stated that Kaili Company's owner shifted business to Southeast Asian countries (Myanmar, Thailand) after cheating on sugarcane subsidies from China. Although the information was provided by a key informant who works at Kaili Company, no official records can be found.

The second limitation is the time span of investigating the project impacts and the dynamics of different agricultural production modes. Although the sugarcane project started in 2013, the official document titled "Development Plan for the Main Sugarcane Producing Area" indicates that the project will last until 2020. Therefore, I assume that new trends in sugarcane production in Guangxi province will emerge after the end of the project subsidies that currently play an important role in the intervention process. Questions include but are not limited to: Will the sugarcane output of Guangxi province increase in 2020? Will more conflicts between peasants and sugarcane plantation companies occur due to rent arrears? Will "demand-pushed migration" cause other social problems, such as unemployment-related issues? Will the Vietnamese cane cutters stop migrating or turn to wage work in industries? Can the sugarcane plantation companies continue to operate? If not (which is the most probable scenario), who is going to take over the plantations: sugar companies or cane farmers? As Chen (2016) has shown in her study about rice production, where capital failed in operating large plantations, family farming took over production again. Therefore, these questions can only be answered after the project ends, meaning this research sometimes does not have solid conclusions about the project's impacts.

Third, there is a limitation of generalising the research results. This research has its unique characteristics: first, it examines the project for sugar supply security. Sugarcane is a landand labour-intensive crop as well as an industrial crop, which distinguishes it from other crops such as grain and tuber crops. Thus, some research findings from the sugar/cane project may not apply to projects for securing the production of other crops. For instance, large-scale industrial production may be effective to produce some crops, such as maize and wheat. Second, the research region is Guangxi province, whose social, economic, cultural and geographical conditions are different from other provinces in China. There are several prominent features that can influence the research findings: no rural land reallocation has happened since the rural reform in 1983, while many rural communities in other provinces had land reallocation in the 1990s; peasants in Fusui County are generally more reluctant to become peasant workers in urban areas compared to rural residents in other provinces; most rural residents in Fusui County are ethnic Zhuang, and they speak the local language that is shared with Northern Vietnamese, as Guangxi province borders Vietnam. Therefore, the research results regarding land conflicts and cheap cross-border labour substitution might be 
regional characteristics. However, these specific characteristics make this research more theme-focused and region-oriented.

Some of the research limitations above have indicated future research direction, such as the questions that remain due to the limited time span of this research. But there are several other topics inspired by this research I would like to further explore. The macro-level research interests are as follows:

First, to explore how factors including Chinese agriculture's structural change, Chinese diet's structural change, demographic trends and urbanisation of the population influence the domestic food supply-consumption balance. The background for generating this research question is that I encountered some contradictory information when conducting this research. For instance, producing vegetables has been popular and profitable for Chinese peasants while the Chinese food consumption data has shown that the consumption of vegetables per capita has decreased in the past decade; the demographic prognoses show that China's population will decrease from $2030^{104}$ while most studies about China's food security issue emphasise the pressure of China's continuous population increase; the argument of overproduction due to agricultural industrialisation in China ${ }^{105}$ seems to go against China's fast increase in agricultural imports.

Following this direction, another macro-level research question is to evaluate the costs of maintaining the current national food security strategy. Put more specifically, to achieve the specific production goals for targeted crops in the "National Planting Structural Adjustment Plan (2016-2020)", such as 1.65 billion mu of grain land or 21 million mu of sugarcane land, how much governmental finance will be invested, and how much will incomes decline among Chinese peasants? The financial costs of the food security strategy should be analysed together with the agricultural import value, related industrial loss (sugar industry as an example), and overseas agricultural investment.

My micro-level research interests are about the agro-ecological cost and gender division of labour in Chinese agricultural production. During the field research in Guangxi province, I observed two outstanding issues in the Guangxi sugarcane production sector. The first one is the ecological cost of the transition to industrialised agricultural production. Since the use of fertilizers, pesticide and agricultural plastic films has shot up, soil fertility decline, sharp biodiversity loss and plastic pollution have become severe problems. The question then is how to adapt environmental governance in maintaining agricultural production sustainability and food supply security (see McMichael 2011). The other issue is about the differentiated impacts of rural income growth and the widespread use of machinery on men and women in rural society. Gender division of labour is a distinct characteristic in Guangxi sugarcane production. The improvement of family income and recent application of machinery in cane production have gradually changed the previous division of labour, which challenges the

\footnotetext{
104 Information is available from: https://www.nidi.nl/shared/content/demos/2015/demos-31-08-debeer.pdf [in Dutch]

${ }_{105}$ Argued by Wen Tiejun. Available from: http://www.farmer.com.cn/xwpd/jisn/201212/t20121217_78575 $\underline{7 . h t m}$ [in Chinese] [accessed on $6^{\text {th }}$ Sept 2018]
} 
gender roles and gender power relations in rural society. Moreover, the gender ratio imbalance in rural China, namely that there are more male residents, makes the social relations of gender more complex. As such, a new understanding of social relations of gender in rural society is appealing. After all, when agricultural investment and rural income show remarkable achievement, non-economic factors such as environmental and gender issues are more critical to sustainable rural development. 


\section{References}

Akram-Lodhi, A.H., 2012. Contextualising land grabbing: contemporary land deals, the global subsistence crisis and the world food system. Canadian Journal of Development Studies/Revue canadienne d'études du développement, 33(2), pp.119-142.

An, X. J., 1988. The discussion on the state permanent-tenancy system. China Rural Economics, (11), pp. 22-25.

Anderson, K., Huang, J., \& Ianchovichina, E., 2004. Will China's WTO accession worsen farm household incomes?. China Economic Review, 15(4), pp.443-456.

Araghi, F.A., 1995. Global Depeasantization, 1945-1990. The Sociological Quarterly, 36(2), pp.337-368.

Astorga Lira, E., \& Commander, S., 1989. Agricultural commercialisation and the growth of a migrant labour market in Mexico. International Labour Review. pp.128, 769.

Atkins, F., 1988. Land reform: A failure of neoclassical theorization?. World Development, 16(8), pp.935-946.

Atkinson, P. and Silverman, D., 1997. Kundera's Immortality: The interview society and the invention of the self. Qualitative Inquiry, 3(3), pp.304-325.

Banaji, J. 2010. Theory and History: Essays on Modes of Production and Exploitation (Vol. 25). Brill.

Ben Y., 2011. COFCO owns 99\% of Tully Sugar. China Daily. Available from: http://www.chinadaily.com.cn/bizchina/2011-07/20/content_12943795.htm [in Chinese] [accessed on $29^{\text {th }}$ August 2016]

Benvenuti, B., 1975. General systems theory and entrepreneurial autonomy in farming: Towards a new feudalism or towards democratic planning?. Sociologia ruralis, 15(1-2), pp.46-64.

Bernstein, H., 2006. Is there an agrarian question in the 21st century?. Canadian Journal of Development Studies/Revue canadienne d'études du développement, 27(4), pp.449-460.

Bernstein, H., 2010. Class dynamics of agrarian change (Vol. 1). Kumarian Press.

Bernstein, H., 2015. Some Reflections on Agrarian Change in China. Journal of Agrarian Change, 15(3), pp.454-477.

Bissonnette, J. F., \& Koninck, R. D. 2017. The return of the plantation? Historical and contemporary trends in the relation between plantations and smallholdings in Southeast Asia. The Journal of Peasant Studies, pp.1-21.

Borras Jr, S. M. 2009. Agrarian change and peasant studies: changes, continuities and challenges-an introduction. The Journal of Peasant Studies, 36(1), pp.5-31. 
Borras Jr, S.M. and Franco, J.C., 2011. Political Dynamics of Land-grabbing in Southeast Asia: Understanding Europe's Role. Amsterdam: Transnational Institute.

Borras Jr, S.M., Franco, J.C., Gómez, S., Kay, C. and Spoor, M., 2012. Land grabbing in Latin America and the Caribbean. The Journal of Peasant Studies, 39(3-4), pp.845-872.

Borras Jr, S.M., Liu, J., Hu, Z., Li, H., Wang, C., Xu, Y., Franco, J.C. and Ye, J., 2018. Land control and crop booms inside China: implications for how we think about the global land rush. Globalizations, 15(1), pp.134-151.

Brandt, L., Huang, J., Li, G. and Rozelle, S., 2002. Land rights in rural China: Facts, fictions and issues. The China Journal, (47), pp.67-97.

Brass, T. 2003. Why unfree labour is not 'so-called': The fictions of Jairus Banaji. Journal of Peasant Studies, 31(1), pp.101-136.

Bräutigam, D. and Zhang, H., 2013. Green dreams: Myth and reality in China's agricultural investment in Africa. Third World Quarterly, 34(9), pp.1676-1696.

Brautigam, D., 2015. Will Africa Feed China?. Oxford: Oxford University Press.

Breman, J. 1978. Seasonal migration and co-operative capitalism: crushing of cane and of labour by sugar factories of Bardoli. Economic and Political Weekly, pp.1317-1360.

Bright Food Group. Homepage: http://www.brightfood.com/cn/about.aspx?Class_ID=11 [in Chinese] [accessed on $15^{\text {th }}$ Jan. 2016]

Bryceson, D.F. 2000. Disappearing peasantries? Rural labour redundancy in the neo-liberal era and beyond. Disappearing peasantries, pp.299-326.

Byres, T.J., 2004. Neo-Classical Neo-Populism 25 Years On: Déjà Vu and Déjà Passé.

Towards a Critique. Journal of Agrarian Change, 4(1-2), pp.17-44.

CCTV news. Available from: http://m.news.cctv.com/2017/03/07/ARTImE317VsbqJ8MNq $\underline{\text { LhLt4g170307.shtml?winzoom }=1}$ [in Chinese] [accessed on $15^{\text {th }}$ Jan. 2018]

Chayanov, A., 1991 (1927). The theory of peasant co-operatives: Introduced by Viktor Danilov. Columbus: Ohio State University Press.

Chayanov, A.V., 1966. The Theory of Peasant Economy, edited by Daniel Thorner, Basile Kerblay, and REF Smith. Homewood, IL: The American Economic Association.

Chayanov, A.V., 1986 [1925]. AV Chayanov on the theory of peasant economy: With a new introduction by Teodor Shanin. Oxford: Manchester University Press.

Chen, Y. Y., 2016. Capital going to countryside: the hidden employment relations and capital accumulation in agriculture. Open Times, (5), pp.92-112.

Chen, X.W., 2016. Return the maize price to the market. China Youth Daily. Available from: http://news.sina.com.cn/c/2016-01-28/doc-ifxnzanm3750780.shtml [in Chinese] [accessed on $26^{\text {th }}$ August 2016] 
Chen, Y. Y., 2013. The rise of Capitalist Family Farms and a reflection on the differentiation of agricultural subjects. Open Times, 4, pp.137-156.

Chen, Y. Y., 2016. A rethink of the rise of capitalized family farms and the differentiation of subjects of agricultural production. Open Times, (4). Available from:

http://www.opentimes.cn/Abstract/1889.html [in Chinese]

China Agricultural Yearbook [Zhongguo yuye tongji nianjian]. 2015. Beijing: China Agriculture Press.

China Agriculture Machinery, 2016. Guangxi push the mechanization of sugarcane production. Available from: http://www.nongjx.com/Product News/Detail/48097.html [In Chinese] [accessed on $27^{\text {th }}$ July 2016]

China Fishery Statistical Yearbook [Zhongguo yuye tongji nianjian]. 1992. Beijing, China Agriculture Press.

China Fishery Statistical Yearbook [Zhongguo yuye tongji nianjian]. 2002. Beijing, China Agriculture Press.

China Fishery Statistical Yearbook [Zhongguo yuye tongji nianjian]. 2012. Beijing, China Agriculture Press.

China Statistical Yearbook [Zhongguo tongji nianjian]. 2015. In National Bureau of Statistics of China. Available from: http://www.stats.gov.cn/english/

Chinese Academy of Social Sciences, 2015.Green Book of Rural Area 2014-2015. Beijing, Chinese Academy of Social Sciences.

CIConsulting, 2016. Adjustment of sugar import tariff came into focus. Available from: http://www.ocn.com.cn/jinrong/201609/bbpof29104133.shtml [accessed on 22 ${ }^{\text {nd }}$ March 2017] [in Chinese]

Clapp, J. and Fuchs, D.A., 2009. Agrifood corporations, global governance and sustainability. In Clapp, J. and Fuchs, D. A. (ed.) Corporate power in global agrifood governance, MIT Press, pp.1-24.

Coelli, T.J. and Rao, D.P., 2005. Total factor productivity growth in agriculture: a Malmquist index analysis of 93 countries, 1980-2000. Agricultural Economics, 32, pp.115-134.

COFCO. Homepage: http://www.cofco.com/cn/index.html [in Chinese] [accessed on $3^{\text {rd }}$ Jan. 2016]

Córdoba, D., Selfa, T., Abrams, J.B. and Sombra, D., 2018. Family farming, agribusiness and the state: Building consent around oil palm expansion in post-neoliberal Brazil. Journal of Rural Studies, 57, pp.147-156.

Cotula, L., 2009. Land grab or development opportunity?: agricultural investment and international land deals in Africa. Iied. 
Cotula, L., Vermeulen, S., Leonard, R., Keeley, J., 2009. Land grab or development opportunity?: agricultural investment and international land deals in Africa. London/Rome: IIED/FAO/IFAD.

Dang, G. Y., 2009. Why is it important to emphasize clear property right During land institutional reform? China Times. Available from: http://www.chinatimes.cc/article/618 2.html [in Chinese] [accessed on 30 ${ }^{\text {th }}$ Jan. 2018]

Day, A., 2008. The end of the peasant? New rural reconstruction in China. Boundary 2, 35(2), pp.49-73.

Deininger, K. and Feder, G., 2001. Land institutions and land markets. Handbook of agricultural economics, 1, pp.287-331.

Deininger, K., Jin, S., Xia, F. and Huang, J., 2014. Moving off the farm: land institutions to facilitate structural transformation and agricultural productivity growth in China. World Development, 59, pp.505-520.

Delgado, C. L., 2003. Rising consumption of meat and milk in developing countries has created a new food revolution. The Journal of Nutrition, 133(11), pp. 3907S-3910S.

Deng, H., Huang, J., Xu, Z. and Rozelle, S., 2010. Policy support and emerging farmer professional cooperatives in rural China. China Economic Review, 21(4), pp.495-507.

Dominique, P. 2015. China should control sugar imports, says Bright executive. Reuters. Available from: http://www.reuters.com/article/china-parliament-sugaridUSL4N0WC1UB20150310 [accessed on $12^{\text {th }}$ April 2017]

Dong, S. C., 2008. The optimization path of reformation in rural land of China. Social Science Academic Press.

Du, S., Lu, B., Zhai, F., Popkin, B. M., 2002. A new stage of the nutrition transition in China. Public Health Nutrition, 5(1a), pp.169-174.

Duan, W.X., 2016. The current situation and strategies of the sugar industry in Guangxi province. Sugar Crops of China, 38 (1), pp.65-72.

Duggan, N. and Naarajärvi, T., 2015. China in global food security governance. Journal of Contemporary China, 24(95), pp.943-960.

Fang, C. and Beghin, J.C., 2000. Food self-sufficiency, comparative advantage, and agricultural trade: a policy analysis matrix for Chinese agriculture.

Forrest Zhang, Q., \& Donaldson, J. A. 2010. From peasants to farmers: Peasant differentiation, labor regimes, and land-rights institutions in China's agrarian transition. Politics \& Society, 38(4), pp.458-489.

Freeman, D., Holslag, J. and Weil, S., 2008. China's foreign farming policy: can land provide security. BICCS Asia paper, 3(9). 
Friedmann, H., \& McMichael, P., 1989. Agriculture and the state system: The rise and decline of national agricultures: 1870 to the present. Sociologia ruralis,29(2), pp.93-117.

Friedmann, H., 1978. Simple commodity production and wage labour in the American plains. The Journal of Peasant Studies, 6(1), pp.71-100.

Friedmann, H., 1982. The political economy of food: The rise and fall of the postwar international food order. American Journal of Sociology, pp.S248-S286.

Frouws, J., 1997. The changing parameters of social regulation and governance in agriculture. In Images and realities of rural life. Wageningen perspectives on rural transformations (pp. 77-88). Van Gorcum.

GAAS (Guangxi Academy of Agricultural Sciences), 2012. Available from: http://www.gxaas.net/ganzhe/Default.aspx [in Chinese] [accessed on $5^{\text {th }}$ March 2017]

Ghose, B. 2014. Food security and food self-sufficiency in China: from past to 2050. Food and Energy Security, 3(2), pp.86-95.

Given, L. M. (ed.), 2008. The Sage encyclopedia of qualitative research methods. Sage Publications.

Gobo, G. 2011. Ethnography. In Silverman, D. (ed.) Qualitative Research (3rd version), pp.15-34.

Goodman, D. and Sorj, B.W., 1987. From Farming to Biotechnology: A Theory of AgroIndustrial Development. Oxford: Oxford University Press.

Grasmuck, S. 1982. Migration within the periphery: Haitian labor in the Dominican sugar and coffee industries. International Migration Review, pp.365-377.

Gregory, D., Johnston, R., Pratt, G., Watts, M. and Whatmore, S. eds., 2011. The dictionary of human geography. John Wiley \& Sons.

Guangxi Government, 1981. Notice on improving grain-sugarcane barter approach. Available from: http://www.gxdqw.com/bin/mse.exe?seachword=\&K=a\&A=41\&rec=140\&run=13 [in Chinese]

Guangxi Government, 2002. Regulations on management of sugarcane areas in Guangxi Zhuang Autonomous Region. Available from: http://www.gxgg.gov.cn/news/201512/106170.htm [In Chinese]

Guangxi Government, 2013. Opinions of the People's Government of Guangxi Zhuang Region on promoting sustainable development of the Autonomous Regional sugar industry [No. 36]. Accessible from: http://www.gxzf.gov.cn/zwgk/zfwj/zzqrmzfwj/201309/t20130906 424629.htm [in Chinese]

Guangxi Government, 2014. Notice of the People's Government of Guangxi Zhuang Autonomy Region on the implement plan of pilot construction of high-yield and high sugar content sugarcane production base [No. 15]. Accessible from: 
http://www.gxzf.gov.cn/zwgk/zfwj/zzqrmzfbgtwj/2014ngzbwj/201402/t20140217_428844.ht $\underline{\mathrm{m}}$ [In Chinese]

Guangxi government, 2014. Notice of the People's Government of Guangxi Zhuang Autonomy Region on the implementation plan of the high-yield and high-sugar-content cane production base construction [No.89]. Accessible from: http://www.gxzf.gov.cn/zwgk/zfgb/2015zfgb/2015 gb 09/2013 zfbgwj gb 2013/201410/t20 141009 443083.htm [In Chinese]

Guangxi Government, 2015. Notice of the People's Government of Guangxi Zhuang Autonomy Region on the implement plan of construction of high-yield and high sugar content sugarcane production base. Accessible from:

http://www.gxny.gov.cn/sgjd/tzgg/201511/t20151125 464791.html [In Chinese]

Guangxi Nanning East Asia Sugar Group Baidu Baike. Available from: http://baike.baidu.com/link?url=mBV2OXyBHSi5YcYF9naQKL1zWmsLyW2HM0myj2CVlHdzaZvrOrPkvUOy895JSegt 15eYbRTx7SiGU0EepG8a [in Chinese] [accessed on $26^{\text {th }}$ July 2016]

Guangxi Nanning East Asia Sugar Group website. Available from:

http://www.easugar.com/en/about_1.php [accessed on 26 ${ }^{\text {th }}$ July 2016]

Guangxi Nanning East Asia Sugar Group website: http://www.easugar.com/en/about_1.php [in Chinese] [accessed on $10^{\text {th }}$ April 2018]

Guangxi Planed Economic and Trade Commission, 2002. Notice of the People's Government of Guangxi Zhuang Region on rules for the implementation on sugarcane regulation inside the Autonomous Region [No. 560]. Accessible from:

http://www.1633.com/policy/html/guangxi/gongxinwei/2012/0316/278001.html [In Chinese]

Guangxi Price Bureau, 2014. Emergency notification on sugarcane purchasing price issue in 2014/15. Available from: http://news.static.gsmn.cn/201412/03/106.000043.B7A2.html [In Chinese] [accessed on 28th July 2016]

Guangxi Science and Technology Department. n. d. Sugarcane variety database. Available from: http://www.gxaas.net/NavaImageListMore.aspx?CatalogId=31\&CatalogItem=1 [In Chinese] [accessed on $20^{\text {th }}$ June 2017]

Guérin, I. 2013. Bonded labour, agrarian changes and capitalism: emerging patterns in South India. Journal of Agrarian Change, 13(3), pp.405-423.

Guo, X., Mroz, T. A., Popkin, B. M., Zhai, F., 2000. Structural change in the impact of income on food consumption in China, 1989-1993. Economic Development and Cultural Change, 48(4), pp.737-760.

Hall, R., 2011. Land grabbing in Southern Africa: the many faces of the investor rush. Review of African political economy, 38(128), pp.193-214.

Harvey, D. 2003. The new imperialism. New York: Oxford University Press.

Harvey, D. 2007. A brief history of neoliberalism. New York: Oxford University Press. 
He, X. F. and Liu, J., 2009. Reflection on the contract period of rural land. Social Sciences in Guangdong, (4), pp.153-157. [in Chinese]

He, X. F. and Liu, Z. J., 2010. Why Land Becomes a Right of Farmers [J]. Journal of China Agricultural University (Social Sciences Edition), (1), pp.19-28. [in Chinese]

He, X. F., 2012. The facts and understandings of land issues. Journal of China Agricultural University (Social Sciences Edition), (2), pp.1-19. [in Chinese]

He, X. F., 2014. The analysis on the potential problems of industrial and commercial capital going to the countryside. The Rural Discovery in China, (3), pp.125-131.

Ho, P., 2005. Institutions in transition: land ownership, property rights, and social conflict in China. Oxford University Press.

Hofman, I. and Ho, P., 2012. China's 'Developmental Outsourcing': A critical examination of Chinese global 'land grabs' discourse. Journal of Peasant Studies, 39(1), pp.1-48.

Hsu, H.H., Chern, W.S. and Gale, F., 2001. How will rising income affect the structure of food demand?. China's food and agriculture: issues for the 21st century, pp.10-13.

$\mathrm{Hu}, \mathrm{W} ., 1997$. Household land tenure reform in China: its impact on farming land use and agro-environment. Land Use Policy, 14(3), pp.175-186.

$\mathrm{Hu}$, X. D., 2008. Privatization of rural land: significance, problems and measures. China Rural Discovery. Available from: http://www.zgxcfx.com/Article/5904.html [accessed on 30th Jan. 2018] [in Chinese]

Huang, J. Y., Wu, J. M., Tang, S. Y., Li, X., Luo, Y. W. and Wang, L. W. 2016. Character performance and preliminary evaluation of 22 sugarcane varieties in Guangxi. Subtropical Agriculture Research, 2016, 12 (1), pp.1-7.

Huang, J., Li, N., \& Rozelle, S., 2003. Trade reform, household effects, and poverty in rural China. American Journal of Agricultural Economics, 85(5), pp.1292-1298.

Huang, J., Rozelle, S., \& Chang, M., 2004. The Nature of Distortions to Agricultural Incentives in China and Implications of WTO Accession. In China and the WTO: Accession, Policy Reform and Poverty Reduction Strategies, D. Bhattasali, S. Li, and W. Martin.

Huang, J., Yang, J., Zhigang, X. U., Rozelle, S., \& Ninghui, L. I., 2007. Agricultural trade liberalization and poverty in China. China Economic Review,18(3), pp.244-265.

Huang, P. C. 2010. China's Hidden Agricultural Revolution (zhongguo de yinxing nongye geming). Rural China, 8(1), pp.1-10.

Huang, P. C., Yuan, G., \& Peng, Y. 2012. Capitalization without proletarianization in China's agricultural development. Modern China, 38(2), pp.139-173. 
Huang, P.C., 2011. China's new-age small farms and their vertical integration: agribusiness or co-ops?. Modern China, 37(2), pp.107-134.

Huang, Z. Z., 2012. Introduction on "China's new era of small-scale peasant economy". Open Times, (3). http://www.opentimes.cn/bencandy.php?fid=332\&aid=1579 [in Chinese]

Huang, Z. Z., 2014. Is "family farms" the way to develop Chinese agriculture?. Open Times, (2). http://www.opentimes.cn/Abstract/1947.html [in Chinese]

Huang, Z. Z., 2014. Is "family farms" the way to develop Chinese agriculture? Open Times, (2). http://www.opentimes.cn/Abstract/1947.html [in Chinese]

Huang, Z.Z., 2010. China's hidden agricultural revolution. Beijing: Law Press. [in Chinese] Huanqiu Website, 2012. Organization modalities of agricultural industrialized operation. Available from: http://finance.huanqiu.com/mba/2012-08/3048672_3.html [in Chinese] [accessed on $9^{\text {th }}$ August 2016]

Ito, J., Bao, Z. and Su, Q., 2012. Distributional effects of agricultural cooperatives in China: Exclusion of smallholders and potential gains on participation. Food policy, 37(6), pp.700709.

Jia, X. P., Huang, J. K. and Xu, Z. G., 2012. Marketing of farmer professional cooperatives in the wave of transformed agrofood market in China. China economic review, 23(3), pp.665674.

Jiao, J., 2012. Revelations on the breakthrough of Guangxi sugar industry. Caijing Magazine. Available from: http://misc.caijing.com.cn/chargeFullNews.jsp?id=112291735\&time=2012$\underline{11-18 \& \mathrm{cl}=106}$ [in Chinese]

Johnson, C., 1990. The developmental state: Odyssey of a concept. In Woo-Cumings, Meredith (ed.) The Developmental State. Cornell: Cornell university Press.

Kaiwen, F., 2004. A Study on the outline history of the household responsibility system in rural China since 1949: The organizations, institutions, and their Changes. African and Asian Studies, 3(3-4), pp.219-244.

Kautsky, K., 1988. The agrarian question, 2 vols. Winchester, Mass.: Zwan.

Kawagoe, T., Hayami, Y. and Ruttan, V.W., 1985. The intercountry agricultural production function and productivity differences among countries. Journal of Development economics, 19(1-2), pp.113-132.

Keliang, Z. and Prosterman, R., 2007. Securing land rights for Chinese farmers: a leap forward for stability and growth. Cato Development Policy Analysis Series, (3).

Kenney, M., 1986. Biotechnology: The university-industrial complex. New Haven: Yale University Press.

Kloppenburg, J.R., 1988. First the seed: The political economy of plant biotechnology. Cambridge: Cambridge University Press. 
Lenin, V.I., 1982. The differentiation of the peasantry. Rural Development: Theories of Peasant Economy and Agrarian Change, ed. John Harriss. London: Routledge.

Lerche, J. 1995. Is bonded labour a bound category? Reconceptualising agrarian conflict in India. The Journal of Peasant Studies, 22(3), pp.484-515.

Lerche, J. 2011. The unfree labour category and unfree labour estimates: A continuum within low-end labour relations.

Li, Y. N, 2012. Hopes rise for the double-way of rural-urban integration. Beijing Daily. Available from: http://theory.people.com.cn/n/2012/1112/c40531-19551177-1.html [in Chinese] [accessed on $4^{\text {th }}$ Oct. 2016]

Li, G., Rozelle, S. and Brandt, L., 1998. Tenure, land rights, and farmer investment incentives in China. Agricultural Economics, 19(1-2), pp.63-71.

Li, S.C., 2013. COFCO took over Tully Sugar, bet on its 'sugar industry dream'. Financial and Economic Website. Available from: http://stock.caijing.com.cn/2013-0415/112674840.html [in Chinese] [accessed on 29 ${ }^{\text {th }}$ August 2016]

Lin Y., 2014. The total of rural cooperatives in China closes to one million. Economic Information, Available from: http://jjckb.xinhuanet.com/2014-02/22/content 492636.htm [in Chinese] [accessed on $9^{\text {th }}$ August 2016]

Lin, J. Y., Cai, F., \& Li, Z., 1998. Competition, policy burdens, and state-owned enterprise reform. The American Economic Review, 88(2), 422-427.

Lin, J. Y., 1992. Rural reforms and agricultural growth in China. The American economic review, pp.34-51.

Lin, X., 2014. COFCO and Noble discuss on a joint venture. Foods1 Website. Available from: http://www.foods1.com/content/2496174/ [in Chinese] [accessed on 29 ${ }^{\text {th }}$ August 2016] Lipton, M., 1977. Why poor people stay poor: a study of urban bias in world development. London: Canberra: Temple Smith; Australian National University Press.

Lipton, M., 1993. Land reform as commenced business: The evidence against stopping. World Development, 21(4), pp.641-657.

Liu, H. and Ye. Z., 2010. The historical review and current predicament study on rural land institution. Truth Seeking, (2), pp.86-89.

Liu, J. P., 2012. A research of China's rural land system and reform. Journal of Hainan University (Humanities \& Social Sciences), 30(1), pp.90-98.

Liu, L. S., 2010. Practice of Rural Cooperatives and Local Evaluation Criterion. Open Times, (12), pp.53-67. [in Chinese]

Lu F., 2012. The trends of wage change of Chinese migrant workers: 1979-2010. Social Science in China, pp.47-67. 
Lu, X. Y., 2005. Rural China needs second reform to further break the constraints of the planned economic institution for farmers. People's Daily. Available from: http://the ory.people.com.cn/GB/40764/55706/55707/3880135.html [in Chinese] [accessed on 31st Jan. 2018]

Luo, K., 2009. Sixty years of historical retrospect and the future prospects on Chinese sugar industry. Guangxi Sugarcane \&Cane sugar, (3), pp.45-48. [in Chinese]

Ma, L.P., 2012. Wen Tiejun: Agricultural production sector shows up excessive industrial capital. China Business Journal, Available from:

http://www.farmer.com.cn/xwpd/jjsn/201212/t20121217_785757.htm [in Chinese] [accessed on $14^{\text {th }}$ August 2016]

Ma, X., Heerink, N., Feng, S. and Shi, X., 2015. Farmland tenure in China: Comparing legal, actual and perceived security. Land Use Policy, 42, pp.293-306.

Mackenzie, D., 2008. The 21st-century land grab. New Scientist, 200, pp.8-9.

Makki, F., 2012. Power and property: commercialization, enclosures, and the transformation of agrarian relations in Ethiopia. Journal of Peasant Studies, 39(1), pp.81-104.

Marx, K. 1976. Capital: A Critique of Political Economy. The process of production of capital (Vol. 1). Progress.

McGrath, S. 2013. Fuelling global production networks with slave labour?: Migrant sugar cane workers in the Brazilian ethanol GPN. Geoforum, 44, pp.32-43.

McKay, B., Sauer, S., Richardson, B. and Herre, R., 2016. The political economy of sugarcane flexing: initial insights from Brazil, Southern Africa and Cambodia. The Journal of Peasant Studies, 43(1), pp.195-223.

McMichael, P., 2011. Food system sustainability: Questions of environmental governance in the new world (dis) order. Global Environmental Change, 21(3), pp.804-812.

McMichael, P., 2012. Depeasantization. The Wiley-Blackwell Encyclopedia of Globalization. https://doi.org/10.1002/9780470670590.wbeog140

McMichael, P., 2013. Land grabbing as security mercantilism in international relations. Globalizations, 10(1), pp.47-64.

McMichael, P., 2013. Food regimes and agrarian questions. Nova Scotia: Fernwood Publishing.

Ministry of Agriculture of China, 2016. National Planting Structure Adjustment Plan (20162020). Available from: http://www.moa.gov.cn/zwllm/zwdt/201604/t20160428_5112250.htm [in Chinese]

Ministry of Agriculture of the PRC., 2014. Sugar should enjoy the equal treatment of the strategic goods as grain-cotton-oil. Available from: 
http://www.moa.gov.cn/fwllm/qgxxlb/gx/201403/t20140311_3810755.htm [in Chinese] [accessed on 31st March 2017]

Ministry of Commerce, China., 2006. Law of the People's Republic of China on Specialized Farmers Cooperatives. Available from:

http://www.fdi.gov.cn/1800000121_23_61763_0_7.html [in Chinese] [accessed on $9^{\text {th }}$ Sept. 2016]

Ministry of Commerce, PRC., 2016. MOFCOM to Launch Investigation against the Safeguards of Imported Sugar. Available from:

http://english.mofcom.gov.cn/article/newsrelease/significantnews/201609/20160901403609.s $\underline{\text { html }}$ [accessed on 12th April, 2017]

Murphy, R. 2000. Return migration, entrepreneurship and local state corporatism in rural China: the experience of two counties in south Jiangxi. Journal of contemporary China, 9(24), 231247.

Murphy, S., Burch, D. and Clapp, J., 2012. Cereal secrets: The world's largest grain traders and global agriculture. Oxfam Research Reports.

National Bureau of Statistic of China, 2014. Compendium of source materials from the national survey of costs-incomes of agricultural products [abbr. CSMNSCIAP]. Beijing, China Statistics Press.

National Bureau of Statistics of China, 2009. Analysis on the situation of rural land transfer in Fujian Province. Available from:

http://www.stats.gov.cn/ztjc/ztfx/dfxx/200907/t20090701 34848.html [in Chinese] [accessed on 18 Sept. 2016]

National Bureau of Statistics of China, 2014. Research on the price relations of main agricultural products during production, distribution and consumption. Available from: http://www.stats.gov.cn/tjzs/tjsj/tjcb/dysj/201406/t20140612_567159.html [in Chinese] [accessed on $6^{\text {th }}$ Sept. 2016]

National Bureau of Statistics of China, 2016. Facilitate land transfer and promote working on 'three rural issues'. Available from:

http://www.stats.gov.cn/ztjc/ztfx/dfxx/201012/t20101227_35288.html [in Chinese] [accessed on $18^{\text {th }}$ Sept. 2016]

National Bureau of Statistics of China. http://www.stats.gov.cn/english/

National Bureau of Statistics of China., 2016. Domestic food supply and the trend forecast of 'Thirteenth Five' Period. Available from:

http://www.stats.gov.cn/tjzs/tjsj/tjcb/dysj/201503/t20150313_693961.html [in Chinese] [accessed on $4^{\text {th }}$ Sept. 2016]

National Development and Reform Commission, 2015. Development Plan for the Main Sugarcane Producing Area (2015-2020). Official document can be downloaded from: http://www.sdpc.gov.cn/zcfb/zcfbtz/201506/t20150604_694957.html [in Chinese] 
National Development and Reform Commission, 2015. Development Plan for the Main Sugarcane Producing Area (2015-2020). Available from:

http://www.sdpc.gov.cn/zcfb/zcfbtz/201506/W020150604323728878521.pdf [in Chinese] [accessed on $31^{\text {st }}$ March 2017]

North, D.C., 1991. Institutions. Journal of economic perspectives, 5(1), pp.97-112.

Oi, J. C. 1992. Fiscal reform and the economic foundations of local state corporatism in China. World Politics, 45(1), pp.99-126.

Oliveira, G.D.L. and Schneider, M., 2016. The politics of flexing soybeans: China, Brazil and global agroindustrial restructuring. The Journal of Peasant Studies, 43(1), pp.167-194.

Output Value and Income Database. Provided by Department of Crop Farming Administration, Ministry of Agriculture of China. Available from: http://202.127.42.157/moazzys/nongqing_xm.aspx [in Chinese] [accessed on 20 $0^{\text {st }}$ March 2017]

Oya, C., 2013. Methodological reflections on 'land grab' databases and the 'land grab' literature 'rush'. Journal of Peasant Studies, 40(3), pp.503-520.

Paprocki, K., 2013. Selling our own Skin: Microcredit, depeasantization and social dispossession in rural bangladesh. https://hdl.handle.net/1813/34115

Prosterman, R.L., Hanstad, T. and Ping, L., 1996. Can China feed itself?. Scientific American, 275(5), pp.90-96.

Qiao, J. L., 2013. The number of family farms in China up to 877,000. China Economics Website. Available from:

http://www.ce.cn/macro/more/201306/05/t20130605_24449905.shtml [in Chinese] [accessed on $25^{\text {th }}$ August 2016]

QStheory, 2015. Analysis of China's food security and supply-demand condition. Available from: http://www.qstheory.cn/economy/2015-02/15/c_1114379549.htm [accessed on 30th March 2017] [in Chinese]

Ragin, C.C. and Becker, H.S. eds., 1992. What is a case?: exploring the foundations of social inquiry. Cambridge university press.

Rao, J. M. 1988. Fragmented rural labour markets. The Journal of Peasant Studies, 15(2), pp.238-257.

Reuters news, 2014. China to launch new registration system for sugar imports. Available from: http://economictimes.indiatimes.com/news/international/business/china-to-launch-newregistration-system-for-sugar-imports/articleshow/44968559.cms [accessed on $12^{\text {th }}$ April 2017]

Ritzer, G. and Ryan, J.M. eds., 2010. The concise encyclopedia of sociology. Hoboken (New Jersey): John Wiley \& Sons. 
Robertson, B. and Pinstrup-Andersen, P., 2010. Global land acquisition: neo-colonialism or development opportunity?. Food Security, 2(3), pp.271-283.

Rozelle, S., Huang, J. and Zhang, L., 2002. Emerging markets, evolving institutions, and the new opportunities for growth in China's rural economy. China Economic Review, 13(4), pp.345-353.

Sanderson, S., 1986. The emergence of the'world steer': internationalization and foreign domination in Latin American cattle production. Food, the state and international political economy, pp.123-148.

Sargeson, S., 2004. Full circle? Rural land reforms in globalizing China. Critical Asian Studies, 36(4), pp.637-656.

Schneider, M., 2017. Dragon head enterprises and the state of agribusiness in China. Journal of Agrarian Change, 17(1), pp.3-21.

Scoones, I., Hall, R., Borras, S.M., White, B. and Wolford, W., 2013. The politics of evidence: methodologies for understanding the global land rush. The Journal of Peasant Studies, 40(3), pp.469-483.

Scott, J.C. 1977. The moral economy of the peasant: Rebellion and subsistence in Southeast Asia. Yale University Press.

Scott, J.C., 1972. Patron-client politics and political change in Southeast Asia. American political science review, 66(1), pp.91-113.

Sdnews, 2013. Scaled-up land turns to growing economic crops or tourism, the "non-grain oriented risk' of land transfer. Available from:

http://f.sdnews.com.cn/sdcj/201404/t20140423_1589738.htm [in Chinese] [accessed on $2^{\text {nd }}$ Oct. 2016]

Shen, M., Rozelle, S., Zhang, L. and Huang, J., 2005. Farmer's professional associations in rural China: State dominated or new state-society partnerships. China's agricultural and rural development in the early 21 st century. Australian Centre for International Agricultural Research, pp.197-228.

Shiva, V., 2000. Stolen harvest: The hijacking of the global food supply. London: Zed Books.

Si, W., 2004. The retrospect and prospect of sugar industry development in China. World Agriculture, (03), pp.10-13.

Singh, S. and Bhogal, S., 2014. Depeasantization in Punjab: status of farmers who left farming. Current Science, pp.1364-1368.

SJZnews, 2015. High land transfer cost challenges the grain farmers. Available from: http://www.sjzdaily.com.cn/finance/2015-04/09/content_2398451.htm [in Chinese] [accessed on $9^{\text {th }}$ Oct. 2016] 
Snipstal, B., 2015. Repeasantization, agroecology and the tactics of food sovereignty. Canadian Food Studies/La Revue canadienne des études sur l'alimentation, 2(2), pp.164-173.

Soiffer, S.M. and Howe, G.N. 1982. Patrons, clients and the articulation of modes of production: an examination of the penetration of capitalism into peripheral agriculture in Northeastern Brazil. The Journal of Peasant Studies, 9(2), pp.176-206.

Sommerville, M., Essex, J. and Le Billon, P., 2014. The 'global food crisis' and the geopolitics of food security. Geopolitics, 19(2), pp.239-265.

State Council, 1981. Notice on the grain reward issues in grain-cotton barter, grain-sugar barter policies. Available from: http://www.chinalawedu.com/falvfagui/fg22016/12078.shtml [in Chinese]

Sun, H.L., 2011. Understanding China's agricultural investments in Africa. Johannesburg: The South African Institute of International Affairs.

Sun, X. H. 2015. The emergence of large-scale agricultural management subjects and the radical agricultural transformation - the case of Wan nan he town. Open times, (5). http://www.opentimes.cn/bencandy.php?fid=399\&aid=1920 [in Chinese]

Tao, R. and Xu, Z., 2007. Urbanization, rural land system and social security for migrants in China. The Journal of Development Studies, 43(7), pp.1301-1320.

Taylor, E. J. 1999. The new economics of labour migration and the role of remittances in the migration process. International migration, 37(1), pp.63-88.

Taylor, J. E., Rozelle, S., \& De Brauw, A. 2003. Migration and incomes in source communities: A new economics of migration perspective from China. Economic Development and Cultural Change, 52(1), pp.75-101.

The Poultry Site, 2014. China's food self-sufficiency policy. Available from: https://www.google.nl/webhp?sourceid=chrome-instant\&ion=1\&espv=2\&ie=UTF-

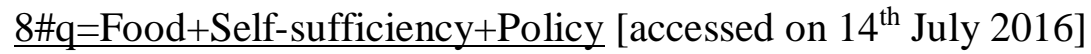

Thematic Database for Human-earth System. http://www.data.ac.cn/index.asp [in Chinese] [accessed on $15^{\text {th }}$ July 2016]

Tu, J., 2014. A study on agricultural production modes after capital-led land transfer. MA thesis, China Agricultural University, Beijing. [in Chinese]

Van der Ploeg, J. D. 2009. The new peasantries: struggles for autonomy and sustainability in an era of empire and globalization. London: Routledge.

Van der Ploeg, J.D. and Ye, J. eds., 2016. China's Peasant Agriculture and Rural Society: Changing Paradigms of Farming. London and New York: Routledge.

Van der Ploeg, J.D., 2012. The new peasantries: struggles for autonomy and sustainability in an era of empire and globalization. Routledge. 
Van der Ploeg, J.D., 2013. Peasants and the art of farming: A Chayanovian manifesto (No. 2). Nova Stotia: Fernwood.

Vartanian, T. P. 2010. Secondary data analysis. Oxford: Oxford University Press.

Vià, E.D., 2012. Seed Diversity, Farmers' Rights, and the Politics of

Repeasantization. International Journal of Sociology of Agriculture \& Food, 19(2).

Von Braun, J. and Meinzen-Dick, R.S., 2009. Land grabbing" by foreign investors in developing countries: risks and opportunities. Washington, DC: International Food Policy Research Institute.

Von Braun, J., 2008. Food and financial crises: Implications for agriculture and the poor (Vol. 20). Washington, D.C.: International Food Policy Research Institute.

Wang, H., Riedinger, J. and Jin, S., 2015. Land documents, tenure security and land rental development: Panel evidence from China. China Economic Review, 36, pp.220-235.

Wang, H., Tong, J., Su, F., Wei, G. and Tao, R., 2011. To reallocate or not: Reconsidering the dilemma in China's agricultural land tenure policy. Land Use Policy, 28(4), pp.805-814.

Wang, J., Wailes, E.J. and Cramer, G.L., 1996. A shadow-price frontier measurement of profit efficiency in Chinese agriculture. American Journal of Agricultural Economics, 78(1), pp.146-156.

Wang, L.X., 2009. Theory and Reality of Agrarian Capitalist: agricultural development in Punjab of India during Green Revolution. Social Sciences in China, (5): pp.189-203. [in Chinese]

Wang, Q. and Zhang, X., 2017. Three rights separation: China's proposed rural land rights reform and four types of local trials. Land Use Policy, 63, pp.111-121.

Wen, T. 2011. Comprehensive cooperative economic organization is the development trend. China Co-operation Economy, (1), pp.29-30. [in Chinese]

Wen, T. J., 2008. The bottom line of rural policies is no privatization. Studies on the socialism with Chinese characteristics, (3), pp.110-111.

Wen, T. J., 2009. Why privatization of land property cannot be implemented in China?. Redflag Manuscript, (2), pp.15-17.

Wolf, E.R. 1969. Peasant wars of the twentieth century. University of Oklahoma Press.

Wong, C.P., 2000. Central-local relations revisited the 1994 tax-sharing reform and public expenditure management in China. China Perspectives, pp.52-63.

Worby, E. 1995. What does agrarian wage-labour signify? Cotton, commoditisation and social form in Gokwe, Zimbabwe. The Journal of Peasant Studies, 23(1), pp.1-29. 
World Bank, 2014. China economic update. Available from:

https://www.worldbank.org/content/dam/Worldbank/document/EAP/China/China_Economic _Update_June2014.pdf [accessed on $4^{\text {th }}$ April 2018]

World Trade Organization, 2011. China and the WTO. Available from: https://www.wt o.org/english/thewto_e/countries_e/china_e.htm [accessed on 15 ${ }^{\text {th }}$ April 2017]

Xu, G. X., 2007. The development of Guangxi sugarcane production in the Republic of China era. Guangxi Sugarcane \& Cane sugar, (4), pp.50-53. [in Chinese]

Xu, X., Qi, G. and Li, X., 2014. Business Borderlands: China's Overseas State Agribusiness. IDS Bulletin, 45(4), pp.114-124.

$\mathrm{Xu}, \mathrm{Y} ., 2018$. Political economy of land grabbing inside China involving foreign investors. Third World Quarterly, pp.1-16.

Yan H. R., Chen Y. Y., 2015. Agrarian capitalization without capitalism? Capitalist dynamics from above and below in China. Journal of Agrarian Change, 15(3), pp.366-391.

Yan, H. R, Chen, Y. Y. and Bun, K. H., 2016. China's soybean crisis: the logic of modernization and its discontents. The Journal of Peasant Studies, 43(2), pp.373-395.

Yan, H. R. and Chen, Y. Y., 2013. Debating the rural cooperative movement in China, the past and the present. Journal of Peasant Studies, 40(6), pp.955-981.

Yang, X., 1993. Theories of property rights and China's reforms. China Economic Review, 4(2), pp.195-212.

Ye, J. and Pan, L., 2016. Concepts and realities of family farming in Asia and the Pacific (No. 139). Working Paper, International Policy Centre for Inclusive Growth.

Ye, J., 2015. Land Transfer and the Pursuit of Agricultural Modernization in C hina. Journal of agrarian change, 15(3), pp.314-337.

Ynsugarnet. 2007. The history of "east sugar going west" in China. http://www.ynsugar.com/Article/TYZL/200705/3115.html [in Chinese] [accessed on $29^{\text {th }}$ August 2017]

Yu, H., Huang, J. K., Rozelle, S. and Brandt, L., 2003. Impact of the socio-economic factors on soil fertility over time. Resources Science, 25 (2), pp. 63-72.

Yunnan Sugar Web, 2014. China Sugar Association organized the symposium with sugar refineries. Available from: http://www.ynsugar.com/Article/HuiX/201404/42290.html [in Chinese] [accessed on $12^{\text {th }}$ April 2017]

Yunnan website, 2009. Bright Food acquired 60\% stake of Yunnan Yingmao Sugar company. Available from: http://finance.yunnan.cn/html/2009-08/19/content 876476.htm [in Chinese] [accessed on $11^{\text {th }}$ May 2017] 
Zhan, S., 2015. From Local State Corporatism to Land Revenue Regime: Urbanization and the Recent Transition of Rural Industry in China. Journal of Agrarian Change, 15(3), pp.413-432.

Zhang, L. L., 2013. Land transfer sped up and land price increased in Anhui Province in the last decade. China Economic Herald. Available from:

http://www.ceh.com.cn/shpd/2013/12/280902.shtml [in Chinese] [accessed on $17^{\text {th }}$ Sept. 2016]

Zhang, C. and Clovis, J., 2010. China inflation dynamics: Persistence and policy regimes. Journal of Policy Modeling, 32(3), pp.373-388.

Zhang, J., 2016. Getting the data right: main trends in China's agriculture and food sector.

Beijing: the $4^{\text {th }}$ BICAS Conference The full paper can be accessed through:

http://cohd.cau.edu.cn/bicas/12-BICAS-CP-Zhang-Jin.pdf

Zhang, J., 2017. Agrarian change and the pursuit of self-supplied food security in China. The conference paper is presented in ICAS-Etxalde Colloquium - Elikadura21. The full paper is accessible from: http://elikadura21.eus/wp-content/uploads/2017/04/68-Zhang.pdf

Zhang, Q. F. and Donaldson, J. A., 2010. From peasants to farmers: Peasant differentiation, labor regimes, and land-rights institutions in China's agrarian transition, Politics \& Society, 38(4), pp. 458-489.

Zhang, Q. F. and Donaldson, J.A., 2013. China's Agrarian Reform and the Privatization of Land: a contrarian view. Journal of contemporary China, 22(80), pp.255-272.

Zhang, Q .F., 2015. Class Differentiation in Rural China: Dynamics of Accumulation, Commodification and State Intervention, Journal of Agrarian Change, 15(3), pp.338-365.

Zhang, W. M., 2015. Poverty reduction pace accelerating, remarkable achievement and a substantial reduction in poor population. Available from: http://www.stats.gov.cn/tjsj/sjjd/201510/t20151016_1257098.html [in Chinese] [accessed on $4^{\text {th }}$ April 2018]

Zhang, X. S., 2014. The normalization of development and trajectories of specialized farmers cooperatives. Journal of Hunan Agricultural University, (142), pp.25-26.

Zhonghua, S., Hanya, L. and Kun, Z., 2010. The investigation report on the development of land shareholding cooperatives in Jiangsu Province. Issues in Agricultural Economy, (8), pp.30-35.

Zoomers, A., 2010. Globalisation and the foreignisation of space: seven processes driving the current global land grab. The Journal of Peasant Studies, 37(2), pp.429-447. 


\section{Summary}

Food security is a critical issue. There are different policies and projects designed and applied to achieve food security in many countries. However, whether these policies and projects are feasible and effective are dependent on local conditions on natural resources and socioeconomic relations. This research aims to evaluate the sugarcane intervention project for sugar supply security in China, more importantly, to examine the agrarian change that resulted from the interaction between sugarcane intervention project and dynamics in Chinese peasant farming. The analytical framework combines rural sociology and political economic perspectives. The research contains five specific research questions that are addressed through macro-level political economic analysis and micro-level sociological study. The research is of societal relevance as findings can contribute to academic debates in agrarian studies and policy development on designing food security projects.

The fast urbanisation in China has multiple impacts on its domestic agriculture and food sector. First, it causes the massive rural-urban migration inside China, where rural labour is continuously absorbed by manufacturing and service industries in urban China. Second, income increase among Chinese citizens (especially urban citizens) led to a structural change of diet, that is, Chinese citizens consume more high-value food products such as meat, fruits, dairy products, aquatic products, nuts leading to a lower demand for low-value grain products. Third, the rural-urban development inequality drove the Chinese government to stimulate industrial and commercial capital to invest in countryside and agricultural production. Furthermore, China's access to WTO forced the domestic agricultural and food sector to be open to the global market.

Given these factors influencing China's agriculture and food sector, the thesis first tries to provide a clear overview of the present situation, that is, what is exactly the current systematic situation of China's agriculture and food sector? Chapter 2 examines this question from three dimensions: domestic agricultural production, food consumption inside China, and agricultural trade between China and the global market. It shows that the agricultural production in China is not operated through one singular modality, instead, there are multiple modalities that can be observed in China's agricultural production, such as small-household farming, scaled-up family farming, cooperative farming, specialized farming companies and dragon-head enterprises. In terms of the agricultural output, there is a structural transition to producing more high-value products and less low-value products, which is partly result from the diet's structural change of Chinese people. The rapid increase in land rent and labour price in China is another important reason for the structural transition in agricultural output. The changes inside China's agriculture and food sector are further linked to China's oversea agricultural activities. The chapter shows that low-value non-grain crops are increasingly imported by China, but China exports more high-value agricultural products, such as vegetables, fruits, herbs, tea, etc. Thus, it is inaccurate to claim that China is a country suffering from food insecurity. This finding is contrary to literature arguing that China is a main player in global land rush in order to prevent food insecurity. 
The changes in China's agricultural production have reached the attention of policy makers in China. Consequently, the Chinese government launched several intervention projects aiming to protect domestic production of the low-value crops, mainly sugar crops, oil crops and cotton crop. Chapter 3 questions what dynamics would occur when the changes in Chinese agricultural production encounter the agricultural intervention projects. The chapter takes sugarcane production as a case. It first systematically studies the state intervention policies on sugarcane production over different time periods since the People's commune period. The purpose of this historical analysis is to show that the current intervention projects have different perceptions of the state on the future trajectory of agricultural production, the fate of peasant farming, and implications on food security. Focusing on rural society and peasant farming, the chapter shows that the sugarcane intervention project brought large capital external to the rural committees into the local sugarcane production activities. The emergence of capitalist sugarcane farms squeezes the social-economic conditions of rural society as a whole instead of differentiating Chinese peasants. Nevertheless, the peasants involved in the intervention project did make diverse economic choices. These choices were based on their accessible resources to and the market situation of land, labour and other production factors.

While Chapter 2 and Chapter 3 mainly discuss macro-level socio-economic changes, Chapter 4 to 6 focus on the micro-level dynamics in agricultural production and rural livelihoods. Chapter 4 examines the capital accumulation strategies in the sugarcane intervention project. The introduction of new techniques and technologies in agricultural production is mostly considered to be beneficial to peasants. However, this chapter shows that bringing in new techniques and technologies is a strategy of the sugar company to redistribute costs and benefits between cane peasants and the sugar company. Moreover, capital accumulation is not only an economic action, but also strongly related to political intervention. The politicization of the domestic sugar supply issue is aimed to restructure sugarcane production and the domestic sugar market for the accumulation purpose of the sugar companies. Another key point is that speculation activities should be given more attention in capital accumulation studies. The specialized farming company was set up to extract governmental subsidies for (supposed) sugarcane production rather than to conduct (actual) farming. Consequently, land is converted from a means of production into an object of speculation.

Sugarcane production has a high demand of labour, especially during the harvest season. Accordingly, labour migration has been a way to tackle the labour shortage issue in Guangxi sugarcane areas. Based on the fieldwork research, the history of three waves of cane-cutting migrants in Fusui County brought up the key question in Chapter 5: why did the previous canecutting peasants cease seasonal migration while the current cane-cutting peasants start selling labour? This chapter starts with the history of sugar industry shifting from southeast China to southwest China and shows that changing farming strategies of the southeast peasants facilitated the geographic shift of sugar industry. Meanwhile, peasants from southwest China stopped migrating to the manufacturing industry in southeast China as they caught up the market opportunity and started growing sugarcane. Consequently, a new labour market was created in the sugarcane areas in southwest China. Focusing on the seasonal migration of canecutters in Fusui County, the chapter shows that three waves of cane-cutting migration in Fusui County occurred, which is due to the fact that when labour-selling peasants obtained enough 
income to invest in their own farms or other rural production activities, they consequently refrained from migration. The current cane-cutters in Fusui County are largely north Vietnamese whose labour price is cheaper. The Chinese cane farmers and Vietnamese cane cutters form a patron-client employment relationship, which has multiple social, economic and cultural reasons. The most important reason is the complementary agrarian calendars between Chinese cane farmers and Vietnamese cane-cutting peasants.

Capital, labour and land are the three key factors of agricultural production. Having discussed capital accumulation and labour migration, Chapter 6 focuses on the rural land institutions in China, with particular attention on the new registration of rural land usufruct rights since 2013. The chapter starts with reviewing three approaches related to China's rural land tenure system: the privatization of the land tenure system, its nationalization, and the strengthening of the current Household-contract Responsibility System. The Chinese government is inclined to the third approach and accordingly introduced the policy of re-certifying rural land usufruct rights in rural China, which are actually the land contractual rights of rural households under the Household Responsibility System since the early 1980s. The chapter shows that the new registration of rural land usufruct rights not only failed to improve the current state of affairs characterized by ownership disputes and distribution conflicts within rural communities, but also created new problems related to large-scale land transfers to capital holders external to rural communities. Furthermore, the chapter explores the difference between capitalist concentrations and cooperatives in terms of land management and agricultural production. It argues that while the current land system has facilitated capitalist investment in agricultural production, the establishment of cooperatives might be a viable alternative way of scaling up agricultural production in China.

Chapter 7 discusses the main research findings and their significance in academic debate and policy design. It also includes reflections of this research and recommendation for the future research. This research, taking the sugarcane intervention project as a case, tries to reach a clearer understanding of the complexities of the state intervention in the agriculture and food sector, the dynamics of peasant farming and the interaction between the two processes in China. The main challenge in China's agriculture and food sector is the mismatch between the macrolevel food security strategy of the Chinese government and the micro-level farming-strategy changes of the Chinese peasants. With the state intervention, capitalist farming is rising in China's agricultural production, which can be destructive to peasant farming. The main limitations of this research are lack of statistical data, restriction of research time, and a limitation of generalising the research results. As the future research, it recommends to further explore possibilities of maintaining a sustainable system of food supply and consumption in China. Finally, the chapter reveals a methodological reflection in agrarian studies, that is, to combine actor-oriented studies with political-economic analysis. 


\section{Acknowledgment}

$\mathrm{PhD}$ is a long and not necessarily pleasant journey. It is not only about learning academic perspectives, creating new knowledge and publishing articles, but also about dealing with emotional challenges. During the four years, I had experienced loneliness, powerlessness, stress and frustration. Luckily, I was not beaten down by these negative emotions, but rather growing up into a real adult. For this turning, I am very grateful to all the supports I got during my $\mathrm{PhD}$ journey.

First of all, I would like to say many thanks to my (co)promoters, Prof. Jan Douwe Van der Ploeg, Prof. Saturnino Borras and Prof. Huifang Wu. Their trust on my academic ability is the most important support for me to finish my PhD. Prof. Van der Ploeg taught me to think dialectically, to write rigorously and to argue thoroughly in conducting academic work. However, personally I consider the life attitude he taught me is the most precious lesson. He taught me to be brave, persistent and kind. He also let me realize that life is an adventure and I should take actions to dive in the adventure. I learned from him how to express my needs in a direct way and how to resist the bureaucratic system in the world. Prof. Borras helped me to start my PhD in the International Institute of Social Studies (ISS), the Hague. After a year, he helped me to adjust my research plan and get in touch with Prof. Van der Ploeg. His sharp and key suggestions always direct me to find a solution in difficult times. I learned a lot from him about academic publishing and other skills, and more importantly, how to combine research and activities together. Prof. Wu gave me strong support for my fieldwork in Guangxi province and helped me to overcome the difficulties in $\mathrm{PhD}$ life. I take her as my respectful teacher as well as my close friend.

Then, I would like to express my earnest thanks to my two mentors. Prof. Jingzhong Ye gave me the strongest support during my shift from ISS to Wageningen University. I am very grateful to his efforts and care for me during the difficult time. Dr. Sabine De Rooij helped me in both academic life and emotional life. She taught me to be brave in breaking restrictions of traditional concepts and embracing love. Moreover, she also showed me through her stories about how to be an independent and interesting woman.

I am very grateful to meet some of my close friends during the $\mathrm{PhD}$ period. I have shared happiness and worries with them and they were always there for me. I cannot image how could I survive in the Netherlands without my friends. In Wageningen, Yu Hong, Tian Yu, Min Liu supported me in writing thesis, opening career choices and understanding life. In Erasmus University, the friendship with Cheng Bian, Zhihao Yang, Qiong Gong, Ziyu Liu, Fan Jia started immediately when I landed in the Netherlands. We have been supporting and caring each other during the journey of pursuing our $\mathrm{PhD}$ degrees in the Netherlands. In ISS, I got great supports from Rath Thuon, Elizabeth Swartz, Yunan Xu, Huei-Ling Lai, Lyu Zheng. We continued our "girls' meeting" regularly, sharing academic struggles and life choices.

Next, I would love to express my gratitude to the colleagues from ISS: Alberto Alonso-Fradejas, Ben McKay, Natalia Kalfics-Mamonova, Elyse Mills, Christina Schiavoni, Martha Robbins, Tsegagy Moreda Shegro. I also feel very lucky to meet my cute Dutch corridor mates in Asserpark. They are: Marijn Tijdens, Sven Verweij, Rik van Heumen, Janine de Wit, Ruben Imhoff and Marliek Heldens. Also, many thanks to my colleagues and friends in Wageningen: Evert Los, Shiela Chikulo, Hellen Kimanthi, Nikolas Henriquez. I am also happy to be in the 
social network of the Chinese PhD students in Leeuwenborch, including Jinhui Hao, Chen Qian, Kai Wang, Guangcheng Ren, Minjie Chen, Yan Jin and Fan Li. I also enjoyed the time spent with many other friends that I met in Wageningen, including Stan Jansen, Yibo Jiang, Ying Deng, Danlei Wang and many others that I am not going to name one by one here.

Last, but certainly the most, I am extremely grateful to my parents, my sister, my partner and the parents of my partner. I can get here today mainly because of their supports and understanding. My parents always give the best to me and I feel no way to pay back. My sister takes full care of my parents and without any complaint of me being away. My partner is the most tolerant man in the world, and I learnt a lot from him. The parents of my partner offered me the parental love and care in the Netherlands. I am so lucky to be a family member with you. I love you so much, always!

Jin Zhang

February, 2019 


\section{Biography}

Jin Zhang was born on the $16^{\text {th }}$ June 1990 in Yixian, Hebei province, China. She first completed her bachelor's degree with the major of 'teaching Chinese as a foreign language' in 2012 from Hebei University of Technology, Tianjin. After the bachelor study, she was recommended to pursue a master's degree in China Agricultural University, where she stepped into the field of 'rural development and management'.

In September 2014, Jin Zhang started her PhD research first with the Political Ecology Group at the International Institute of Social Studies (ISS), the Hague. Due to the change of research methodology, she shifted to the Rural Sociology Group at Wageningen University and Research (WUR) in July 2016. As part of the $\mathrm{PhD}$ training, she had followed various courses offered by both ISS and WUR. She presented her research at several international conferences, such as the Beijing and Moscow conferences of the BRICS Agrarian Studies, ICAS-Etxalde Colloquium, etc. She has been publishing some chapters from the $\mathrm{PhD}$ thesis, among which Chapter 2 was accepted by Journal of Contemporary China, and Chapter 4 was accepted by International Journal of Sociology of Agriculture and Food.

Jin Zhang' research interests include the agricultural production and food security issues, peasant farming and peasant livelihoods, agricultural capital investment, agricultural labour migration and land institutions. 
Jin Zhang

Wageningen School of Social Sciences (WASS)

Completed Training and Supervision Plan

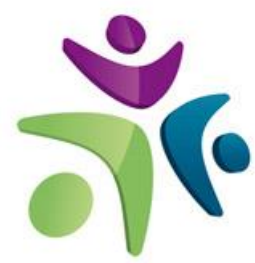

Wageningen School

of Social Sciences

\section{Name of the learning activity}

A) Project related competences

Global Environmental Politics

Politics of Agrarian Transformation

Institute of Social Studies

Institute of Social Studies

Political Economy of the Global Food Institute of Social Studies

System

Writing Research proposal

ISS, WUR

WASS

'WASS Introduction course China's Agriculture and Food sector'

'Agrarian Change and the Pursuit of self-supplied food security in China'

'Strategies underlying accumulation in agro-food sector :

capital The $5^{\text {th }}$ BRICS Agrarian Studies Conference, Moscow

Agro-technification, food politicization

and land speculation'

'Resisting, organising and mobilising for an The Emancipatory Rural Politics emancipatory rural politics' (round table Initiative, Den Haag discussion)

'The state, capital and peasantry in China's WASS PhD Day pursuit of food self-sufficiency'

'A discussion of rural land institutions in WASS PhD Day

China: the present and future'

\section{C) Career related competences/personal development}

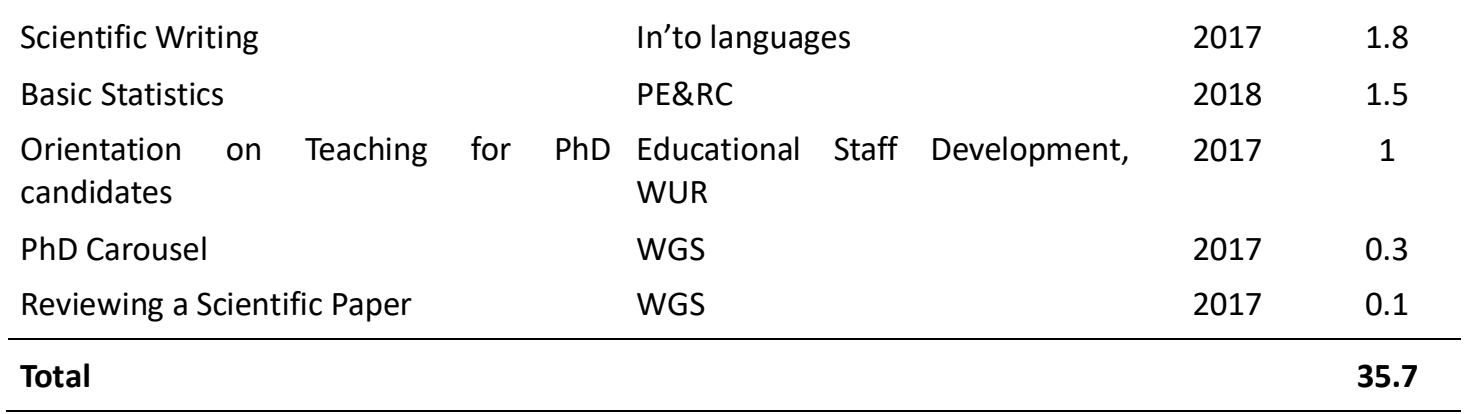

*One credit according to ECTS is on average equivalent to 28 hours of study load

$\begin{array}{ll}2015 & 6 \\ 2014 & 6 \\ 2015 & 6 \\ 2015 & 6\end{array}$

$2016 \quad 1$

20161

$2017 \quad 1$

$2017 \quad 1$

$2018 \quad 1$

$2017 \quad 1$

$2018 \quad 1$

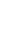




\section{Colophon}

This $\mathrm{PhD}$ program was financially supported by the China Scholarship Council (CSC), the College of Humanities and Development Studies in China Agricultural University (COHDCAU) and Wageningen School of Social Sciences (WASS).

The LEB Fund of Wageningen University financed my conference participation.

Printed by: Digiforce $\|$ ProefschriftMaken 